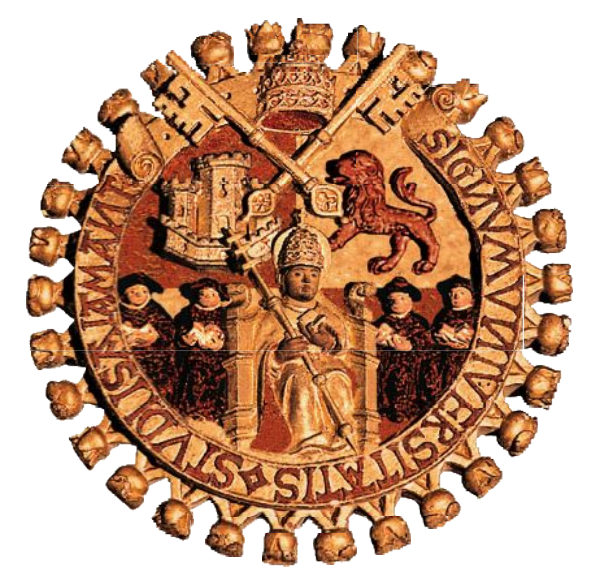

UNIVERSIDAD DE SALAMANCA

FACULTAD DE MEDICINA

\title{
ESTUDIO DE LOS POLIMORFISMOS DE GENES REPARADORES EN POBLACIÓN FUMADORA CON Y SIN CÁNCER DE PULMÓN
}

T E S I S D O C T O R A L

DIEGO SOTO DE PRADO OTERO

2008 


\author{
UNIVERSIDAD DE SALAMANCA \\ FACULTAD DE MEDICINA \\ DEPARTAMENTO DE MEDICINA, \\ UNIDAD DE MEDICINA MOLECULAR
}

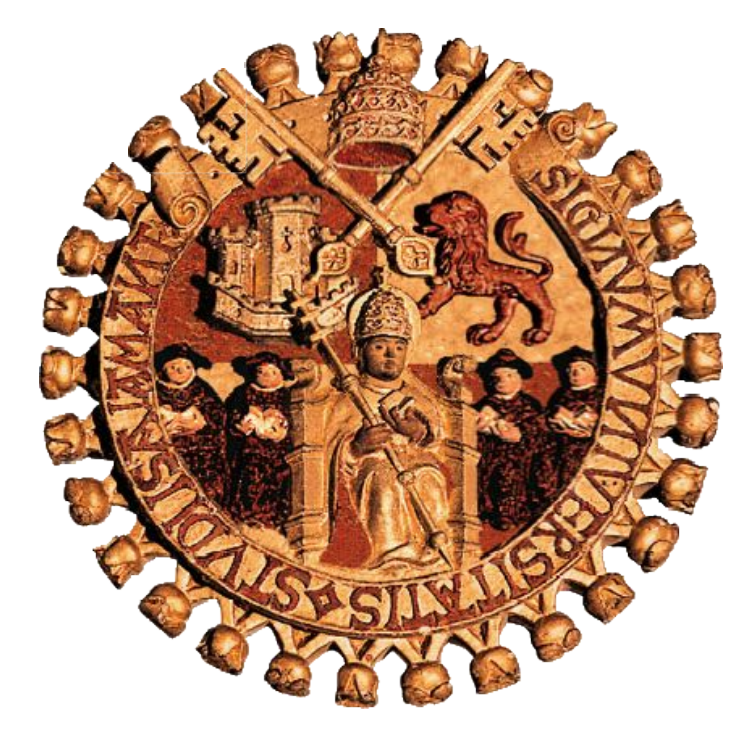

ESTUDIO DE LOS POLIMORFISMOS DE GENES REPARADORES EN POBLACIÓN FUMADORA CON Y SIN CANCER DE PULMÓN

Diega Sata de Prada Otera

2008 


\section{DIRECTORES:}

DR. D. JUAN JESUS CRUZ HERNANDEZ

CATEDRATICO DE UNIVERSIDAD. AREA DE CONOCINIMIENTO MEDICINA. DEPARTAMENTO DE MEDICINA. FACULTAD DE MEDICINA.

UNIVERSIDAD DE SALAMANCA

JEFE DE SERVICIO DE ONCOLOGÍA MÉDICA

HOSPITAL CLINICO UNIVERSITARIO DE SALAMANCA.

DR. D. ROGELIO GONZÁLEZ SARMIENTO

CATEDRATICO DE UNIVERSIDAD. AREA DE CONOCINIMIENTO MEDICINA. DEPARTAMENTO DE MEDICINA. FACULTAD DE MEDICINA.

UNIVERSIDAD DE SALAMANCA

SALAMANCA 2008. 
D. JUAN JESÚS CRUZ HERNÁNDEZ, CATEDRÁTICO DEL DEPARTAMENTO DE MEDICINA DE LA UNIVERSIDAD DE SALAMANCA

D. ROGELIO GONZÁLEZ SARMIENTO, CATEDRÁTICO DEL DEPARTAMENTO DE MEDICINA DE LA UNIVERSIDAD DE SALAMANCA

\section{CERTIFICAN:}

Que el trabajo titulado: "ESTUDIO DE LOS POLIMORFISMOS DE GENES REPARADORES EN POBLACIÓN FUMADORA CON Y SIN CÁNCER DE PULMÓN" que presenta el doctorando Diego Soto de Prado Otero, ha sido realizado bajo su dirección y reúne, a su juicio, todas las características necesarias, considerándolo apto para que sea presentado ante el tribunal correspondiente, a fin de optar al grado de Doctor por la Universidad de Salamanca.

Para que conste, y a los efectos oportunos, expiden el presente certificado en Salamanca, a 26 de mayo, de 2008.

Juan Jesús Cruz Hernández

Rogelio González Sarmiento 
Este trabajo de tesis doctoral ha sido financiado en parte por la "Asociación para el desarrollo de la Oncología Médica” del Servicio de Oncología del Hospital Clínico Universitario de Salamanca.

En el trabajo estadístico ha colaborado Itziar Fernández Martínez. 


\section{Dedicatoria:}

\section{A mi esposa Virginia,}

alma y motor de mi vida, por su complicidad y su apoyo diario, y por todo el tiempo que este trabajo le ha robado.

\section{A mi hijo Luís,}

por ser, junto con mi mujer, lo mejor de mi vida.

\section{A mis padres Luís y Catalina,}

por el esfuerzo y sacrificio en trasmitirme la educación y los valores importantes de este mundo, por su gran ejemplo, y por todo el amor que de ellos he recibido.

\section{A mis hermanos Catalina, Carmen, y Miguel,}

por su cariño y amistad, deseándoles los mayores éxitos familiares y profesionales. 


\section{Agradecimientos:}

Al Dr. Juan Jesús Cruz Hernández, director de este trabajo, por su permanente ayuda, por su empeño en crear esa gran escuela de profesionales en la que he tenido la dicha de formarme, por su estímulo y comprensión hacia mi persona, por todas sus enseñanzas recibidas y por trasmitirme con su ejemplo diario durante mis años de residente algo mucho más importante que la oncología: el trato personal y humano con el paciente. Siempre estaré en deuda.

Al Dr. Rogelio González Sarmiento, director de este trabajo, por su total disponibilidad, amabilidad y exquisito trato, por todas sus enseñanzas, por todo el tiempo dedicado a esta tesis, y por contagiarme la pasión por este tan ingrato trabajo que es la investigación.

Al Servicio de Oncología Médica del Hospital Clínico de Salamanca, a todas y cada una de las personas que lo conforman, y en especial al Dr. Germán Martín por su perseverancia en enseñarme día a día los conocimientos de esta apasionante especialidad, por sus ánimos y apoyo en los malos momentos, que ciertamente los hubo. Gracias de todo corazón.

Al Centro de Investigación del Cáncer, a todo el personal del laboratorio $14 \mathrm{y}$, en especial, a Eva María Sánchez, por toda la atención y ayuda que me han prestado, y a Sandra Perdomo, por su desinteresada ayuda y las horas dedicadas a enseñarme a trabajar en el laboratorio. 
A todo el personal de enfermería del Hospital Clínico de Salamanca, en especial a las plantas de Oncología, Cirugía Torácica, y Medicina Interna, por su ayuda en la extracción de muestras.

A todos los pacientes que han participado en este estudio y que tan amablemente me han permitido un "pinchazo" extra de los múltiples que han sufrido, pues sin ellos hubiera sido imposible realizar este trabajo.

A mi intimo amigo y compañero de fatigas, Pablo, por todos esos buenos momentos disfrutados juntos desde nuestra infancia hasta la licenciatura en Medicina y después, y por su siempre fiel e incondicional apoyo. A mis buenos amigos Juan, Toño, $\boldsymbol{y}$ Víctor, por la gran amistad que nos une y sus buenos consejos.

A Eduardo Pascua, por su apreciadísima ayuda en los momentos finales de este trabajo.

A mi amigo y profesor, José Ramón Ayllón, por su empeño en enseñarnos una educación en valores, tan olvidada en estos momentos, y que tanto me ha ayudado y guiado en esta vida para la toma de grandes y pequeñas decisiones. 
1. Cáncer de Pulmón. Aspectos Clínicos.

1.1. Concepto. Histogénesis. 2

1.1.1. Carcinoma no microcítico de pulmón 3

1.1.1.1. Carcinoma Epidermoide 3

1.1.1.2. Adenocarcinoma 4

1.1.1.3. Carcinoma de Células Grandes $\quad 4$

1.1.2 Carcinoma microcítico de pulmón 5

1.2. Epidemiología 5

1.2.1 Incidencia y mortalidad 5

1.2.2 Distribución 9

1.2.2.1 Por sexo 9

1.2.2.2 Por edad 9

$\begin{array}{lll}\text { 1.2.2.3 Por raza } & 9\end{array}$

$\begin{array}{lll}1.3 & \text { Factores de Riesgo } & 10\end{array}$

$\begin{array}{lll}\text { 1.3.1 Antecedentes Familiares } & 10\end{array}$

1.3.2. Antecedentes Personales 10

1.3.3. Dieta 10

1.3.4. Lugar de Residencia 11

1.3.5. Factores ocupacionales 11

1.3.6 Hábitos tóxicos: Tabaco 12

1.3.6.1. Epidemiología 12

1.3.6.2. Efectos del tabaco sobre la salud 16

$\begin{array}{ll}\text { 1.3.6.3. Relación tabaco y cáncer } & 17\end{array}$ 
1.3.6.4. Relación tabaco y cáncer de pulmón 18

1.3.6.5. Patología relacionada con el tabaquismo pasivo 20

1.4. Manifestaciones clínicas 21

1.4.1. Manifestaciones debidas al tumor 21

1.4.2. Manifestaciones debidas a la extensión locorregional 22

1.4.3. Manifestaciones de la enfermedad a distancia 22

1.4.4. Síndromes paraneoplásicos 23

$\begin{array}{lll}\text { 1.5. } & \text { Estadificación y Diagnóstico } 23\end{array}$

1.6. Factores pronósticos 28

1.6.1. Cáncer de pulmón no microcítico 28

1.6.1.1. Estadios precoces (Estadio I, II y III resecable) 28

1.6.1.2. Estadios avanzados (Estadio III no resecable y estadio IV) 28

1.6.2. Cáncer de pulmón microcítico 28

1.7. Tratamiento 29

1.7.1. Cáncer de pulmón no microcítico 29

1.7.1.1. Cirugía 29

1.7.1.2. Radioterapia 29

1.7.1.3. Quimioterapia 30

1.7.2. Cáncer de pulmón microcítico 31

1.7.2.1 Enfermedad limitada 31

1.7.2.2 Enfermedad diseminada 32

2. Biología molecular y genética del cáncer: Aspectos generales 33

3. Biología molecular y genética del cáncer de pulmón 37

3.1. Protooncogenes en Cáncer de Pulmón 37

3.1.1. Genes de la familia de los receptores del factor de crecimiento 37

3.1.2. Genes de la familia RAS 38 
3.2. Genes supresores en cáncer de pulmón: El gen TP53

3.3. Mutaciones en el gen TP53

3.4. Genes reparadores del DNA

4. Polimorfismos del DNA

4.1. Significado biológico

4.2. Polimorfismos del gen TP53

4.2.1. Relación del polimorfismo en el codon 72 de p53

con el cáncer de pulmón

4.2.3. Relación del polimorfismo en el intrón 3 de p53

con el cáncer de pulmón

4.3. Polimorfismos en los genes reparadores de tumores

XRCC1 y ERCC1 y relación con el cáncer de pulmón

Capítulo 2.- HIPÓTESIS Y OBJETIVOS

1. Objetivo principal

2. Objetivos secundarios

Capítulo 3.- MATERIAL Y MÉTODOS

1. Controles

2. Pacientes

3. Extracción y purificación del DNA 
3.1. Sangre periférica 71

3.2. Aislamiento del DNA de alto peso molecular 72

$\begin{array}{lll}\text { 4. } & \text { Estudio del codon } 72 \text { del gen p53 }\end{array}$

5. Estudio del polimorfismo del intron 3 del gen p53, arg194trp del gen xrcc1, y a19886g(thr75) del gen ercc1 75

$\begin{array}{lll}\text { 6. } & \text { Metodología } & 78\end{array}$

$\begin{array}{ll}\text { 7. Estudio de asociación genética } & 80\end{array}$

$\begin{array}{lr}\text { 7.1. Equilibrio de Hardy Weinberg } & 80\end{array}$

7.2. Tests de Asociación Genética 81

7.3. Test de Asociación: Múltiples SNP 83

$\begin{array}{lll}\text { 7.4. } & \text { Regresión Logística } & 84\end{array}$

8. Análisis estadístico de los resultados 86

Capítulo 4.- RESULTADOS 87

1. ANALISIS DE LAS VARIABLES NO GENETICAS 88

1.1. GRUPO DE PACIENTES CON CANCER DE PULMON 88

$\begin{array}{lll}\text { I. Sexo } & 88\end{array}$

$\begin{array}{ll}\text { II. } & \text { Edad en el diagnóstico }\end{array}$

$\begin{array}{lll}\text { III. } & \text { Tipo de profesión (riesgo, no riesgo) }\end{array}$

IV. Antecedentes de EPOC $\quad 91$

V. Antecedentes familiares oncológicos 92

VI. Número de años fumando $\quad 92$ 
1.2. GRUPO DE PACIENTES SIN CÁNCER DE PULMÓN 95

1.2.1. CONTROLES DE 65 AÑOS O MÁS 95

$\begin{array}{lll}\text { I. Edad } & 95\end{array}$

II Lugar de residencia $\quad 96$

III Tipo de profesión $\quad 96$

$\begin{array}{lll}\text { IV } & \text { Antecedentes de EPOC }\end{array}$

$\begin{array}{lll}\mathrm{V} & \text { Antecedentes familiares oncológicos } & 97\end{array}$

$\begin{array}{lll}\text { VI Número de años fumando } & 98\end{array}$

1.2.2. CONTROLES DE MENOS DE 65 AÑOS 99

I. Sexo 99

$\begin{array}{lll}\text { II. Edad } & 100\end{array}$

1.2.3. DIFERENCIAS ENTRE LAS DOS MUESTRAS CONTROL 101

1.2.4. DIFERENCIAS ENTRE CASOS Y CONTROLES 101

$\begin{array}{lll}\text { I. Sexo } & 101\end{array}$

II. Número de paquetes al día $\quad 101$

$\begin{array}{ll}\text { III. Número de años fumando } & 102\end{array}$

INFLUENCIA DE LOS FACTORES DE RIESGO

EN EL DESARROLLO DEL CÁNCER DE PULMÓN 103

$\begin{array}{ll}\text { 1.3.1. MODELO GENERAL } & 103\end{array}$

1.3.2. MODELO PARA MENORES DE 65 AÑOS 106

1.3.3 MODELO PARA 65 AÑOS O MÁS 110

2. ANALISIS DE LAS VARIABLES GENETICAS 115

2.1. ANÁLISIS PRELIMINAR:

EQUILIBRIO DE HARDY WEINBERG 115 
2.1.1. CONTROLES CON 65 AÑOS O MÁS 115

2.1.2. CONTROLES CON MENOS DE 65 AÑOS 117

2.1.3. TODOS LOS CONTROLES 118

$\begin{array}{lll}\text { 2.1.4. CASOS } & 119\end{array}$

$\begin{array}{llr}\text { 2.2. TESTS DE ASOCIACIÓN } & 121\end{array}$

2.2.1. CONTROLES CON 65 AÑOS O MÁS 122

$\begin{array}{lll}\text { I. } & 122\end{array}$

$\begin{array}{lll}\text { II. } & \mathrm{XRCC} 1 & 124\end{array}$

$\begin{array}{ll}\text { III. P53 Exón } 4 & 125\end{array}$

$\begin{array}{ll}\text { IV. P53 intron } 3 & 127\end{array}$

2.2.2. CONTROLES CON MENOS DE 65 AÑOS 129

$\begin{array}{ll}\text { I. } & 53 \text { Exón } 4 \\ & 130\end{array}$

$\begin{array}{ll}\text { II. P53 intron } 3 & 130\end{array}$

2.2.3. CONTROLES TOTALES 133

$\begin{array}{lll}\text { I. P53 } & 133\end{array}$

$\begin{array}{lll}\text { II. } & \text { P53 intron } 3\end{array}$

2.3. REGRESIÓN LOGÍSTICA 138

2.3.1. CONTROLES CON 65 AÑOS O MÁS 138

$\begin{array}{lll}\text { I. } & \text { ERCC1 } 138\end{array}$

$\begin{array}{lll}\text { II. } & \text { XRCC1 } 139\end{array}$

$\begin{array}{ll}\text { III. P53 codon } 72 & 140\end{array}$

$\begin{array}{lll}\text { IV. } & \text { P53 intron } 3 & 141\end{array}$

2.3.2. CONTROLES CON MENOS DE 65 AÑOS 142

I. $\quad$ P53 codon $72 \quad 142$

$\begin{array}{lll}\text { II. } & \text { P53 intron } 3\end{array}$

2.3.3. CONTROLES TOTALES 145 
$\begin{array}{lll}\text { I. } & \text { P53 }\end{array}$

II. P53 intron $3 \quad 146$

$2.4 \quad$ TEST DE ASOCIACIÓN: MÚLTIPLES SNP 147

2.4.1. SÓLO VARIABLES GENÉTICAS 147

2.4.1.1. CONTROLES CON 65 AÑOS o MÁS 147

2.4.1.2 CONTROLES MENORES DE 65 AÑOS 150

2.4.1.3 CONTROLES TOTALES 152

2.4.2 INCLUYENDO VARIABLES NO GENÉTICAS 154

2.4.2.1. RELACIÓN ENTRE LAS VARIABLES NO GENÉTICAS CON LOS SNP 154

$\begin{array}{ll}\text { I. } & 154\end{array}$

II. XRCC1 155

$\begin{array}{lll}\text { III. } & \text { P53 codon } 72 & 157\end{array}$

IV. P53 Intron $3 \quad 163$

2.4.2.2. RIESGO DE PADECER CANCER CONSIDERANDO ESTAS VARIABLES 169

$\begin{array}{ll}\text { I. } & 170\end{array}$

$\begin{array}{lll}\text { II. } & \text { XRCC1 } & 174\end{array}$

$\begin{array}{lll}\text { III. } & \text { P53 codon } 72 & 177\end{array}$

IV. $\quad$ P53 Intron $3 \quad 181$

Capítulo 5.- DISCUSIÓN 184

1. Estudio de las variables no genéticas. Influencia de los factores de riesgo en el desarrollo de cáncer de pulmón 185

2. $\quad$ Estudio del Polimorfismo en el codon 72 del Exón 4 de p53 187

3. Estudio del Polimorfismo en el intrón 3 de p53 193 
4. Estudio del Polimorfismo en el Gen XRCC1

5. Estudio del Polimorfismo en el Gen ERCC1

Capítulo 6.- CONCLUSIONES

Capítulo 7.- BIBLIOGRAFÍA

208 


\section{1.- INTRODUCCIÓN}




\section{1.- Cáncer de pulmón. Aspectos clínicos.}

\section{1.- Concepto. Histogénesis.}

El cáncer de pulmón es una neoplasia que, como en el resto de tumores, deriva de una célula madre pluripotencial capaz de expresar una variedad de fenotipos distintos. La célula madre epitelial se diferencia a células del árbol traqueobronquial incluyendo células pseudoestratificadas de reserva, células columnares ciliadas, células neuroendocrinas y neumocitos alveolares tipo I y II. Todas las células capaces de dividirse pueden sufrir cambios como hiperplasia, metaplasia y neoplasia ${ }^{1}$.

De acuerdo con la clasificación histológica del cáncer de pulmón, distinguimos los siguientes tipos histológicos (Tabla 1)

Tabla 1. Clasificación histológica del cáncer de pulmón.

\begin{tabular}{|c|}
\hline CARCINOMA NO MICROCÍTICO DE PULMÓN \\
\hline - Carcinoma de células escamosas (Epidermoide) \\
\hline - Variedad de células fusiformes \\
\hline - Adenocarcinoma \\
\hline - Acinar \\
\hline - Broncoalveolar \\
\hline - Tumor sólido con mucina \\
\hline - Carcinoma de células grandes \\
\hline - Células gigantes \\
\hline - Células claras \\
\hline - Carcinoma adenoescamoso \\
\hline - Carcinoma indiferenciado \\
\hline
\end{tabular}




\begin{tabular}{|l||}
\hline CARCINOMA MICROCÍTICO DE PULMÓN. \\
\hline - Variedad carcinoma de células pequeñas \\
\hline - Variedad carcinoma mixto de células pequeñas y grandes. \\
\hline de células pequeñas combinado con componentes neoplásicos \\
escamosos y/o glandulares). \\
\hline
\end{tabular}

En el cáncer de pulmón se observan con frecuencia dos ó más patrones histológicos; de hecho, en un 10\% de las muestras histológicas se observan elementos de carcinoma epidermoide y adenocarcinoma ${ }^{2}$. El 95\% de las neoplasias malignas de pulmón se engloban en uno de los siguientes tipos anatomopatológicos ${ }^{3}$.

- Carcinoma epidermoide o de células escamosas

- Carcinoma microcítico

- Adenocarcinoma.

- Carcinoma indiferenciado de células grandes pulmonar o de células gigantes o anaplásico de células grandes

\subsection{1.- Carcinoma no microcítico de pulmón}

\subsubsection{1.- Carcinoma Epidermoide}

Representa el $30 \%$ de todos los tumores malignos de pulmón y es el más común en el varón. En nuestro medio es el tipo más habitual y el más relacionado con el tabaco. Deriva del epitelio de revestimiento bronquial y su crecimiento es lento. Con un tiempo de duplicación de 90 días, se estima que tardan tres ó cuatro años desde el desarrollo de un carcinoma "in situ" a un tumor plenamente establecido. Tienden a ser centrales y a acompañarse de neumonitis obstructiva y adenopatías hiliares. Aparece frecuentemente en el segmento proximal del bronquio y se asocia con metaplasia escamosa. Histológicamente, la característica microscópica más destacada es la 
presencia de células epiteliales en forma de hoja que pueden estar bien o mal diferenciadas. Las mejor diferenciadas muestran perlas de queratina. Es habitual la aparición de una marcada respuesta en el tejido pulmonar, con infiltrados linfoplasmocitarios y células histiocitarias gigantes.

\subsubsection{2.- Adenocarcinoma}

$\mathrm{Su}$ incidencia ha aumentado de forma importante y actualmente supone el 35-40\% de todos los casos de cáncer de pulmón, siendo el tumor más frecuente en USA. La mayoría son periféricos y se originan del epitelio alveolar o de las glándulas mucosas bronquiales. Histológicamente se caracteriza por la formación de estructuras glandulares atípicas con formación de moco.

El carcinoma bronquioloalveolar se considera una entidad clinicopatológica distinta dentro de los diversos tipos de adenocarcinoma ${ }^{4}$, representando el 5\% de todos los casos de cáncer de pulmón. Puede originarse a partir de los neumocitos tipo II, células mucosecretoras ó células de la clara. Clínicamente puede presentarse de tres formas: como nódulo solitario periférico, como enfermedad multifocal o en la forma neumónica rápidamente progresiva. Tiene una diseminación ganglionar temprana, metastatizando por vía hemática más precozmente que los otros. Es el tumor menos asociado con el tabaco y el más frecuente en las mujeres no fumadoras, relacionándose con la existencia de cicatrices y enfermedades pulmonares previas como la esclerodermia o la fibrosis pulmonar.

\subsubsection{3.- Carcinoma de Células Grandes}

$\mathrm{Su}$ incidencia ha disminuido al $10-15 \%$ de todos los cánceres de pulmón al mejorar los métodos diagnósticos con la introducción de la inmunohistoquímica y la microscopía electrónica ${ }^{5}$. No obstante, aunque está reconocido como un tipo histológico concreto, es muy posible que se trate de un grupo heterogéneo que engloba variantes poco diferenciadas de adenocarcinoma y carcinoma epidermoide. Al 
microscopio se caracteriza por presentar células grandes con abundante citoplasma y sin diferenciación escamosa ó glandular ni evidencia de secreción de moco. Existe un subtipo con diferenciación neuroendocrina en el que se ha postulado que, al igual que el carcinoma de células pequeñas, podría tener una buena respuesta al tratamiento quimioterápico. Clínicamente aparece como una gran masa periférica, con afectación hiliar y áreas de neumonitis.

\subsection{2.- Carcinoma microcítico de pulmón}

Aparece en un 10-20\% de los casos de cáncer de pulmón en varones y 10-30\% en mujeres ${ }^{6}$, siendo el tabaco el responsable del $90 \%$ de los casos ${ }^{7}$. Es un tumor que deriva de células neuroendocrinas del epitelio bronquial, las células de Kulchitsky. Estas células presentan gránulos que secretan hormonas peptídicas como la enolasa neuroespecífica, la L-dopa decarboxilasa o el GRP. La aparición de estos marcadores de diferenciación neuroendocrina es característica pero no patognomónica, pudiendo estar presente hasta en un $75 \%$ de carcinomas no microcíticos ${ }^{8}, 9$. Al microscopio se observan células de pequeño tamaño, núcleo hipercromático y escaso citoplasma, asemejándose a linfocitos, con gran cantidad de mitosis y elevada presencia de necrosis. Suele tener una localización central y presentar adenopatías mediastínicas, siendo una de las principales causas de SVCS (síndrome de vena cava superior). Clínicamente es un tumor muy agresivo con un tiempo de duplicación muy corto (30 días) y con una gran capacidad para metastatizar por vía hemática y linfática. Está muy relacionado con síndromes paraneoplásicos como el de Eaton-Lambert, el de secreción inadecuada de ADH (SIADH) o el de Cushing. La variedad de carcinoma de células pequeñas combinado suele ser más localizado y tener mejor pronóstico, representando el $20 \%$ de todos los carcinomas de células pequeñas.

\section{2.- Epidemiología.}

\subsection{1.- Incidencia y mortalidad.}


El cáncer de pulmón es una de las neoplasias malignas más frecuentes y una de las pocas cuya incidencia global aumenta a un ritmo de un $0^{\prime} 5 \% \mathrm{y}$, en la actualidad, supera al cáncer de mama, próstata y colon combinados ${ }^{10}$. El número de casos ha ido en ascenso desde principios del siglo pasado, cuando se consideraba que la mayor parte de los tumores pulmonares eran metastásicos y que el cáncer primitivo era raro, incrementando su incidencia en varones de forma exponencial hasta la década de los ochenta, y en mujeres a partir de los años 60.

Con el objetivo de conocer y comparar los datos de diferentes países a nivel mundial, en 1989 nace el proyecto GLOBOCAN, que recoge datos de incidencia y mortalidad de diferentes registros de cáncer, utilizando la misma metodología. En el año 1999 se publicaron los datos de dicho proyecto, según el cual el cáncer de pulmón fue el tumor más frecuente en 1990, tanto en incidencia (1.04 millones de casos nuevos; $12.8 \%$ del total mundial) como en mortalidad (921.000 muertes; $17.8 \%$ del total mundial); el 58\% de los casos nuevos ocurrieron en países desarrollados ${ }^{11}$ (Tabla 2). En Estados Unidos, el cáncer de pulmón encabeza la causa de muerte por cáncer en los varones $\mathrm{y}$, desde finales de la década de los ochenta, ha superado al cáncer de mama como principal causa de muerte por cáncer ${ }^{12}$. Al igual que el proyecto GLOBOCAN, en Europa se desarrolla el proyecto EUROCARE, que recoge datos de supervivencia de diferentes registros de cáncer, utilizando la misma metodología con el objetivo de conocer y comparar los datos de diferentes países europeos. En el año 2003 se publicaron los datos del proyecto EUROCARE III, en el que se analizan las historias de más de un millón ochocientos mil adultos y 24.000 niños, que incluyen 44 tipos de tumores diagnosticados entre 1990 y 1994 y que han sido seguidos hasta 1999. Los datos han sido proporcionados por diferentes registros poblacionales de cáncer de 22 países europeos. Según este estudio, el cáncer de pulmón se encuentra dentro de los más letales con la tasa de supervivencia a los 5 años durante el periodo 1990-1994 de un 9,7 $\%$ y un 9,6 \% en los hombres y mujeres europeas, y de un $12,4 \%$ y un $12,8 \%$ en los hombres y mujeres españoles ${ }^{13}$. Comparativamente con los resultados del quinquenio anterior, recogidos en el proyecto EUROCARE II se observó una mejora global de la supervivencia en los pacientes españoles de un $9 \%{ }^{14}$.

Estudio de los polimorfismos de genes reparadores en población fumadora con y sin cáncer de pulmón 
Tabla 2. Número de casos nuevos y mortalidad mundial por tipo de cáncer. Fuente: Globocán.

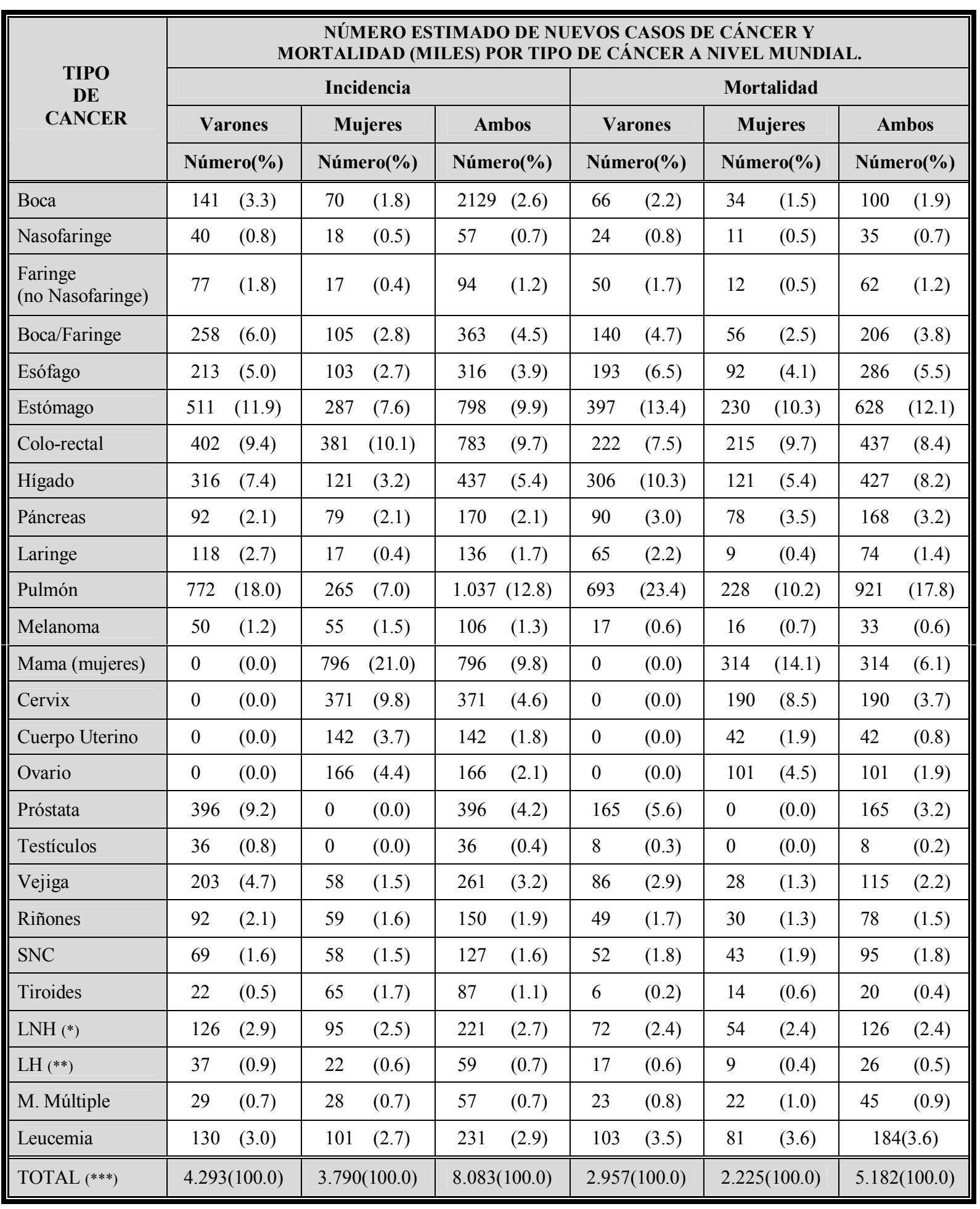

(*) Linfoma no Hodgking $\quad\left(^{* *}\right)$ Linfoma de Hodgking

${ }_{(* * *) \quad S e}$ excluye tumores de piel no melanomas 
En España, el cáncer de pulmón es el tumor más frecuente en los varones (figura 1). Se han contabilizado 17.000 nuevos casos en hombres y 1.500 nuevos casos en mujeres, siendo responsable de 16.000 muertes en hombres y 1.350 en mujeres en el año $2000{ }^{15}$. En el año 2003 se diagnosticaron 18.800 nuevos casos, siendo el segundo tumor en ambos sexos en términos absolutos tras el carcinoma colorrectal ${ }^{16}$. La escasa diferencia entre el número de casos prevalentes e incidentes refleja la alta letalidad de este tumor. Dentro de nuestro país, las tasas mas altas de mortalidad se localizan en el suroeste (Cádiz y Sevilla) y en parte de las provincias del norte (Asturias y Vizcaya), llamando la atención la alta mortalidad en las mujeres de Las Palmas ${ }^{17}$.

Comparación de las tasas de mortalidad por los principales cánceres en España. 1984-1994-2004. Sexo masculino. (tasas ajustadas a la población europea: muertes/100.000 h/año).

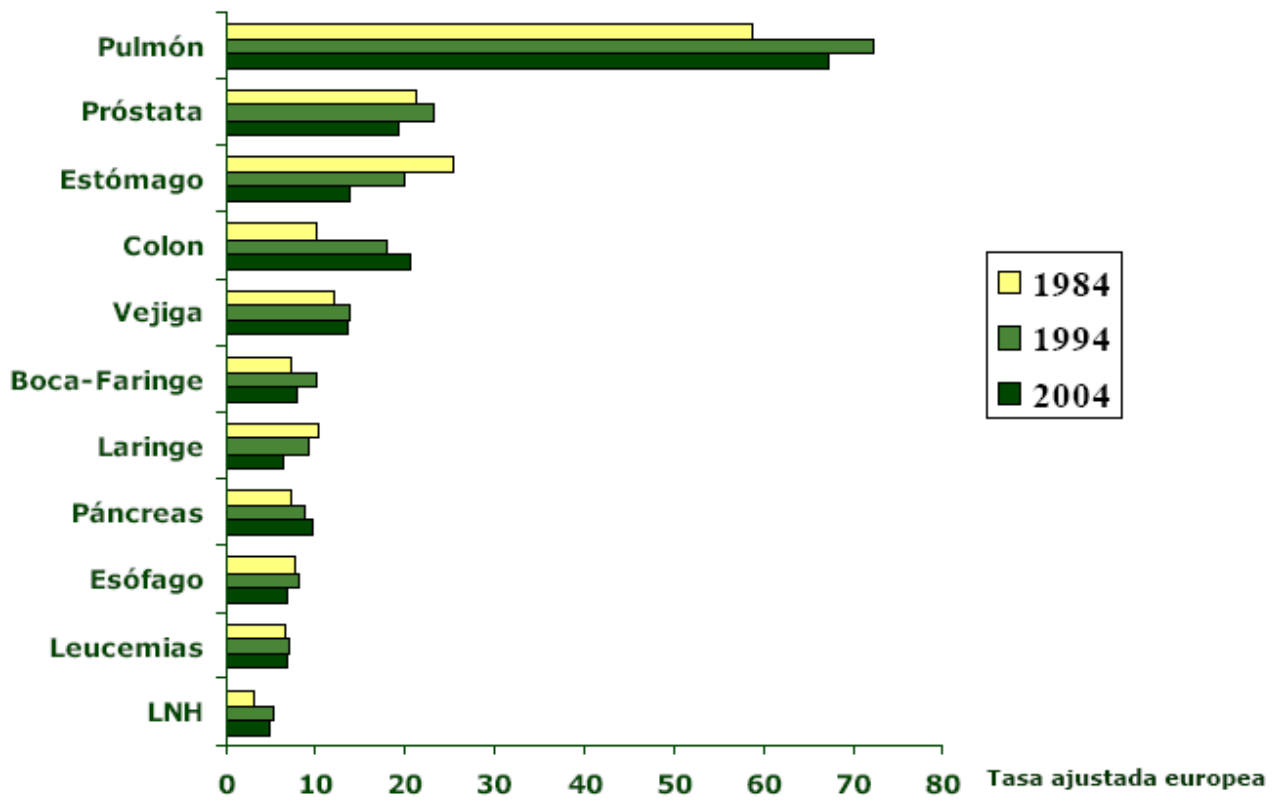

Figura 1. Mortalidad por Cáncer y otras causas en España. Años 1984, 1994 y 2004.

Fuente: Centro Nacional de Epidemiología. Elaboración FCAECC 


\subsection{2.- Distribución.}

\subsubsection{1.- Sexo.}

A nivel mundial, el cáncer de pulmón es la neoplasia más frecuente en el varón, con las tasas observadas más altas en América del Norte y Europa, especialmente Europa del Este. En 1990 las tasas de incidencia en mujeres eran bajas, con una tasa global de 10.8 por 100.000 mujeres frente a 37.5 por 100.000 hombres ${ }^{11}$.

En Estados Unidos la tasa de incidencia de cáncer de pulmón en varones alcanzó su pico en 1984 (86.5 por 100.000 hab.) y de forma paralela la tasa de mortalidades en 1990 (75.2 por 100.000 hab.); ambas han ido descendiendo desde entonces, mientras que la tasa de incidencia y mortalidad en las mujeres ha ido en aumento. La proporción entre sexos ha pasado de ser siete veces mayor en los hombres hace unos años a una relación 2:1 en la actualidad y desde finales de los años 80 constituye la causa más frecuente de muerte por cáncer en la mujer, por delante del cáncer de mama. ${ }^{10,18}$.

En Europa, la relación varón: mujer es de 5:1 y en España es de 11:1, reflejando el retraso en el hábito tabáquico y el menor riesgo laboral en las mujeres españolas ${ }^{17}$. Se ha sugerido que para un mismo nivel de exposición al tabaco, las mujeres tienen un riesgo mayor que los varones ${ }^{19,20}$.

\subsubsection{2.- Edad.}

El cáncer de pulmón afecta sobre todo a personas mayores de 50 años, siendo el promedio de edad al diagnóstico de 60 años, si bien cada vez se diagnostican más casos en sujetos jóvenes ${ }^{19,20}$.

\subsubsection{3.- Raza.}

Las tasas de incidencia de cáncer de pulmón varían ampliamente según la raza y la etnia. Así en USA, existe una gran diferencia entre las elevadas tasas que presentan los 
afroamericanos, con 73.9 casos por 100.000 hab., frente a los 27.6 casos por 100.000 hab. que presenta la población hispana ${ }^{18}$. Igualmente, los varones de raza negra parecen tener un riesgo más elevado que los varones caucásicos para desarrollar un cáncer de pulmón con un mismo nivel de consumo de tabaco ${ }^{10,20}$.

\section{3.- Factores de Riesgo.}

La etiología del cáncer de pulmón es desconocida, pero existen determinados factores de riesgo que están muy relacionados con el cáncer de pulmón.

\subsection{1.- Antecedentes familiares.}

El riesgo a desarrollar cáncer de pulmón tras exposición a una sustancia carcinogénica está influenciado por la susceptibilidad genética de las personas, de forma que los individuos no fumadores con familiares con cáncer de pulmón tienen un riesgo dos o tres veces mayor de desarrollar cáncer de pulmón que aquellos sin historia familiar $^{21-24}$.

\subsection{2.- Antecedentes personales.}

La existencia de enfermedades pulmonares subyacentes se ha asociado con un mayor riesgo de desarrollar cáncer de pulmón, siendo la fibrosis pulmonar idiopática y la enfermedad obstructiva crónica las dos entidades que se asocian con un mayor riesgo 25-29. En el caso de la enfermedad obstructiva crónica, el tabaco se ha demostrado como el principal factor de riesgo para desarrollarla ${ }^{30,31}$.

\subsection{3.- Dieta.}

La ingesta de alimentos ricos en beta-carotenos, como las frutas y vegetales, parecen tener un efecto protector sobre el cáncer de pulmón debido a su efecto antioxidante ${ }^{32-36}$, si bien estudios más recientes han demostrado un efecto deletéreo con la suplementación de la dieta con beta-carotenos ${ }^{37-47}$. Se ha señalado un efecto protector 
del consumo de otros nutrientes, como el acido fólico, el selenio y las vitaminas A y $\mathrm{E}^{35}$.

\subsection{4.- Lugar de residencia.}

Se ha sugerido que la polución atmosférica podría suponer un riesgo en zonas urbanas con gran densidad de población debido a la mayor incidencia de cáncer de pulmón en personas fumadoras residentes en áreas urbanas con respecto a las rurales ${ }^{10}$.

\subsection{5.- Factores Ocupacionales.}

La exposición al Asbesto representa el factor de riesgo laboral más fuertemente asociado al desarrollo de cáncer de pulmón, siendo el responsable del 3-4\% de los casos diagnosticados a nivel mundial. El periodo de latencia entre la primera exposición al asbesto y la aparición del carcinoma suele ser de 20 años, existiendo una gran relación entre la intensidad de la exposición y el riesgo de desarrollar cáncer de pulmón, de forma que una exposición corta puede causar cáncer de pulmón si ha sido suficientemente intensa ${ }^{48-50}$. En los trabajadores en contacto con asbesto, así como con otros carcinógenos ambientales, el tabaco ejerce un efecto multiplicativo del riesgo, y se cree que el asbesto actuaría de cocarcinógeno del tabaco ${ }^{51-53}$.

El riesgo asociado a la exposición del gas radón a través de los cimientos de los

edificios es controvertido ${ }^{49}$. Otros factores ocupacionales que aumentan el riesgo de desarrollar cáncer de pulmón son los compuestos de arsénico (mineros, fundidores, agricultores que utilizan pesticidas), níquel, berilio, cadmio e hidrocarburos policíclicos aromáticos. 


\subsection{6.- Hábitos tóxicos: tabaco.}

\subsubsection{1.- Epidemiología.}

El tabaquismo representa un importante y costoso problema de salud pública, siendo considerado por la Organización Mundial de la Salud (OMS) como una de las amenazas más graves para la salud mundial, representando la principal causa de enfermedad y muerte prematura en los países occidentales.

En 1993 Peto et al. publicaron un informe sobre la mortalidad en los países desarrollados durante los años 1950-2000 en el que se estimaba que, al menos, 50 millones de muertes en hombres y 10 millones en mujeres podrían ser atribuidas al consumo de tabaco en mayores de 35 años ${ }^{54}$.

El tabaco provoca 4 millones de muertes al año a nivel mundial, y 1,2 millones en la Unión Europea, estimándose que esta cifra aumente a 10 millones en el mundo y 2 millones en Europa en el año 2020, año en el una de cada seis muertes estará relacionada con el consumo de tabaco ${ }^{55,56}$. Uno de cada dos fumadores morirán prematuramente como consecuencia de enfermedades atribuibles al consumo de tabaco, con una estimación de unos 10 años de media de vida perdida por dicha causa ${ }^{57,58}$.

En España, aproximadamente el 36\% de la población mayor de 16 años consume tabaco de forma regular y en el 90\% de casos el inicio comienza antes de los 20 años, siendo el tabaquismo la primera causa evitable de muerte en nuestro país (56.000 personas al año). Por autonomías, la prevalencia más baja se sitúa en Castilla-La Mancha, Baleares y Aragón ( 32 y 34\% respectivamente ), y la más alta en Cantabria y Murcia (42 y 40\% respectivamente), situándose Castilla y León, con una prevalencia del $35 \%$, dentro de las comunidades con una menor incidencia (Figura $2{ }^{59}$. 
Según los datos de la Encuesta Nacional de Salud de 1997, en España el 45\% de los varones y el $27 \%$ de las mujeres mayores de 15 años son fumadores, lo cual representa al 36\% de la población general. El grupo de 25 a 44 años representa el intervalo con población fumadora más alto (52\%), seguido por el grupo de 16 a 24 años (40\%). Comparando estos datos con la encuesta del año 1987 se aprecia una reducción del consumo en los hombres (del 55 al 45\%) respecto al incremento en las mujeres (del 23 al 27\%) (Tabla 3$)^{59}$.

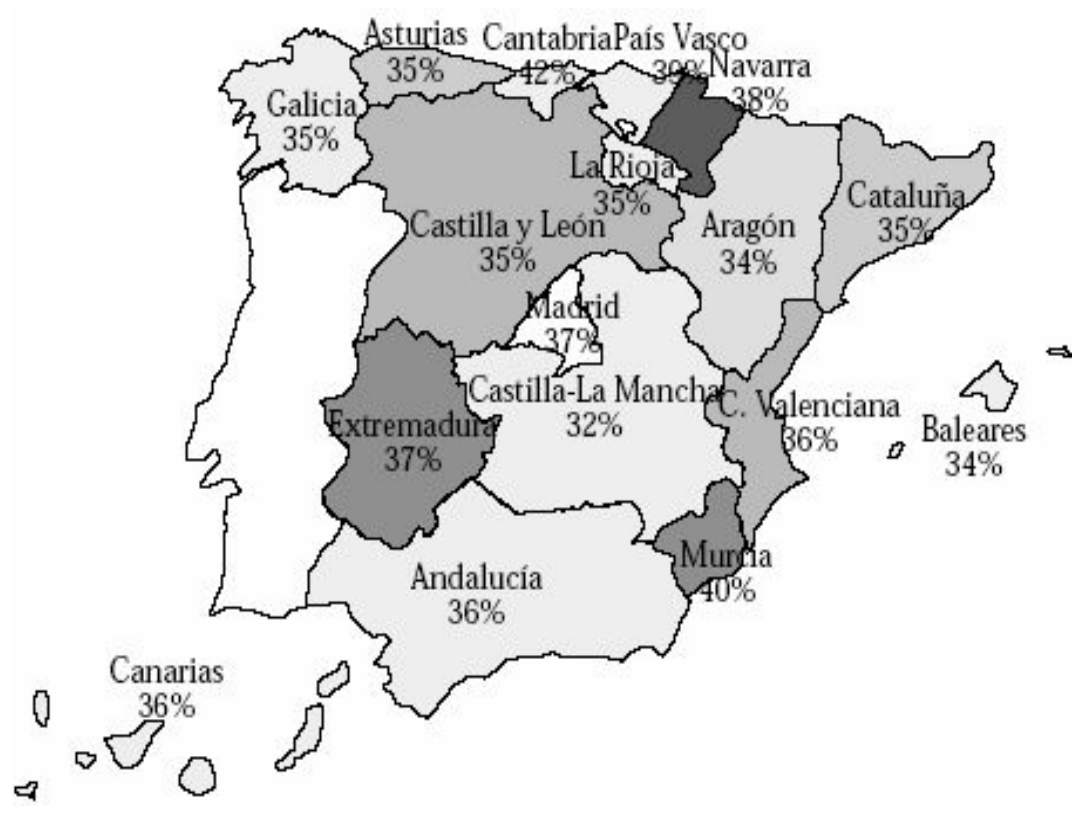

Figura 2. Porcentaje de fumadores mayores de 15 años en las diferentes comunidades autónomas (Encuesta Nacional de Salud de 1993). Tomado de Manual de Prevención y Tratamiento del Tabaquismo; 2001.

Esta tendencia al alza en las mujeres, tanto en España como en Europa, es preocupante y muestra la necesidad de una estrategia eficaz en la lucha antitabáquica dirigida de forma específica a la población femenina ${ }^{60}$. 
Tabla 3. Porcentaje de fumadores por grupos de edad en España en 1997.

Tomado de Manual de Prevención y Tratamiento del Tabaquismo; 2001.

\begin{tabular}{lccc}
\hline Grupo de edad & Fumador & Exfumador & No fumador \\
\hline $16-24$ & 40 & 5 & 55 \\
$25-44$ & 52 & 14 & 33 \\
$45-64$ & 27 & 18 & 54 \\
$64-74$ & 12 & 21 & 67 \\
$\geq 74$ & 8 & 25 & 66 \\
\hline
\end{tabular}

Si comparamos estos datos con los de la última encuesta nacional de salud del año 2006, se aprecia una claro descenso del hábito tabáquico en todos los grupos de edad (tabla 4).

Tabla 4. Porcentaje de fumadores por grupos de edad en España en 2006.

Fuente: Ministerio de Sanidad y Consumo (INE). Encuesta Nacional de Salud de España. Avance de resultados junio 2006-enero 2007. Tablas estadísticas con datos provisionales a nivel nacional

\begin{tabular}{||c|c|c|c|c||}
\hline Grupo de edad & Fumador & Fumador ocasional & Exfumador & No fumador \\
\hline \hline $16-24$ & 27 & 3 & 21 & 49 \\
\hline $25-44$ & 28 & 5 & 7 & 60 \\
\hline $45-64$ & 27 & 3 & 27 & 43 \\
$>75$ & 7 & 0.5 & 27 & 65.5 \\
\hline
\end{tabular}

Se calcula que en el mundo existen aproximadamente un mil millones de fumadores. Dicho de otra manera, un tercio de la población mundial mayor de 15 años es fumadora ${ }^{61}$.

Estratificándolo por sexos, el intervalo de edad que engloba una mayor proporción de individuos fumadores tanto para varones como para mujeres es el comprendido entre los 30 y 49 años. Dentro de este intervalo de edad, un $47 \%$ de los varones y un $11 \%$ de las mujeres consumen 14 cigarrillos/día de media, representando al año un consumo de 
5.827 billones de cigarrillos. En sexo masculino, las mayores prevalencias mundiales se localizan en países como Vietnam, Corea y la República Dominicana (73, 68 y 66\%, respectivamente), a diferencia de el sexo femenino, en donde el continente europeo presenta las tasas más altas, en concreto Dinamarca y Noruega (37 y 36\% respectivamente). Las prevalencias más elevadas de consumo a nivel mundial se alcanzan en Asia y Europa Central, y las más bajas en el África Subsahariana. En número, la mayor parte de los fumadores se agrupan en China $(63 \%$ de varones fumadores y $4 \%$ de mujeres), India ( $40 \%$ de varones fumadores, $3 \%$ de mujeres) y la Federación Rusa (63\% de varones fumadores, 30\% de mujeres) debido a su elevado volumen de población ${ }^{62}$.

En Europa, en donde la mayor población de fumadores está situada en los países mediterráneos, se está produciendo una disminución paulatina del consumo, con una mayor prevalencia en los hombres excepto en Suecia, donde el consumo es un poco más elevado en las mujeres (Figura 3) ${ }^{59}$.

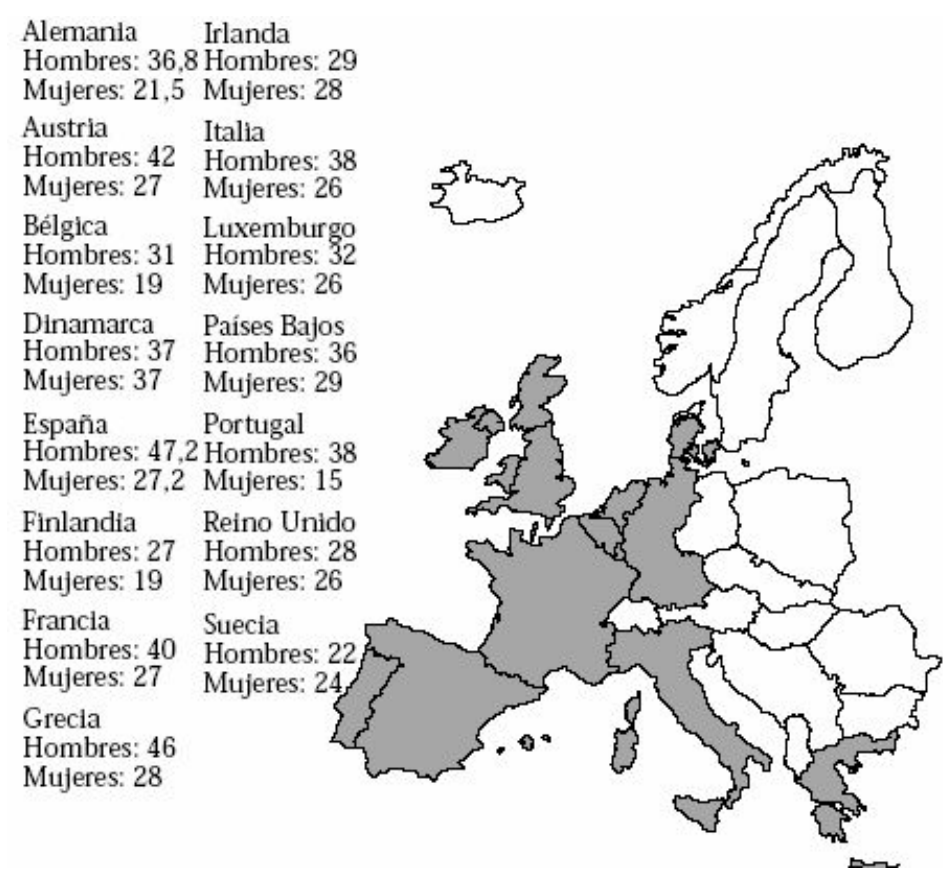

Figura 3. Porcentaje según el sexo de fumadores mayores de 15 años en los países de la UE. 1996. Tomado de Manual de Prevención y Tratamiento del Tabaquismo; 2003. 


\subsubsection{2.- Efectos del tabaco sobre la salud.}

El tabaquismo representa el principal problema de salud pública en los países desarrollados debido a las consecuencias sanitarias y a los importantes costes sociales y económicos que acarrea, siendo considerada una forma de drogodependencia. E1 consumo de tabaco se ha asociado a más de veinticinco enfermedades y es en la actualidad uno de los factores de riesgo más importantes para la salud de la población española, siendo el causante de más del $80 \%$ de los casos de enfermedad pulmonar obstructiva crónica (EPOC) y de aproximadamente el $20 \%$ de las muertes por enfermedades coronarias y accidentes cerebrovasculares y del $30 \%$ por cáncer ${ }^{63,64}$.

En 1998 se atribuyeron al tabaco 55.613 muertes en España, lo que supone el 16\% de los fallecimientos en personas de edad igual o superior a 35 años, sucediendo la mayoría de ellas en varones. Dos de cada tres fallecimientos se debieron a las enfermedades más prevalentes asociadas con el tabaco y anteriormente citadas: cáncer de pulmón (26,5\%), EPOC (20,9\%), cardiopatía isquémica (12,8\%) y enfermedad cerebrovascular $(9,2 \%)$, predominando los tumores malignos $(40,7 \%)$ en los hombres y las enfermedades cardiovasculares $(45,1 \%)$ en las mujeres. ${ }^{64}$.

En nuestro país, el cáncer de pulmón continua siendo la primera causa de muerte atribuible al tabaco en el sexo masculino, y en mujeres es, por detrás de la EPOC, la segunda causa de muerte atribuible habiendo superado a la enfermedad cerebrovascular 65. En 2005 se produjeron en España 16.647 defunciones por cáncer de pulmón en varones y 2.471 en mujeres, lo que representa el 26,6 y el $6,6 \%$ de la mortalidad por tumores, respectivamente ${ }^{66}$. Resumiendo las consecuencias del consumo de tabaco, podríamos decir que la mitad de los fumadores que se inician en el hábito tabáquico a edad temprana y lo mantienen de forma regular durante toda su vida, fallecerán a mediana edad por una enfermedad relacionada con el tabaco, perdiendo unos 20 años de esperanza de vida ${ }^{67,68}$. 


\subsubsection{3.- Relación tabaco y cáncer.}

En 1914 fue demostrado por primera vez la naturaleza carcinógena de diferentes hidrocarburos del humo de los cigarrillos ${ }^{69}$, si bien ya en el siglo XVIII John Hill sugirió la relación entre consumo de tabaco y cáncer ${ }^{70,71}$. En 1923 se postuló que el tabaco podría ser un factor etiológico principal del carcinoma broncopulmonar ${ }^{72}$. En 1928 Lombard y Doering publicaron un informe en donde se apreciaba una mayor tasa de fumadores entre los pacientes con cáncer que entre los controles ${ }^{73}$, y en 1941 Alton Ochsner reconoció la interrelación entre el tabaquismo y la incidencia aumentada de cáncer broncopulmonar ${ }^{74}$. Más tarde los trabajos epidemiológicos de Doll y Hill ${ }^{75}$, Wynder y Gram ${ }^{76}$, y Hammond y Horn ${ }^{77}$, permitieron concluir que el tabaco es la principal causa de cáncer de pulmón en los hombres, y fue relacionado como un factor causal del cáncer de laringe y cavidad oral ${ }^{78}$. Actualmente son más de 60.000 los estudios que relacionan el consumo de tabaco y el cáncer. Se calcula que el $75 \%$ de los cánceres humanos están relacionados con la exposición a carcinógenos químicos, sustancias que, actuando sobre una célula, producen alteraciones específicas cuyo resultado final es el desarrollo tumoral ${ }^{79}$.

Los carcinógenos se clasifican en directos, capaces por sí mismos de causar lesiones neoplásicas a las dosis apropiadas, e indirectos, que necesitan de una activación metabólica previa para actuar como verdaderos carcinógenos. Dentro de los carcinógenos indirectos se pueden distinguir los factores promotores, que son sustancias inactivas por sí pero que unidas a otras pueden ser activadoras del proceso; los factores iniciadores, que son aquellas sustancias capaces de originar alteraciones específicas; y los cocarcinógenos, sustancias que unidas a los iniciadores pueden desarrollar todo el proceso. Los factores iniciadores y promotores son responsables del 20-40\% de las muertes humanas por cáncer procedentes del tabaco ${ }^{80}$.

Al consumir un cigarrillo distinguimos dos tipos de corrientes de humo, una principal, que es inhalada por el fumador y que contiene un $25 \%$ del total, y una corriente lateral, con el 75\% restante, procedente de la combustión pasiva del tabaco 
que pasa al aire ambiente, encontrándose productos carcinógenos en ambas corrientes de humo. La fase de partícula de la corriente principal contiene los principales compuestos carcinógenos. Los compuestos nocivos que se encuentran en la corriente lateral son los responsables de la aparición de neoplasias en fumadores pasivos ${ }^{81}$.

Si bien el principal efecto carcinógeno del tabaco en el organismo ocurre sobre aquellos tejidos directamente expuestos al humo del cigarrillo, los carcinógenos presentes en el tabaco además de ser inhalados se disuelven en la saliva, pasando a la circulación sistémica y eliminándose por la orina.

De las más de 3500 sustancias químicas diferentes que se han descrito en el humo del tabaco ${ }^{82}$, más de 20 son potentes carcinógenos, como los hidrocarburos aromáticos policíclicos, nitrosaminas y aminas aromáticas, y otras como ciertos derivados del fenol son promotores de la carcinogénesis ${ }^{79}$. Algunas de estas sustancias actúan en varios escalones del proceso canceroso, produciendo alteraciones tanto de los oncogenes como de los genes supresores tumorales, y dentro de estos últimos es especialmente relevante las alteraciones en el gen TP53 ${ }^{83}$.

El tabaco se ha relacionado con el cáncer de pulmón, laringe, orofaringe, esófago, estómago, páncreas, hígado, colon-recto, riñón, vejiga, mama, aparato genital y órganos linfáticos ${ }^{84-86}$.

\subsubsection{4.- Relación tabaco y cáncer de pulmón.}

Numerosos estudios epidemiológicos han establecido la relación entre el consumo de tabaco y el cáncer de pulmón ${ }^{87,88}$. El tabaco es responsable directo de más del 90\% de los casos de cáncer de pulmón en los varones y del 55-80\% de los casos en las mujeres ${ }^{89}$, existiendo una clara relación dosis-respuesta entre el riesgo y el consumo diario de cigarrillos ${ }^{82}$, incrementando el riesgo en los cuatro tipos histológicos principales de cáncer de pulmón: de células grandes, adenocarcinoma, epidermoide y de células pequeñas, aunque es mayor en los dos últimos. En los hombres fumadores el 
riesgo de padecer esta enfermedad es hasta 20 veces mayor que para los no fumadores 79.

En España, el cáncer de pulmón representa la principal causa de muerte por cáncer en varones, provocando 14.000 muertes en el año $1998^{64}$. Se ha establecido una clara relación dosis/respuesta en las siguientes variables relacionadas con el hábito tabáquico:

a) Número de cigarrillos consumidos: la relación no es lineal, ya que los fumadores de 40 cigarrillos/día tienen un riesgo más de dos veces superior a los fumadores de 20 cigarrillos/día.

b) Duración del consumo: el riesgo es mayor consumiendo 20 cigarrillos/día durante 40 años que fumando 40 cigarrillos/día durante 20 años.

c) Edad de comienzo: El riesgo de los fumadores que comenzaron antes de los 15 años es 4 veces mayor que aquellos que lo hicieron después de los 25 .

d) Tipo de cigarrillo y grado de inhalación: el riesgo es mayor en los que inhalan más profundamente y consumen cigarrillos con un contenido más alto de nicotina y alquitranes ${ }^{90}$, si bien aquellos fumadores de cigarrillos con un contenido bajo en nicotina y alquitrán precisan fumar más para mantener los niveles de nicotina en sangre, incrementando de esta manera la exposición a los carcinógenos del tabaco.

e) Abandono del tabaquismo: el riesgo disminuye en gran medida tras 10 a 15 años de dejar de fumar, aunque nunca llega a igualarse al de un no fumador. El riesgo disminuye mucho más en fumadores leves y moderados ${ }^{91}$.

Es importante incidir en la idea de que no todos los fumadores tienen el mismo riesgo carcinogénico, puesto que solo 1 de cada 10 fumadores desarrollarán cáncer de pulmón, y hay grandes fumadores que son muy longevos. Por tanto la variación interindividual producida por las diferentes susceptibilidades relacionadas con los 
metabolismos de los carcinógenos, la reparación del DNA o ambos, es importante para el riesgo de desarrollar cáncer ${ }^{92}$.

\subsubsection{5.- Patología derivada del tabaquismo pasivo.}

El tabaquismo pasivo fue definido en 1986 como la exposición de no fumadores a los productos de la combustión del tabaco en espacios cerrados ${ }^{93}$. El mayor riesgo se da en aquellas personas que viven con fumadores, donde fumar esta permitido en el hogar, en los cuales los niveles séricos de cotina, metabolito de la nicotina, están elevados y se correlacionan con el número de cigarrillos fumados ${ }^{94}$. Tras el tabaquismo activo y el alcoholismo, representa la tercera causa de muerte evitable en los países desarrollados 95. Numerosos estudios han documentado el riesgo para la salud que supone el tabaquismo pasivo $93,94,96-98$. De las principales enfermedades relacionadas con la exposición al humo de tabaco ambiental en población adulta (Tabla 5) destaca el cáncer de pulmón, existiendo estudios que han demostrado un incremento de riesgo de padecer cáncer de pulmón en mujeres no fumadoras de maridos que eran fumadores ${ }^{98}$. Este aumento de riesgo es de cuantía moderada, no pudiendo ser atribuido a los factores de confusión potencialmente existentes en los diferentes estudios o a errores en la clasificación de los pacientes. Un reciente Meta- análisis con estudios realizados en diferentes continentes ha corroborado esta relación ${ }^{99}$.

Debido a esta causa, cada año mueren en EE.UU 53.000 personas, en Europa 22.000 y en España la cifra de fallecimientos por la exposición pasiva al humo del tabaco es cercana a las 5.000 personas ${ }^{95}$. 
Tabla 5. Enfermedades más frecuentes relacionadas con el tabaquismo pasivo.

\begin{tabular}{||rl||}
\hline$\checkmark$ & Cáncer de pulmón \\
$\checkmark$ & Otras neoplasias relacionadas: \\
& - Células escamosas de cabeza y cuello, senos maxilares \\
& $\bullet$ Carcinoma nasofaríngeo \\
& $\bullet$ Cáncer de cuello uterino \\
& $\bullet$ Cáncer de vejiga \\
& $\bullet$ Cáncer de estómago \\
$\checkmark$ & Neoplasias relacionadas (datos aún insuficiente): \\
& $\bullet \quad$ Cáncer de mama. \\
\hline$\checkmark$ & Enfermedades cardiovasculares \\
\hline$\checkmark$ & Asma bronquial \\
\hline$\checkmark$ & EPOC \\
\hline$\checkmark$ & Síntomas respiratorios agudos y crónicos \\
\hline
\end{tabular}

\section{4.- Manifestaciones clínicas.}

Los signos y síntomas del cáncer de pulmón van a depender tanto de la localización del tumor, como de la extensión locorregional, la diseminación a distancia y la aparición de síndromes paraneoplásicos.

\subsection{1.- Manifestaciones debidas al tumor}

Los tumores que aparecen en la vía aérea producen síntomas relacionados con el crecimiento del tumor. Entre los síntomas más frecuentes encontramos disnea, tos persistente, hemoptisis, sibilancias y estridor. Si el tumor obstruye el bronquio puede aparecer una zona atelectásica con sobreinfección distal en forma de neumonía o absceso. 


\subsection{2.- Manifestaciones debidas a la extensión locorregional.}

La clínica depende de la estructura afectada (ganglios linfáticos, nervios, pleurapared torácica, vascular- cardiaca o visceral)

En tumores apicales aparece el Síndrome de Pancoast con afectación del plexo braquial, Síndrome de Horner y dolor en el hombro. Cuando hay afectación linfática mediastínica puede haber compresión de nervios como el frénico, el vago o el recurrente, con sus correspondientes manifestaciones. El síndrome de vena cava superior, producido por compresión mediastínica tumoral ó más raramente por trombosis, produce plétora facial y congestión de las venas del cuello y el torso. La afectación pleural puede ser directa o por diseminación linfática retrógrada apareciendo el típico dolor pleurítico y disnea.

El pericardio puede afectarse por invasión directa o por diseminación metastásica apareciendo signos de derrame pericárdico y en ocasiones taponamiento cardiaco. La disfagia es un síntoma muy poco frecuente y puede ser debido a infiltración de la pared del esófago por el tumor ó por parálisis del nervio recurrente.

\subsection{3.- Manifestaciones de la enfermedad a distancia.}

Un tercio de los pacientes presentan síntomas por afectación metastásica en el momento del diagnóstico. El carcinoma de células pequeñas y los poco diferenciados son los que con más frecuencia dan metástasis a distancia.

Los lugares más frecuentes de metastatización son la pleura, el pulmón, el hueso, el cerebro, el pericardio y el hígado. El 20\% de los enfermos, preferentemente aquellos con carcinoma de células pequeñas, presenta metástasis cerebrales durante su evolución y estas suelen ser de localización frontal. La afectación hepática y suprarrenal suelen indicar un estadio evolucionado de la enfermedad. 


\subsection{4.- Síndromes paraneoplásicos.}

El cáncer de pulmón es el tumor que con mayor frecuencia produce síndromes paraneoplásicos, siendo el principal responsable el carcinoma de células pequeñas.

La sintomatología es muy variada y depende del tipo de polipéptido secretado. Así, podemos encontrar síndromes endocrinos, neurológicos, hematológicos, esqueléticos, cutáneos, etc.., pudiendo ser en ocasiones la primera manifestación de la enfermedad.

\section{5.- Estadificación y diagnóstico.}

La clasificación del cáncer de pulmón no microcítico se realiza utilizando la clasificación de la International Union Against Cancer (UICC) del 2002. Esta clasificación se divide en $\mathrm{T}, \mathrm{N}$ y $\mathrm{M}$. T evalua el tumor primario, $\mathrm{N}$ la afectación ganglionar y M la existencia de metástasis a distancia (Tablas 6 y 7). El cáncer de pulmón microcítico no se clasifica según la clasificación TNM de la Unión Internacional contra el Cáncer sino que se divide en Enfermedad Limitada y Enfermedad Diseminada según la clasificación del grupo de Veteranos Americanos, siendo la enfermedad Limitada aquella que es incluible en un campo de irradiación. 


\section{Tabla 6. Clasificación TNM para el Carcinoma no Microcítico de Pulmón.}

Clasificación de la International Union Against Cancer (UICC), 2002

\begin{tabular}{||l|l||}
\hline Tx & $\begin{array}{l}\text { El tumor primario no se puede valorar o el tumor se ha demostrado a través de la presencia } \\
\text { de células malignas en el esputo o en lavados bronquiales, pero no se ha podido visualizar } \\
\text { por imágenes o endoscópicamente. }\end{array}$ \\
\hline T0 & No hay evidencia de tumor primario. \\
\hline Tis & Carcinoma in situ. \\
\hline T1 & $\begin{array}{l}\text { Tumor de diámetro menor o igual a } 3 \mathrm{~cm} \text {, rodeado por pulmón o pleura visceral, sin evidencia } \\
\text { broncoscopica de invasión más próxima que el bronquio lobar. }\end{array}$ \\
\hline T2 & $\begin{array}{l}\text { Tumor con cualquiera de las siguientes características en tamaño o extensión: Mayor de } 3 \mathrm{~cm} \\
\text { de diámetro máximo, Invasión del bronquio principal a una distancia a la carina mayor o o } \\
\text { ingual a } 2 \text { cm, Invasión de la pleura visceral, Asociación a atelectasia o pneumonitis } \\
\text { obstructiva con extensión a la región del hilio, pero sin afectar a la totalidad del pulmón. }\end{array}$ \\
\hline T3 & $\begin{array}{l}\text { Tumor de cualquier tamaño que invada directamente algún órgano o estructura de los } \\
\text { siguientes: pared torácica, diafragma, pleura mediastínica, pericardio parietal; o tumor del } \\
\text { bronquio principal a una distancia menor de } 2 \text { cm de la carina pero sin afectarla; o atelectasia o } \\
\text { pneumonitis asociada que afecte a la totalidad del pulmón. }\end{array}$ \\
\hline T4 & $\begin{array}{l}\text { Tumor de cualquier tamaño que invada directamente algún órgano o estructura de los } \\
\text { siguientes: mediastino, corazón, grandes vasos, tráquea, esófago, cuerpo vertebral, carina, } \\
\text { nódulo tumoral secundario en el mismo lóbulo; tumor con efusión pleural maligna. }\end{array}$ \\
\hline
\end{tabular}

\section{T- Tumor primario}

\begin{tabular}{|c|l||}
\hline $\mathbf{N x}$ & Los ganglios linfáticos regionales no se pueden evaluar. \\
\hline N0 & No hay evidencia de metástasis en los ganglios linfáticos regionales \\
\hline N1 & $\begin{array}{l}\text { Metástasis en los ganglios hiliares y/o peribronquiales homolaterales, y/o en los ganglios } \\
\text { intrapulmonares, incluyendo la extensión directa. }\end{array}$ \\
\hline N2 & Metástasis en ganglios medistínicos homolaterales y/o subcarinales. \\
\hline N3 & $\begin{array}{l}\text { Metástasis en los ganglios mediastínicos y/o hiliares contralaterales, y/o en los escalenos y/o } \\
\text { supraclaviculares homo o contralaterales. }\end{array}$ \\
\hline \hline
\end{tabular}

\section{N- Ganglios linfáticos regionales}

Estudio de los polimorfismos de genes reparadores en población fumadora con y sin cáncer de pulmón 


\begin{tabular}{|c|l||}
\hline Mx & Las metástasis a distancia no se pueden valorar. \\
\hline M0 & No hay evidencia de metástasis a distancia. \\
\hline M1 & $\begin{array}{l}\text { Metástasis a distancia incluyendo nódulos tumorales separados, situados en lóbulos } \\
\text { diferentes al tumor primario (homo o contralateral) }\end{array}$ \\
\hline
\end{tabular}

M- Metástasis a distancia

Tabla 7. Agrupación por Estadios del Cáncer no Microcítico de Pulmón

\begin{tabular}{|c|c|c|c|}
\hline Carcinoma oculto & $\mathrm{Tx}$ & No & MO \\
\hline Estadio 0 & Tis & No & $\mathrm{MO}$ \\
\hline Estadio IA & $\mathrm{T} 1$ & No & $\mathrm{MO}$ \\
\hline Estadio IB & $\mathrm{T} 2$ & No & MO \\
\hline Estadio IIA & $\mathrm{T} 1$ & N1 & $\mathrm{MO}$ \\
\hline Estadio IIB & $\begin{array}{l}\mathrm{T} 3 \\
\mathrm{~T} 2\end{array}$ & $\begin{array}{l}\text { N0 } \\
\text { N1 }\end{array}$ & MO \\
\hline Estadio IIIA & $\begin{array}{c}\mathrm{T} 1, \mathrm{~T} 2 \\
\mathrm{~T} 3\end{array}$ & $\begin{array}{c}\mathrm{N} 2 \\
\mathrm{~N} 1, \mathrm{~N} 2\end{array}$ & MO \\
\hline Estadio IIIB & $\begin{array}{c}\text { Cualquier T } \\
\text { T4 }\end{array}$ & $\begin{array}{c}\mathrm{N} 3 \\
\text { Cualquier N }\end{array}$ & MO \\
\hline Estadio IV & Cualquier $\mathrm{T}$ & Cualquier $\mathrm{N}$ & M1 \\
\hline
\end{tabular}

La realización de una historia clínica minuciosa y un examen físico detallado es fundamental para orientar el diagnóstico clínico.

Las principales exploraciones complementarias utilizadas en el diagnóstico del tumor primario son:

\section{a) Radiografía de tórax.}

Suele ser la técnica inicial que hace sospechar el diagnóstico. Los signos radiológicos más comunes derivan de la afectación de la vía aérea principal, 
apareciendo ensanchamiento hiliar y atelectasia. El tipo histológico puede ser intuido en función del patrón radiológico: el carcinoma epidermoide suele aparecer como una masa central de gran tamaño, a menudo cavitada. El adenocarcinoma se manifiesta frecuentemente como un nódulo o masa de distribución periférica. El carcinoma microcítico presenta una localización perihiliar en el $80 \%$ de los casos y se asocia a adenopatías mediastínicas.

\section{b) Citología de esputo.}

Tiene una alta rentabilidad en las tumoraciones de localización central, debiéndose analizar un mínimo de 4 muestras diferentes para alcanzar la máxima rentabilidad diagnóstica.

\section{c) Fibrobroncoscopia.}

Proporciona el diagnóstico específico en el $70 \%$ de los casos, elevándose al 95\% en los casos en los que se visualiza la tumoración. En los tumores periféricos y en la linfangitis carcinomatosa es adecuado realizar biopsia transbronquial y lavado broncoalveolar.

\section{d) Punción pulmonar transparietal.}

Es la técnica de elección en los nódulos periféricos, en los que con frecuencia la fibrobroncoscopia ó el análisis de esputo no aportan el diagnóstico, con una sensibilidad y un valor predictivo positivo superior al $90 \%$.

En cuanto a las pruebas utilizadas en el diagnóstico de extensión, cabe destacar:

\section{a) Tomografía Axial Computerizada (TAC).}

Es la técnica de elección para evaluar la tumoración y su extensión intratorácica, al mostrar lesiones milimétricas indetectables por la radiografía y 
definir las características anatómicas del tumor. Igualmente se ha sugerido como screening en población de riesgo para detectar tumores en estadios precoces ${ }^{100}$.

\section{b) Tomografía por emisión de positrones ( PET ).}

Está indicado en los pacientes candidatos a cirugía para el estudio de adenopatías mediastínicas, donde la sensibilidad y especificidad de esta técnica es del $80 \%$, y para el rastreo de posibles metástasis a distancia no evidenciadas en la $\mathrm{TAC}^{101}$.

\section{c) Otras técnicas diagnósticas.}

La mediastinoscopia está indicada para evaluar la afectación mediastínica inoperable detectada por la TAC ó el PET. En el caso de sospecha de afectación metastásica de órganos como hígado, hueso, o glándula suprarrenal, la realización de biopsia para confirmar la existencia de invasión tumoral nos puede aportar el diagnóstico y el grado de extensión de la enfermedad. En el carcinoma de células pequeñas, dada su capacidad de diseminación a distancia, el estudio de extensión debe incluir un TAC cerebral y una gammagrafía ósea. 


\section{6.- Factores Pronósticos.}

\subsection{1.- Cáncer de pulmón no microcítico.}

\subsubsection{1- Estadios precoces (Estadio I, II y III resecable)}

El factor pronóstico más importante es el tamaño tumoral y la presencia ó ausencia de diseminación ganglionar ${ }^{102}$. La edad mayor a 60 años y el sexo masculino o la realización de una cirugía distinta a la lobectomía o la neumonectomía también se han asociado a un peor pronóstico ${ }^{103}$. Igualmente la expresión de mucina se ha asociado a un pronóstico desfavorable ${ }^{104-106}$. Una variedad de nuevos factores pronósticos han aparecido con el aumento de la disponibilidad de sofisticadas pruebas moleculares, cómo la activación de Oncogenes ( RAS, MYC, C-ERB B-2, BCL2 ) o la perdida de genes supresores de tumores ( RB, p53, p16 $)^{104,106-109}$. Así mismo, los pacientes con tumores diploides sobreviven más que aquellos con tumores aneuploides ${ }^{108,110,111}$.

\subsubsection{Estadios avanzados (Estadio III no resecable y estadio IV)}

Los factores pronósticos más importantes son el estadio antes del tratamiento, el estado general y la pérdida de peso. Las metástasis medulares y hepáticas se han asociado como un predictor de corta supervivencia.

\subsubsection{Cáncer de pulmón microcítico.}

El factor pronóstico más importante es el estadio, siendo el pronóstico mucho más favorable en aquellos pacientes con enfermedad limitada a un hemitórax, lo que sólo ocurre en un $30-40 \%$ de los casos ${ }^{112}$. Los valores elevados de LDH al diagnóstico, enolasa neuroespecífica, así como un mal estado general se asocian también a un mal pronóstico ${ }^{113-117}$. 


\section{7.- Tratamiento}

\subsubsection{Cáncer de pulmón no microcítico.}

El tratamiento a elegir en los pacientes con carcinoma no microcítico de pulmón depende del estadio inicial de la enfermedad, variando este desde la cirugía en los estadios iniciales localizados, a la quimioterapia, radioterapia ó ambas en los estadios avanzados.

\subsubsection{1.- Cirugía.}

Es el tratamiento de elección en los pacientes con estadios I y II que toleren la intervención, con una supervivencia global a los 5 años entre el 35 y el $80 \%{ }^{5}$. La lobectomía es preferible a la neumonectomía siempre que la resección quirúrgica sea completa, pues las supervivencias son similares y la morbilidad menor con la lobectomía ${ }^{118}$. No se recomiendan resecciones limitadas (resección en cuña, segmentectomía) pues se acompañan de más recaídas locorregionales que la lobectomía. ${ }^{119}$. Ambas técnicas deben acompañarse de linfadenectomía mediastínica ${ }^{120,}$ 121.

En el estadio IIIA el papel de la cirugía tras la quimioterapia es controvertido, y en el estadio IIIB por N3 ó por afectación de estructuras vitales no está indicada salvo algunos pacientes en estadio T4 por invasión de la aurícula izquierda, donde la cirugía aumenta la supervivencia a los 5 años hasta el $22 \%{ }^{10}$.

En los pacientes con tumores resecables y metástasis cerebral, suprarrenal o pulmonar única, debe valorarse la resección quirúrgica de la metástasis.

\subsubsection{2.- Radioterapia.}

Existen varias modalidades de tratamiento radioterápico: de modo adyuvante tras la cirugía si los márgenes son positivos o hay afectación ganglionar N2; directamente 
sobre el tumor primario en Estadios I y II inoperables, IIIA irresecables o IIIB asociados a quimioterapia; con fines paliativos, para el tratamiento de metástasis cerebrales, compresión medular, hemoptisis, síndrome de vena cava superior, dolor óseo secundario a metástasis óseas, etc...

\subsubsection{3.- Quimioterapia.}

Numerosos estudios randomizados y metanálisis demuestran que el tratamiento quimioterápico aumenta la supervivencia y mejora la calidad de vida en el cáncer de pulmón metastático ${ }^{122-130}$. Igualmente se ha demostrado su beneficio como tratamiento adyuvante tras la cirugía de tumores resecados en estadio II-IIIA ${ }^{131}$. De entre los muchos fármacos empleados en el cáncer de pulmón, los más activos son los derivados del platino, como el Cisplatino y el Carboplatino. Otros fármacos muy eficaces son los agentes antimicrotúbulos, como el Paclitaxel y el Docetaxel, la Vinorelbina, Gemcitabina, Pemetrexed, Irinotecán, etc... empleándose en la mayoría de los casos en asociación con los derivados del platino en forma de combinación de dos fármacos ${ }^{132}$, 133. Con esta estrategia terapéutica, la mediana de supervivencia en la enfermedad metastásica es de aproximadamente 10 meses, la supervivencia al año del 40\%, y a los 2 años del $20 \%{ }^{10}$.

A los pacientes que no responden al tratamiento inicial y tienen un buen estado general, debe de ofrecérseles una segunda línea de tratamiento, siendo los fármacos estándars el Docetaxel y el Pemetrexed ${ }^{134,135}$.

El descubrimiento de importantes respuestas y mejoras en la supervivencia en pacientes con mutaciones en el gen del receptor del factor de crecimiento epidérmico ${ }^{136}$ que son tratados con inhibidores de la tyrosin kinasa han permitido la utilización de nuevos agentes terapéuticos como erlotinib o genitinib ${ }^{137}$. La utilización de vacunas usando células antólogas tumorales genéticamente modificadas con factores estimulantes de colonias, constituyen una nueva opción terapeútica en pacientes con NSCLC avanzado quimioresistente ${ }^{138,139}$. 
Actualmente, las nuevas líneas de investigación que se están llevando a cabo en cáncer de pulmón tienen por objetivo personalizar el tratamiento en función de las variables genéticas que presentan los pacientes. Se están realizando estudios con análisis genómico, intentando delimitar cuales son los pacientes que obtienen un mayor beneficio terapéutico en función de diferentes parámetros biológicos, basados en el análisis molecular de polimorfismos genéticos.

Se han descubierto marcadores genéticos en ADN de sangre periférica que pueden ser útiles para predecir la respuesta y supervivencia a combinaciones específicas de citostáticos (quimioterapia). Mediante el análisis de la presencia de determinados polimorfismos en sangre periférica se podría saber la causa de las diferencias en la respuesta a cada terapia según el paciente. Con ello se facilitará la elección del tratamiento más indicado, logrando mejoras en la supervivencia y en la calidad de vida 140. En este sentido recientes estudios han demostrado que polimorfismos en el gen reparador de tumores ERCC1 modifican la respuesta de los pacientes al tratamiento con cisplatino ${ }^{141}$.

\subsection{2.- Cáncer de pulmón microcítico.}

La mediana de supervivencia de los pacientes con carcinoma microcítico de pulmón sin tratamiento es de sólo 6-18 semanas. La adecuada combinación de la quimioterapia y radioterapia son la base del tratamiento.

\subsubsection{1.- Enfermedad limitada.}

La cirugía está indicada en casos muy seleccionados y el tratamiento se basa en la administración de radioterapia torácica de forma concomitante con regimenes de quimioterapia basados en Cisplatino y Etopósido, logrando hasta un 50\% de remisiones completas y una supervivencia a los 5 años del 20-25\% 142, ${ }^{143}$. La administración de radioterapia hiperfraccionada ha conseguido mejores resultados que el fraccionamiento convencional pero a costa de una mayor toxicidad ${ }^{144}$. En los pacientes con remisión 
completa está indicada la irradiación craneal profiláctica al disminuir la incidencia de metástasis cerebrales y aumentar la supervivencia ${ }^{145,146}$.

\subsubsection{2.- Enfermedad diseminada.}

El tratamiento de elección es la poliquimioterapia con derivados del platino y Etopósido, con unas tasas de respuesta global del 60-80\% y una mediana de supervivencia de 7 a 12 meses ${ }^{147-149}$. En la población japonesa la combinación del platino con CPT-11 fue superior al estándar platino-etopósido, pero no así en la población americana, lo cual puede indicar la influencia racial de los diferentes polimorfismos en el metabolismo de los fármacos empleados en su tratamiento ${ }^{150},{ }^{151}$. En los pacientes en que se consigue una respuesta completa al tratamiento quimioterápico inicial está también indicada la irradiación craneal profiláctica al disminuir la incidencia de metástasis cerebrales y aumentar la supervivencia ${ }^{146}$. 


\section{2.- Biología molecular y genética del cáncer: Aspectos generales.}

El cáncer es una enfermedad producida por una serie de cambios en el genoma resultado de la interacción entre factores exógenos y endógenos, cuyo efecto final es la transformación de las células normales en cancerígenas. El cáncer es, por tanto, una enfermedad genética. Se denominan carcinógenos a los agentes externos que originan mutaciones en el genoma. Dada la heterogeneidad de la población, la susceptibilidad al daño para una misma exposición es diferente entre los distintos individuos, jugando un papel muy importante en está interacción la variabilidad genética.

Desde un enfoque biológico, las células cancerosas se caracterizan por presentar un crecimiento incontrolado, perder la diferenciación y tener capacidad de difundir invadiendo los tejidos vecinos originando metástasis. Seis son las alteraciones aceptadas en la fisiología celular responsables del fenotipo de la célula cancerosa ${ }^{152}$ :

\section{I.- Autosuficiencia en las señales de crecimiento.}

Las células requieren una serie de señales de crecimiento para pasar de la fase quiescente o G0 a la fase G1 del ciclo celular. Estas señales, pasan al espacio intracelular mediante receptores transmembranales y se unen a moléculas señalizadoras, como los factores de crecimiento difusibles, componentes de matriz extracelular, y moléculas de adherencia/interacción célula-célula. En este sentido, las células tumorales generan sus propias señales de crecimiento disminuyendo la dependencia de la estimulación exógena del crecimiento por el microambiente del tejido normal, rompiendo la homeostasis necesaria para el funcionamiento celular normal dentro de un tejido. Las células cancerosas adquirirían así la capacidad de sintetizar factores de crecimiento que autoestimularían a las mismas, creando una retroalimentación positiva en el círculo de señalización, denominada estimulación autocrina, perdiendo la dependencia exocrina de las células sanas ${ }^{153}$.

\section{II.- Insensibilidad a las señales inhibitorias del crecimiento.}


En el mantenimiento de la quiescencia celular y la homeostasis tisular participan múltiples señales antiproliferativas. Entre ellas debemos incluir factores solubles y otros existentes en la matriz extracelular. Estas señales pueden inhibir el crecimiento haciendo que las células entren en estado G0 del ciclo celular, manteniéndolas en estados postmitóticos. La mayoría de las proteínas responsables de esta función están asociadas con el ciclo celular $\mathrm{y}$, a nivel molecular, casi todas las señales antiproliferativas implican a la proteína del retinoblastoma $(\mathrm{pRb})$, de manera que, cuando está hipofosforilada, bloquea la proliferación secuestrando la proteína E2F, un factor de trascripción que controla genes, como myc, esenciales para la transición de la fase G1 a fase $\mathrm{S}$ del ciclo celular. La alteración del gen Rb, libera E2F y favorece la proliferación celular. La pérdida de función de otros genes supresores de tumores implicados en el control del ciclo celular como p15 y p16, también favorecerían la adquisición de esta capacidad por las células tumorales ${ }^{152}$.

\section{III.- Pérdida de la apoptosis o muerte celular programada.}

El crecimiento tumoral está determinado no sólo por el aumento de la capacidad de proliferación de las células tumorales, sino también por la tasa de muerte celular. La apoptosis representa la fuente principal de ésta muerte, y la resistencia adquirida a la apoptosis es un distintivo del proceso carcinogénico. La maquinaria apoptótica puede dividirse en dos tipos de componentes: a) proteínas que actúan como sensores, que reciben señales del interior celular o del medio ambiente extracelular, como los receptores para IGF e IL-3, que envían señales de supervivencia, o Fas y TNF alfa, que envían señales que inducen muerte celular. Estas señales acaban en la mitocondria, donde se procesan las señales proapoptóticas y se induce la liberación de citocromo $\mathrm{C}$; este proceso está regulado por los miembros de la familia de proteínas Bcl-2. La proteína p53 induce apoptosis regulando la expresión del gen Bax. b) proteínas efectoras, entre las que se encuentra un conjunto de proteasas intracelulares denominadas caspasas, que intervienen en la destrucción de las organelas celulares. Las células tumorales pueden adquirir resistencia a entrar en apoptosis por varios mecanismos, siendo el más común el asociado con la proteína p53 ${ }^{154}$, pero alteraciones 
en cualquiera de los genes que codifican proteínas implicadas en apoptosis pueden ser responsables de la aparición del fenotipo tumoral.

\section{IV.- Capacidad para reproducirse sin limitación.}

Las células poseen un programa intrínseco que permite limitar el número de veces que pueden dividirse y que opera de forma independiente de las señales intra $y$ extracelulares que regulan la proliferación celular. De esta manera, para que pueda expandirse un clon de células tumorales es necesaria la pérdida de esta limitación. Cuando las células no tumorales se cultivan "in vitro", alcanzado un cierto número de divisiones (entre 60 y 70) entran en un proceso de envejecimiento que les conduce a la muerte; este fenómeno, denominado senescencia, que no se observa en las células tumorales en cultivo, puede ser revertido mutando los genes Rb y p53. Otro mecanismo que limita el número de veces que pueden dividirse las células, se produce por el acortamiento de los telómeros debido a la pérdida de actividad de una enzima denominada telomerasa. Las células tumorales mantienen la actividad de la telomerasa, lo que facilita su proliferación ilimitada. Alteraciones en los genes que codifican estas proteínas se asocian con el desarrollo del fenotipo tumoral, adquiriendo la capacidad de multiplicarse ilimitadamente, proceso llamado inmortalización ${ }^{155}$.

\section{V.- Angiogénesis sostenida.}

Todas las células del organismo necesitan estar a una distancia mínima de 100 micras de un capilar sanguíneo para sobrevivir (debido a la necesidad de aporte de oxígeno y nutrientes). La organogénesis se asocia de manera indisoluble con la angiogénesis, que es resultado de un equilibrio entre estímulos favorables, como es la producción de factores solubles como VEGF y FGF1/2, que actúan sobre receptores tirosinakinasa de las células endoteliales estimulando su proliferación, y estímulos negativos como el mediado por la trombospondina-1. Otras proteínas, como las integrinas, implicadas en la interacción intercelular y con las células del estroma, realizan una importante función en el proceso de la vascularización. Hoy día está 
aceptado que, para que las células tumorales puedan expandirse, es necesario que controlen los mecanismos de angiogénesis, adquiriendo la capacidad para progresar a un mayor tamaño ${ }^{156}$, y dicha capacidad la adquieren durante la progresión tumoral como consecuencia de mutaciones en los genes encargados de regular este proceso.

\section{VI.- Difusión tumoral y metástasis.}

Durante su evolución, la mayoría de los tumores adquieren la capacidad no sólo de invadir los tejidos adyacentes, sino de escapar del tumor primario y colonizar nuevos sitios.

La invasión tisular y la metastatización son procesos extraordinariamente complejos cuyos determinantes genéticos y bioquímicos permanecen parcialmente comprendidos, y en los que están implicados diferentes proteínas que intervienen en la interacción con la matriz extracelular, como las integrinas ${ }^{157}$, la beta-catenina y la Ecadherina, cuya función se pierde en la mayoría de las células tumorales ${ }^{158}$, y proteasas degradadoras de la matriz extracelular como las metaloproteasas cuya alteración favorece la diseminación tumoral y sus inhibidores ${ }^{159-161}$. Alteraciones en los genes que codifican estas proteínas favorecen el crecimiento de la masa tumoral y la aparición de metástasis.

Existen igualmente factores de crecimiento y motilidad que juegan un papel muy importante en los mecanismos de migración a varios niveles de la cascada metastásica, actuando de manera autocrina o paracrina mediante la utilización de receptores específicos que median señales como la tirosin-fosforilación ${ }^{162,163}$.

En resumen, el cáncer es el resultado de la acumulación de alteraciones en genes que codifican proteínas involucradas tanto en el control de los mecanismos de proliferación y diferenciación celular, como en la interacción entre diferentes tipos celulares y con proteínas de la matriz extracelular. 


\section{3.- Biología molecular y genética del cáncer de pulmón.}

\section{1.- Protooncogenes en cáncer de pulmón.}

\subsection{1.- Genes de la familia de los receptores del factor de crecimiento.}

Los productos de los protoncogenes incluyen varios receptores de la familia de los factores de crecimiento, como el EGFR ${ }^{136}$, ERBB2, KIT y MET. Muchos de estos factores son expresados tanto por las células tumorales como por las células adyacentes normales, produciendo de este modo una estimulación autocrina y paracrina del crecimiento (figura 4).

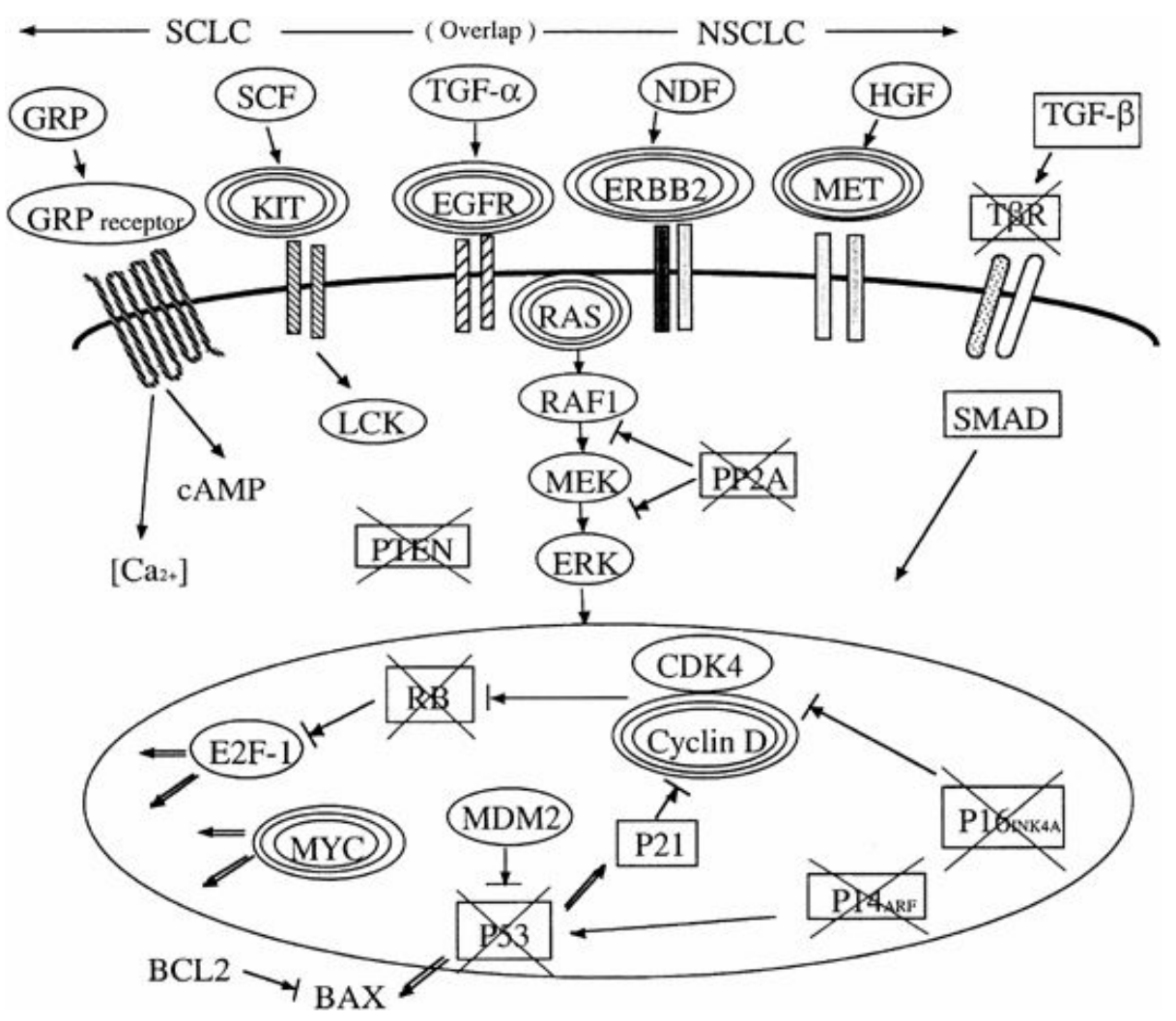

Figura 4. Fuente: Cancer: Principles and practice of Oncology, 6th Edition, edited by Vincent T. De Vita, Jr Samuel Hellman, Steven A. Rosenberg. 
La expresión aumentada de EGFR 1 codificada por el gen ERBB1 es más frecuente en el NSCLC que en el SCLC y se puede asociar al estadio y diferenciación tumoral. La expresión aumentada de EGFR y sus ligandos, especialmente el factor de crecimiento trasformador alfa (TGF-alfa), por las células tumorales indican la presencia de un factor autocrino estimulante de crecimiento. La expresión aumentada de EGFR ocurre en el 70\% de los NSCLC y la expresión aumentada de EGFR y TGF-alfa en un $38 \%{ }^{164}$. Clínicamente, el aumento de expresión de este factor autocrino estimulante TGF-alfa - no tiene impacto en la supervivencia global en los estadios iniciales, y parece que juega un papel en la formación del tumor más que en la progresión tumoral 164. ERBB2 (HER2/neu) está sobre expresado en más de un tercio de los NSCLC, especialmente en los adenocarcinomas, relacionándose con una mayor quimiorresistencia y una menor supervivencia ${ }^{165}$.

KIT y su ligando, el factor de "stem cell" (SCF) se hallan expresados en un gran porcentaje de SCLCs, facilitando un mayor crecimiento tumoral y una mayor quimiosensibilidad. MET y su ligando, el factor de crecimiento de los hepatocitos (HGF), está involucrado en el desarrollo pulmonar durante la etapa fetal, y su coexpresión se ha observado en la muchos NSCLCs, asociándose la presencia de niveles elevados de HGF con un peor pronóstico en pacientes con NSCLCs resecables ${ }^{136}$.

Aparte de los productos de los protooncogenes, otros factores estimulantes del crecimiento han sido identificados en el cáncer de pulmón, siendo el péptido liberador de gastrina (GRP) el mejor conocido, pudiendo representar en el futuro una buena diana terapeútica a la luz de los resultados de ensayos con Ac anti-GRP en pacientes tratados de SCLC ${ }^{166}$.

\subsection{2.- Genes de la familia RAS.}

Los genes de la familia RAS (KRAS, HRAS, y NRAS) pueden ser activados por mutaciones situadas en los codones 12, 13, o 61, y un miembro de esta familia está mutado en aproximadamente el 20-30\% de los NSCLC (particularmente los 
adenocarcinomas) pero probablemente nunca en el SCLC ${ }^{167}$. KRAS participa en el 90\% de las mutaciones en RAS en los adenocarcinomas de pulmón, afectando el $85 \%$ de las mutaciones al codon 12 . Habitualmente el $70 \%$ de las mutaciones de KRAS son transversiones de G a T, con la sustitución de una glicina (GGT) por una cistena (TGT) o una valina (GTT). Similares transversiones de G por T afectan al gen p53 en el cáncer de pulmón y representan el tipo de daño al DNA producido por los aductos causados por los hidrocarburos policíclicos y nitrosaminas del humo del tabaco. Este tipo de daño también está apoyado por la relación entre las mutaciones en KRAS y el consumo de tabaco.

La presencia de mutaciones en KRAS son una señal de mal pronóstico tanto en estadios tempranos como avanzados del NSCLC ${ }^{168}$, si bien los datos al respecto son algo conflictivos ${ }^{169}$. No obstante, un metanálisis realizado sobre ocho estudios que recogía 217 pacientes con NSCLC y mutaciones en KRAS sugirieron que los portadores de la mutación tenían un peor pronóstico ${ }^{170}$.

Un estudio prospectivo ha mostrado que ni la quimiosensibilidad ni la supervivencia se correlacionan con mutaciones en KRAS en adenocarcinomas de pulmón avanzados ${ }^{171}$. Otros genes de la familia RAS, como el protoncogen RAF1, no se han encontrado mutados en cáncer de pulmón, si bien moléculas por debajo de RAF1 en la cascada de transdución celular, como MEKK, MEK, y la proteinkinasa (MAPK/ERK), pueden estar ocasionalmente relacionadas con el proceso de carcinogénesis pulmonar ${ }^{172}$. El gen PPP2R1B, que codifica la isoforma beta de la proteinfosfatasa $2^{\mathrm{a}}$ (PP2A), la cual regula la cascada RAS/MAPK, se encuentra igualmente mutada en muy pocas ocasiones en el cáncer de pulmón ${ }^{173}$.

\section{2.- Genes supresores en cáncer de pulmón: El gen TP53}

El gen TP53 desempeña un papel fundamental en el desarrollo tumoral, pues se encuentra mutado en aproximadamente el 50\% de estos tumores ${ }^{174}$. 
Recibe este nombre porque codifica la proteína p53, fosfoproteína nuclear de 53 $\mathrm{KDa}$, que actúa sobre genes que codifican proteínas que regulan el ciclo celular, de forma que, en situaciones de daño al DNA, detiene el ciclo celular hasta que el DNA es reparado o hasta la muerte celular, evitando la proliferación de células mutadas ${ }^{175}$. Esta proteína funciona regulando la trascripción y modulando el ciclo celular en los puntos de control G1/S y G2/M, permitiendo detener el crecimiento celular y reparar el DNA ó activando la apoptosis si el daño es irreparable. La proteína p53 induce la detención del ciclo celular en múltiples puntos mediante la inducción de p21, inhibidor de la progresión del ciclo, y la inhibición catalítica de PCNA, proteína promotora de la replicación del DNA ${ }^{154,176}$. Así mismo, induce la trascripción de las proteínas encargadas de la reparación del DNA. La inactivación de la proteína se realiza por fosforilación dependiente de kinasas, su exclusión nuclear por mecanismos desconocidos y la formación de complejos con la proteína MDM-2, codificada por un proto-oncogén inducible por la proteína p53 ${ }^{175}$.

La mutación de una copia del gen TP53 y la deleción/inactivación del otro alelo origina la perdida de la función de la proteína p53. La mutación origina una proteína con cambio de conformación, una vida media más larga y una función desordenada ${ }^{177}$.

El gen TP53 está constituido por 393 codones distribuidos en 11 exones que ocupan cerca de $20 \mathrm{~kb}$ en el brazo corto del cromosoma 17(Figura 5). En el 13\% de los tumores las mutaciones se localizan en los codones 175, 248 y 273, que tienen un alto contenido en $\mathrm{CG}^{178}$.

TP53 (o P53) es el gen supresor de tumores más frecuentemente mutado en cáncer de pulmón (figura 6), estando presente su mutación en aproximadamente el $90 \%$ de los carcinomas microciticos de pulmón y el 50\% de los no microcíticos ${ }^{179,180}$. La mayoría de las mutaciones ocurren entre los exones 5 y 8 de p53, que corresponden con la región conservada filogenéticamente. 


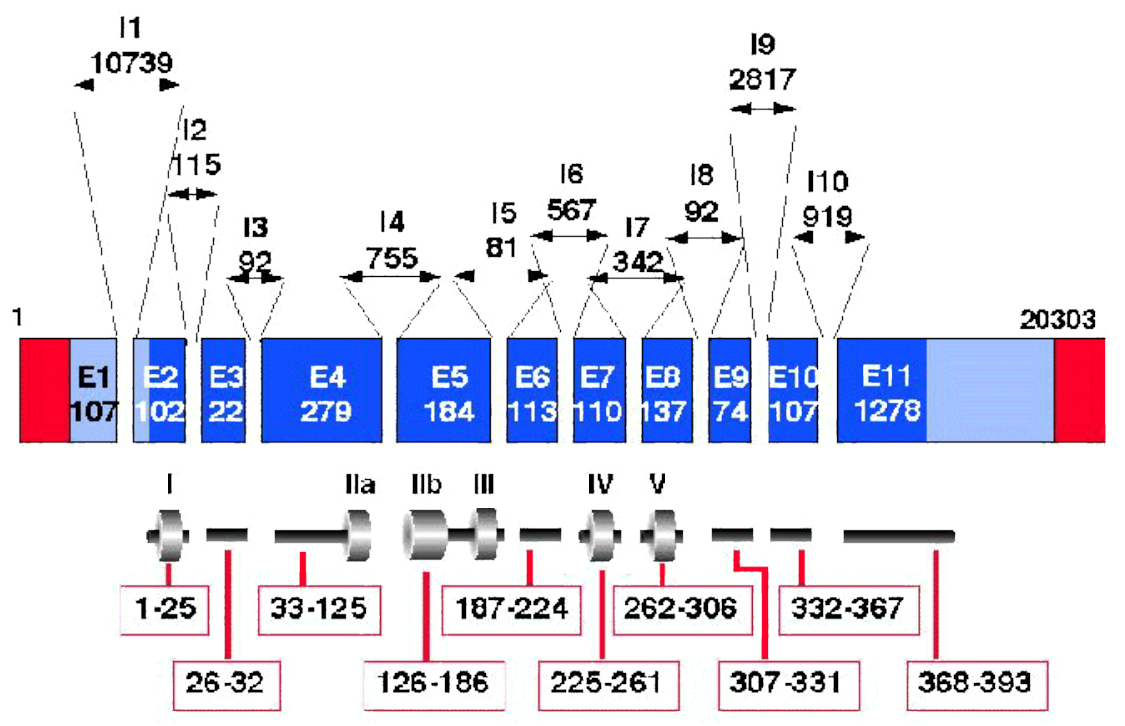

Figura 5. Organización del gen TP53. Los exones (E) están numerados progresivamente en la barra principal y los intrones (I) se magnifican como flechas.

Dentro del carcinoma no microcítico, las alteraciones de p53 ocurren con más frecuencia en el carcinoma escamocelular (51.2\%) y el carcinoma de célula grande $(53.7 \%)$ que en el adenocarcinoma $(38.8 \%)^{180}$. Las mutaciones en p53 se correlacionan con el consumo de tabaco y la mayoría son por transversiones de G por T por acción de los carcinógenos del tabaco, así como por la formación de aductos en puntos mutacionales conflictivos del p53 por acción de los benzoapirenos ${ }^{181}$.

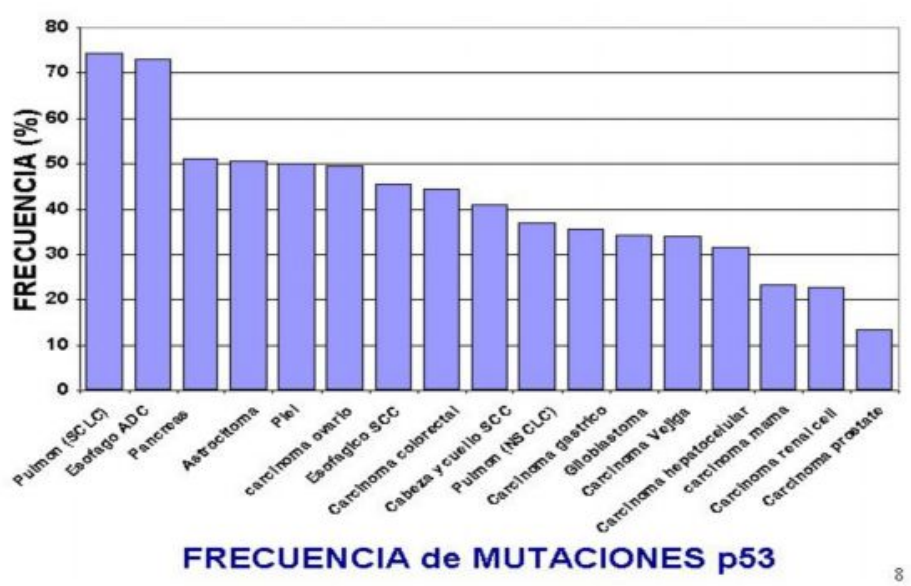

Figura 6. Frecuencia de mutaciones de p53 en los tumores más frecuentes. 
Aproximadamente el 15\% de los pacientes con cáncer de pulmón desarrollan Ac frente a la proteína del p53, incrementando la posibilidad de que la expresión aumentada de la proteína p53 mutada pueda producir una respuesta inmune humoral. Si bien los Ac anti p53 han sido propuestos como marcadores de diagnóstico temprano ${ }^{182} \mathrm{y}$ de respuesta a la quimioterapia ${ }^{183}$, el desarrollo de estos Ac no parece mejorar el pronóstico de la enfermedad ${ }^{184}$.

Se han realizado ensayos clínicos de terapia génica con resultados prometedores, obteniendo tasas de respuestas objetivas de aproximadamente un 10-15\%. En ellos se administran inyecciones intratumorales del gen p53 normal utilizando como vectores retrovirus ${ }^{185}$ o adenovirus ${ }^{186}$, y se están combinando con Quimio y radioterapia para comprobar si la terapia génica incrementa la sensibilidad de los tratamientos convencionales.

Mutaciones en otros genes supresores de tumores como p16, PTEN, FHIT, RARbeta, etc... también han sido implicados en la patogénesis del cáncer de pulmón ${ }^{5}$. 


\section{3.- Mutaciones en el gen TP53}

La inactivación del gen TP53 puede ocurrir por mutación, pérdida alélica, secuestro de la proteína mediante unión con productos virales, como las proteínas del adenovirus E1b y la proteína E6 del virus del papiloma humano, o por interacción con la proteína MDM2. Cuando la proteína p53 está inactivada, disminuyen los niveles de p21, lo que favorece que la proteína del retinoblastoma esté fosforilado y la célula pueda avanzar en el ciclo celular. Se han identificado aproximadamente 10.000 mutaciones del gen TP53 en tumores humanos ${ }^{187}$. La cuarta parte de estas mutaciones son sustituciones en pares de bases G:C. E1 87\% de las mutaciones caracterizadas se encuentran en los exones 5-8 y el 8\% en el exón 4. Las mutaciones en la región central del gen suelen ser del tipo "missense" -por cambio de sentido-, mientras que las que se producen en las regiones amino y carboxilo terminal, mucho menos frecuentes, suelen ser del tipo "nonsense" -producen un codón sin sentido-, mutaciones que cambian la fase de lectura, mutaciones en las secuencias de procesamiento o mutaciones silenciosas 188

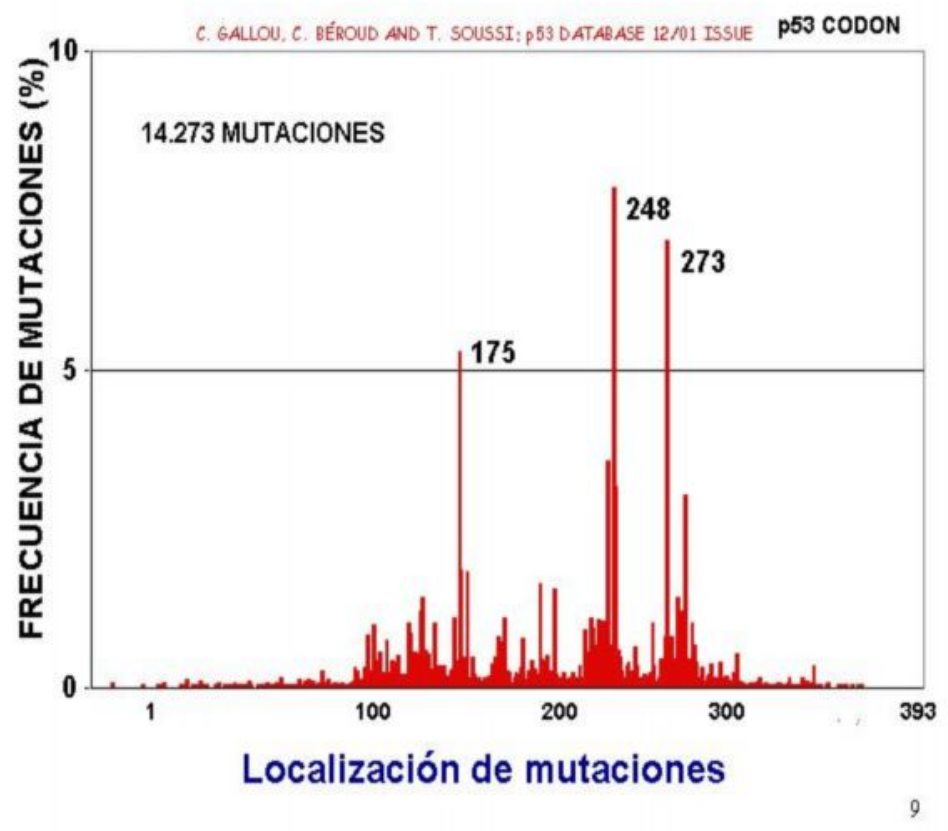

Figura 7. Localización y frecuencia de mutaciones en p53. 
Las mutaciones por cambio de sentido ("missense") pueden no sólo producir pérdida de la función supresora de tumores, sino favorecer funciones oncogénicas al modificar la expresión de genes que están controlados por este factor de trascripción, lo que se denomina efecto de ganancia de función ${ }^{189,190}$. La ganancia de función se consigue estimulando factores de crecimiento o receptores de factores de crecimiento, como el receptor del factor de crecimiento epidérmico ${ }^{136}$ y el factor de crecimiento vascular endotelial (VEGF). Otros genes que pueden aumentar su expresión cuando p53 está mutado son c-myc, c-fos, Il-6, isoformas de mdm2, MDR, etc ${ }^{175}$.

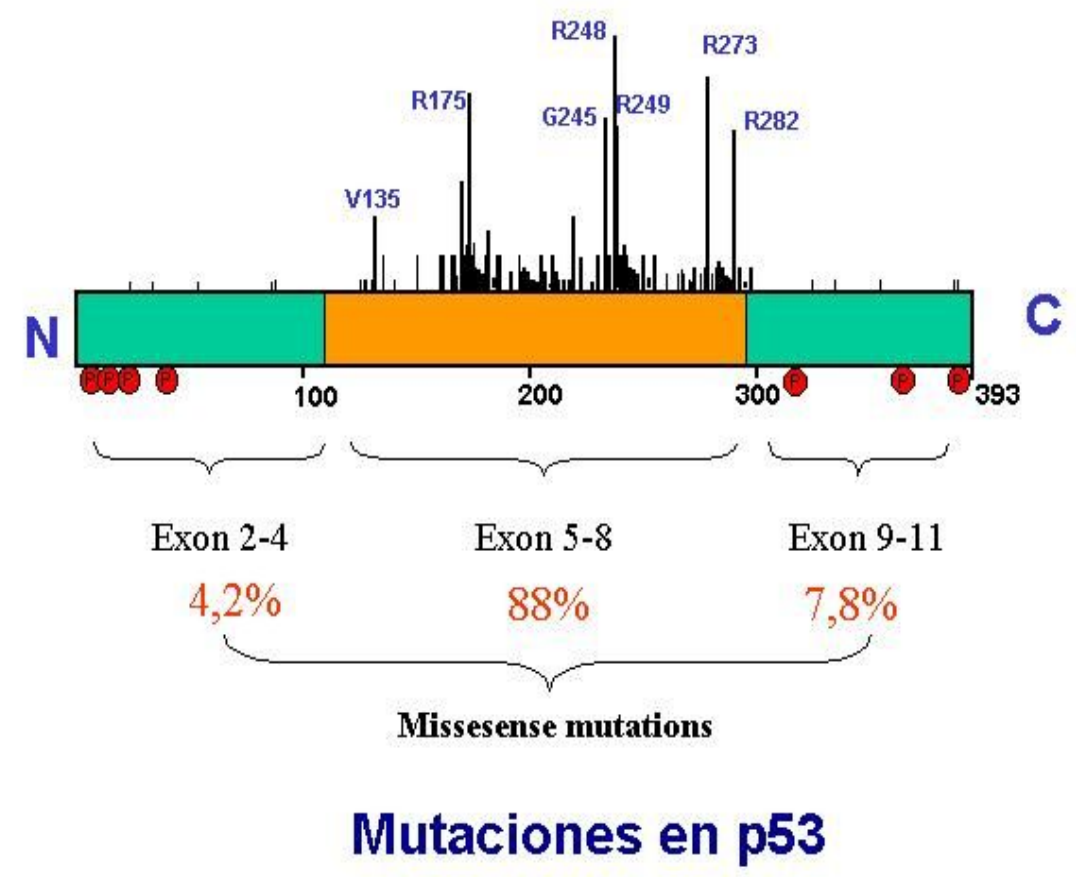

Figura 8. Principales localizaciones de las mutaciones Missesense en el gen p53.

Existen diferencias en el espectro mutacional de p53 entre distintas etnias, posiblemente debido a la exposición a carcinógenos específicos o a características heredadas por una población ${ }^{191,192}$. 


\section{4.- Genes reparadores del DNA}

El genoma humano, al igual que otros genomas, codifica información para proteger su propia integridad. Las enzimas reparadoras de DNA supervisan continuamente los cromosomas para corregir los daños en residuos de nucleótidos generados por la exposición a carcinógenos o a compuestos citotóxicos. Este daño es una consecuencia parcial del efecto de factores ambientales como la radiación ultravioleta solar, la inhalación del humo de cigarrillo o algunos factores aun no bien establecidos de la dieta. Sin embargo, una gran proporción de las alteraciones en el DNA son una causa inevitable de mutágenos endógenos como el agua oxigenada, las moléculas de oxigeno reactivas y ciertos metabolitos que actúan como agentes alquilantes. Estos daños en general causan una desestabilización en el DNA incluso en células que no proliferan. La inestabilidad genómica causada por la gran variedad de agentes tóxicos representaría un problema mayor para las células y los organismos en el caso de que no existieran los mecanismos de reparación del DNA.

Hasta el momento se han descrito más de 150 genes implicados en la reparación de DNA humanos ${ }^{193}$ y han sido identificados un gran numero de polimorfismos (SNPs) en genes de reparación de DNA ${ }^{194,195}$. La asociación entre los defectos en la reparación del DNA y el cáncer fue establecida en $1968{ }^{196}$ al demostrarse que el Xeroderma Pigmentosum (XP) es causado por una deficiente mecanismo de reparación por escisión de nucleótidos (NER). Durante más de un cuarto de siglo, tras este descubrimiento, se pensó que solo unos pocos síndromes raros como el de Ataxia telangiectasia, el XP o el síndrome de Cockaine se asociaban con estos defectos en la reparación del DNA ${ }^{197}$. Actualmente se están identificando continuamente polimorfismos en genes reparadores del DNA que tienen un papel principal en la carcinogénesis esporádica.

En mamíferos, las células han desarrollado en general cuatro mecanismos de reparación que incluyen más de 80 genes diferentes, que poseen una actividad directa en la reparación del daño en el DNA. Estos cuatro mecanismos junto con los genes claves de reconocimiento de daño en el DNA se relacionan con los genes de control del ciclo 
celular para retrasar la replicación y la división celular hasta que el nivel de daño en el DNA sea reducido.

I.- MMR( mismatch repair pathway) incluye por lo menos 6 genes y corrige principalmente nucleótidos que han sido erróneamente incorporados y que se generan durante la replicación del DNA primordialmente por la vía de recombinación no homologa. Sin embargo, su papel en la reparación de daños causados por exposición es limitada. Si estas lesiones no son reparadas se generan estructuras aberrantes generalmente bases únicas o en tandem que llegan a ser extrahelicas debido al mal alineamiento de las cadenas del DNA, causando incrementos o disminuciones hereditarias en la longitud de una determinada secuencia repetitiva. En genes de expresión, estos daños resultan en cambios en la fase de lectura y en la síntesis de proteínas inactivas y truncadas.

El reconocimiento de pequeños lazos generados por la inserción o pérdida de nucleótidos al igual que por las incorporaciones erróneas de bases (A:X) es realizado por un complejo denominado MUTS $\alpha$, un heterodimero de MSH2 y MSH6. Otro heterodimero MUTS $\beta$, que comprende el 10\% del MSH2 celular y MSH3 ${ }^{198}$, igualmente reconoce la formación de estas estructuras aunque tiene una mayor afinidad por estructuras más complejas como inserciones-pérdidas de 2-4 pares de bases. Un cierto grado de redundancia funcional entre los heterodímeros MUTS $\alpha$ y MUTS $\beta$ asegura que la corrección de todos los errores de replicación se inicie eficientemente a pesar de que la mayoría de ellos sean reconocidos por MUTS $\alpha$. Aunque el mecanismo de reconocimiento y reparación MMR no esta totalmente descrito, varios complejos proteicos que intervienen en este proceso han sido identificados, como MLH1, PMS2 y MLH3, que forman igualmente dos heterodímeros, MutL $\alpha$ y MutL $\beta$. Estos son reclutados al sitio de reparación tras interactuar con MSH2 y bajo la unión de ATP y/o hidrólisis. Adicionalmente otras proteínas implicadas en los subsecuentes pasos han sido identificadas: PCNA (proliferating cell nuclear antigen) actúa como enlace entre el complejo de MMR y la DNA polimerasa en la orquilla de replicación, posiblemente 
facilitando el reconocimiento y reparación de la nueva cadena. RFC (replication factor C) es un factor necesario para la unión de PCNA al DNA. Las exonucleasas EXOI/HEXI, FEN1 y las DNA polimerasas $\delta$ y $\varepsilon$ interactúan con MSH2 dirigiendo la escisión de las secuencias erróneas. Finalmente la resíntesis de la nueva cadena parece resultar tras la acción concertada de la DNA polimerasa $\delta$ y posiblemente de otras DNA polimerasas sensibles a la afidicolina. Las DNA ligasas que finalizan el mecanismo de reparación de MMR no han sido identificadas hasta el momento (Figura2).

II.- El mecanismo de reparación por escisión de bases (BER) implica 25 genes que procesan bases alteradas, pérdidas de bases y otros daños en su mayoría causados por radicales libres. La hidrólisis espontánea de residuos nucleótidos ocurre con bastante frecuencia a $37^{\circ} \mathrm{C}$, generando oxigeno reactivo y pequeñas moléculas intracelulares como la s-adenosilmetionina que causan lesiones en el DNA ${ }^{199}$. En general, lesiones en el DNA causadas por agentes endógenos son mayormente reparadas por esta ruta. Este proceso de reparación se inicia cuando una clase específica de enzima reparadora de DNA-DNA glicosilasa reconoce una base que ha sido alterada químicamente o que es inapropiada. La especificidad de substrato de cada una de las glicosilasas humanas actúa como indicador del daño causado (Tabla 8). Así, la uracil DNA-glicosilasa reconoce específicamente uracilo como la base incorrecta en el DNA y cataliza la hidrólisis del enlace N-glicosil que une la base y la estructura deoxiribosa-fosfato del DNA, dejando el sitio libre para la incorporación de la base correcta. 
Tabla 8. DNA Glicosilasas humanas y su especificidad enzimática (Modificado de Lindhal \& Wood, 1999) ${ }^{199}$.

\begin{tabular}{|c|c|c|c||}
\hline Enzima & $\begin{array}{c}\text { Tamaño } \\
\text { (residuos de aminoácidos) }\end{array}$ & $\begin{array}{c}\text { Localización } \\
\text { cromosómica del gen }\end{array}$ & $\begin{array}{c}\text { Base alterada removida } \\
\text { del DNA }\end{array}$ \\
\hline UNG & 313 & $12 \mathrm{q} 23-\mathrm{q} 24$ & U y 5-hidroxiuracilo \\
\hline TDG & 410 & $12 \mathrm{q} 24.1$ & $\begin{array}{c}\text { U o T opuesto a G, } \\
\text { etenocitosina }\end{array}$ \\
\hline hSMUG1 & 270 & $12 \mathrm{q} 13.1-\mathrm{q} 14$ & $\begin{array}{c}\text { U( preferiblemente de DNA } \\
\text { de cadena única) }\end{array}$ \\
\hline MBD4 & 580 & $3 \mathrm{q} 21$ & $\begin{array}{c}\text { U o T opuesto a G en } \\
\text { secuencias CpG }\end{array}$ \\
\hline hOGG1 & 345 & $1 \mathrm{p} 32.1-\mathrm{p} 34.3$ & $\begin{array}{c}\text { 8-oxo G opuesto a C, } \\
\text { formamidopirimidina }\end{array}$ \\
\hline MYH & 521 & $16 \mathrm{p} 13.2-\mathrm{p} 13.3$ & $\begin{array}{c}\text { A opuesto a 8-oxo G } \\
\text { dimina glicol, citosina glicol, } \\
\text { dihidrouracilo, } \\
\text { formamidopirimidina }\end{array}$ \\
\hline telómero $)$ & $\begin{array}{c}\text { 3-MeA, etenoadenina, } \\
\text { hipoxantina. }\end{array}$ \\
\hline \hline
\end{tabular}

Las DNA glicosilasas humanas poseen un dominio catalítico de hasta 250 residuos de amino ácidos y utilizan una región terminal $\mathrm{NH}_{2}$ o $\mathrm{COOH}$ que permiten interacciones adicionales con la cadena complementaria. La DNA glicosilasa permanece entonces anclada al sitio de daño hasta ser desplazada por la endonucleasa APE1(o HAP1), que tiene una mayor afinidad por los sitios abásicos. Esta estrategia protege los residuos abásicos de la transformación de la deoxiribosa en un aldehído reactivo que podría causar entrecruzamiento además de otros efectos nocivos en el DNA. La unión de APE1 al DNA induce la interacción de esta proteína con la siguiente enzima en el proceso de BER, POL $\beta$, y recluta la polimerasa al sitio de reparación (Figura 9). POL $\beta$ 
posee dos dominios que le confieren funciones diferentes: un dominio polimerasa y un pequeño dominio terminal $\mathrm{NH}_{2}$ que posee actividad AP liasa y que sustrae el residuo de azúcar-fosfato abásico. POL $\beta$ además interactúa con el complejo heterodímero de XRCC1-DNA ligasa III. XRCC1 actúa como proteína estabilizadora permitiendo la unión de la polimerasa y la ligasa al sitio de reparación. En ciertos casos en los que el residuo terminal de azúcar fosfato es estructuralmente mas complejo, se establece una ruta alternativa de reparación; la polimerasa POL $\delta$ actúa incorporando los nucleótidos faltantes. La nucleasa FEN1 remueve la región desplazada, evitando la formación de bucles durante la subsecuente síntesis de DNA y la proteína PCNA estimula estas reacciones estabilizando las diferentes proteínas al igual que XRCC1 lo hace en la ruta convencional. Otro factor de replicación, la DNA ligasaI (LIGI), finaliza entonces esta ruta alternativa de reparación (Fig. 9).

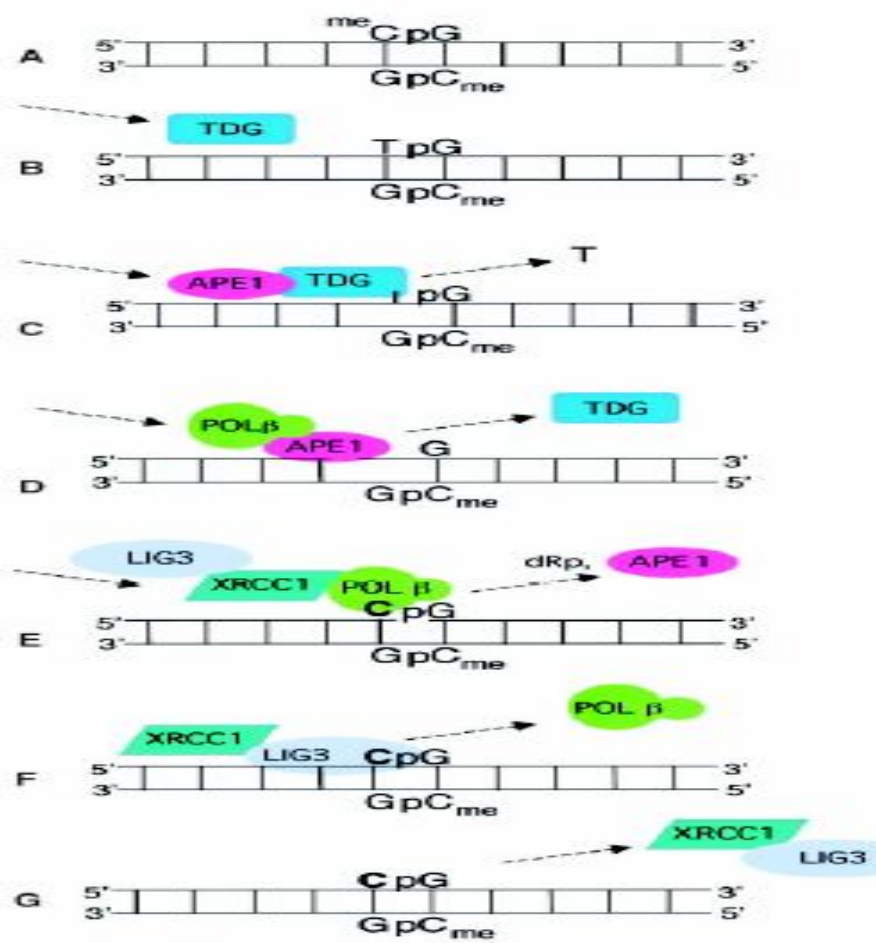

Figura 9. Mecanismo de reparación por escisión de bases (BER) ${ }^{199}$

III.- Las lesiones por ruptura de doble cadena (DBS) son probablemente las mas nocivas para la célula; surgen tras la acción de agentes exógenos como la radiación 
ionizante, ciertas drogas quimioterápicas, agentes endógenos como moléculas de oxigeno reactivas, y el estrés mecánico en los cromosomas. Estas lesiones son igualmente ocasionadas cuando las horquillas de replicación del DNA encuentran rupturas en una cadena o en el extremo terminal de los cromosomas debido a un metabolismo defectuoso de los telómeros. Una vez el daño en el DNA es detectado, el ciclo celular se detiene y se inicia la formación de complejos de ciertos factores de reparación, entre ellos la proteína quinasa ATM, que controla los reguladores del ciclo celular. Otros factores adicionales están representados por BRCA1 y BRCA2 que se encuentran mutados en el $15-20 \%$ de los cánceres de mama familiares y cuya función reside en la coordinación de la maquinaria de precombinación homóloga. Existe otro factor XRCC3 (de la familia de proteínas de RAD51) relacionado con polimorfismos asociados a un incremento en el riesgo de melanoma maligno y cáncer de vejiga ${ }^{200}$. Existen dos mecanismos de reparación de rupturas de doble cadena, nonhomologous end joining (NHEJ) y recombinación homologa (HRR), que incluyen mas de 20 genes que codifican las proteínas de RAD50-55, RAD57, y RAD59, MRE11, XRCC2, XRCC3 y XRS2, que reparan las rupturas de cadena producidas directamente por la exposición a radiación ionizante IR o indirectamente por reparación incompleta de otros daños.

Durante la precombinación homóloga pueden desarrollarse tres tipos diferentes de reparación:

- En la conversión génica los extremos de DNA son cortados en dirección 5'-3' por las nucleasas. Los extremos 3' de única cadena resultantes invaden la doble hélice de una molécula homologa y sin daño de DNA (localizado en una cromátida hermana, un cromosoma homólogo o en una posición ectópica) y copian las secuencias de esta por la acción de la DNA polimerasa. Esta interacción entre cadenas resulta en una conformación estructural particular (Holliday junctions) que permite, la separación final de las dos moléculas de DNA intactas (Figura 10 a). 
- Single strand annealing ocurre cuando secuencias repetitivas directas (de mínimo 30 pb) flanquean los dos extremos del DNA provocando la perdida de secuencia en el DNA por alineación de una sola cadena (Figura 10a).

- En algunas ocasiones solo un extremo de una lesión de doble cadena (DSB) es capaz de realizar precombinación homóloga, tal es el caso de los cromosomas haploides o hemicigotos de diploides G1 que no poseen un cromosoma homólogo. En estos casos se produce una replicación que induce ruptura (break-induced replication) (Figura 10c) en donde secuencias cercanas al lado proximal del centrómero del sitio de DSB son capaces de encontrar secuencias homólogas en algún otro lugar del genoma y crear una translocación no reciproca.

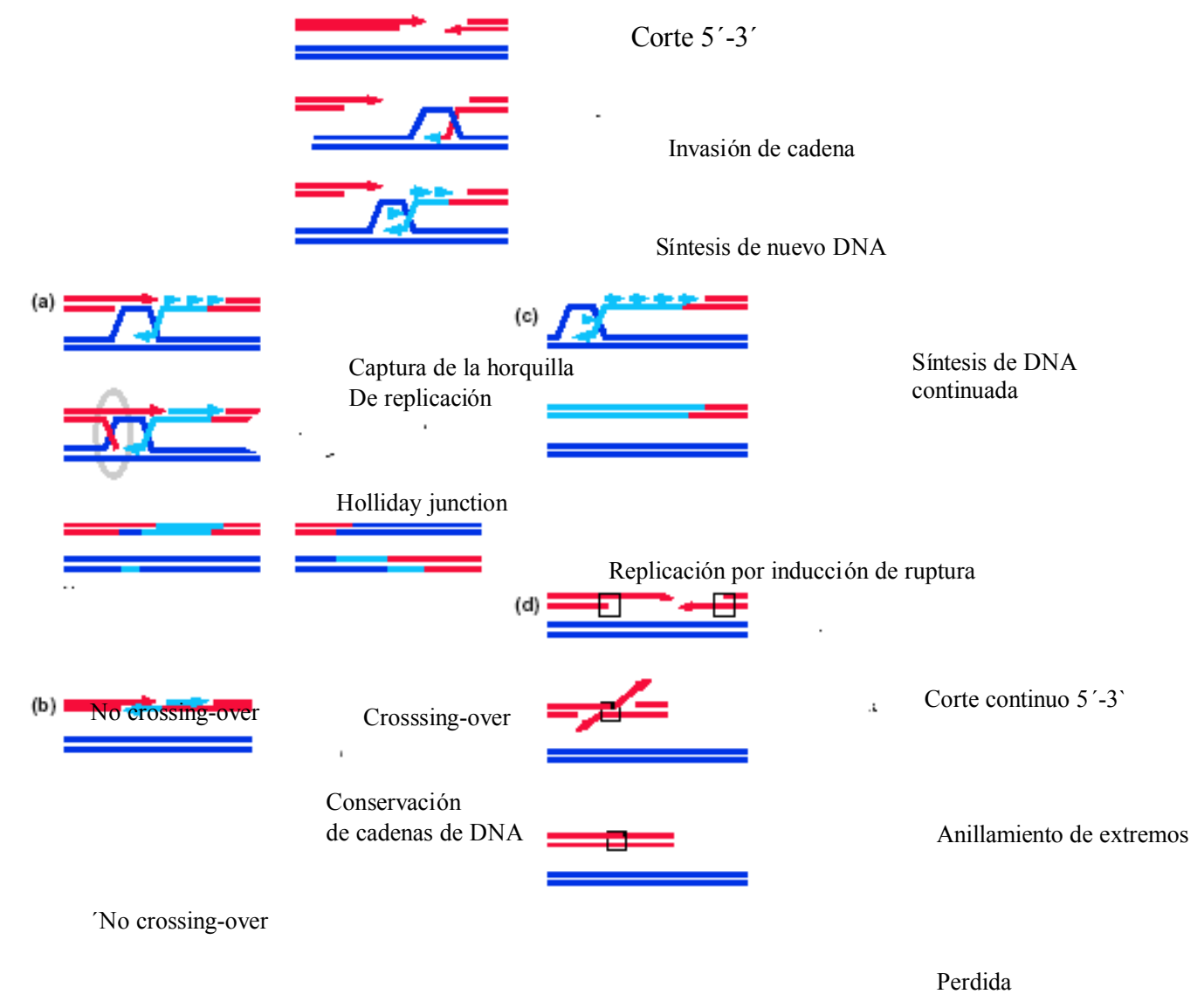

Figura 10. Mecanismos alternativos de reparación por recombinación homóloga de BSD ${ }^{201}$ 
La recombinación no homóloga (Non homologous end joining, NHEJ) por el contrario, no requiere homologías en los extremos terminales del DNA. Incluso en algunas ocasiones la unión de los dos extremos se produce simplemente tras una degradación limitada de las secuencias terminales ${ }^{202}$. Durante NHEJ el heterodímero de unión de extremos terminales de DNA de las proteínas Ku70 y Ku80 activa la subunidad catalítica (DNA-PKcs) de la proteína quinasa dependiente de DNA (DNAPK) estabilizando su unión con el DNA. Gracias a su conformación estructural DNAPK forma un anillo con tres aberturas que permite el paso de cadenas simples de DNA facilitando una alineación previa a la ligación. El proceso concluye tras la ligación de los extremos por acción de la DNA ligasa IV/Xrcc4 (Figura 11).

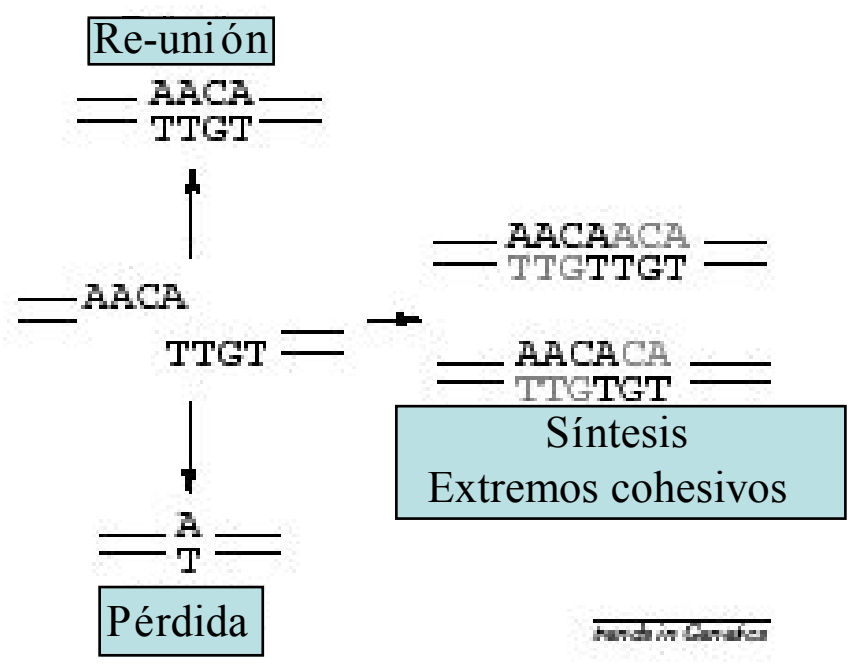

Figura 11. Mecanismos de recombinación no homóloga de BSD ${ }^{201}$

IV.- El mecanismo de reparación por escisión de nucleótidos (NER) incluye mas de 35 genes y remueve lesiones inducidas por UV y aductos de DNA asociados a exposiciones a químicos que distorsionan las hélices de DNA e interfieren en la unión normal de bases, pudiendo bloquear la replicación y trascripción normales. Existen dos mecanismos de reparación NER, uno general GG- NER que escanea el genoma entero y depende del complejo de reparación XPC-hHR23B, y otro sistema de reparación durante la trascripción TCR (transcription coupled repair) que reconoce daños que 
bloquean la actividad de la RNA polimerasa II en sitios transcripcionalmente activos. La tabla 9 muestra los factores implicados en NER, sus funciones, subunidades y sus respectivos homólogos en levadura y en murinos.

Tabla 9. Factores enzimáticos implicados en NER. Modificado de Hoeijmakers ${ }^{203}$

\begin{tabular}{|c|c|c|c|c|c|c|c|}
\hline Nombre & Función en NER & $\begin{array}{l}\text { Función } \\
\text { adicional }\end{array}$ & Nombre & $\begin{array}{c}\text { Tamaño } \\
\text { proteína(aa) }\end{array}$ & $\begin{array}{c}\text { Mutante } \\
\text { murino }\end{array}$ & $\begin{array}{l}\text { Homologo } \\
\text { S.cervisiae }\end{array}$ & Observaciones \\
\hline $\begin{array}{c}\text { XPC- } \\
\text { hHR23B }\end{array}$ & $\begin{array}{l}\text { Sensor de daño. } \\
\text { Factor de } \\
\text { reclutamiento de } \\
\text { reparación }\end{array}$ & $\begin{array}{l}\text { Solo en GG-NER. } \\
\text { No en TC-NER }\end{array}$ & $\begin{array}{c}\text { XPC } \\
\text { HHR23B } \\
\text { HHR23A }\end{array}$ & 940 & & $\begin{array}{l}\text { Rad4 } \\
\text { Rad23 } \\
\operatorname{Rad} 23\end{array}$ & $\begin{array}{l}\text { Afinidad por DNA } \\
\text { con daño } \\
\text { Estimula actividad } \\
\text { XPC in vitro } \\
\text { Puede sustituir } \\
\text { hHR23B in vitro }\end{array}$ \\
\hline TFIIH & $\begin{array}{l}\text { Cataliza formación } \\
\text { del complejo a } \\
\text { abertura sobre la } \\
\text { lesión. Facilita } \\
\text { ensamblaje } \\
\text { complejo de } \\
\text { reparación }\end{array}$ & $\begin{array}{l}\text { Trascripción basal } \\
\text { RNA Pol II. } \\
\text { Regulación ciclo } \\
\text { celular } \\
\text { Función adicional } \\
\text { NER-no } \\
\text { especifica en } \\
\text { TCR }\end{array}$ & $\begin{array}{c}\text { XPB } \\
\text { XPD } \\
\text { P34 } \\
\text { P44 } \\
\text { P62 } \\
\text { P52 } \\
\text { Mat1 } \\
\\
\text { Cdk7 } \\
\text { Ciclina H }\end{array}$ & $\begin{array}{l}782 \\
760 \\
303 \\
395 \\
548 \\
462 \\
309 \\
\\
346 \\
323\end{array}$ & $\begin{array}{l}\text { ERCC3 } \\
\text { ERCC2 }\end{array}$ & $\begin{array}{c}\text { Rad25/SSL2 } \\
\text { Rad3 } \\
\text { TFB4 } \\
\text { SSL1 } \\
\text { TFB1 } \\
\text { TFB2 } \\
\text { TFB3 } \\
\\
\text { Kin28 } \\
\text { CCL1 }\end{array}$ & $\begin{array}{c}3^{\prime} \text {-5'helicasa } \\
5^{\prime}-3 \text { 'helicasa } \\
\text { unión a DNA? } \\
\text { unión a DNA? } \\
\\
\text { Subcomplejo CAK } \\
\text { Subcomplejo CAK } \\
\text { Subcomplejo CAK }\end{array}$ \\
\hline XPA & $\begin{array}{l}\text { Se une a DNA } \\
\text { dañado. Facilita } \\
\text { ensamblaje } \\
\text { de complejo de } \\
\text { reparación }\end{array}$ & & XPA & 273 & & Rad14 & $\begin{array}{l}\text { Afinidad por DNA } \\
\text { lesionado de cadena } \\
\text { única }\end{array}$ \\
\hline RPA & $\begin{array}{c}\text { Estabiliza apertura } \\
\text { del complejo de } \\
\text { DNA. Localiza } \\
\text { nucleasas }\end{array}$ & $\begin{array}{l}\text { Replicación } \\
\text { recombinación }\end{array}$ & $\begin{array}{l}\text { RPA70 } \\
\text { RPA32 } \\
\text { RPA14 }\end{array}$ & $\begin{array}{l}616 \\
270 \\
121\end{array}$ & & $\begin{array}{l}\text { Rfa1 } \\
\text { Rfa2 } \\
\text { Rfa3 }\end{array}$ & $\begin{array}{l}\text { Unión ssDNA } \\
\text { Unión ssDNA }\end{array}$ \\
\hline XPG & $\begin{array}{c}\text { Cataliza incisión } 3^{\prime} \text {. } \\
\text { Estabiliza complejo } \\
\text { de apertura }\end{array}$ & $\begin{array}{c}\text { Actividad } \\
\text { adicional no-NER } \\
\text { especifica en } \\
\operatorname{TCR}(\dot{\zeta})\end{array}$ & XPG & 1186 & ERCC5 & $\operatorname{Rad} 2$ & $\begin{array}{l}\text { Miembro de familia } \\
\text { nucleasas de } \\
\text { estructura } \\
\text { específica FEN-1 }\end{array}$ \\
\hline $\begin{array}{c}\text { ERCC1- } \\
\text { XPF }\end{array}$ & Cataliza incisión 5 & $\begin{array}{l}\text { Reparación de } \\
\text { entrecruzamiento } \\
\text { entre cadenas. } \\
\text { recombinación vía } \\
\text { single-strand } \\
\text { annealing }\end{array}$ & ERCC1 & 297 & $\begin{array}{l}\text { ERCC1 } \\
\text { ERCC4 }\end{array}$ & Rad10 & $\begin{array}{l}\text { Endonucleasa de } \\
\text { estructura- } \\
\text { específica }\end{array}$ \\
\hline
\end{tabular}


En un primer paso de reconocimiento del daño en el DNA interviene la proteína XPC, al igual que XPA y un complejo de tres proteínas conocidas colectivamente como proteína de replicación A (RPA). XPC forma un complejo de iniciación junto con HHRAD23 e induce el reclutamiento y la posterior unión del resto de proteínas al DNA. Una tercera proteína denominada centrin2/caltracin1 presente en el centrómero de varios organismos ha sido recientemente identificada como estabilizadora del complejo XPC/HHRAD23 ${ }^{203}$. El ensamblaje de la maquinaria de reparación restante, incluye el factor de trascripción TFIIH constituido por 6 subunidades que facilitan parcialmente la apertura de las cadenas de DNA. Dos de sus subunidades, XPB y XPD, poseen actividad ATPasa y helicasa dependiente de DNA. XPB desenvuelve el DNA en dirección 3'-5'y XPD lo hace en la dirección contraria. Las endonucleasas (XPG, ERCC1-XPG) cortan las uniones aberrantes en las cadenas de DNA a una distancia aproximada de 30 nucleótidos y según la polaridad; XPG tiene el sitio de corte 3', mientras que él heterodimero ERCC1-XPF lo hace en el sitio 5'. El fragmento es sustituido entonces por las DNA polimerasas $\delta$ o $\varepsilon$ y las proteínas de repara ración PCNA, RPA y RFC. RF-C se une preferiblemente al extremo 3' del primer de DNA y facilita la unión de PCNA que forma una estructura anillada y homotrimérica que puede

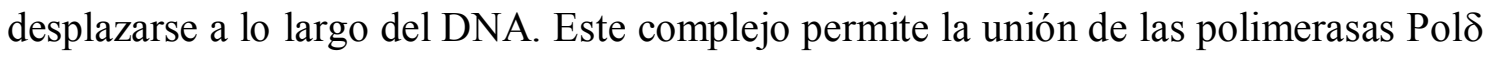
y Pole que, formando holoenzimas con los cofactores, pueden replicar los fragmentos de una sola cadena de DNA. Finalmente la DNA ligasa I se encarga de la unión del extremo 5' del nuevo fragmento sintetizado con la secuencia original (Figura 12). 

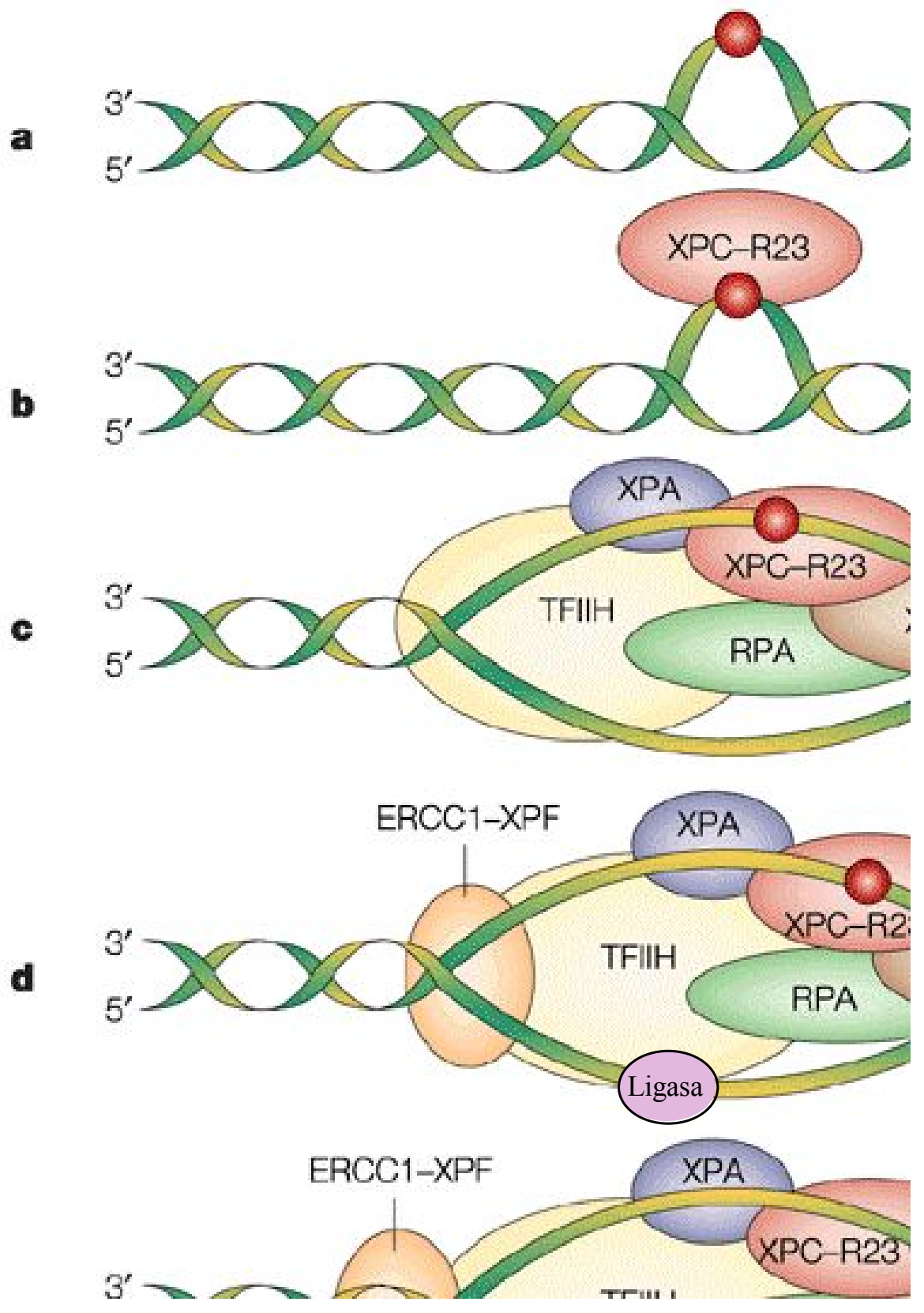

Figura 12. Mecanismo general de reparación por escisión de nucleótidos NER. ${ }^{204}$

El mecanismo de reparación de las regiones transcripcionalmente activas (TCR) no ha sido bien descrito hasta el momento, sin embargo es claro que el reconocimiento del daño esta caracterizado por una detención en el complejo transcripcional de la RNA 
polimerasa II y el reclutamiento de ciertas proteínas como CSA y CSB. Igualmente interactúan los complejos de helicasas de TFIIH y XPG ${ }^{205}$. Mutaciones que inactivan los genes que codifican estas dos proteínas (CSA y CSB) producen una enfermedad hereditaria conocida como el síndrome Cockayne caracterizada por una alta fotosensibilidad (Figura 13) ${ }^{206}$.

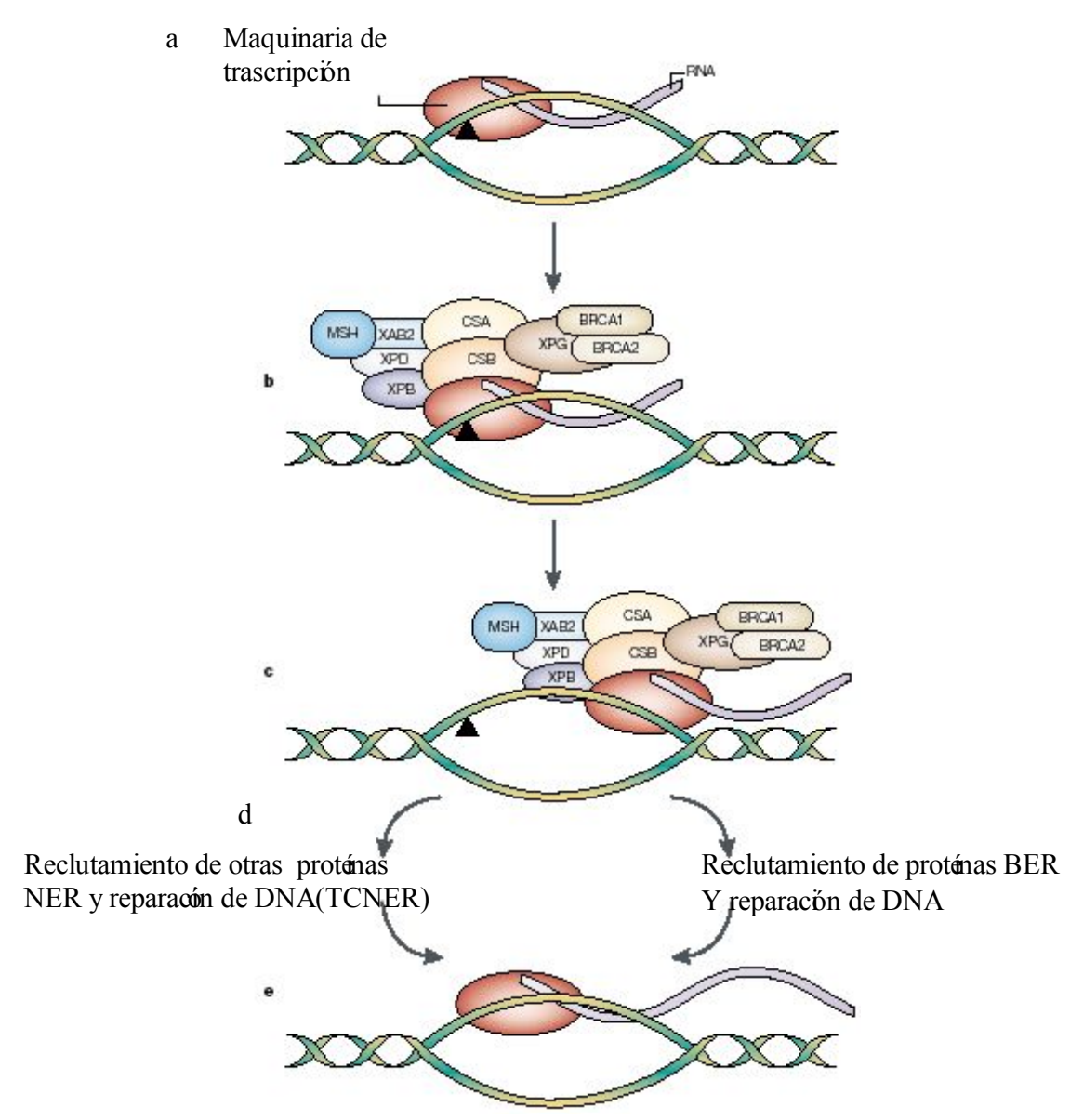

Figura 13. Mecanismo de reparación de las regiones activas transcripcionalmente (TCR) en NER ${ }^{204}$.

Defectos en el mecanismo de reparación NER suponen fotosensibilidad extrema y predisposición al cáncer de piel observado en el fenotipo prototipo de un síndrome de reparación como es Xeroderma pigmentosum (XP). 


\section{4.- Polimorfismos del DNA.}

Menos del 10\% del total del genoma humano engloba al DNA "funcional", constituido por genes y regiones implicadas en la regulación transcripcional, así como en mantener la estructura e integridad cromosómica ${ }^{207}$.

Alrededor del 15\% del genoma humano es moderada a altamente repetitivo, dividiéndose en función de cómo se agrupen las unidades de repetición, en "DNA repetitivo" cuando las unidades de repetición individuales están dispersas aisladamente, o en "DNA satélite" cuando las unidades están reunidas en grupos.

Un locus polimorfo se define como aquél cuyos alelos o variantes son tales que la variante más común entre ellos ocurre con menos del 99\% de frecuencia en la población total. Entre los polimorfismos se incluyen los SNP (single nucleotide polymorphism) y los STR (short tandem repeat) los cuales nos permiten realizar estudios en los que se intenta asociar con determinados fenotipos.

Polimorfismo de nucleótido único (SNP): Es la forma más simple de polimorfismo y se origina como resultado de la mutación de una sola base. Inicialmente se denominó polimorfismo de longitud de fragmentos de restricción debido a que su estudio se realizo utilizando enzimas de restricción que localizaban puntos concretos donde el cambio de una sola base producía variantes en los tamaños de los fragmentos generados. $^{208}$.

Los SNPs constituyen la variación genética humana más importante, produciéndose con una densidad promedio de 1/1000 nucleótidos de un genotipo, pudiendo encontrarse con un promedio de cada 0.3-1 kilobase (kb) en el genoma ${ }^{209}$.

Aquellos SNPs que se originan en regiones codificantes, al producir variantes aminoácidas, afectan con mayor probabilidad al fenotipo, estimándose que aproximadamente el 20\% de los SNPs humanos originan una proteína variante. E1 genotipo humano es portador de aproximadamente 103 de estos SNPs que juntos causan una importante variación del fenotipo. ${ }^{210}$. 
$\underline{\text { Repeticiones en tandem de número variable (variable number of tandem repeats, }}$ VNTR) o sencillas ( simple tandem repeats, STR): También denominados minisatélites y microsatélites. Se producen como resultado de una inserción o deleción de una sección del DNA. Los VNTR presentan patrones de repetición de varios cientos de pares de bases (bp) y los STR de 2-4 bp con una frecuencia de cada 3-10 kb.

Polimorfismos de grandes inserciones/deleciones ${ }^{137}$ : Se producen con un promedio de $3 \mathrm{~kb}$. Los segmentos resultantes de este polimorfismo presentan dos secuencias de 120-150 bp de longitud, separadas por un segmento rico en adeninas, produciendo grandes diferencias en los fragmentos resultantes de la amplificación.

Los polimorfismos bialélicos, que se originan habitualmente de un SNP originan tres genotipos diferentes: El homocigoto de alelo común, el heterocigoto, y el homocigoto de alelo raro. Por el contrario, los STR producen muchos genotipos, los cuales se agrupan para simplificar el análisis. La alta tasa de mutaciones en los STR seguramente lleva a asociaciones más débiles a menos que el polimorfismo se localice en una región codificante.

Tabla 10. Clasificación del DNA repetitivo ${ }^{207}$.

\begin{tabular}{||c|c|c|c|c||}
\hline \hline Satélite & $\begin{array}{c}\text { Minisatélite } \\
\text { (telomérico) }\end{array}$ & $\begin{array}{c}\text { Minisatélite } \\
\text { (hipervariable) }\end{array}$ & Microsatélites \\
\hline \hline nombre & --- & -- & VNTRs & STRs \\
\hline Tamaño & $500-1000 \mathrm{bp}$ & ttaggg (humanos) & $6-50 \mathrm{bp}$ & $1-5 \mathrm{bp}$ \\
\hline $\begin{array}{c}\text { Expansión } \\
\text { total }\end{array}$ & $100-10.000 \mathrm{~kb}$ & $10-15 \mathrm{~kb}$ & $100 \mathrm{bp}-20 \mathrm{~kb}$ & $10-100 \mathrm{bp}$ \\
\hline $\begin{array}{c}\text { Localización } \\
\text { a centromérica }\end{array}$ & $\begin{array}{c}\text { Tetelómeros } \\
\text { telos }\end{array}$ & $\begin{array}{c}\text { La mayoría en regiones } \\
\text { teloméricas }\end{array}$ & Ubicuitamente \\
\hline Función & $\begin{array}{c}\text { Probablemente } \\
\text { ninguna }\end{array}$ & $\begin{array}{c}\text { Protege el final del } \\
\text { cromosoma }\end{array}$ & $\begin{array}{c}\text { Raros ejemplos de } \\
\text { expresión desconocida }\end{array}$ & $\begin{array}{c}\text { Tono fino de la } \\
\text { expresión génica }\end{array}$ \\
\hline
\end{tabular}

Estudio de los polimorfismos de genes reparadores en población fumadora con y sin cáncer de pulmón 


\section{1.- Significado biológico.}

El estudio de polimorfísmos permite definir, en el caso del cáncer, perfiles genómicos asociados con la susceptibilidad a desarrollar ciertos tumores. No sólo eso, sino que permitirá predecir la respuesta a los fármacos facilitando el acceso a un tratamiento cada vez más individualizado. También sirven, en el caso de los microsatélites, como marcadores genéticos para identificar genes relacionados a enfermedad por estudios de asociación familiar, si bien la información será menor que la proporcionada por los polimorfismos multialélicos de longitud de secuencia sencilla, al tener únicamente dos alelos, problema que puede ser compensado por la mejor automatización de los SNPs debido a una mayor densidad de estos. El mapeo de extensas colecciones de SNPs podría servirnos para realizar estudios genéticos a gran escala en humanos.

\section{2.- Polimorfismos del gen TP53.}

En el gen TP53 se han descrito varios polimorfismos; entre los más frecuentes podemos citar:

- Intrón 1. Se ha descrito un polimorfismo que crea un sitio Bgl-II (5'-A*GATCT-3*). Como consecuencia del cambio de un residuo adenina en la posición 8.545 por una timidina, complementándose con la presencia, en algunos alelos, de una timidina en lugar de la habitual citosina en la posición $8550^{211}$.

- Intrón 3. Se ha encontrado una inserción e 16 bp en el nucleótido 11.951 de la secuencia de la TP53 (figura 14), correspondiente a la repetición exacta de 16 bp. La secuencia repetida se encuentra entre dos motivos idénticos de 8 bp (5'GGGCTGGG -3') también encontrado al final de la repetición de 16 bp y puede ser el responsable de la generación de la repetición por error de apareamiento durante la síntesis de DNA. En realidad son secuencias alternas repetidas. 
$\mathrm{nt} 11.943$

nt11.990

gggctggg+gacctgga-gggctggg+gacctgga-gggctggg-gggctggg-gggctga-gacctgg inserción

Figura 14. Polimorfismo bialélico en el intrón 3.

- Exón 4 (codón 47). Este infrecuente polimorfismo reemplaza a la Prolina (CCG) con una Serina (TCG) en el codón 47 del exón 4 de TP53, perdiéndose el lugar de corte de Nci-1 ( $\left.5^{\prime}-\mathrm{CC}^{*} \mathrm{C} / \mathrm{GGG}-3^{\prime}\right)$. Debido a su rareza, no se han determinado aún sus consecuencias sobre el fenotipo ${ }^{212}$.

- Exón 4 (codón 72). En 1987, Matlashewski y cols, observan que algunas células humanas transformadas (SV-80, Raji y líneas celulares linfoblastoides) contenían dos proteínas p53 distintas, y que las diferentes formas no eran debidas a glicosilación o variación en la cantidad de fosforilación del polipéptido ${ }^{213}$. La secuenciación del cDNA del gen p53 ${ }^{214}$ mostró una diferencia de una sola base entre estos clones que resultaba de un cambio no conservador, un residuo Arginina en p53 de fibroblastos humanos normales reemplazado por un residuo Prolina en p53 de fibroblastos humanos transformados por SV-40 (SV-80). La G en el nucleótido 347 genera un codón que codifica Arginina (CGC) en el residuo aminoácido 72. La C en el nucleótido 347 da lugar a un codón que codifica Prolina (CCC) en el residuo aminoácido 72 (pérdida de un sitio BstU-1: 5'-CG*CG-3).

- Intrón 6. Se ha encontrado una substitución de una base en el intrón 6 producida por la substitución de un residuo de guanina en la posición 13.494 (a 61 bp 3'del exón 6) por una adenina ${ }^{215}$, originando la perdida de un sitio de restricción Msp-1 (5'C*(GG-3').

- Intrón 6. Se ha identificado una transversión de G a C en la base 13.964 en mujeres con cáncer de mama y ovario, relacionándolo en un principio con un polimorfismo de significado no claro. Actualmente se ha asociado dicha mutación a actividad funcional en cáncer de mama no asociado a genes de susceptibilidad (BRCA1/2) en el 
$7.1 \%$ versus $0 \%$ en cáncer de mama esporádico ${ }^{216}$. El alelo común contiene un sitio Cfo-l que es destruido por la mutación.

Tabla 11. Polimorfismos caracterizados en regiones intrónicas del gen TP53.

\begin{tabular}{|c|c|c|c|c||}
\hline & $\underline{\text { Nucleótido }}$ & $\underline{\text { Tipo }}$ & $\underline{\text { Cambio }}$ & $\underline{\text { Autor }}$ \\
\hline \hline Intrón 1 & 8545 & Puntual & $\mathrm{T}>\mathrm{A}$ & Willems (1992) \\
\hline Intrón 1 & 8703 & Inserción & (AAAAT)n & Futreal (1991) \\
\hline Intrón 1 & & & Hae III RFLP & Ito (1994) \\
\hline Intrón 2 & $38 \mathrm{pb} 3$ ' exón 2 & Puntual & $\mathrm{G}>\mathrm{C}$ & Pleasants (1994) \\
\hline Intrón 3 & 11951 & Inserción & $+16 \mathrm{pb}$ & Lazar (1993) \\
\hline Intrón 6 & $61 \mathrm{pb} 3{ }^{\prime}$ exón 6 & Puntual & $\mathrm{A}>\mathrm{G}$ & Chumakov (1991) \\
\hline Intrón 7 & $20 \mathrm{pb} 3$ ' exón 7 & Puntual & $\mathrm{T}>\mathrm{G}$ & Prosser (1991) \\
\hline Intrón 9 & $12 \mathrm{pb} 3$ ' exón 9 & Puntual & $\mathrm{T}>\mathrm{C}$ & Graziani (1999) \\
\hline
\end{tabular}

Tabla 12. Polimorfismos caracterizados en regiones codificantes del gen TP53.

\begin{tabular}{|c|c|c|c|c|c|c|c||}
\hline & Codon & Tipo & Inicio & Final & Cambio & Frecuencia & Autor \\
\hline \hline Exón 2 & 21 & Puntual & GAC & GAT & Silente & $?$ & Ahuja (1990) \\
\hline Exón 4 & 36 & Puntual & CCG & CCA & Silente & $4 \%$ & Felix (1994) \\
\hline Exón 4 & 47 & Puntual & CCG & TCG & Pro>Ser & $>1 \%$ & $\begin{array}{c}\text { Felley-Bosco } \\
(1993)\end{array}$ \\
\hline Exón 4 & 72 & Puntual & CGC & CCC & Arg>Pro & Amplio & $\begin{array}{c}\text { Matlashewski } \\
(1987)\end{array}$ \\
\hline Exón 6 & 213 & Puntual & CGA & CGG & Silente & $11 \%$ & Carbone (1994) \\
\hline
\end{tabular}




\subsection{1.- Relación del polimorfismo en el codon 72 de p53 con el cáncer de pulmón.}

El tabaquismo es un factor de riesgo fundamental para el cáncer de pulmón. No obstante, dado que solo una pequeña proporción de los fumadores desarrollan la enfermedad, otros factores, incluida la susceptibilidad genética, deben ser importantes en la determinación del riesgo del cáncer de pulmón ${ }^{50}$.

El codón 72 del exón 4 codifica dos tipos de alelos, arginina (CGC) o prolina (CCC). Este polimorfismo se ha asociado con una mayor susceptibilidad para desarrollar cáncer de pulmón. Sin embargo, no todos los estudios han sido consistentes, y esta hipotética asociación continua siendo controvertida ${ }^{194,217}$.

La mayoría de los estudios epidemiológicos han sido de casos-controles, mostrando un incremento del riesgo de padecer cáncer de pulmón tanto para el genótipo homocigoto prolina ${ }^{194,218-224}$ como para el genotipo heterocigoto arginina/prolina ${ }^{194}$, ${ }^{222}$, y un efecto protector del genotipo homocigoto Arginina ${ }^{225}$. Igualmente se han publicado estudios en los que no se ha demostrado un incremento del riesgo de desarrollar cáncer de pulmón con dichas variantes genotípicas ${ }^{50,219,226-229}$.

Algunos estudios indican que el polimorfismo en el codon 72 incrementa el riesgo de desarrollar determinados subtipos histológicos del carcinoma no microcítico de pulmón, especialmente la variedad adenocarcinoma ${ }^{194,221}$.

Este polimorfismo se ha visto asociado a una mayor respuesta al tratamiento quimioterápico con platinos en paciente con carcinoma no microcítico de pulmón. 


\subsection{3.- Relación del polimorfismo en el intrón 3 de p53 con el cáncer de pulmón.}

Este polimorfismo consiste en la repetición única de 16 nucleótidos en el intrón 3 de p53. Fue descrito por primera vez en 1993 en la población caucásica, observándose un $28 \%$ de heterocigosidad en los 82 pacientes estudiados ${ }^{230}$.

Dos estudios han examinado la asociación entre el polimorfismo en el intrón 3 y el riesgo de cáncer de pulmón. En uno de ellos no se detecto una asociación significativa entre este polimorfismo y el riesgo de cáncer de pulmón ${ }^{229}$; OR 1.24 (95\% CI $0.37 \pm 4.20)$ para la variante alela homocigota y $0.74(95 \%$ CI $0.46 \pm 1.18)$ para los potadores. En otro estudio se observo un incremento del riesgo de cáncer de pulmón para los homocigotos (OR ajustada $2.37,95 \%$ CI $0.76 \pm 7.39$ ) y para los portadores de los genotipos con el alelo variante $(1.77,95 \%$ CI $1.24 \pm 2.52)$ en la raza caucásica y hispano-americanos. Esta asociación no se observo en la raza afroamericana ${ }^{231}$. La OR común para la variante alela homocigota y los genotipos portadores fue 1.50 (95\% CI $0.76 \pm 2.97)$ y $1.11(95 \%$ CI $0.53 \pm 2.35)$ respectivamente. Un posterior meta-análisis publicado en 2003 combinando estos estudios mostró una OR de cáncer de pulmón de 1.50 (95\% CI 0.76-2.97) y 1.11 (95\% CI 0.53-2.35) para el genotipo homocigótico y la variante alélica $^{232}$.

\section{3.- Polimorfismos en los genes reparadores de tumores XRCC1 y ERCC1 y relación con el cáncer de pulmón.}

El humo del tabaco contiene miles de sustancias químicas que modifican químicamente el DNA ${ }^{82}$ y permiten el desarrollo de mutaciones. La capacidad para reparar el DNA dañado por los carcinógenos activados parece ser uno de los principales factores que pueden influenciar en el cáncer de pulmón, y una menor capacidad para reparadora se ha asociado con un mayor riesgo de cáncer de pulmón ${ }^{233-237}$. Estos estudios sugieren que una menor capacidad de actuación en varios mecanismos de 
reparación del DNA predisponen individualmente al cáncer de pulmón. Se han identificado un gran número de polimorfismos (SNPs) en genes de reparación de DNA 195, 238 . Los polimorfismos en los genes de reparación del DNA se pueden asociar con diferencias en la reparación del DNA dañado, pudiendo influir en el riesgo individual de cáncer de pulmón debido a que la variante genotípica en ese polimorfismo puede destruir o alterar la función reparadora.

ERCC1 y XRCC1 juegan un importante papel en el proceso de reparación de escisión de nucleótidos. El hecho de que polimorfismos en estos genes reparadores disminuyen la capacidad para la reparación del daño causado al DNA por el tabaco queda reflejado en trabajos que demuestran que polimorfismos en ERCC1 y en XRCC1 pueden modificar el riesgo de cáncer de pulmón en función del numero de paquetes/año fumados ${ }^{239-242}$.

El gen XRCC1 expresa una proteína involucrada en la adecuada reparación de los puentes de unión en el DNA producidos por la exposición a radiaciones ionizantes y agentes alquilantes. Esta proteína interactúa con la DNA ligasa III, DNA polimerasa beta, APE, polinucleótido kinasa y poil(ADP-ribosa) polimerasa, participando en la vía de reparación por escisión de bases. Puede jugar un papel en el procesamiento del DNA en las células germinales. E1 gen de XRCC1 se localiza en el cromosoma19q13.2. Está formado por 17 exones y codifica una proteína de 633 aminoácidos. Los polimorfismos de nucleótido único (SNP) más ampliamente estudiado son Arg280His localizado en el exón 9, Arg399Gln localizado en el exón 10 y Arg194Trp localizado en el exón 6 y que es el polimorfismo estudiado en nuestro trabajo doctoral.

Se han encontrado asociaciones entre polimorfismos en XRCC1 y mutaciones en el gen p53 que pudieran explicar el papel de XRCC1 en el daño al DNA inducido por el tabaco en pacientes con cáncer de pulmón ${ }^{243}$.

La región codificante de ERCC1 tiene una longitud de $1.1 \mathrm{~kb}$ y comprende 10 exones. Este gen se localiza en 19q13.2-q13.3. Se han identificado polimorfismos en 3 
de los exones de ERCC1, todos los cuales resultan en mutaciones silentes ${ }^{195}$, no observándose sustituciones de aminoácidos entre los polimorfismos de ERCC1 ${ }^{244}$.

Desde hace ya más de una década es bien sabido que el mecanismo de reparación por escisión de nucleótidos está involucrado en la resistencia a la quimioterapia en ciertos tipos de tumores, incluyendo las sales de platino. En 2006, Olaussen et al. publicaron que la ausencia de evidencia inmunohistoquímica de la proteína ERCC1 en los tumores se asociaba a un beneficio en la supervivencia en los carcinomas no microcíticos de pulmón tratados con quimioterapia basada en cisplatino ${ }^{141}$. ERCC1 es una proteína altamente conservada esencial para la vida. Si bien es solo una de las múltiples proteínas implicadas en la reparación por escisión de nucleótidos, juega un papel limitante de función. Forma un complejo con otra proteína, XPF, y el heterodímero realiza el último de los pasos iniciales en la vía de reparación por escisión de nucleótidos - la escisión del extremo 5' de la hebra de DNA en el lugar del DNA dañado. La expresión de ERCC1 está influenciada por complejos factores, incluyendo polimorfismos y uniones alternativas. 


\section{2.- HIPOTESIS Y OBJETIVOS}




\section{1. - H I P O T E S I S}

El cáncer de pulmón representa uno de los problemas de salud más importantes, ya que es la causa de muerte de la mayoría de los enfermos que lo desarrollan, y la supervivencia a los 5 años continua siendo menor del 10\%. Encabeza la lista de los tumores más frecuentes en el varón y la tendencia en las mujeres es a igualarse con la de los hombres, habiendo superado al cáncer de mama en algunos países desarrollados. Así pues, nos encontramos ante el cáncer más importante, tanto en términos de incidencia como en lo que respecta a agresividad y letalidad. El tabaquismo es una causa fundamental del cáncer de pulmón. No obstante, dado que solo una pequeña proporción de los fumadores desarrollan la enfermedad, otros factores, incluida la susceptibilidad genética, deben ser importantes en la determinación del riesgo del cáncer de pulmón ${ }^{50}$.

El gen supresor de tumores p53 se encuentra mutado en muchos tipos de carcinomas humanos. Además se ha descrito un polimorfismo en el codón 72 del exón 4, que codifica dos tipos de alelos, o arginina o prolina ${ }^{245}$. Este polimorfismo se ha asociado con una mayor susceptibilidad para desarrollar cáncer. Sin embargo, no todos los estudios han sido consistentes, y esta hipotética asociación continua siendo controvertida $^{194,217}$. Igualmente se han descrito polimorfismos en el intrón 3 de p53 que pueden predisponer a una mayor susceptibilidad para desarrollar cáncer ${ }^{232}$.

El humo del tabaco induce daño al DNA y una menor capacidad para reparar el DNA se ha asociado con un mayor riesgo de cáncer de pulmón. ERCC1 y XRCC1 juegan un importante papel en el proceso de reparación de excisión de nucleotidos. Una baja expresión de mRNA de ERCC1 y XRCC1 se ha asociado con un mayor riesgo para padecer cáncer. Para comprobar la hipótesis de que la diferente capacidad de reparación 
del DNA determinada por alteraciones genéticas puede variar la susceptibilidad al riesgo de padecer cáncer de pulmón, se han realizado múltiples estudios epidemiológicos caso-control. 


\section{2 . - O B J E T I V O S}

\section{1.- Objetivo principal}

En este trabajo pretendemos determinar si existe un mayor riesgo de desarrollar cáncer de pulmón en función de las diferentes variantes del polimorfismo del codón 72 del gen TP53, el Intrón 3 de TP53, A19886G(Thr75) de XRCC1 y Arg194Trp de ERCC1.

\section{2.- Objetivos secundarios}

1) Describir las características clínicas de la muestra.

2) Determinar la influencia de los factores de riesgo en el desarrollo de cáncer de pulmón

3) Comparar la distribución de variables genéticas y no genéticas entre casos y controles.

4) Estudiar la relación entre las frecuencias alélicas y las frecuencias genotípicas de los diferentes grupos (equilibrio de Hardy y Weinberg).

5) Análisis de las distribuciones alélicas (frecuencias).

6) Análisis de la asociación entre la enfermedad y todos los polimorfismos a la vez. 


\section{3.- MATERIAL Y MÉTODOS}




\section{1.- CONTROLES.}

Se han analizado 306 muestras de sangre periférica. De ellas, 151 han sido obtenidas de varones mayores de 65 años de edad y fumadores de más de 20 cigarrillos/día durante al menos 20 años, que no han padecido ningún tipo de cáncer a lo largo de su vida. Las otras 155 han sido obtenidas de personas fumadoras menores de 65 años de edad, que tampoco han padecido ningún tipo de cáncer a lo largo de su vida.

\section{2.- PACIENTES.}

Se han estudiado los genotipos de un total de 164 muestras de sangre periférica de pacientes con Cáncer de pulmón.

Se mantuvo la confidencialidad de los datos personales y géneticos respetando en todo momento los principios éticos básicos de la investigacion con muestras biológicas y lo establecido por la legislación aplicable (Ley Organica 15/1999 de 13 de diciembre, de Protección de Datos, Ley 41/2002 de Autonomia del Paciente y Sanitaria y Ley 14/1986, General de Sanidad).

Se cumplieron los principios éticos de investigación recogidos en la declaración de Helsinki y en el informe Belmont asi como los contenidos en la Declaración Universal de la Unesco referentes al genoma humano. De igual manera se dio cumplimiento a la Ley Orgánica para la Regulación del Tratamiento Automatizado de Datos de Personal. El presente proyecto de investigación contó con la aprobación por parte del Comité de Investigación del Hospital Clínico de Salamanca, asi como de la comisión de Etica del mismo.

\section{3.- EXTRACCION Y PURIFICACION DEL DNA.}

\section{1.- Sangre periférica.}

Obtención de células nucleadas: El estudio se llevó a cabo a partir de muestras de 
sangre periférica obtenidas por venopunción. Las muestras se conservaron a $4{ }^{\circ} \mathrm{C}$ hasta su procesamiento. Las células nucleadas de la sangre se aislaron mediante centrifugación repetida y lisis eritrocitaria con solución hipotónica (centrifugación de la sangre total en ddH2O durante 30 minutos, a $580 \mathrm{~g}$, a temperatura ambiente). Tras la recuperación de la interfase creada y lisis de los hematíes contaminantes con agua destilada, se lavaron las células mononucleadas en tampón Fornace y se precipitaron mediante centrifugación a 580 g durante 20 minutos. El botón celular así obtenido se utilizó para la extracción del DNA de manera idéntica a lo descrito para el tumor.

\subsection{Aislamiento del DNA de alto peso molecular.}

El botón de células nucleadas de la sangre se resuspendieron en tampón Fornace (0.25M Sacarosa; 50mM Tris-HCl pH7.5; $25 \mathrm{mM} \mathrm{KCl;} 5 \mathrm{mM} \mathrm{MgCl2}$ ) a una concentración estimada de 5x106 células/ml., tras lo cuál se añadió EDTA (ácido etilendiamino-tetraacético, concentración final $10 \mathrm{mM}$ ), SDS (Sodium Dodecyl Sulfate, concentración final 1\%) y Proteinasa K (Boehringer Mannheim, concentración final 50 $\mu \mathrm{g} / \mathrm{ml}$.). La mezcla se incubó a $55^{\circ} \mathrm{C}$ durante 8 - 16 horas. Tras la incubación, la solución que contiene el DNA se mezcló con medio volumen de fenol redestilado (Appligene, U.S.A.) y medio volumen de la mezcla Cloroformo/Alcohol isoamílico (CIAA 24:1 v/v). Tras una centrifugación a $580 \mathrm{~g}$ durante 10 minutos a temperatura ambiente, se recuperó la fase acuosa sobrenadante conteniendo el DNA en solución, y se añadió un volumen igual de CIAA con el fin de retirar restos proteicos y fenol y, tras mezclarlos hasta su homogeneización, se sometió a una nueva centrifugación en condiciones idénticas, recuperando nuevamente la fase acuosa. Posteriormente, la fase acuosa se transfirió a tubos Corex ${ }^{\circledR}$ estériles y el DNA de ésta solución final se precipitó mediante la adición de 2.5 volúmenes de etanol absoluto frío $\left(-20^{\circ} \mathrm{C}\right)$. El DNA se transfirió a un eppendorf, se lavó con etanol al 70\% con una breve centrifugación a 16,000 rpm, y se dejó evaporar el etanol residual, para disolver finalmente el DNA en $100 \mu 1$ de agua bidestilada (ddH2O) estéril.

La concentración y el grado de contaminación proteica del DNA así obtenido se 
calculó tras medir su absorbancia a 260 y $280 \mathrm{~nm}$ respectivamente, en un espectrofotómetro (GeneQuant, Pharmacia) por medio de la siguiente fórmula:

$$
\mu g \text { de DNA/ml }=\left(D . O{ }_{260}\right) \times(\text { factor de dilución }) \times(50)
$$

(Nota: 50 es un factor de corrección introducido ya que una unidad de densidad óptica con una luz incidente de $260 \mathrm{~nm}$ es el valor de absorbancia que tienen $50 \mu \mathrm{g}$ de DNA/ml).

El cociente D.O. ${ }_{260}$ /D.O. ${ }_{280}$ se utiliza para determinar el grado de contaminación proteica, considerando como valores adecuados un cociente entre 1.65 y 2.0. Valores inferiores a los señalados indican contaminación por proteínas o por solventes orgánicos, realizándose en éstos casos una nueva purificación del DNA. Valores superiores parecen indicar un exceso de RNA, el cuál se eliminó tratando la solución de DNA con RNAsa y purificando nuevamente según el método antes descrito.

La muestra de DNA con una concentración aproximada entre 1,000 y 1,500 $\mu \mathrm{g} / \mathrm{ml}$, , se almacenó en tubos eppendorf a $-20{ }^{\circ} \mathrm{C}$, con el fin de evitar tanto la degradación progresiva del DNA como su posible contaminación por microorganismos.

\section{4.- ESTUDIO DEL POLIMORFISMO DEL CODON 72 DEL GEN P53.}

Las endonucleasas de restricción reconocen secuencias específicas de DNA y lo escinden en ese punto. Las digestiones con enzimas de restricción se llevaron a cabo incubando el producto de PCR con $1 \mu \mathrm{l}$ de la endonucleasa de restricción BST U1 a la temperatura adecuada para la actividad de esa enzima en particular, utilizando como tampón de digestión el específico para cada endonucleasa o un tampón preparado en nuestro laboratorio (Tris 100 mM pH 7,5; $\mathrm{NaCl} 50$ mM; MgCl2 10 mM; espermidina 10 $\mathrm{mM} ; \beta$-mercapto-etanol $1 \mathrm{mM}$ ).

Para excluir contaminación cruzada, todos los experimentos fueron realizados en ambientes especialmente diseñados para PCR y siempre incluyendo controles negativos. 
Los fragmentos obtenidos tras la digestión del DNA fueron separados mediante electroforesis en geles de agarosa. En todos los geles se incluyó un marcador de tamaño. Para monitorizar la migración del DNA en el gel, se incluyeron dos colorantes en el tampón de carga: azul de bromofenol y xileno-cianol.

Tras la electroforesis, el DNA se visualizó tiñiendo el gel con bromuro de etidio $(0,5 \mu \mathrm{g} / \mathrm{ml})$ y se realizó una foto con una cámara digital Kodak DC-40 bajo iluminación ultravioleta, usando el programa Kodak Digital Science ID.

- Amplificación del codón 72 de TP53:

- Condiciones (protocolo de amplificación)

- $\left(94^{\circ} \mathrm{C} 30 \mathrm{~s}, 62^{\circ} \mathrm{C} 1 \mathrm{~min}, 70^{\circ} \mathrm{C} 1 \mathrm{~min}\right) \mathrm{X} 30,70^{\circ} \mathrm{C} 10 \mathrm{~min}$.

- Secuencias de oligonucleótidos

- Oligonucleótido de sentido:

5'-TGC CGT TCC CCC TGA CAT CT-3'

- Oligonucleótido anti-sentido:

Se realizó mediante amplificación por PCR del codón 72 y subsecuente digestión de los productos de PCR con BstU-I. Cien nanogramos de DNA fueron amplificados en un volumen de $50 \mu \mathrm{l}$ con el compuesto PCR Supermix, $1.5 \mathrm{mM}$ de $\mathrm{MgCl} 2,20 \mathrm{mM}$ de cada nucleótido trifosfato, $200 \mathrm{ng}$ de cada oligonucleótido cebador y $1 \mathrm{U}$ de Taq polimerasa.

El producto de PCR tiene un tamaño de 298 bp. Después, $17 \mu 1$ de dicho producto de PCR se digirieron con $10 \mathrm{U}$ de la endonucleasa de restricción BstU-I (sitio de reconocimiento: $\left.5^{\prime} . . . \mathrm{CG}^{*} \mathrm{CG} . . .3^{\prime}\right)$ y $2 \mu 1$ del Buffer recomendado, a $60^{\circ} \mathrm{C}$ por $4 \mathrm{~h}$.

Se realizó la electroforesis en un gel de agarosa al 1.5\% conteniendo bromuro de etidio, visualizándose después mediante luz ultravioleta. Si existía un sitio de corte BstU-I (alelo Arginina) se observaban dos bandas, de 169 bp y de 129 bp. Genotipos posibles: 
- Un fragmento de 298 bp: Genotipo A2/A2

- Dos fragmentos de 169 bp y 129 bp: Genotipo A1/A1

- Tres fragmentos de 298 bp, 169 bp y 129 bp: Genotipo A1/A2

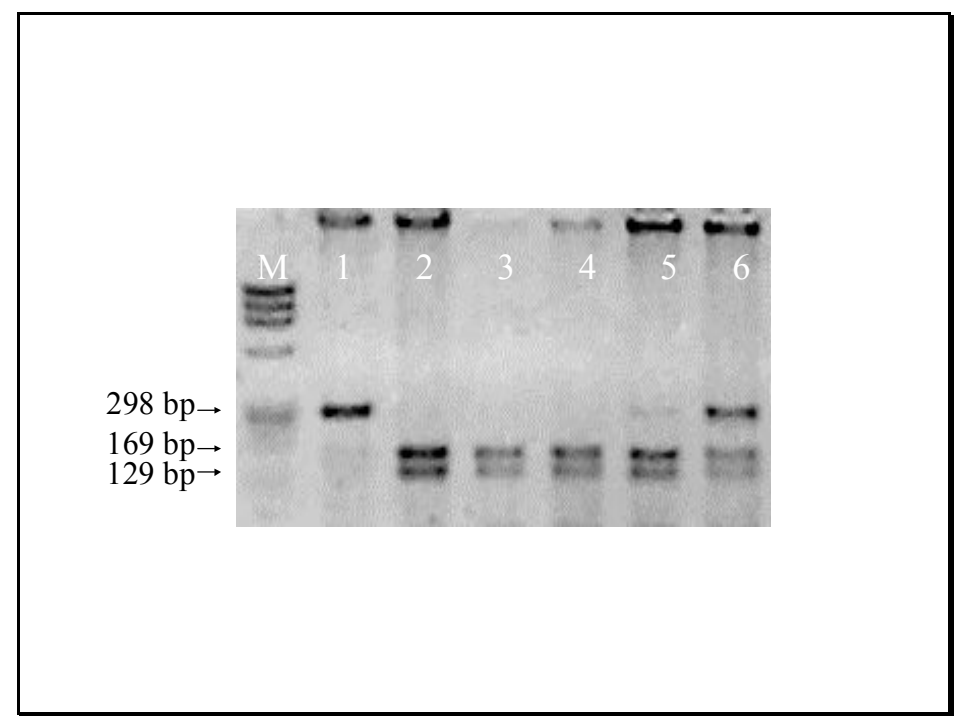

Fig. 15. Estudio del polimorfismo en el codón 72 del gen TP53.

Se observan los tres genotipos posibles, homocigoto Prolina (carril 1), homocigoto Arginina (carriles 2,3,4) y heterocigoto (5,6).

\section{5.- ESTUDIO DEL POLIMORFISMO DEL INTRON 3 DEL GEN P53, Arg194Trp DEL GEN XRCC1, y A19886G(Thr75) DEL GEN ERCC1.}

En el estudio del polimorfismo del Intrón 3 del gen P53 hemos realizado la discriminación alélica mediante la técnica DHPLC.

En el estudio de los polimorfismos de los genes XRCC1 y ERCC1 hemos realizado la discriminación alélica mediante PCR con sondas Taqman (Tabla 13). 
Tabla 13. Técnica de discriminación alélica en los polimorfismos de XRCC1 y ERCC1

\begin{tabular}{||c|c|c|c||}
\hline GEN & $\begin{array}{c}\text { MECANISMO DE } \\
\text { REPARACIÓN }\end{array}$ & POLIMORFISMO & $\begin{array}{c}\text { TÉCNICA DE } \\
\text { DISCRIMINACIÓN ALÉLICA }\end{array}$ \\
\hline \hline XRCC1 & BER & Arg194Try $(\mathrm{C}>\mathrm{T})$ & $\begin{array}{c}\text { Sondas Taqman } \\
\text { C_622564_10 }\end{array}$ \\
\hline ERCC1 & NER & A19886G(Thr75) & $\begin{array}{c}\text { Sondas Taqman } \\
\text { C_2532959 }\end{array}$ \\
\hline P53 & & Int3 Ins16pb & DHPLC \\
\hline
\end{tabular}

En la PCR con sondas Taqman los procesos de amplificación y detección se producen de manera simultánea en el mismo vial cerrado, sin necesidad de ninguna acción posterior. Además, mediante detección por fluorescencia se puede medir durante la amplificación la cantidad de ADN sintetizado en cada momento, ya que la emisión de fluorescencia producida en la reacción es proporcional a la cantidad de ADN formado. Esto permite conocer y registrar en todo momento la cinética de la reacción de amplificación. Los termocicladores para llevar a cabo la PCR con sondas Taqman incorporan un lector de fluorescencia y están diseñados para poder medir, en cualquier momento, la fluorescencia emitida en cada uno de los viales donde se realice la amplificación. Los sistemas de detección por fluorescencia empleados en la PCR con sondas Taqman pueden ser de dos tipos: agentes intercalantes y sondas específicas marcadas con fluorocromos.

Para la discriminación alélica nosotros hemos empleado sondas específicas marcadas con fluorocromos: Un donador en el extremo 5', que emite fluorescencia al ser excitado y un aceptor en el extremo 3', que absorbe la fluorescencia liberada por el donador. Para que esto ocurra, las moléculas donadora y aceptora deben estar espacialmente próximas. Además, el espectro de emisión de la primera se ha de solapar con el espectro de absorción de la segunda. En todos nuestros ensayos de discriminación alélica mediante PCR con sondas Taqman los fluorocromos empleados fueron VIC y FAM. 
Mientras la sonda está intacta, la fluorescencia emitida por el donador es absorbida por el aceptor. Sin embargo, durante la amplificación del ADN diana, la sonda se hibrida con su cadena complementaria. Al desplazarse a lo largo de la cadena, en su acción de síntesis, la ADN polimerasa de Thermus aquaticus, que tiene actividad 5' exonucleasa, hidroliza el extremo libre 5' de la sonda, produciéndose la liberación del fluorocromo donador. Como donador y aceptor están, espacialmente alejados, la fluorescencia emitida por el primero es captada por el lector (Figura 16).

El incremento de $\mathrm{ADN}$ en cada ciclo se corresponde con un aumento de hibridación de las sondas, lo que conlleva un aumento en la misma proporción de fluorescencia emitida. El empleo de estas sondas garantiza la especificidad de la detección y permite identificar polimorfismos o mutaciones puntuales.

Nuestro estudio se realizó en un termociclador de Applied Biosystems que dispone de varios canales de lectura y permite detectar la emisión de distintos fluorocromos a la vez. De esa manera, se pueden usar varias sondas marcadas con distintos fluorocromos, para identificar los diferentes alelos descritos en cada uno de los genes estudiados. (Figura 17)
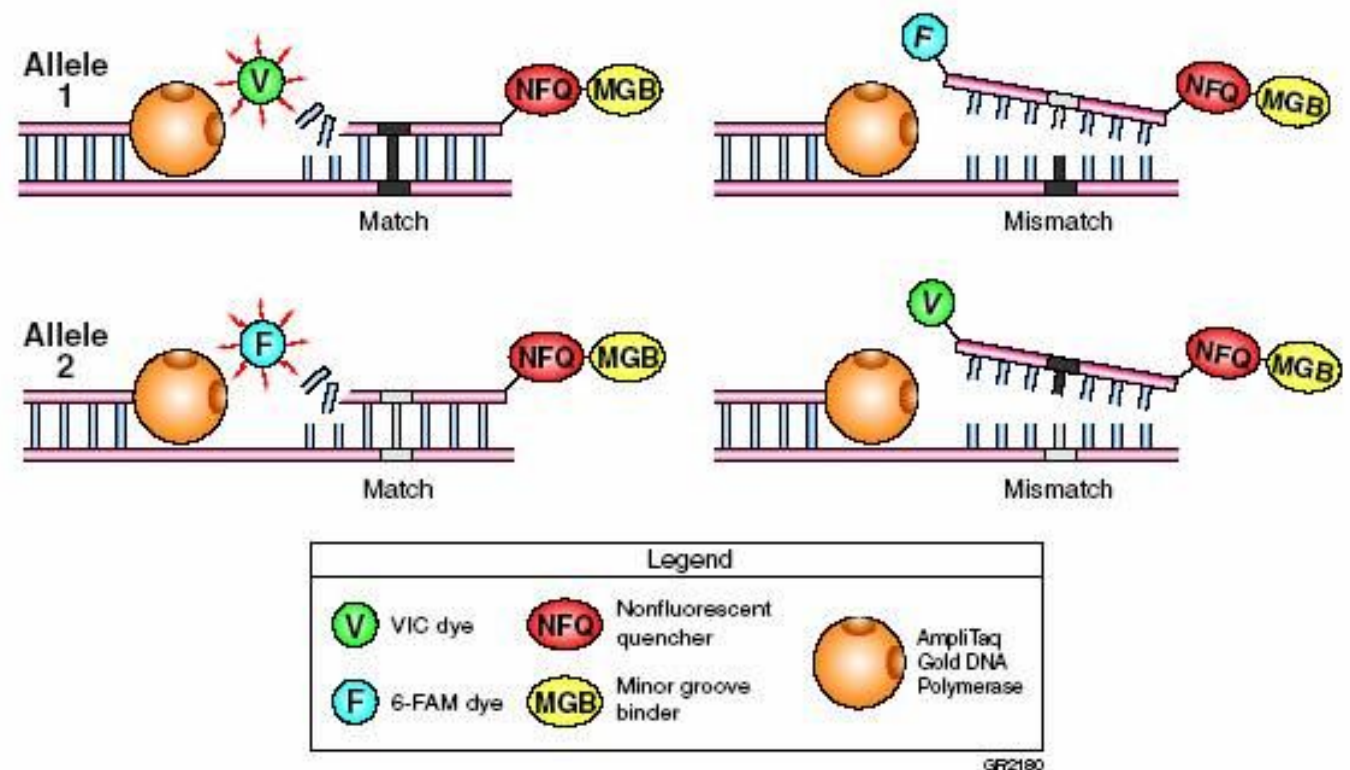

Figura 16. Mecanismo de la PCR con sondas Taqman. 


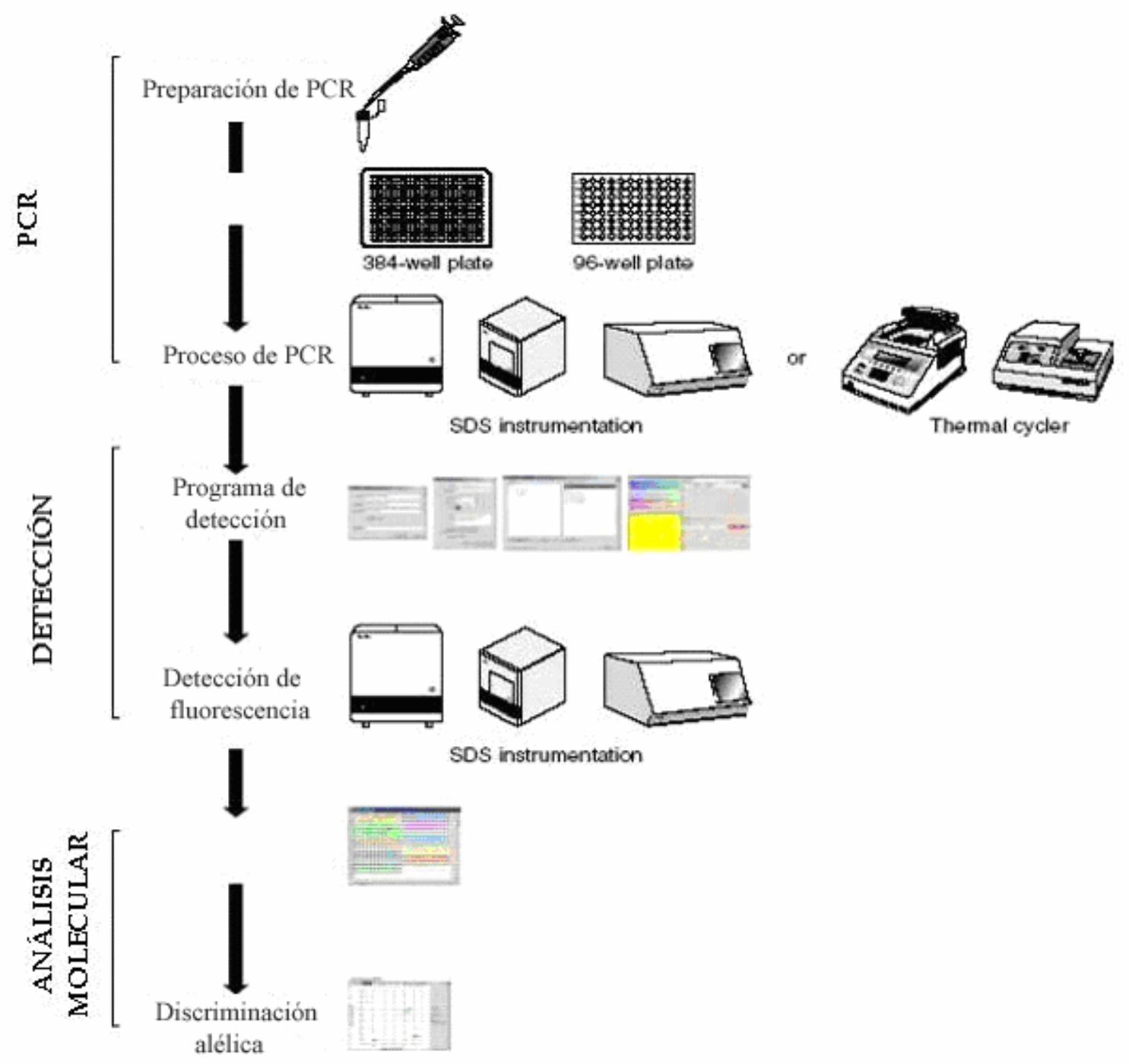

Figura 17. Discriminación alélica mediante PCR con sondas Taqman

\section{6. - METODOLOGÍA}

En el análisis de las variables no genéticas estudiadas en el grupo de pacientes con cáncer de pulmón hemos estudiado las siguientes asociaciones:

- Relaciones entre factores de riesgo. Entendiendo por factores de riesgo las variables demográficas y ambientales que presumiblemente pueden influir en que un pacientes desarrolle o no el cáncer. Se ven las relaciones dos a dos entre estos factores para 
comprobar la "calidad" de la muestra: habrá variables que deban estar relacionadas y otras en cambio que no deban estarlo.

- Relaciones de los factores de riesgo con las características del cáncer. Por cada una de las características del cáncer vemos su relación con cada uno de los factores de riesgo.

- Relaciones de los factores de riesgo con el tratamiento. Por cada una de las variables que describen el tratamiento que ha tenido el paciente vemos su relación con cada uno de los factores de riesgo.

- Respuesta. Vemos como influyen estos grupos de variables en la respuesta de los pacientes.

En el análisis de las variables no genéticas estudiadas en el grupo de pacientes fumadores sin cáncer de pulmón (grupo control) hemos estudiado las siguientes asociaciones:

- Relaciones entre factores de riesgo. Entendiendo por factores de riesgo las variables demográficas y ambientales que, presumiblemente pueden influir en que un pacientes desarrolle o no el cáncer. Vemos las relaciones que existen entre estas variables de dos en dos en cada uno de los grupos control por separado.

- Diferencias entre las dos muestras control. Comparamos las variables que se recogen en las dos muestras control.

- Diferencias entre el control y la muestra de casos. Dividimos estas diferencias en tres grupos:

- Grupo control con 65 años o más. Se comparan con los casos de cáncer de pulmón con edades en ese intervalo.

- Grupo control con menos de 65 años. Se comparan con los casos de cáncer de 
pulmón con edades en ese intervalo.

- En general. Se comparan con todos los casos de cáncer de pulmón.

- Influencia de los factores de riesgo en desarrollar o no cáncer de pulmón.

\section{7.- ESTUDIO DE ASOCIACIÓN GENÉTICA}

\section{1.- Equilibrio de Hardy Weinberg.}

La ley de equilibrio de Hardy y Weinberg es un modelo que predice la relación que debe existir entre frecuencias alélicas y frecuencias genotípicas en una población de características ideales, que debiera cumplir los siguientes supuestos:

a. La población debe ser grande y estable, preferiblemente de tamaño infinito.

b. No hay una muy marcada acción de la selección.

c. La población debe ser panmíctica, lo cual significa que el apareamiento de los individuos dentro de la población ocurre al azar (la probabilidad de cruzamiento con cualquier pareja potencial debe ser idéntica).

d. No debe existir mutación.

En estas circunstancias, para un locus dialélico, con dos alelos A y a, que en una población y una generación dadas muestran unas frecuencias génicas de p para el alelo A y de $\mathrm{q}$ para el alelo a y donde $\mathrm{p}+\mathrm{q}=1$, los gametos que se produzcan en ambos sexos portarán estos alelos con las mismas frecuencias y formarán cigotos con los diferentes genotipos en las siguientes frecuencias: 
Tabla 14.

\begin{tabular}{|c|c|c|c||}
\cline { 2 - 4 } \multicolumn{1}{c|}{} & \multicolumn{2}{c||}{ Espermatozoides } \\
\hline \multirow{2}{*}{ Óvulos } & $\mathrm{A}(\mathrm{p})$ & $\mathrm{A}(\mathrm{p})$ & $\mathrm{a}(\mathrm{q})$ \\
\cline { 2 - 4 } & $\mathrm{a}(\mathrm{q})$ & $\mathrm{pq}$ & $\mathrm{pq}$ \\
\hline
\end{tabular}

Los genotipos resultantes aparecerán por tanto en la nueva generación con las proporciones siguientes:

Tabla 15

\begin{tabular}{|c|c|}
\hline Genotipo & Frecuencia \\
\hline AA & $\mathrm{p}^{2}$ \\
\hline Aa & $2 \mathrm{pq}$ \\
\hline Aa & $\mathrm{q}^{2}$ \\
\hline Total & 1 \\
\hline
\end{tabular}

El método más sencillo para comprobar la existencia de equilibrio Hardy-Weinberg se basa en el test $\chi^{2}, \chi^{2}=\sum_{i} \frac{\left(O_{i}-E_{i}\right)^{2}}{E_{i}}$, donde $O_{i}$ son los individuos observados y $E_{i}$ son los individuos esperados que portan el genotipo $i$. El número de grados de libertad se calcula como el número de genotipos menos el número de alelos. Comprobamos esta hipótesis en los distintos grupos de pacientes para los distintos polimorfismos que se pretende analizar.

\section{2.- Tests de Asociación Genética.}

En este trabajo doctoral se realiza un estudio caso - control en el que se compara la frecuencia de los alelos de un SNP en dos grupos de individuos: casos, aquellos que han sido diagnosticados con la enfermedad y controles, individuos no afectados por la 
enfermedad. Una mayor frecuencia de un alelo o de un genotipo entre los casos comparado con los controles, indicaría que la presencia de ese alelo o genotipo puede incrementar el riesgo de padecer la enfermedad.

El análisis más natural de asociación entre el genotipo y si el individuo es caso o control es contrastar la hipótesis de no asociación en la tabla de contingencia 2x3 que contiene las frecuencias de cada uno de los 3 genotipos en los casos y en los controles. Para ello se puede utilizar el contraste chi-cuadrado de Pearson (con 2 grados de libertad) o el test exacto de Fisher. Lo que se hace en este caso es comparar los valores observados de cada genotipo con los valores esperados asumiendo que los casos y los controles tienen frecuencias genotípicas idénticas.

También es posible analizar este tipo de datos, asumiendo un modelo genético preestablecido. Se van a analizar los siguientes modelos:

a) Modelo dominante. Se hace la suposición de que portar un determinado alelo incrementa el riesgo de padecer la enfermedad.

b) Modelo recesivo. Se hace la suposición de que portar dos copias de un alelo incrementa el riesgo de padecer la enfermedad.

c) Modelo multiplicativo. Se trata de un análisis por alelos y no por genotipos, comparando el número total de alelos de cada tipo en casos y controles, independientemente del genotipo del que provengan. La hipótesis de este modelo es que el riesgo de padecer la enfermedad se incrementa en un valor fijo por cada alelo que se porte (por ejemplo, se incrementa por $\mathrm{r}$ el riesgo si se porta el alelo B, entonces, individuos con genotipo $\mathrm{AB}$ tendrán un riesgo $\mathrm{r}$ e individuos con genotipo $\mathrm{BB}, \mathrm{r} 2)$. Para que este modelo sea apropiado es muy importante que tanto los casos como los controles estén en equilibrio Hardy - Weinberg.

d) Modelo aditivo. La hipótesis de este modelo es que el riesgo de los heterocigotos $(\mathrm{AB})$ es la mitad del riesgo de los homocigotos. Los contrastes generales usados en 
tablas de contingencia, no tienen mucha potencia en este supuesto. Se utiliza el test de Cochran-Armitage para tendencias.

\section{3.- Test de Asociación: Múltiples SNP}

Analizar la asociación de cada uno de los SNP por separado puede ocultar información acerca de su distribución conjunta. Por ello se analiza la asociación entre la enfermedad y todos los SNP a la vez. Para cada SNP tenemos unos coeficientes $\left(\beta_{0}, \beta_{1}, \beta_{2}\right)$ que nos permiten realizar el contraste general $\beta_{0}=\beta_{1}=\beta_{2}$ en cada caso.

Ajustamos un modelo de regresión logística para todos los SNP a la vez incluyendo las interacciones entre los mismos, y empleamos un procedimiento de selección "stepwise" para determinar que SNP están más relaciones con el hecho de padecer o no cáncer de pulmón.

\section{4.- Regresión Logística.}

Una manera más "sofisticada" de ver si existe o no asociación entre la enfermedad y el SNP es ajustar un modelo de regresión logística. Se ajusta un modelo del tipo:

$$
\log i t(\pi)=\log \left(\frac{\pi}{1-\pi}\right)=\beta_{0}+\beta_{1} X_{1}+\beta_{2} X_{2}
$$

donde $\pi$ es el riesgo de padecer la enfermedad y, $X_{1}$ y $X_{2}$ son variables que en cada individuo toma el valor 1 si en el SNP es un homocigoto (AA en para $X_{1}$ y BB para $X_{2}$ ) y 0 en caso contrario.

El test de razón de verosimilitud (TRV) para el modelo general que contrasta la hipótesis nula $\beta_{0}=\beta_{1}=\beta_{2}$, tiene 2 grados de libertad, y para muestras grandes es equivalente al contraste chi-cuadrado de Pearson utilizado en la sección anterior. En las tablas este contraste se presenta en la fila encabezada por el nombre del SNP. 
Para cada coeficiente se presentan los contrastes de Wald correspondientes a la hipótesis nula $\beta_{i}=0$. Considerando la odds como $\frac{\pi}{1-\pi}$, se puede interpretar cada uno de estos coeficientes como cuantificadores del riesgo de padecer la enfermedad de la siguiente forma:

- $\beta_{0}$ o constante, es el logaritmo de la odds cuando $X_{1}$ y $X_{2}$ son 0 , es decir que la $\exp \left\{\beta_{0}\right\}$ es el cociente de la probabilidad de que un paciente enferme y de que no enferme cuando es heterocigoto en el SNP correspondiente. Así, si es mayor que 1, ser heterocigoto es un factor de riesgo de la enfermedad (individuos heterocigotos tienen más probabilidad de enfermar) y si es menor un factor de protección (individuos heterocigotos tienen más probabilidad de no enfermar)

- $\beta_{1}$, es el logaritmo de la odds-ratio (OR) para los dos valores de la variable ${ }^{X_{1}}$, es decir que cuantifica el riesgo de padecer la enfermedad cuando se es AA en el SNP correspondiente respecto de ser AB. En términos de OR medimos la significatividad estadística a partir de los intervalos de confianza (IC) del 95\%, para que la asociación sea significativa el IC para la OR no debe contener al 1.

- $\beta_{2}$, es el logaritmo de la OR para los dos valores de la variable $X_{2}$, es decir que cuantifica el riesgo de padecer la enfermedad cuando se es BB en el SNP correspondiente respecto de ser $\mathrm{AB}$.

Los resultados que se obtienen con este método son los mismos que en la sección anterior. Sin embargo aporta beneficios a la hora de considerar varios SNP a la vez o incluir covariables.

\section{8.- ANÁLISIS ESTADÍSTICO DE LOS RESULTADOS.}

Hemos analizado si existen relaciones entre pares de variables. En función del tipo de variable hemos utilizado diferentes modelos de análisis estadísticos: 
- Si las dos variables son cualitativas: utilizamos el análisis de tablas de contingencia, con el test chi-cuadrado y el Fiher

- Si una variable es cualitativa y la otra cuantitativa: utilizamos comparaciones de grupos, bien los contrastes de dos muestras independientes tipo t-Student o su análogo no paramétrico U de Mann Whitney; o un ANOVA, ya sea parámetrico o no, si hay más de dos grupos. Previamente comprobamos la hipótesis de normalidad a partir del contraste de Kolmogorov-Smirnov y la hipótesis de homogeneidad de varianzas en los grupos a partir del estadístico de Levene.

- Si las dos variables son cuantitativas: utilizamos coeficientes de correlación, el coeficiente de correlación lineal de Pearson y su análogo no paramétrico de Spearman.

En el grupo de pacientes con cáncer de pulmón, cuando estudiamos la respuesta, además de las relaciones de cada par de variables, analizamos la relación de la respuesta con el resto de variables que resulten significativas de forma individual, utilizando el mejor modelo loglineal jerárgico para analizar la relación entre más de dos variables cualitativas.

Para ver si existen diferencias entre dos muestras en una variable hacemos lo siguiente:

- En el caso de que la variable sea cualitativa, la metodología se correspondería con el primer punto del apartado anterior, en donde una de las variables es la muestra a la que pertenece el individuo.

- En el caso de que la variable sea cuantitativa la metodología se correspondería con el segundo punto del apartado anterior, en donde la variable cualitativa es la muestra a la que pertenece el individuo.

Para ver la influencia de los factores de riesgo en el hecho de desarrollar cáncer 
de pulmón, ajustamos un modelo de regresión logística en donde la variable dependiente es si el individuo desarrolla o no cáncer de pulmón y las variables independientes los factores de riesgo. Para seleccionar las variables que más entran en el modelo, utilizamos el algoritmo forward (hacia atrás). Este algoritmo consiste en introducir, en un primer paso, todas las variables en el modelo y en cada paso ir eliminando la variable que menos influye en el hecho de que un paciente desarrolle o no cáncer de pulmón. 


\section{4.- RESULTADOS}




\section{1.- ANALISIS DE LAS VARIABLES NO GENETICAS}

\section{1.- GRUPO DE PACIENTES CON CANCER DE PULMON}

De los pacientes con cáncer de pulmón que hemos incluido en este estudio, prácticamente el $90 \%$ eran de estirpe histológica compatible con carcinoma no microcítico y un $10 \%$ de variante microcítica (Tabla 16). Esto concuerda con los datos epidemiológicos de distribución de subtipos histológicos descrita en la literatura.

Tabla 16. Subtipos histológicos de los pacientes con cáncer de pulmón incluidos en el estudio

\begin{tabular}{|l|c|}
\hline \multicolumn{1}{|c|}{ Subtipos Histológicos } & $\boldsymbol{N}^{\boldsymbol{o}}$ \\
\hline \hline ADC & 37 \\
\hline Epiderm & 59 \\
\hline Cs. Grandes & 9 \\
\hline Otros no microcit & 9 \\
\hline Microcitico & 12 \\
\hline Otros & 4 \\
\hline Total & 130 \\
\hline
\end{tabular}

Hemos encontrado las siguientes relaciones significativas entre los factores de riesgo:

\section{I.- Sexo}

- Por cada mujer fumadora hay 4 hombres que son fumadores, si bien hemos estudiado a 132 hombres y 14 mujeres.

- De media los hombres están más años fumando (38, 44 años frente a 27, 25 años).

- De media las mujeres dejan de fumar a edades más tempranas (57,06 años frente a 45,75 años). 


\section{II.- Edad en el diagnóstico}

- De media, a los fumadores se les diagnostica el cáncer con edades más tempranas

Tabla 17. Edad al diagnóstico según grupo fumador o no.

\begin{tabular}{|c|c|c|c|c|c|c|c|c|}
\hline & \multirow{2}{*}{$N^{o}$} & \multirow{2}{*}{ Media } & \multirow{2}{*}{$\begin{array}{c}\text { Desviación } \\
\text { típica }\end{array}$} & \multirow{2}{*}{$\begin{array}{l}\text { Error } \\
\text { típico }\end{array}$} & \multicolumn{2}{|c|}{$\begin{array}{l}\text { Intervalo de confianza } \\
\text { para la media al } 95 \%\end{array}$} & \multirow{2}{*}{ Mínimo } & \multirow{2}{*}{ Máximo } \\
\hline & & & & & $\begin{array}{l}\text { Límite } \\
\text { inferior }\end{array}$ & $\begin{array}{l}\text { Límite } \\
\text { superior }\end{array}$ & & \\
\hline Sí & 132 & 63,29 & 10,839 &, 943 & 61,42 & 65,15 & 32 & 85 \\
\hline No & 14 & 69,50 & 6,035 & 1,613 & 66,02 & 72,98 & 57 & 78 \\
\hline Total & 146 & 63,88 & 10,620 &, 879 & 62,15 & 65,62 & 32 & 85 \\
\hline
\end{tabular}

- De media, a los pacientes que fuman negro se les diagnostica el cáncer con edades más avanzadas

Tabla 18. Edad al diagnóstico según el tipo de tabaco

\begin{tabular}{|c|c|c|c|c|c|c|c|c|}
\hline & \multirow{2}{*}{$N^{o}$} & \multirow{2}{*}{ Media } & \multirow{2}{*}{$\begin{array}{c}\text { Desviación } \\
\text { típica }\end{array}$} & \multirow{2}{*}{$\begin{array}{l}\text { Error } \\
\text { típico }\end{array}$} & \multicolumn{2}{|c|}{$\begin{array}{l}\text { Intervalo de confianza } \\
\text { para la media al } 95 \%\end{array}$} & \multirow{2}{*}{ Mínimo } & \multirow{2}{*}{ Máximo } \\
\hline & & & & & $\begin{array}{l}\text { Límite } \\
\text { inferior }\end{array}$ & $\begin{array}{c}\text { Límite } \\
\text { superior }\end{array}$ & & \\
\hline Negro & 98 & 64,91 & 10,394 & 1,050 & 62,82 & 66,99 & 32 & 85 \\
\hline Rubio & 22 & 59,14 & 10,593 & 2,259 & 54,44 & 63,83 & 40 & 78 \\
\hline Los dos & 12 & 57,67 & 11,827 & 3,414 & 50,15 & 65,18 & 33 & 75 \\
\hline Total & 132 & 63,29 & 10,839 &, 943 & 61,42 & 65,15 & 32 & 85 \\
\hline
\end{tabular}


- Los pacientes diagnosticados en edad más avanzada han estado más años fumando.

La correlación entre las dos variables es positiva y muy significativa. Gráficamente:

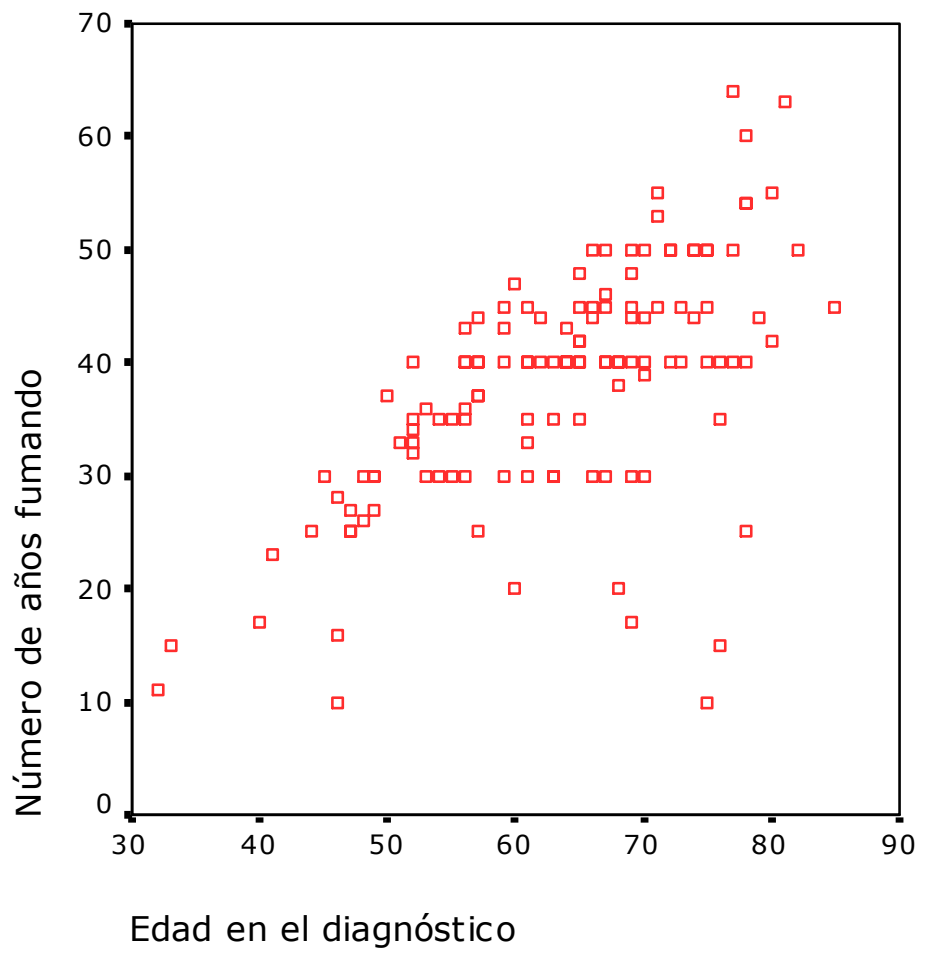

- Como cabía esperar, a mayor edad más tardan en dejar de fumar.

\section{III.- Tipo de profesión (riesgo, no riesgo)}

- Entre pacientes con profesiones clasificadas como de riesgo hay más casos con antecedentes de EPOC.

Tabla 19. Tabla de contingencia que relaciona el tipo de profesión(Riesgo/No Riesgo) $y$ antecedentes de EPOC

\begin{tabular}{|c|c|c|c|c|}
\hline & & \multicolumn{2}{|c|}{ EPOC } & \multirow{2}{*}{ Total } \\
\hline & & Sí & No & \\
\hline \multirow{2}{*}{ Profesión } & Riesgo & $10(47,61 \%)$ & $11(52,39 \%)$ & $21 \quad(100 \%)$ \\
\hline & No riesgo & $22(20 \%)$ & $88(80 \%)$ & $110(100 \%)$ \\
\hline \multicolumn{2}{|c|}{ Total } & 32 & 99 & 131 \\
\hline
\end{tabular}

Estudio de los polimorfismos de genes reparadores en población fumadora con y sin cáncer de pulmón 
- Para evaluar la cantidad de asociación utilizamos los estimadores de riesgo.

Tabla 20. Razón de las ventajas para Tipo de profesión (Riesgo/No riesgo) según antecedentesde EPOC

\begin{tabular}{|c|c|c|c|}
\hline & \multirow{2}{*}{ Valor } & \multicolumn{2}{|c|}{ Intervalo de confianza al $95 \%$} \\
\hline & & Inferior & Superior \\
\hline $\begin{array}{l}\text { Razón de las ventajas para Tipo de profesión } \\
\text { (Riesgo/No riesgo) }\end{array}$ & 3,636 & 1,371 & 9,646 \\
\hline Para la cohorte Antecedentes de EPOC $=S i$ & 2,381 & 1,328 & 4,269 \\
\hline Para la cohorte Antecedentes de EPOC $=$ No &, 655 & ,431 & ,995 \\
\hline$N^{o}$ de casos válidos & 131 & & \\
\hline
\end{tabular}

En la muestra de pacientes con cáncer de pulmón es más probable encontrarse que los pacientes con profesiones de riesgo tengan antecedentes de EPOC: por cada paciente con profesión no de riesgo con antecedentes de EPOC hay 2 pacientes con profesión de riesgo.

\section{IV.- Antecedentes de EPOC.}

- De media, los pacientes con antecedentes de EPOC fuman más paquetes al día.

Tabla 21. Media de paquetes/día según antecedente de EPOC

\begin{tabular}{|c|c|c|c|c|c|c|c|c|}
\hline & \multirow{2}{*}{$N$} & \multirow{2}{*}{ Media } & \multirow{2}{*}{$\begin{array}{c}\text { Desviación } \\
\text { típica }\end{array}$} & \multirow{2}{*}{$\begin{array}{l}\text { Error } \\
\text { típico }\end{array}$} & \multicolumn{2}{|c|}{$\begin{array}{c}\text { Intervalo de confianza } \\
\text { para la media } 95 \%\end{array}$} & \multirow{2}{*}{ Mínimo } & \multirow{2}{*}{ Máximo } \\
\hline & & & & & $\begin{array}{l}\text { Límite } \\
\text { inferior }\end{array}$ & $\begin{array}{c}\text { Límite } \\
\text { superior }\end{array}$ & & \\
\hline Sí & 38 & 1,776 & ,6335 &, 1028 & 1,568 & 1,985 &, 5 & 3,0 \\
\hline No & 94 & 1,481 & ,5979 &, 0617 & 1,358 & 1,603 &, 2 & 3,0 \\
\hline Total & 132 & 1,566 & 6206 & 0540 & 1,459 & 1,673 & 2 & 3,0 \\
\hline
\end{tabular}




\section{V.- Antecedentes familiares oncológicos}

- De media, los pacientes con antecedentes familiares oncológicos fuman más paquetes al día

Tabla 22. Media de paquetes/día según antecedente familiares oncológicos.

\begin{tabular}{|c|c|c|c|c|c|c|c|c|}
\hline & \multirow{2}{*}{$N$} & \multirow{2}{*}{ Media } & \multirow{2}{*}{$\begin{array}{c}\text { Desviación } \\
\text { típica }\end{array}$} & \multirow{2}{*}{$\begin{array}{l}\text { Error } \\
\text { típico }\end{array}$} & \multicolumn{2}{|c|}{$\begin{array}{l}\text { Intervalo de confianza } \\
\text { para la media al } 95 \%\end{array}$} & \multirow{2}{*}{ Mínimo } & \multirow{2}{*}{ Máximo } \\
\hline & & & & & $\begin{array}{c}\text { Límite } \\
\text { inferior }\end{array}$ & $\begin{array}{c}\text { Límite } \\
\text { superior }\end{array}$ & & \\
\hline$\overline{S i ́}$ & 55 & 1,731 &, 6110 & ,0824 & 1,566 & 1,896 &, 5 & 3,0 \\
\hline No & 76 & 1,454 & 6058 & ,0695 & 1,316 & 1,592 &, 2 & 3,0 \\
\hline Total & 131 & 1,570 & 6210 & ,0543 & 1,463 & 1,678 & 2 & 3,0 \\
\hline
\end{tabular}

- Los pacientes con antecedentes familiares oncológicos dejan de fumar a edades más tempranas

Tabla 23. Edad a la que se deja de fumar según los antecedentes familiares oncológicos

\begin{tabular}{|c|c|c|c|c|c|c|c|c|}
\hline & \multirow{2}{*}{$N$} & \multirow{2}{*}{ Media } & \multirow{2}{*}{$\begin{array}{c}\text { Desviación } \\
\text { típica }\end{array}$} & \multirow{2}{*}{$\begin{array}{l}\text { Error } \\
\text { típico }\end{array}$} & \multicolumn{2}{|c|}{$\begin{array}{l}\text { Intervalo de confianza } \\
\text { para la media al } 95 \%\end{array}$} & \multirow{2}{*}{ Mínimo } & \multirow{2}{*}{ Máximo } \\
\hline & & & & & $\begin{array}{l}\text { Límite } \\
\text { inferior }\end{array}$ & $\begin{array}{l}\text { Límite } \\
\text { superior }\end{array}$ & & \\
\hline$\overline{S i ́}$ & 54 & 54,56 & 10,792 & 1,469 & 51,61 & 57,50 & 29 & 77 \\
\hline No & 74 & 58,28 & 10,236 & 1,190 & 55,91 & 60,66 & 30 & 77 \\
\hline Total & 128 & 56,71 & 10,595 & ,936 & 54,86 & 58,56 & 29 & 77 \\
\hline
\end{tabular}

\section{VI.- Número de años fumando}

- Los pacientes que llevan más años fumando lo han dejado con mayor edad. En dos de los pacientes se perdieron los datos de la edad a la que dejaba de fumar. 
Tabla 24. Edad a la que se deja de fumar según número de años fumando.

\begin{tabular}{|c|c|c|c|c|c|c|c|c|}
\hline & \multirow{2}{*}{$N$} & \multirow{2}{*}{ Media } & \multirow{2}{*}{$\begin{array}{c}\text { Desviación } \\
\text { típica }\end{array}$} & \multirow{2}{*}{$\begin{array}{l}\text { Error } \\
\text { típico }\end{array}$} & \multicolumn{2}{|c|}{$\begin{array}{c}\text { Intervalo de confianza } \\
\text { para la media } 95 \%\end{array}$} & \multirow{2}{*}{ Mínimo } & \multirow{2}{*}{ Máximo } \\
\hline & & & & & $\begin{array}{l}\text { Límite } \\
\text { inferior }\end{array}$ & $\begin{array}{l}\text { Límite } \\
\text { superior }\end{array}$ & & \\
\hline Años fumando & 132 & 38,10 & 10,532 &, 917 & 36,29 & 39,91 & 10 & 64 \\
\hline Edad lo deja & 130 & 56,71 & 10,566 & ,927 & 54,87 & 58,54 & 29 & 77 \\
\hline
\end{tabular}

- La correlación entre las dos variables es positiva y muy significativa. Gráficamente,

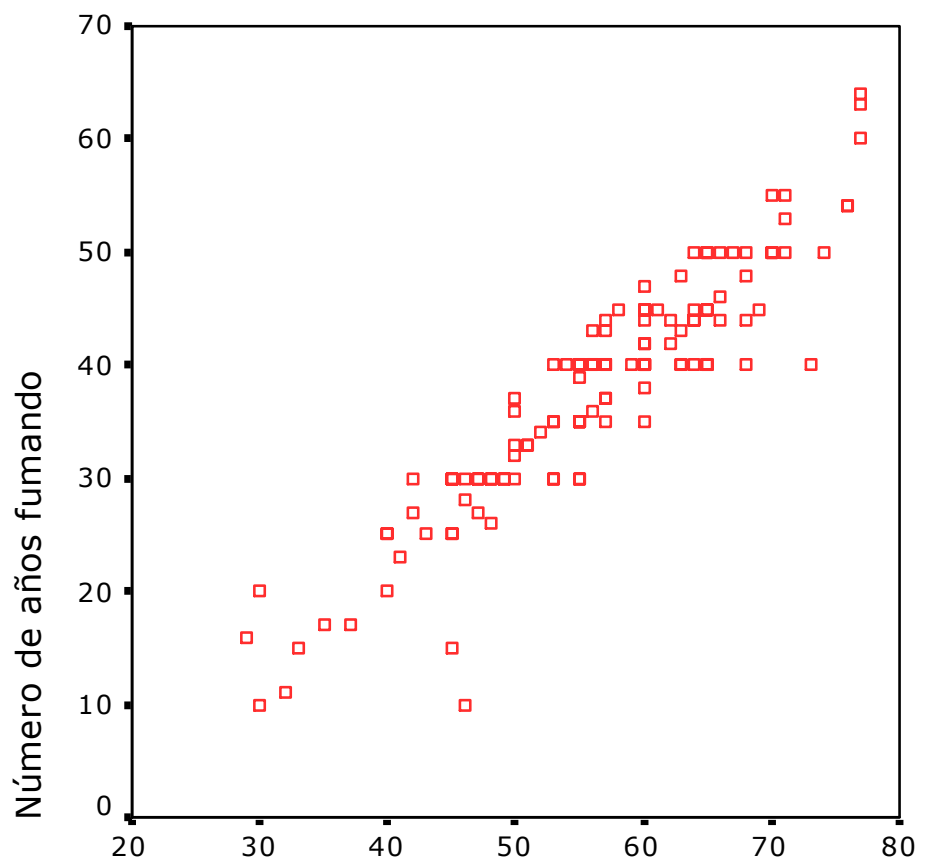

Edad a la que deja de fumar

En cuanto a las relaciones de los factores de riesgo con las características del cáncer, con el tratamiento y con la respuesta, si bien hemos encontrado alguna relación significativa, estas no son relevantes. Únicamente destacatar, en relación a la histología, que los pacientes con cáncer no microcítico de pulmón comienzan a fumar más jóvenes que aquellos con cáncer microcítico, tal y como se muestra en la siguiente tabla. 
Tabla 25. Edad de inicio del hábito tabáquico según el tipo histológico de tumor.

\begin{tabular}{|c|c|c|c|c|c|c|c|c|}
\hline & \multirow[t]{2}{*}{$N$} & \multirow[t]{2}{*}{ Media } & \multirow{2}{*}{$\begin{array}{c}\text { Desviación } \\
\text { típica }\end{array}$} & \multirow{2}{*}{$\begin{array}{l}\text { Error } \\
\text { típico }\end{array}$} & \multicolumn{2}{|c|}{$\begin{array}{c}\text { Intervalo de confianza } \\
\text { para la media al } 95 \%\end{array}$} & \multirow[t]{2}{*}{ Mínimo } & \multirow[t]{2}{*}{ Máximo } \\
\hline & & & & & $\begin{array}{l}\text { Límite } \\
\text { inferior }\end{array}$ & $\begin{array}{c}\text { Límite } \\
\text { superior }\end{array}$ & & \\
\hline No mic. & 116 & 18,52 & 3,766 &, 350 & 17,82 & 19,21 & 10 & 36 \\
\hline Mic. & 14 & 22,14 & 7,675 & 2,051 & 17,71 & 26,57 & 14 & 45 \\
\hline Total & 130 & 18,91 & 4,456 & 391 & 18,13 & 19,68 & 10 & 45 \\
\hline
\end{tabular}

Tabla 26. Edad de inicio del hábito tabáquico según la histología tumoral (por subgrupos)

\begin{tabular}{|c|c|c|c|c|c|c|c|c|}
\hline & \multirow[t]{2}{*}{$N$} & \multirow{2}{*}{ Media } & \multirow{2}{*}{$\begin{array}{c}\text { Desviación } \\
\text { típica }\end{array}$} & \multirow{2}{*}{$\begin{array}{l}\text { Error } \\
\text { típico }\end{array}$} & \multicolumn{2}{|c|}{$\begin{array}{c}\text { Intervalo de confianza } \\
\text { para la media } 95 \%\end{array}$} & \multirow{2}{*}{ Mínimo } & \multirow{2}{*}{ Máximo } \\
\hline & & & & & $\begin{array}{l}\text { Límite } \\
\text { inferior }\end{array}$ & $\begin{array}{c}\text { Límite } \\
\text { superior }\end{array}$ & & \\
\hline$A D C$ & 37 & 18,68 & 4,546 &, 747 & 17,16 & 20,19 & 10 & 36 \\
\hline Epiderm & 59 & 18,53 & 3,441 &, 448 & 17,63 & 19,42 & 13 & 25 \\
\hline Cs. Grandes & 9 & 17,22 & 3,528 & 1,176 & 14,51 & 19,93 & 13 & 23 \\
\hline $\begin{array}{l}\text { Otros no } \\
\text { microcit }\end{array}$ & 9 & 18,89 & 3,480 & 1,160 & 16,21 & 21,56 & 13 & 25 \\
\hline Microcitico & 12 & 23,00 & 7,897 & 2,280 & 17,98 & 28,02 & 16 & 45 \\
\hline otros & 4 & 18,25 & 1,708 &, 854 & 15,53 & 20,97 & 16 & 20 \\
\hline Total & 130 & 18,91 & 4,456 & ,391 & 18,13 & 19,68 & 10 & 45 \\
\hline
\end{tabular}




\section{2.- GRUPO DE PACIENTES SIN CANCER DE PULMON}

Hemos encontrado las siguientes relaciones significativas entre los factores de riesgo:

\subsection{1.- CONTROLES DE 65 AÑOS O MÁS}

\section{I.- Edad}

- La relación entre la edad y la edad en la que se deja de fumar está al borde de la significación. Como cabe esperar esta relación es positiva, es decir que cuanto mayor es el sujeto más tarde ha dejado de fumar.

Tabla 27. Media de las edades de los pacientes y de la edad a la que dejan de fumar

\begin{tabular}{|c|c|c|c|c|c|c|c|c|}
\hline & \multirow{2}{*}{$N^{o}$} & \multirow{2}{*}{ Media } & \multirow{2}{*}{$\begin{array}{c}\text { Desviación } \\
\text { típica }\end{array}$} & \multirow{2}{*}{$\begin{array}{l}\text { Error } \\
\text { típico }\end{array}$} & \multicolumn{2}{|c|}{$\begin{array}{c}\text { Intervalo de confianza } \\
\text { para la media } 95 \%\end{array}$} & \multirow{2}{*}{ Mínimo } & \multirow{2}{*}{ Máximo } \\
\hline & & & & & $\begin{array}{c}\text { Límite } \\
\text { inferior }\end{array}$ & $\begin{array}{c}\text { Límite } \\
\text { superior }\end{array}$ & & \\
\hline Edad & 151 & 76,26 & 6,082 &, 495 & 75,28 & 77,24 & 65 & 98 \\
\hline Edad no fuma & 151 & 62,03 & 9,939 & 809 & 60,43 & 63,63 & 35 & 85 \\
\hline
\end{tabular}

Gráficamente:

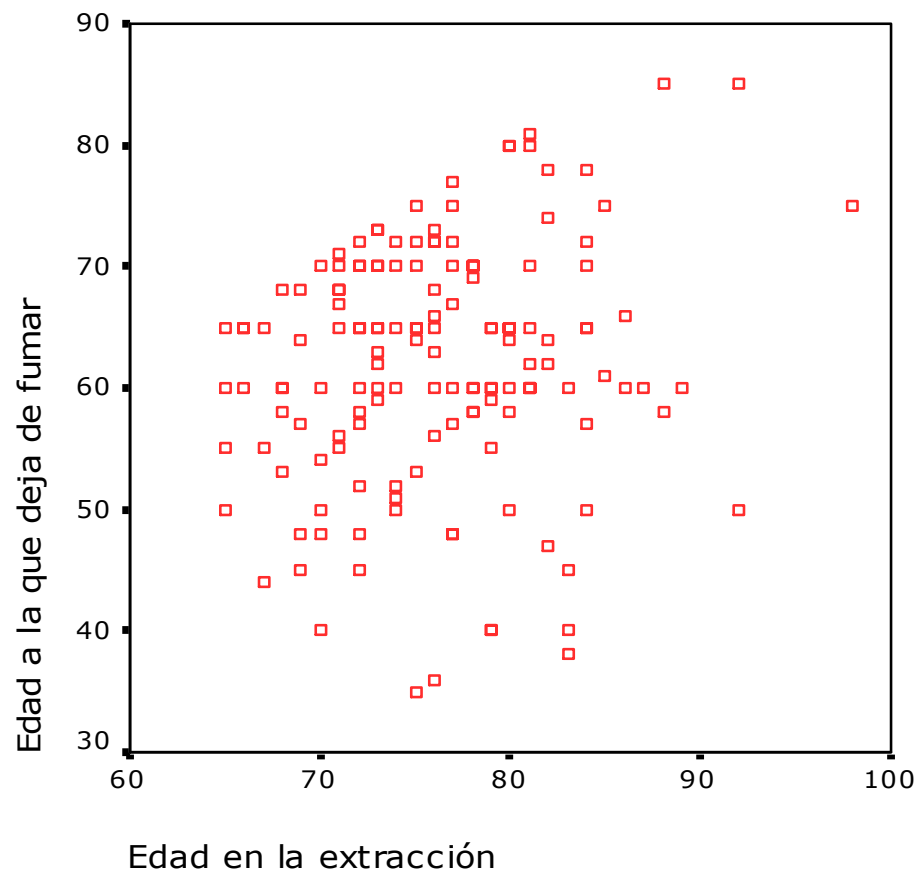

Estudio de los polimorfismos de genes reparadores en población fumadora con y sin cáncer de pulmón 
- Como cabía esperar, a mayor edad más tardan en dejar de fumar.

\section{II.- Lugar de residencia}

- Es más frecuente que sujetos que viven en el medio urbano tengan antecedentes de EPOC.

Tabla 28. Tabla de contingencia en función del lugar de residencia y antecedentes de EPOC

\begin{tabular}{|c|c|c|c|c||}
\cline { 3 - 4 } \multicolumn{1}{c|}{} & \multicolumn{2}{c|}{ EPOC } & \multirow{2}{*}{ Total } \\
\cline { 3 - 5 } \multicolumn{2}{c|}{} & Sí & No & \\
\hline \multirow{2}{*}{ Residencia } & Urbano & $21(38,18 \%)$ & $34(61,81)$ & $55(100 \%)$ \\
\cline { 2 - 5 } & Rural & $22(22,91)$ & $74(77,08 \%)$ & $96(100 \%)$ \\
\hline \multicolumn{2}{|r|}{ Total } & 43 & 108 & 151 \\
\hline
\end{tabular}

\section{III.- Tipo de profesión}

- Es más probable tener sujetos con antecedentes de EPOC entre los individuos con profesiones de riesgo.

Tabla 29. Tabla de contingencia que relaciona los antecedentes de EPOC y la profesión

\begin{tabular}{|c|c|c|c|c|}
\hline & \multicolumn{2}{|c|}{$\overline{E P O C}$} & \multirow{2}{*}{ Total } \\
\hline & & Sí & No & \\
\hline \multirow{2}{*}{ Profesión } & Riesgo & $11(50 \%)$ & $11(50 \%)$ & $22 \quad(100 \%)$ \\
\hline & No riesgo & $32(24,80)$ & $97(75,19 \%)$ & $129(100 \%)$ \\
\hline \multicolumn{2}{|c|}{ Total } & 43 & 108 & 151 \\
\hline
\end{tabular}

- También se ha observado que los individuos con profesiones de riesgo fuman menos años, dejando de fumar más jóvenes. 


\section{IV.- Antecedentes de EPOC}

- De media, los individuos con antecedentes de EPOC empiezan a fumar de más mayores.

Tabla 30. Edad de inicio al hábito tabáquico en función de los antecedentes de EPOC

\begin{tabular}{|c|c|c|c|c|c|c|c|c|}
\hline & \multirow{2}{*}{$N$} & \multirow{2}{*}{ Media } & \multirow{2}{*}{$\begin{array}{c}\text { Desviación } \\
\text { típica }\end{array}$} & \multirow{2}{*}{$\begin{array}{l}\text { Error } \\
\text { típico }\end{array}$} & \multicolumn{2}{|c|}{$\begin{array}{l}\text { Intervalo de confianza } \\
\text { para la media al } 95 \%\end{array}$} & \multirow{2}{*}{ Mínimo } & \multirow{2}{*}{ Máximo } \\
\hline & & & & & $\begin{array}{l}\text { Limite } \\
\text { inferior }\end{array}$ & $\begin{array}{l}\text { Límite } \\
\text { superior }\end{array}$ & & \\
\hline$S i$ & 43 & 18,70 & 5,045 & ,769 & 17,14 & 20,25 & 12 & 45 \\
\hline No & 108 & 17,29 & 3,273 & ,315 & 16,66 & 17,91 & 11 & 30 \\
\hline Total & 151 & 17,69 & 3,896 & ,317 & 17,06 & 18,32 & 11 & 45 \\
\hline
\end{tabular}

\section{V.- Antecedentes familiares oncológicos}

- Es más probable fumar negro entre los sujetos con antecedentes familiares oncológicos.

Tabla 31. Tabla de contingencia que relaciona los antecedentes familiares oncológicos y el tipo de tabaco

\begin{tabular}{|c|c|c|c|c|c||}
\cline { 3 - 6 } \multicolumn{1}{c|}{} & \multicolumn{3}{c|}{ Tipo de tabaco que fuma } & \multirow{2}{*}{ Total } \\
\cline { 3 - 6 } \multicolumn{2}{c|}{} & Negro & Rubio & Negro y Rubio & \\
\hline \multirow{2}{*}{$\begin{array}{c}\text { Antecedentes } \\
\text { familiares onco }\end{array}$} & $\boldsymbol{S i}$ & $53(91,37 \%)$ & $1(1,72 \%)$ & $4(6,89 \%)$ & $58(100 \%)$ \\
\cline { 2 - 6 } & $\mathrm{No}$ & $79(84,94 \%)$ & $13(13,97 \%)$ & $1(1,07 \%)$ & $93(100 \%)$ \\
\hline \multicolumn{2}{|c|}{ Total } & 132 & 14 & 5 & 151 \\
\hline
\end{tabular}

- Los individuos sin antecedentes familiares oncológicos fuman más cigarrillos al día.

Esta relación está al borde de la significación estadística. 
Tabla 32. Numero de paquetes/dia según los antecedentes familiares oncológicos.

\begin{tabular}{|c|c|c|c|c|c|c|c|c|}
\hline & \multirow{2}{*}{$N$} & \multirow{2}{*}{ Media } & \multirow{2}{*}{$\begin{array}{l}\text { Desviación } \\
\quad \text { típica }\end{array}$} & \multirow{2}{*}{$\begin{array}{l}\text { Error } \\
\text { típico }\end{array}$} & \multicolumn{2}{|c|}{$\begin{array}{l}\text { Intervalo de confianza } \\
\text { para la media al } 95 \%\end{array}$} & \multirow{2}{*}{ Mínimo } & \multirow{2}{*}{ Máximo } \\
\hline & & & & & $\begin{array}{l}\text { Límite } \\
\text { inferior }\end{array}$ & $\begin{array}{l}\text { Límite } \\
\text { superior }\end{array}$ & & \\
\hline$\overline{\overline{S i}}$ & 58 & 1,252 & , 4791 & ,0629 & 1,126 & 1,378 & , 5 & 3,0 \\
\hline$N o$ & 93 & 1,432 &, 5922 &, 0614 & 1,310 & 1,554 & 1,0 & 3,0 \\
\hline Total & 151 & 1,363 & ,5569 &, 0453 & 1,273 & 1,452 &, 5 & 3,0 \\
\hline
\end{tabular}

\section{VI.- Número de años fumando}

- Cuanto más joven se comienza a fumar más años se fuma.

Tabla 33. Edad de inicio al hábito tabáquico y número de años fumando

\begin{tabular}{|c|c|c|c|c|c|c|c|c|}
\hline & \multirow{2}{*}{$\boldsymbol{N}$} & \multirow{2}{*}{ Media } & \multirow{2}{*}{$\begin{array}{c}\text { Desviación } \\
\text { típica }\end{array}$} & \multirow{2}{*}{$\begin{array}{l}\text { Error } \\
\text { típico }\end{array}$} & \multicolumn{2}{|c|}{$\begin{array}{l}\text { Intervalo de confianza } \\
\text { para la media } 95 \%\end{array}$} & \multirow{2}{*}{ Mínimo } & \multirow{2}{*}{ Máximo } \\
\hline & & & & & $\begin{array}{l}\text { Límite } \\
\text { inferior }\end{array}$ & $\begin{array}{l}\text { Límite } \\
\text { superior }\end{array}$ & & \\
\hline Años fumando & 151 & 44,50 & 10,666 &, 868 & 42,79 & 46,22 & 20 & 70 \\
\hline Edad empieza & 151 & 17,69 & 3,896 & 317 & 17,06 & 18,32 & 11 & 45 \\
\hline
\end{tabular}

- De igual manera, cuanto más viejo se deja de fumar, más años se fuma.

Tabla 34. Edad de finalización del hábito tabáquico y número de años fumados

\begin{tabular}{|c|c|c|c|c|c|c|c|c|}
\hline & \multirow{2}{*}{$N$} & \multirow{2}{*}{ Media } & \multirow{2}{*}{$\begin{array}{c}\text { Desviación } \\
\text { típica }\end{array}$} & \multirow{2}{*}{$\begin{array}{l}\text { Error } \\
\text { típico }\end{array}$} & \multicolumn{2}{|c|}{$\begin{array}{l}\text { Intervalo de confianza } \\
\text { para la media al } 95 \%\end{array}$} & \multirow{2}{*}{ Mínimo } & \multirow{2}{*}{ Máximo } \\
\hline & & & & & $\begin{array}{l}\text { Límite } \\
\text { inferior }\end{array}$ & $\begin{array}{c}\text { Límite } \\
\text { superior }\end{array}$ & & \\
\hline Años fumando & 151 & 44,50 & 10,666 &, 868 & 42,79 & 46,22 & 20 & 70 \\
\hline Edad lo deja & 151 & 62,03 & 9,939 & ,809 & 60,43 & 63,63 & 35 & 85 \\
\hline
\end{tabular}


- La correlación entre las dos variables es positiva y muy significativa. Gráficamente:

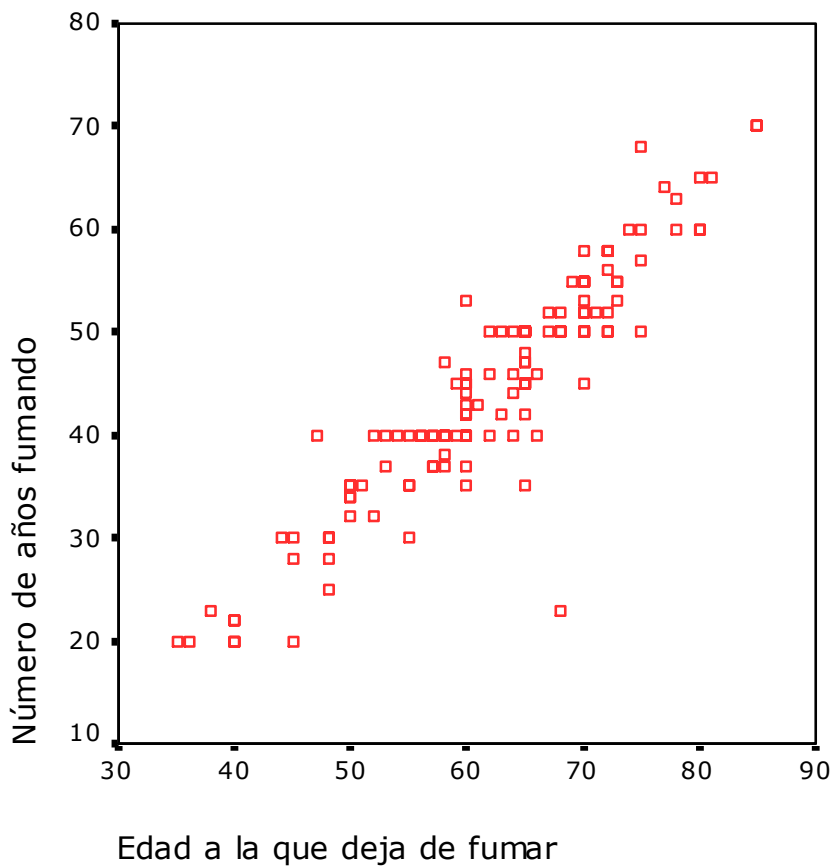

\subsection{2.- CONTROLES DE MENOS DE 65 AÑOS}

En este grupo se han recogido menos variables.

\section{Sexo}

- De media los varones fuman más paquetes de tabaco al día.

Tabla 35. Media de paquetes/día en el grupo control menor de 65 años según el sexo

\begin{tabular}{|c|c|c|c|c|c|c|c|c|}
\hline & \multirow{2}{*}{$N$} & \multirow{2}{*}{ Media } & \multirow{2}{*}{$\begin{array}{c}\text { Desviación } \\
\text { típica }\end{array}$} & \multirow{2}{*}{$\begin{array}{l}\text { Error } \\
\text { típico }\end{array}$} & \multicolumn{2}{|c|}{$\begin{array}{l}\text { Intervalo de confianza } \\
\text { para la media al } 95 \%\end{array}$} & \multirow{2}{*}{ Mínimo } & \multirow{2}{*}{ Máximo } \\
\hline & & & & & $\begin{array}{l}\text { Límite } \\
\text { inferior }\end{array}$ & $\begin{array}{l}\text { Límite } \\
\text { superior }\end{array}$ & & \\
\hline$\overline{\text { Varón }}$ & 78 & 1,417 &, 6352 & 0719 & 1,273 & 1,560 &, 2 & 4,0 \\
\hline Mujer & 75 & 1,163 & ,5255 & ,0607 & 1,042 & 1,284 & ,3 & 3,5 \\
\hline Total & 153 & 1,292 & ,5959 & ,0482 & 1,197 & 1,387 &, 2 & 4,0 \\
\hline
\end{tabular}




\section{II.- Edad}

- A mayor edad más años fumando.

Tabla 36. Media de la edad y del número de años fumando del grupo control menor de 65 años

\begin{tabular}{|c|c|c|c|c|c|c|c|c|}
\hline & \multirow{2}{*}{$N^{o}$} & \multirow{2}{*}{ Media } & \multirow{2}{*}{$\begin{array}{c}\text { Desviación } \\
\text { típica }\end{array}$} & \multirow{2}{*}{$\begin{array}{l}\text { Error } \\
\text { típico }\end{array}$} & \multicolumn{2}{|c|}{$\begin{array}{l}\text { Intervalo de confianza } \\
\text { para la media al } 95 \%\end{array}$} & \multirow{2}{*}{ Mínimo } & \multirow{2}{*}{ Máximo } \\
\hline & & & & & $\begin{array}{l}\text { Límite } \\
\text { inferior }\end{array}$ & $\begin{array}{l}\text { Límite } \\
\text { superior }\end{array}$ & & \\
\hline Edad & 153 & 42,27 & 9,483 &, 767 & 40,75 & 43,78 & 16 & 64 \\
\hline Años fumando & 153 & 19,98 & 9,690 & ,783 & 18,43 & 21,53 & 1 & 55 \\
\hline
\end{tabular}

- La correlación entre las dos variables es positiva y muy significativa.

Gráficamente:

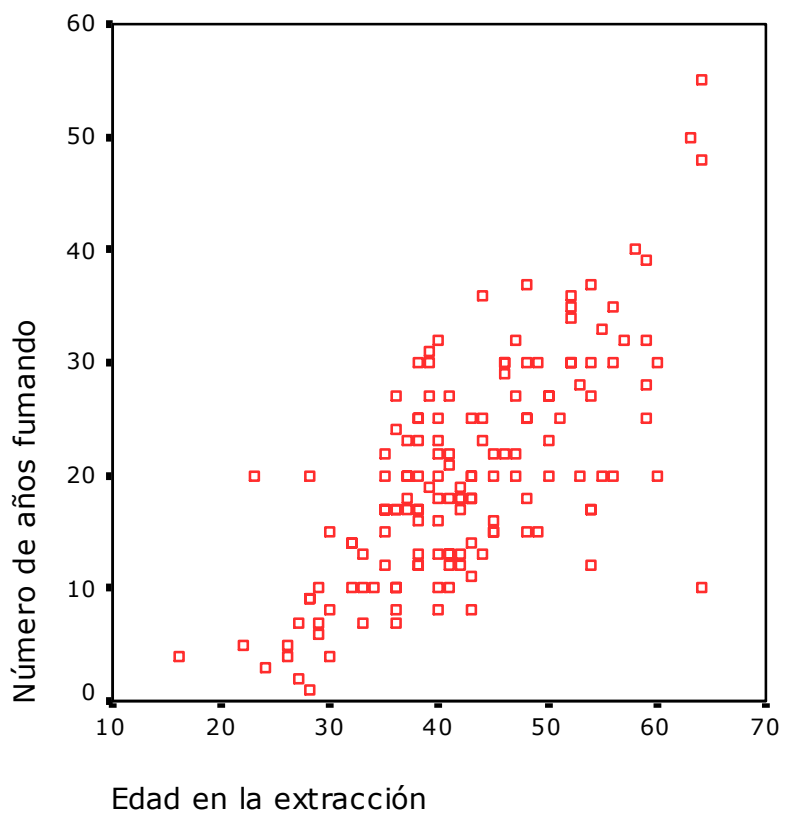




\subsection{3.- DIFERENCIAS ENTRE LAS DOS MUESTRAS CONTROL}

La única diferencia que se ha encontrado es en el número de años fumando, de forma que de media, este número es significativamente mayor en la muestra de individuos con 65 años o más. Por otro lado es lógico, puesto que esta variable está muy relacionada con la edad y la edad es la que clasifica a cada paciente en cada muestra.

Tabla 37. Media del número de años fumando según el grupo control

\begin{tabular}{|c|c|c|c|c|c|c|c|c|}
\hline & \multirow{2}{*}{$N^{o}$} & \multirow{2}{*}{ Media } & \multirow{2}{*}{$\begin{array}{c}\text { Desviación } \\
\text { típica }\end{array}$} & \multirow{2}{*}{$\begin{array}{l}\text { Error } \\
\text { típico }\end{array}$} & \multicolumn{2}{|c|}{$\begin{array}{c}\text { Intervalo de confianza } \\
\text { para la media } 95 \%\end{array}$} & \multirow{2}{*}{ Mínimo } & \multirow{2}{*}{ Máximo } \\
\hline & & & & & $\begin{array}{l}\text { Límite } \\
\text { inferior }\end{array}$ & $\begin{array}{c}\text { Límite } \\
\text { superior }\end{array}$ & & \\
\hline$>=65$ años & 151 & 44,50 & 10,666 &, 868 & 42,79 & 46,22 & 20 & 70 \\
\hline$<65$ años & 153 & 19,98 & 9,690 &, 783 & 18,43 & 21,53 & 1 & 55 \\
\hline Total & 304 & 32,16 & 15,945 & ,915 & 30,36 & 33,96 & 1 & 70 \\
\hline
\end{tabular}

\subsection{4.- DIFERENCIAS ENTRE CASOS Y CONTROLES}

\section{I.- Sexo.}

- Hay más mujeres en los controles: el $9,40 \%$ de los casos son mujeres frente al $24,67 \%$ de los controles.

\section{II.- Número de paquetes al día.}

- De media los casos de cáncer de pulmón fuman significativamente más paquetes de tabaco al día que los controles. Esta diferencia es de 0,2 paquetes aproximadamente. 
Tabla 38. Media del número de paquetes/día en el grupo de casos y de controles

\begin{tabular}{|c|c|c|c|c|c|c|c|c|}
\hline & \multirow{2}{*}{$N^{o}$} & \multirow{2}{*}{ Media } & \multirow{2}{*}{$\begin{array}{c}\text { Desviación } \\
\text { típica }\end{array}$} & \multirow{2}{*}{$\begin{array}{l}\text { Error } \\
\text { típico }\end{array}$} & \multicolumn{2}{|c|}{$\begin{array}{c}\text { Intervalo de confianza } \\
\text { para la media } 95 \%\end{array}$} & \multirow{2}{*}{ Mínimo } & \multirow{2}{*}{ Máximo } \\
\hline & & & & & $\begin{array}{l}\text { Límite } \\
\text { inferior }\end{array}$ & $\begin{array}{l}\text { Límite } \\
\text { superior }\end{array}$ & & \\
\hline Caso & 134 & 1,561 & 6179 & 0534 & 1,456 & 1,667 &, 2 & 3,0 \\
\hline Control & 304 & 1,327 & , 5770 & 0331 & 1,262 & 1,392 &, 2 & 4,0 \\
\hline Total & 438 & 1,399 & ,5989 &, 0286 & 1,343 & 1,455 &, 2 & 4,0 \\
\hline
\end{tabular}

\section{III.- Número de años fumando.}

- De media los casos de cáncer de pulmón fuman significativamente más años que los controles. Esta diferencia es de 6 años aproximadamente. Esta diferencia puede estar algo distorsionada por la variable edad, puesto que la diferencia en las edades de los dos grupos son aproximadamente 5 años y se ha comprobado que existe una relación entre las variables edad y el número de años que se lleva fumando.

Tabla 39. Media del número de años fumando en el grupo de casos y de controles

\begin{tabular}{|c|c|c|c|c|c|c|c|c|}
\hline & \multirow{2}{*}{$N^{o}$} & \multirow{2}{*}{ Media } & \multirow{2}{*}{$\begin{array}{c}\text { Desviación } \\
\text { típica }\end{array}$} & \multirow{2}{*}{$\begin{array}{l}\text { Error } \\
\text { típico }\end{array}$} & \multicolumn{2}{|c|}{$\begin{array}{l}\text { Intervalo de confianza } \\
\text { para la media al } 95 \%\end{array}$} & \multirow{2}{*}{ Mínimo } & \multirow{2}{*}{ Máximo } \\
\hline & & & & & $\begin{array}{c}\text { Límite } \\
\text { inferior }\end{array}$ & $\begin{array}{c}\text { Límite } \\
\text { superior }\end{array}$ & & \\
\hline Caso & 132 & 38,10 & 10,532 & ,917 & 36,29 & 39,91 & 10 & 64 \\
\hline Control & 304 & 32,16 & 15,945 & 915 & 30,36 & 33,96 & 1 & 70 \\
\hline Total & 436 & 33,96 & 14,764 & ,707 & 32,57 & 35,35 & 1 & 70 \\
\hline
\end{tabular}




\section{3.- INFLUENCIA DE LOS FACTORES DE RIESGO EN EL DESARROLLO DEL CÁNCER DE PULMÓN}

Ajustamos un modelo de regresión logística en cada grupo (Grupo con 65 años o más, Grupo con menos de 65 años y en general). La razón es simplemente que no tenemos todos los factores de riesgo en todos los casos.

\subsection{1.- MODELO GENERAL}

Se incluyen los pacientes fumadores, puesto que en el grupo control sólo hay fumadores.

Las variables que se utilizan para explicar el hecho de que un paciente desarrolle o no cáncer de pulmón son: Sexo, Edad, Número de paquetes que se fuman al día y Número de años fumando.

Tabla 40. Porcentaje del número de casos estudiados

\begin{tabular}{||c|c|c|}
\cline { 2 - 3 } \multicolumn{1}{c|}{} & $\boldsymbol{N}$ & Porcentaje \\
\hline Incluidos en el análisis & 434 & 98,6 \\
\hline Casos perdidos & 6 & 1,4 \\
\hline Total & 440 & 100,0 \\
\hline
\end{tabular}

\section{I.- Modelo ajustado}

Tabla 41. Variables incluidas en la ecuación

\begin{tabular}{|c|c|c|c|c|c|c|c|c||}
\hline \multirow{2}{*}{} & \multirow{2}{*}{$\boldsymbol{B}$} & \multirow{2}{*}{ E.T. } & \multirow{2}{*}{ Wald } & \multirow{2}{*}{$\boldsymbol{g l}$} & \multirow{2}{*}{ Sig. } & \multirow{2}{*}{$\operatorname{Exp(B)}$} & \multicolumn{2}{|c|}{ I.C. 95,0\% para EXP(B) } \\
\cline { 7 - 10 } & & & & & & & Inferior & Superior \\
\hline Edad &,- 031 &, 012 & 6,914 & 1 &, 009 &, 969 &, 947 &, 992 \\
\hline Sexo & 2,253 &, 555 & 16,480 & 1 &, 000 & 9,518 & 3,207 & 28,247 \\
\hline Paq./dia &, 585 &, 184 & 10,166 & 1 &, 001 & 1,795 & 1,253 & 2,573 \\
\hline N.años &, 040 &, 013 & 9,241 & 1 &, 002 & 1,041 & 1,014 & 1,068 \\
\hline Constante & $-3,179$ &, 663 & 22,977 & 1 &, 000 &, 042 & & \\
\hline
\end{tabular}

Estudio de los polimorfismos de genes reparadores en población fumadora con y sin cáncer de pulmón 
Se llega a este modelo en un único paso, es decir que nos quedamos con el modelo en el que participan todas las variables independientes.

\section{II.- Interpretación del modelo.}

Utilizamos las estimaciones de las odds ratio $(\exp (\mathrm{B}))$ :

- Edad. A medida que cumplimos años disminuye el riesgo de paceder cáncer de pulmón (O.R. 0,969). Este efecto es significativo.

- $\underline{\text { Sexo }}$. El riesgo de paceder cáncer de pulmón es mayor entre varones que entre mujeres (O.R. 9,518). Este efecto es significativo.

- Número de paquetes fumados al día. A medida que aumenta el número de paquetes de tabaco que se fuman al día aumenta el riesgo de padecer cáncer de pulmón (O.R. 1,795). Este efecto es significativo.

- Número de años fumando. A medida que aumenta el número de años que se lleva fumando, aumenta el riesgo de padecer cáncer de pulmón (O.R. 1,041). Este efecto es significativo

\section{III.- Contrastes de bondad de ajuste}

Para saber si el modelo que planteamos describe adecuadamente a los datos utilizamos el contraste de Hosmer-Lemeshow. La hipótesis que se contrasta es si el modelo explica bien los datos observados.

Tabla 42.

\begin{tabular}{|c|c|c|c||}
\hline Paso & Chi-cuadrado & $\boldsymbol{g l}$ & Sig. \\
\hline 1 & 7,832 & 8 &, 450 \\
\hline
\end{tabular}

No se rechaza la hipótesis nula, por tanto podemos suponer que el modelo es bueno para explicar nuestros datos. 


\section{IV.- Validación interna}

Curva ROC. Presentamos el área bajo la curva ROC como un índice de la capacidad de predecir el cáncer que tiene el modelo. Este área está entre 0,5 (el modelo es muy mal predictor) y 1 (el modelo perfecto). También se presenta un contraste de hipótesis que contrasta si este índice puede considerarse 0,5 .

Tabla 43.

\begin{tabular}{||c|c|c|c|c||}
\hline \multirow{2}{*}{ Área } & \multirow{2}{*}{ Error típ. } & \multirow{2}{*}{$\begin{array}{c}\text { Sig. } \\
\text { asintótica }\end{array}$} & \multicolumn{2}{|c|}{ Intervalo de confianza asintótico al 95\% } \\
\cline { 4 - 5 } & & & Límite inferior & Límite superior \\
\hline \hline, 712 &, 026 &, 000 &, 661 &, 762 \\
\hline
\end{tabular}

Rechazamos la hipótesis nula, es decir que podemos considerar que el área bajo la curva es significativamente distinta de 0,5 y por tanto nuestro modelo puede considerarse bueno. Gráficamente,

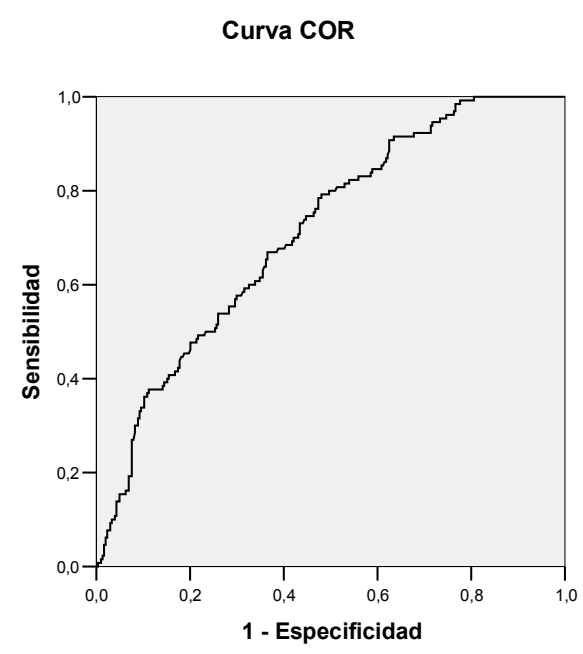

Los segmentos diagonales son producidos por los empates.

También utilizamos la tabla de clasificación. Es una tabla de contingencia entre los valores observados y los valores pronosticados por el modelo. Nos dan los valores de sensibilidad y especificidad del modelo ajustado. 
Tabla 44.

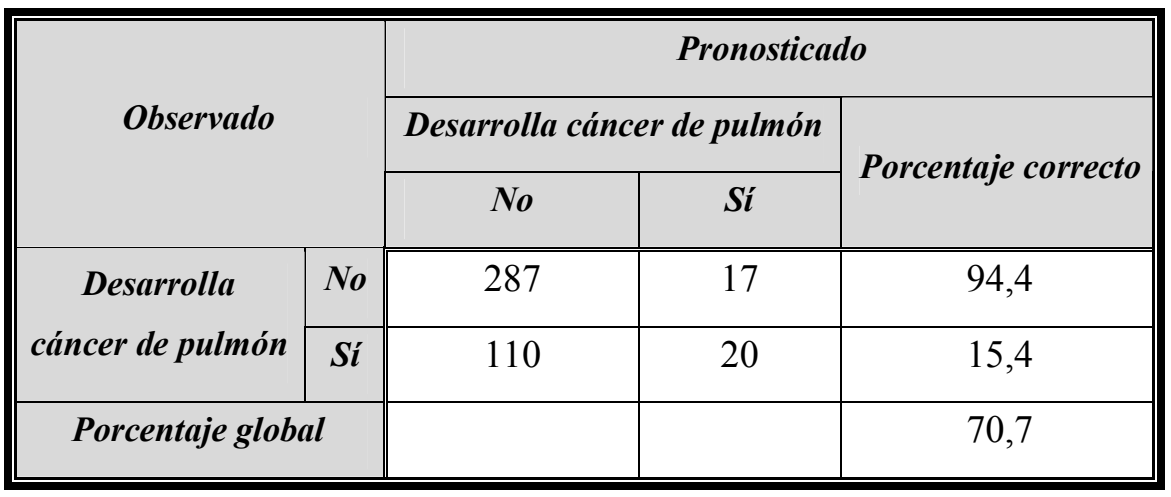

El modelo clasifica correctamente prácticamente al 71\% de los pacientes. A partir de esta tabla obtenemos,

- Sensibilidad, proporción de verdaderos positivos identificados entre el total de enfermos, $15,4 \%$. Este valor es bastante malo.

- Especificidad, proporción de verdaderos negativos identificados entre el total de sanos, $94,4 \%$.

Los factores significativos son las variables sexo, edad, número de paquetes de tabaco que se fuman al día y número de años fumando. El riesgo de padecer cáncer de pulmón aumenta con la edad, con el número de cigarrillos fumados y con el tiempo que se lleva fumando. Además es más probable tener cáncer entre los varones.

\subsection{2.- MODELO PARA MENORES DE 65 AÑOS}

Se incluyen los pacientes menores de 65 años y fumadores, puesto que en el grupo control sólo hay fumadores.

Las variables que se utilizan para explicar el hecho de que un paciente desarrolle o no cáncer de pulmón son: Sexo, Edad, Número de paquetes que se fuman al día y Número de años fumando. 
Tabla 45. Porcentaje del número de casos estudiados

\begin{tabular}{|c|c|c||}
\cline { 2 - 3 } \multicolumn{1}{c|}{} & $N^{\boldsymbol{0}}$ & Porcentaje \\
\hline Incluidos en el análisis & 217 & 98,6 \\
\hline Casos perdidos & 3 & 1,4 \\
\hline Total & 220 & 100,0 \\
\hline
\end{tabular}

\section{I.- Codificación de variables}

Tabla 46. Variable dependiente: el paciente desarrolla cáncer de pulmón

\begin{tabular}{|c|c|}
\hline Valor original & Valor interno \\
\hline \hline No & 0 \\
\hline Sí & 1 \\
\hline
\end{tabular}

Tabla 47. Variables independientes categóricas

\begin{tabular}{|c|c|c|c|}
\hline & & Frecuencia & $\begin{array}{c}\text { Codificación de parámetros } \\
\text { (1) }\end{array}$ \\
\hline \multirow{2}{*}{ Sexo } & Varón & 138 & 1,000 \\
\hline & Mujer & 79 &, 000 \\
\hline
\end{tabular}




\section{II.- Modelo ajustado}

Tabla 48. Variables incluidas en la ecuación

\begin{tabular}{|c|c|c|c|c|c|c|c|c|}
\hline & \multirow{2}{*}{$B$} & \multirow{2}{*}{ E.T. } & \multirow{2}{*}{ Wald } & \multirow{2}{*}{$g l$} & \multirow{2}{*}{ Sig. } & \multirow{2}{*}{$\operatorname{Exp}(B)$} & \multicolumn{2}{|c|}{ I.C. 95,0\% para EXP(B) } \\
\hline & & & & & & & Inferior & Superior \\
\hline Edad &, 063 &, 033 & 3,568 & 1 &, 059 & 1,065 & ,998 & 1,136 \\
\hline Sexo & 1,904 &, 584 & 10,632 & 1 & ,001 & 6,714 & 2,137 & 21,091 \\
\hline Paq./día &, 859 &, 317 & 7,342 & 1 &, 007 & 2,362 & 1,268 & 4,397 \\
\hline$N^{o}$ años & ,095 &, 031 & 9,528 & 1 & ,002 & 1,100 & 1,035 & 1,168 \\
\hline Constante & $-9,180$ & 1,463 & 39,357 & 1 &, 000 & ,000 & & \\
\hline
\end{tabular}

Se llega a este modelo en un único paso, es decir que nos quedamos con el modelo en el que participan todas las variables independientes.

\section{III.- Interpretación del modelo}

Utilizamos las estimaciones de las odds ratio $(\exp (B))$ :

- Edad. A medida que cumplimos años aumenta el riesgo de paceder cáncer de pulmón (O.R. 1,065). Este valor no es significativamente distinto de $1(\mathrm{p}$-valor $=0,059)$ por tanto no es una variable muy influyente.

- $\underline{S e x o}$. El riesgo de paceder cáncer de pulmón es mayor entre varones que entre mujeres (O.R. 6,714). Este efecto es significativo.

- Número de paquetes fumados al día. A medida que aumenta el número de paquetes de tabaco que se fuman al día aumenta el riesgo de padecer cáncer de pulmón (O.R. 2,362). Este efecto es significativo.

- Número de años fumando. A medida que aumenta el número de años que se lleva fumando, aumenta el riesgo de padecer cáncer de pulmón (O.R. 1,100). Este efecto es significativo. 


\section{IV.- Contraste de bondad de ajuste}

Tabla 49. Contraste de Hosmer-Lemeshow,

\begin{tabular}{|c|c|c|c|}
\hline Paso & Chi-cuadrado & gl & Sig. \\
\hline \hline 1 & 3,371 & 8 &, 909 \\
\hline
\end{tabular}

No se rechaza la hipótesis nula, por tanto podemos suponer que el modelo es bueno para explicar nuestros datos.

\section{V.- Validación interna}

Utilizamos el Área bajo la curva ROC

Tabla 50. Área bajo la curva ROC

\begin{tabular}{|c|c|c|c|c|}
\hline \multirow{2}{*}{ Área } & \multirow{2}{*}{ Error típ. } & \multirow{2}{*}{ Sig. asintótica } & \multicolumn{2}{|c|}{ Intervalo de confianza asintótico al 95\% } \\
\cline { 4 - 5 } & & & Límite inferior & Límite superior \\
\hline \hline, 895 &, 022 &, 000 &, 852 &, 938 \\
\hline
\end{tabular}

Rechazamos la hipótesis nula, es decir que podemos considerar que el área bajo la curva es significativamente distinta de 0,5 y por tanto nuestro modelo puede considerarse bueno.

Gráficamente:

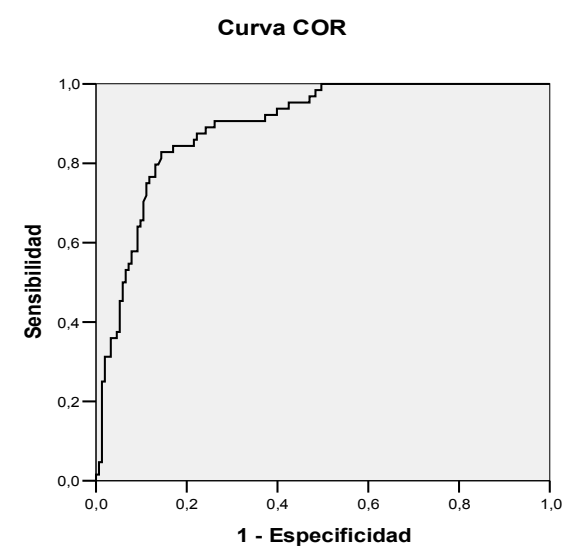

Los segmentos diagonales son producidos por los empates. 
Tabla 51. Tabla de clasificación

\begin{tabular}{|c|c|c|c|c|}
\hline \multirow{3}{*}{ Observado } & & \multicolumn{3}{|c|}{ Pronosticado } \\
\hline & & \multicolumn{2}{|c|}{ Desarrolla cáncer de pulmón } & \multirow{2}{*}{ Porcentaje correcto } \\
\hline & & No & Sí & \\
\hline \multirow{2}{*}{ Desarrolla cáncer de pulmón } & No & 137 & 16 & 89,5 \\
\hline & Sí & 19 & 45 & 70,3 \\
\hline \multicolumn{2}{|l|}{ Porcentaje global } & & & 83,9 \\
\hline
\end{tabular}

El modelo clasifica correctamente prácticamente al $84 \%$ de los pacientes. A partir de esta tabla obtenemos,

- Sensibilidad, $70,3 \%$

- Especificidad, $89,5 \%$

Los factores significativos son las variables sexo, número de paquetes de tabaco que se fuman al día y número de años fumando. El riesgo de padecer cáncer de pulmón aumenta con el número de cigarrillos fumados y con el tiempo que se lleva fumando. Además es más probable tener cáncer entre los varones.

\subsection{3.- MODELO PARA 65 AÑOS O MÁS}

Se incluyen los pacientes con 65 años o más y fumadores, puesto que en el grupo control sólo hay fumadores.

Las variables que se utilizan para explicar el hecho de que un paciente desarrolle o no cáncer de pulmón son: sexo, edad, lugar de residencia, tipo de profesión, antecedentes de EPOC, antecedentes familiares oncológicos, tipo de tabaco que fuma, número de paquetes que se fuman al día, número de años fumando, edad a la que se comienza a fumar y edad a la que se deja de fumar. 
Tabla 52. Porcentaje del número de casos estudiados

\begin{tabular}{|c|c|c|}
\cline { 2 - 3 } \multicolumn{1}{c|}{} & $N^{\boldsymbol{o}}$ & Porcentaje \\
\hline Incluidos en el análisis & 211 & 96,8 \\
\hline Casos perdidos & 7 & 3,2 \\
\hline Total & 218 & 100,0 \\
\hline
\end{tabular}

\section{I.- Codificación de variables}

Tabla 53. Variable dependiente: el paciente desarrolla cáncer de pulmón

\begin{tabular}{|c|c|}
\hline Valor original & Valor interno \\
\hline \hline No & 0 \\
\hline Sí & 1 \\
\hline
\end{tabular}

Tabla 54. Variables independientes categóricas

\begin{tabular}{|c|c|c|c|c|}
\hline & & \multirow{2}{*}{ Frecuencia } & \multicolumn{2}{|c|}{ Codificación de parámetros } \\
\hline & & & (1) & (2) \\
\hline \multirow{3}{*}{ Tipo de tabaco que fuma } & Negro & 182 & 1,000 &, 000 \\
\hline & Rubio & 22 &, 000 & 1,000 \\
\hline & Negro y Rubio & 7 &, 000 & ,000 \\
\hline \multirow{2}{*}{ Tipo de profesión } & Riesgo & 34 & 1,000 & \\
\hline & No riesgo & 177 &, 000 & \\
\hline \multirow{2}{*}{ Antecedentes de EPOC } & Sí & 62 & 1,000 & \\
\hline & No & 149 &, 000 & \\
\hline \multirow{2}{*}{ Antecedentes familiares oncológicos } & Sí & 79 & 1,000 & \\
\hline & No & 132 &, 000 & \\
\hline \multirow{2}{*}{ Lugar de residencia } & Urbano & 77 & 1,000 & \\
\hline & Rural & 134 &, 000 & \\
\hline
\end{tabular}


Se ha eliminado la variable sexo porque todos los sujetos son hombres.

\section{II.- Modelo ajustado}

Tabla 55. Variables incluidas en la ecuación

\begin{tabular}{|c|c|c|c|c|c|c|c|c|}
\hline & \multirow{2}{*}{$B$} & \multirow{2}{*}{ E.T. } & \multirow{2}{*}{ Wald } & \multirow{2}{*}{$g l$} & \multirow{2}{*}{ Sig. } & \multirow{2}{*}{$\operatorname{Exp}(B)$} & \multicolumn{2}{|c|}{ I.C. $95,0 \%$ para $E X P(B)$} \\
\hline & & & & & & & Inferior & Superior \\
\hline Edad &,- 142 & ,032 & 19,000 & 1 &, 000 & ,868 & 815 & ,925 \\
\hline N.años &,- 093 & ,041 & 5,227 & 1 &, 022 & 911 & 842 & ,987 \\
\hline Edad deja & ,104 & 043 & 5,973 & 1 & 015 & 1,110 & 1,021 & 1,206 \\
\hline Constante & 7,144 & 2,479 & 8,300 & 1 &, 004 & 1265,917 & & \\
\hline
\end{tabular}

Se llega a este modelo en 8 pasos. El orden en el que van saliendo las variables es el siguiente:

Tabla 56

\begin{tabular}{|c|l||}
\hline Paso & \multicolumn{1}{c|}{ Variable que sale } \\
\hline \hline 1 & Tipo de residencia (rural vs urbano) \\
\hline 2 & Tipo de profesión (riesgo vs no riesgo) \\
\hline 3 & Antecedentes familiares oncológicos (Sí vs No) \\
\hline 4 & Tipo de tabaco que fuma (rubio vs negro vs rubio y negro) \\
\hline 5 & Antecedentes de EPOC (Sí vs No) \\
\hline 6 & Edad a la que empieza a fumar \\
\hline 7 & Número de paquetes que fuma al día \\
\hline
\end{tabular}

\section{III.- Interpretación del modelo}

Utilizamos las estimaciones de las odds ratio $(\exp (\mathrm{B}))$ : 
- Edad. A medida que cumplimos años disminuye el riesgo de paceder cáncer de pulmón (O.R. 0,868). Este efecto es significativo.

- Número de años fumando. A medida que aumenta el número de años que se lleva fumando, disminuye el riesgo de padecer cáncer de pulmón (O.R. 0,911). Este efecto es significativo.

- Edad a la que deja de fumar. A medida que aumenta la edad a la que se deja de fumar, aumenta el riesgo de padecer cáncer de pulmón (O.R. 1,11). Este efecto es significativo

\section{IV.- Contrastes de bondad de ajuste}

Tabla 57. Contraste de Hosmer-Lemeshow

\begin{tabular}{|c|c|c|c|}
\hline Paso & Chi-cuadrado & gl & Sig. \\
\hline \hline 1 & 4,693 & 8 &, 790 \\
\hline
\end{tabular}

No se rechaza la hipótesis nula, por tanto podemos suponer que el modelo es bueno para explicar nuestros datos.

\section{V.- Validación interna}

Tabla 58. Área bajo la curva ROC

\begin{tabular}{|c|c|c|c|c|}
\hline \multirow{2}{*}{ Área } & \multirow{2}{*}{ Error típ. } & \multirow{2}{*}{ Sig. asintótica } & \multicolumn{2}{|c|}{ Intervalo de confianza asintótico al 95\% } \\
\cline { 4 - 5 } & & & Límite inferior & Límite superior \\
\hline \hline, 738 &, 036 &, 000 &, 667 &, 810 \\
\hline
\end{tabular}

Rechazamos la hipótesis nula, es decir que podemos considerar que el área bajo la curva es significativamente distinta de 0,5 y por tanto nuestro modelo puede considerarse bueno. 
Gráficamente:

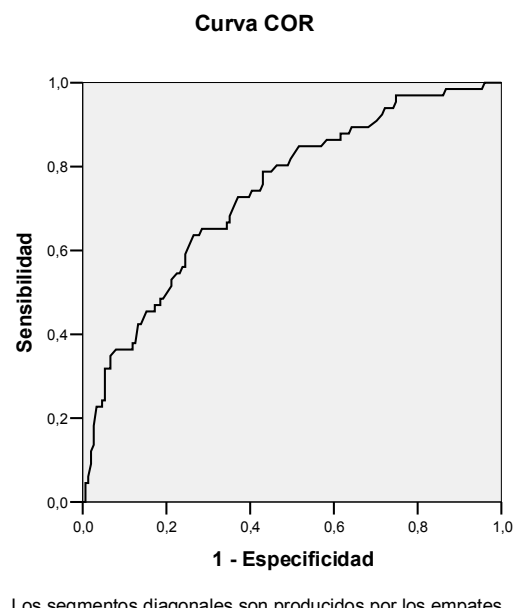

Tabla 59. Tabla de clasificación

\begin{tabular}{|c|c|c|c|c|}
\hline \multirow{3}{*}{\multicolumn{2}{|c|}{ Observado }} & \multicolumn{3}{|c|}{ Pronosticado } \\
\hline & & \multicolumn{2}{|c|}{ Desarrolla cáncer de pulmón } & \multirow{2}{*}{ Porcentaje correcto } \\
\hline & & No & Sí & \\
\hline \multirow{2}{*}{ Desarrolla cáncer de pulmón } & No & 145 & 6 & 96,0 \\
\hline & Sí & 42 & 18 & 30,0 \\
\hline \multicolumn{2}{|l|}{ Porcentaje global } & & & \\
\hline
\end{tabular}

El modelo clasifica correctamente prácticamente al $77 \%$ de los pacientes. A partir de esta tabla obtenemos,

- Sensibilidad, $30,0 \%$

- Especificidad, 96,0\%

Los factores significativos son las variables edad, número de años fumando y la edad a la que deja de fumar. En este grupo, el riesgo de padecer cáncer de pulmón disminuye con la edad y con el número de años fumando. El riesgo aumenta con la edad a la que se deja de fumar. 


\section{2.- ANALISIS DE LAS VARIABLES GENETICAS}

\section{1.- ANÁLISIS PRELIMINAR. EQUILIBRIO DE HARDY WEINBERG}

La ley de equilibrio de Hardy y Weinberg es un modelo que predice la relación que debe existir entre frecuencias alélicas y frecuencias genotípicas en una población de características ideales que cumple una serie de supuestos.

Se comprueba esta hipótesis en los distintos grupos de pacientes para los distintos polimorfismos que se pretende analizar.

\subsection{1.- CONTROLES CON 65 AÑOS O MÁS}

\section{I.- Polimorfismo ERCC1}

Tabla 60. Equilibrio de Hardy-Weinberg

\begin{tabular}{|c|c|c|}
\hline Estadístico & gl & Sig. \\
\hline \hline 0,2475 & 1 & 0,6188 \\
\hline
\end{tabular}

No se rechaza la hipótesis de equilibrio.

\section{II- Polimorfismo XRCC1}

Tabla 61. Equilibrio de Hardy-Weinberg

\begin{tabular}{|c|c|c|}
\hline Estadístico & gl & Sig. \\
\hline \hline 0,3479 & 1 & 0,5553 \\
\hline
\end{tabular}

No se rechaza la hipótesis de equilibrio.

\section{III- Polimorfismo P53 Exón 4}

En este polimorfismo no se cumple el Equilibrio de Hardy-Weinberg. 
Tabla 62. Tabla de frecuencias

\begin{tabular}{|c|c|c|c|c|c|}
\hline & & Frecuencia & Porcentaje & $\begin{array}{c}\text { Porcentaje } \\
\text { válido }\end{array}$ & $\begin{array}{l}\text { Porcentaje } \\
\text { acumulado }\end{array}$ \\
\hline \multirow{4}{*}{ Válidos } & Arg/Arg & 90 & 59,6 & 59,6 & 59,6 \\
\hline & Pro/Pro & 15 & 9,9 & 9,9 & 69,5 \\
\hline & Arg/Pro & 46 & 30,5 & 30,5 & 100,0 \\
\hline & Total & 151 & 100,0 & 100,0 & \\
\hline \multicolumn{2}{|c|}{ Perdidos } & 0 & , 0 & & \\
\hline \multicolumn{2}{|c|}{ Total } & 151 & 100,0 & & \\
\hline
\end{tabular}

Tabla 63. Frecuencias alélicas

\begin{tabular}{|c|c|c|}
\hline Alelo & Frecuencia absoluta & Frecuencia relativa \\
\hline \multirow{2}{*}{ Arg } & 113 & 0,7483 \\
\hline \multirow{2}{*}{ Pro } & 38 & 0,2517 \\
\hline
\end{tabular}

Tabla 64. Frecuencias genotípicas

\begin{tabular}{||c|c|c|c|c|}
\hline \multirow{2}{*}{ Genotipo } & \multicolumn{2}{|c|}{ Frecuencia observada } & \multicolumn{2}{c|}{ Frecuencia esperada } \\
\cline { 2 - 5 } & Absoluta & Relativa & Absoluta & Relativa \\
\hline ArgArg & 90 & 0,5960 & 85 & 0,5600 \\
\hline ProPro & 15 & 0,0993 & 10 & 0,0633 \\
\hline ArgPro & 46 & 0,3046 & 57 & 0,3767 \\
\hline
\end{tabular}

Tabla 65. Equilibrio de Hardy-Weinberg

\begin{tabular}{|c|c|c|}
\hline Estadístico & gl & Sig. \\
\hline \hline 5,5200 & 1 & 0,0188 \\
\hline
\end{tabular}

Se rechaza la hipótesis de equilibrio. 


\section{IV.- Polimorfismo P53 Intron 3}

Tabla 66. Equilibrio de Hardy-Weinberg

\begin{tabular}{|c|c|c|}
\hline Estadístico & gl & Sig. \\
\hline \hline 1,5877 & 1 & 0,2077 \\
\hline
\end{tabular}

No se rechaza la hipótesis de equilibrio.

\subsection{2.- CONTROLES CON MENOS DE 65 AÑOS}

\section{I.- Polimorfismo P53 Exón 4}

Tabla 67. Equilibrio de Hardy-Weinberg,

\begin{tabular}{|c|c|c|}
\hline Estadístico & $\boldsymbol{g l}$ & Sig. \\
\hline \hline 0,1613 & 1 & 0,6880 \\
\hline
\end{tabular}

No se rechaza la hipótesis de equilibrio.

\section{II.- Polimorfismo P53 Intron 3}

En este polimorfismo no se cumple el Equilibrio de Hardy-Weinberg.

Tabla 68. Tabla de frecuencias

\begin{tabular}{|c|c|c|c|c|c|}
\hline & & Frecuencia & Porcentaje & $\begin{array}{c}\text { Porcentaje } \\
\text { válido }\end{array}$ & $\begin{array}{l}\text { Porcentaje } \\
\text { acumulado }\end{array}$ \\
\hline \multirow{4}{*}{ Válidos } & $106 b p$ & 11 & 7,1 & 7,1 & 7,1 \\
\hline & $90 b p$ & 104 & 67,1 & 67,1 & 74,2 \\
\hline & $106+90 b p$ & 40 & 25,8 & 25,8 & 100,0 \\
\hline & Total & 155 & 100,0 & 100,0 & \\
\hline \multicolumn{2}{|c|}{ Perdidos } & 0 &, 0 & & \\
\hline \multicolumn{2}{|c|}{ Total } & 151 & 100,0 & & \\
\hline
\end{tabular}


Tabla 69. Frecuencias alélicas

\begin{tabular}{|c|c|c|}
\hline Alelo & Frecuencia absoluta & Frecuencia relativa \\
\hline \hline $106 \mathrm{bp}$ & 31 & 0,2000 \\
\hline $90 \mathrm{bp}$ & 124 & 0,8000 \\
\hline
\end{tabular}

Tabla 70. Frecuencias genotípicas

\begin{tabular}{|c|c|c|c|c|}
\hline \multirow{2}{*}{ Genotipo } & \multicolumn{2}{|c|}{ Frecuencia observada } & \multicolumn{2}{c|}{ Frecuencia esperada } \\
\cline { 2 - 5 } & Absoluta & Relativa & Absoluta & Relativa \\
\hline \hline $106 \mathrm{bp}$ & 11 & 0,0710 & 6 & 0,0400 \\
\hline $90 \mathrm{bp}$ & 104 & 0,6710 & 99 & 0,6400 \\
\hline $106+90 \mathrm{bp}$ & 40 & 0,2581 & 50 & 0,3200 \\
\hline
\end{tabular}

Tabla 71. Equilibrio de Hardy-Weinberg

\begin{tabular}{|c|c|c|}
\hline Estadístico & gl & Sig. \\
\hline \hline 5,8065 & 1 & 0,0160 \\
\hline
\end{tabular}

Se rechaza la hipótesis de equilibrio.

\subsection{3.- TODOS LOS CONTROLES}

\section{I.- Polimorfismo P53 Exón 4}

Tabla 72. Equilibrio de Hardy-Weinberg

\begin{tabular}{|c|c|c|}
\hline Estadístico & $g l$ & Sig. \\
\hline \hline 3,6342 & 1 & 0,0566 \\
\hline
\end{tabular}

No se rechaza la hipótesis de equilibrio. 


\section{II.- Polimorfismo P53 Intron 3}

Tabla 73. Equilibrio de Hardy-Weinberg

\begin{tabular}{|c|c|c|}
\hline Estadístico & gl & Sig. \\
\hline \hline 1,1069 & 1 & 0,2928 \\
\hline
\end{tabular}

No se rechaza la hipótesis de equilibrio.

\subsection{4.- CASOS}

\section{I- Polimorfismo ERCC1}

Tabla 74. Equilibrio de Hardy-Weinberg

\begin{tabular}{|c|c|c|}
\hline Estadístico & gl & Sig. \\
\hline \hline 0,1322 & 1 & 0,7161 \\
\hline
\end{tabular}

No se rechaza la hipótesis de equilibrio.

\section{II- Polimorfismo XRCC1}

Tabla 75. Equilibrio de Hardy-Weinberg

\begin{tabular}{|c|c|c|}
\hline Estadístico & $\boldsymbol{g l}$ & Sig. \\
\hline 1,1142 & 1 & 0,2912 \\
\hline
\end{tabular}

No se rechaza la hipótesis de equilibrio.

\section{III- Polimorfismo P53 Exón 4}

En este polimorfismo no se cumple el Equilibrio de Hardy-Weinberg. 
Tabla 76. Tabla de frecuencias

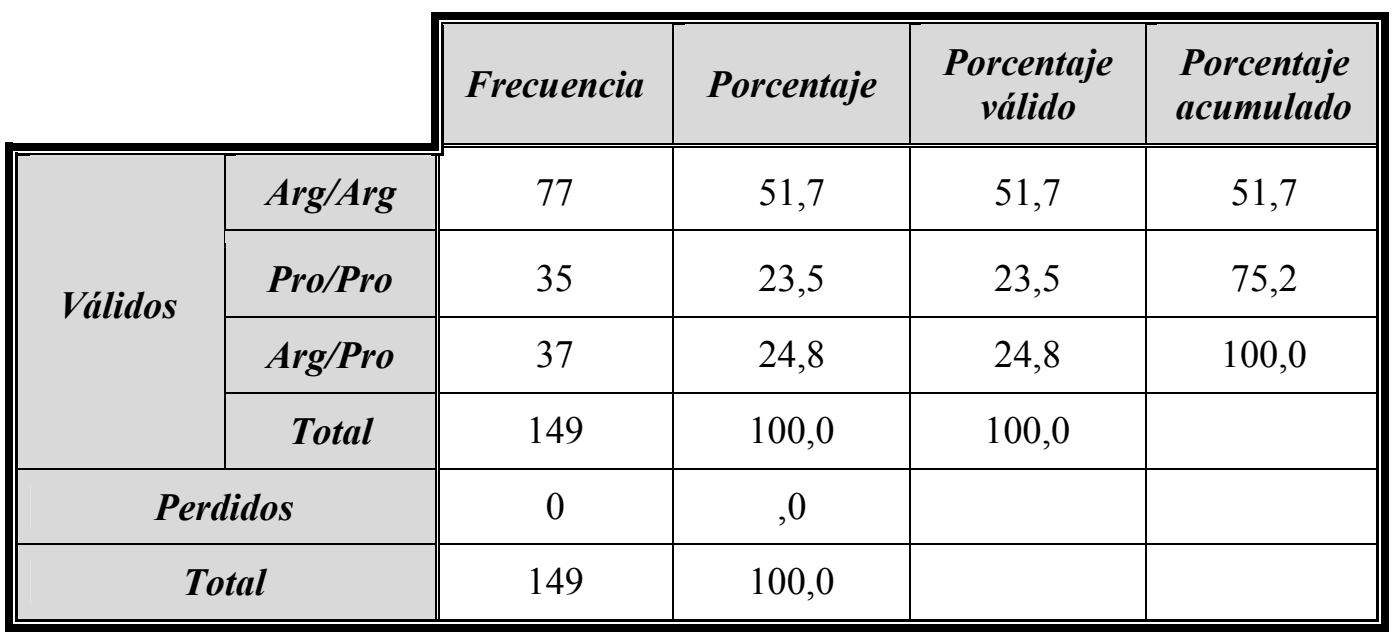

Tabla 77. Frecuencias alélicas

\begin{tabular}{|c|c|c|}
\hline Alelo & Frecuencia absoluta & Frecuencia relativa \\
\hline \hline Arg & 96 & 0,6409 \\
\hline Pro & 54 & 0,3591 \\
\hline
\end{tabular}

Tabla 78. Frecuencias genotípicas

\begin{tabular}{|c|c|c|c|c||}
\hline \multirow{2}{*}{ Genotipo } & \multicolumn{2}{|c|}{ Frecuencia observada } & \multicolumn{2}{c|}{ Frecuencia esperada } \\
\cline { 2 - 5 } & Absoluta & Relativa & Absoluta & Relativa \\
\hline ArgArg & 77 & 0,5168 & 61 & 0,4108 \\
\hline ProPro & 35 & 0,2349 & 19 & 0,1289 \\
\hline ArgPro & 37 & 0,2483 & 69 & 0,4603 \\
\hline
\end{tabular}

Tabla 79. Equilibrio de Hardy-Weinberg

\begin{tabular}{|c|c|c|}
\hline Estadístico & $\boldsymbol{g l}$ & Sig. \\
\hline \hline 31,5954 & 1 & 0,0000 \\
\hline
\end{tabular}

Se rechaza la hipótesis de equilibrio. 


\section{IV- Polimorfismo P53 Intron 3}

Tabla 80. Equilibrio de Hardy-Weinberg

\begin{tabular}{|c|c|c|}
\hline Estadístico & gl & Sig. \\
\hline \hline 0,6603 & 1 & 0,4164 \\
\hline
\end{tabular}

No se rechaza la hipótesis de equilibrio.

\section{2.- TESTS DE ASOCIACION}

El análisis más natural de asociación entre el genotipo y si el individuo es caso o control es contrastar la hipótesis de no asociación en la tabla de contingencia $2 \times 3$ que contiene las frecuencias de cada uno de los 3 genotipos en los casos y en los controles. Para ello se puede utilizar el contraste chi-cuadrado de Pearson o el test exacto de Fisher.

Lo que se hace en este caso es comparar los valores observados de cada genotipo con los valores esperados asumiendo que los casos y los controles tienen frecuencias genotípicas idénticas. También es posible analizar este tipo de datos, asumiendo un modelo genético preestablecido. Se van a analizar los siguientes modelos:

a) Modelo dominante. Se hace la suposición de que portar un determinado alelo incrementa el riesgo de padecer la enfermedad.

b) Modelo recesivo. Se hace la suposición de que portar dos copias de un alelo incrementa el riesgo de padecer la enfermedad.

c) Modelo multiplicativo. Se trata de un análisis por alelos y no por genotipos, comparando el número total de alelos de cada tipo en casos y controles, independientemente del genotipo del que provengan. La hipótesis de este modelo es que el riesgo de padecer la enfermedad se incrementa en un valor fijo por cada alelo que se porte (por ejemplo, se incrementa por $\mathrm{r}$ el riesgo si se porta el alelo $\mathrm{B}$, entonces, individuos con genotipo $\mathrm{AB}$ tendrán un riesgo $\mathrm{r}$ e individuos con genotipo 
$\mathrm{BB}, \mathrm{r}^{2}$ ). Para que este modelo sea apropiado es muy importante que tanto los casos como los controles estén en equilibrio Hardy - Weinberg.

d) Modelo aditivo. La hipótesis de este modelo es que el riesgo de los heterocigotos $(\mathrm{AB})$ es la mitad del riesgo de los homocigotos. Los contrastes generales usados en tablas de contingencia, no tienen mucha potencia en este supuesto. Se utiliza el test de Cochran-Armitage para tendencias.

\subsection{1.- CONTROLES CON 65 AÑOS O MÁS}

\section{I.- ERCC1}

\section{Modelo general}

Tabla 81. Tabla de contingencia de los genotipos de ERCC1 según grupo experimental caso o control de 65 años o más.

\begin{tabular}{|c|c|c|c|c|c|}
\hline & & \multicolumn{3}{|c|}{ ERCC1 } & \multirow[t]{2}{*}{ Total } \\
\hline & & $A / A$ & $G / G$ & $A / G$ & \\
\hline \multirow{2}{*}{ Grupo } & Caso & $63(43,75 \%)$ & $18(12,5 \%)$ & $63(43,75 \%)$ & $144(100 \%)$ \\
\hline & Control & $60(41,09 \%)$ & $21(14,38 \%)$ & $65(44,52 \%)$ & $146(100 \%)$ \\
\hline \multicolumn{2}{|c|}{ Total } & 123 & 39 & 128 & 290 \\
\hline
\end{tabular}

$(\mathrm{p}<0,05)$

No se rechaza la hipótesis de independencia.(Chi-cuadrado 0,321; $\mathrm{p}$ valor 0,852 ). No hay evidencias de que exista una asociación entre desarrollar cáncer de pulmón y ser portador de un genotipo específico en este SNP.

\section{$\checkmark$ Modelo dominante/Modelo recesivo}

- Hipótesis 1: portar alelo A o portar genotipo GG incrementa el riesgo.

No se rechaza la hipótesis de independencia (chi-cuadrado 0,221; p-valor 0,638). No hay evidencias de que portar el alelo A o equivalentemente el genotipo GG incremente el riesgo de padecer cáncer de pulmón. 
- Hipótesis 2: portar alelo G o portar genotipo AA incrementa el riesgo

No se rechaza la hipótesis de independencia (chi-cuadrado 0,209; p-valor 0,647). No hay evidencias de que portar el alelo $G$ o equivalentemente el genotipo AA incremente el riesgo de padecer cáncer de pulmón.

\section{Modelo multiplicativo}

Tabla 82. Tabla de contingencia de los alelos de ERCC1 según grupo experimental caso o control de 65 años o más

\begin{tabular}{|c|c|c|c|c|}
\hline & & \multicolumn{2}{|c|}{ ERCC1 } & \multirow{2}{*}{ Total } \\
\hline & & $A$ & $\boldsymbol{G}$ & \\
\hline \multirow{2}{*}{ Grupo } & Caso & $189(65,62 \%)$ & $99(34,37 \%)$ & $288(100 \%)$ \\
\hline & Control & $185(63,35 \%)$ & $107(36,64 \%)$ & $292(100 \%)$ \\
\hline \multicolumn{2}{|c|}{ Total } & 374 & 206 & 580 \\
\hline
\end{tabular}

$(\mathrm{p}<0,05)$

No se rechaza la hipótesis de independencia.(Chi-cuadrado 0,326 ; p valor 0,568 ) No hay evidencias de que portar un determinado alelo en este SNP incremente en riesgo de padecer cáncer de pulmón.

\section{$\checkmark$ Modelo aditivo}

Utilizando el Tests de Cochran Armitage, no rechazamos la hipótesis de que los heterocigotos tengan la mitad de riesgo de los homocigotos (Cochran Armitage -0,1918; p-valor 0,8470 ) 


\section{II.- XRCC1}

\section{Modelo general}

Tabla 83. Tabla de contingencia de los genotipos de ERCC1 según grupo experimental caso o control de 65 años o más.

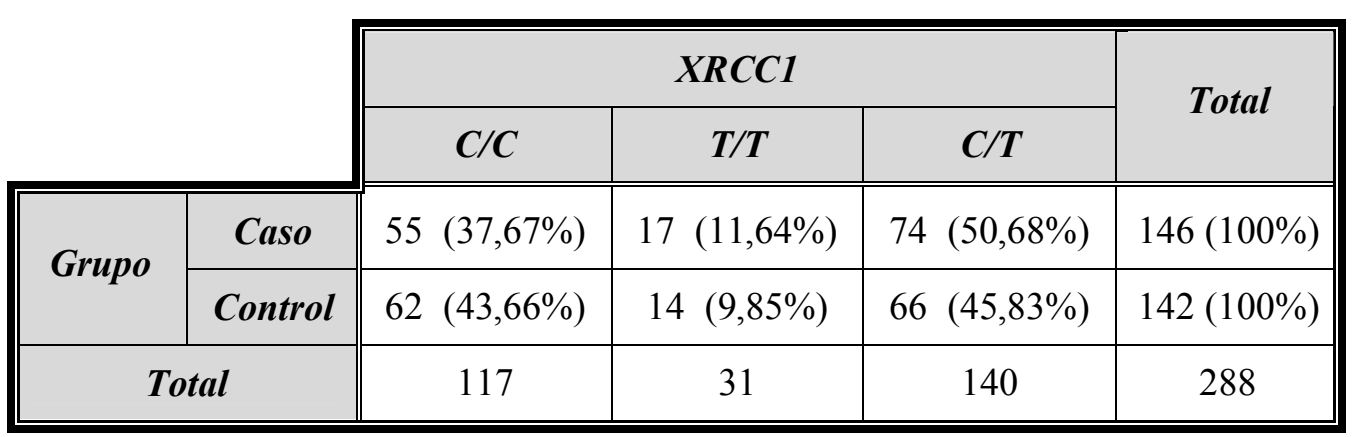

$(\mathrm{p}<0,05)$

No se rechaza la hipótesis de independencia.(Chi-cuadrado 1,111 ; $p$ valor 0,574 ) No hay evidencias de que exista una asociación entre desarrollar cáncer de pulmón y ser portador de un genotipo específico en este SNP.

\section{Modelo dominante / Modelo recesivo}

- Hipótesis 1: portar alelo $\mathrm{C}$ o portar genotipo TT incrementa el riesgo

No se rechaza la hipótesis de independencia (chi-cuadrado 0,239; p-valor 0,625). No hay evidencias de que portar el alelo C o equivalentemente el genotipo TT incremente el riesgo de padecer cáncer de pulmón.

- Hipótesis 2: portar alelo $\mathrm{T}$ o portar genotipo $\mathrm{CC}$ incrementa el riesgo

No se rechaza la hipótesis de independencia (chi-cuadrado 1,071; p-valor 0,301). No hay evidencias de que portar el alelo $\mathrm{T}$ o equivalentemente el genotipo $\mathrm{CC}$ incremente el riesgo de padecer cáncer de pulmón. 


\section{Modelo multiplicativo}

Tabla 84. Tabla de contingencia de los alelos de XRCC1 según grupo experimental caso o control de 65 años o más.

\begin{tabular}{|c|c|c|c|c||}
\cline { 3 - 5 } \multicolumn{1}{c|}{} & \multicolumn{2}{c||}{ XRCC1 } & \multirow{2}{*}{ Total } \\
\cline { 3 - 5 } \multicolumn{1}{c|}{} & $\boldsymbol{C}$ & $\boldsymbol{T}$ & \\
\hline \multirow{2}{*}{ Grupo } & Caso & $184(63 \%)$ & $108(37 \%)$ & $292(100 \%)$ \\
\cline { 2 - 5 } & Control & $190(66,9 \%)$ & $94(33,1 \%)$ & $284(100 \%)$ \\
\hline \multicolumn{2}{|c|}{ Total } & 374 & 202 & 576 \\
\hline
\end{tabular}

$(\mathrm{p}<0,05)$

No se rechaza la hipótesis de independencia.(Chi-cuadrado 0,956 ; $p$ valor 0,328 ) No hay evidencias de que portar un determinado alelo en este SNP incremente en riesgo de padecer cáncer de pulmón.

\section{$\checkmark$ Modelo aditivo}

Utilizando el Tests de Cochran Armitage, no se rechaza la hipótesis de que los heterocigotos tengan la mitad de riesgo de los homocigotos (Cochran Armitage 0,3163; p-valor 0,3759$)$

\section{III.- P53 Exón 4}

Recordar que en este SNP en la muestra de controles con 65 años o más no se verifica el equilibrio de Hardy - Weinberg.

\section{Modelo general}

Tabla 85. Tabla de contingencia de los genotipos del codon 72 de p53 según grupo experimental caso o control de 65 años o más.

\begin{tabular}{|c|c|c|c|c|c|}
\hline & & \multicolumn{3}{|c|}{ P53 } & \multirow{2}{*}{ Total } \\
\hline & & Arg/Arg & Pro/Pro & Arg/Pro & \\
\hline \multirow{2}{*}{ Grupo } & Caso & $77(51,67 \%)$ & $35(23,48 \%)$ & $37(24,83 \%)$ & $149(100 \%)$ \\
\hline & Control & $90(59,6 \%)$ & $15(9,93 \%)$ & $46(30,46 \%)$ & $151(100 \%)$ \\
\hline \multicolumn{2}{|c|}{ Total } & 167 & 50 & 83 & 300 \\
\hline
\end{tabular}

$(\mathrm{p}<0,05)$ 
No se rechaza la hipótesis de independencia (Chi-cuadrado 9,975; p valor 0,007). Para medir la asociación utilizamos las odds ratio parciales.

Tabla 86. Estimación de las Odds ratio parciales de los diferentes genotipos del codon 72 de p53 según grupo experimental caso o control de 65 años o más.

\begin{tabular}{|c|c|c|c|c|}
\hline & & \multirow{2}{*}{ Valor } & \multicolumn{2}{|c|}{ Intervalo de confianza 95\% } \\
\hline & & & Inferior & Superior \\
\hline \multirow{2}{*}{ Arg/Arg vs Pro/Pro } & Odds ratio (Caso / Control) &, 367 & ,186 & ,722 \\
\hline & $N^{o}$ de casos válidos & 217 & & \\
\hline \multirow{2}{*}{ Arg/Arg vs Arg/Pro } & Odds ratio (Caso / Control) & 1,064 & ,627 & 1,805 \\
\hline & $N^{o}$ de casos válidos & 250 & & \\
\hline \multirow{2}{*}{ Pro/Pro vs Arg/Pro } & Odds ratio (Caso / Control) & 2,901 & 1,379 & 6,103 \\
\hline & $N^{o}$ de casos válidos & 133 & & \\
\hline
\end{tabular}

Resultan significativas las comparaciones entre Pro/Pro y el resto. Portar el genotipo Pro/Pro aumenta el riesgo de padecer cáncer de pulmón. Es 2,725 veces más probable encontrar el genotipo Pro/Pro en lugar de Arg/Arg entre los casos con cáncer. Es 2,901 veces más probable encontrar el genotipo Pro/Pro en lugar de Arg/Pro entre los casos con cáncer.

\section{Modelo dominante / Modelo recesivo}

- Hipótesis 1: portar alelo Arg o portar genotipo Pro/Pro incrementa el riesgo

Se rechaza la hipótesis de independencia (Chi-cuadrado 9,923; p-valor 0,002).

Para cuantificar el riesgo utilizamos la odds ratio:

Tabla 87. Estimación de la odds-ratio para el alelo Arg del codon 72 de p53 en los controles mayores de 65 años

\begin{tabular}{|l|c|c|c||}
\cline { 3 - 4 } \multicolumn{1}{c|}{} & \multirow{2}{*}{ Valor } & \multicolumn{2}{c|}{ Intervalo de confianza al 95\% } \\
\cline { 3 - 5 } \multicolumn{1}{c|}{} & & Inferior & Superior \\
\hline Odds ratio (Caso/Control) &, 359 &, 187 &, 691 \\
\hline N de casos válidos & 300 & & \\
\hline
\end{tabular}

Estudio de los polimorfismos de genes reparadores en población fumadora con y sin cáncer de pulmón 
Si consideramos el modelo dominante, ser portador de Arg es un factor de protección o equivalentemente en el modelo recesivo, ser portador del genotipo Pro/Pro es un factor de riesgo. Es 2,786 veces más probable encontrar el genotipo Pro/Pro entre los casos de cáncer.

- Hipótesis 2: portar alelo Pro o portar genotipo Arg/Arg incrementa el riesgo

No se rechaza la hipótesis de independencia (Chi-cuadrado 1,909; p-valor 0,167). No hay evidencias de que portar el alelo Pro o equivalentemente el genotipo Arg/Arg incremente el riesgo de padecer cáncer de pulmón.

\section{Modelo multiplicativo}

No hay equilibrio ni en los casos ni en los controles por lo que no se prueba este modelo.

\section{$\checkmark$ Modelo aditivo}

Utilizando el Tests de Cochran Armitage, no se rechaza la hipótesis de que los heterocigotos tengan la mitad de riesgo de los homocigotos (Cochran Armitage 0,1554; p-valor 0,8765$)$

\section{IV.- P53 intron 3}

\section{Modelo general}

Tabla 88. Tabla de contingencia de los genotipos del intron 3 de p53 según grupo experimental caso o control de 65 años o más.

\begin{tabular}{|c|c|c|c|c|c|}
\hline & & \multicolumn{3}{|c|}{ P53 intron 3} & \multirow{2}{*}{ Total } \\
\hline & & $106 b p$ & $90 b p$ & $106+90 b p$ & \\
\hline \multirow{2}{*}{ Grupo } & Caso & $2(1,34 \%)$ & $107(71,81 \%)$ & $40(26,84 \%)$ & $149(100 \%)$ \\
\hline & Control & $2(1,32 \%)$ & $103(68,21 \%)$ & $46(30,46 \%)$ & $151(100 \%)$ \\
\hline \multicolumn{2}{|c|}{ Total } & 4 & 210 & 86 & 300 \\
\hline
\end{tabular}

$(\mathrm{p}<0,05)$ 
No se rechaza la hipótesis de independencia (Fisher 0,607; p valor 0,820). No hay evidencias de que exista una asociación entre desarrollar cáncer de pulmón y ser portador de un genotipo específico en este SNP.

\section{Modelo dominante / Modelo recesivo}

- Hipótesis 1: portar alelo 106 bp o portar genotipo 90bp incrementa el riesgo

No se rechaza la hipótesis de independencia (Chi-cuadrado 0,463; p-valor 0,496). No hay evidencias de que portar el alelo 106bp o equivalentemente el genotipo $90 \mathrm{bp}$ incremente el riesgo de padecer cáncer de pulmón.

- Hipótesis 2: portar alelo 90bp o portar genotipo 106bp incrementa el riesgo

No se rechaza la hipótesis de independencia (Chi-cuadrado $<0,001$; p-valor 0,989). No hay evidencias de que portar el alelo 90bp o equivalentemente el genotipo 106bp incremente el riesgo de padecer cáncer de pulmón.

\section{Modelo multiplicativo}

Tabla 89. Tabla de contingencia de los alelos del intron 3 de p53 según grupo experimental caso o control de 65 años o más.

\begin{tabular}{|c|c||c|c|c|}
\cline { 3 - 5 } \multicolumn{1}{c|}{} & \multicolumn{2}{c|}{ P53 intron 3 } & \multirow{2}{*}{ Total } \\
\cline { 3 - 5 } \multicolumn{2}{c|}{} & $\mathbf{1 0 6 b p}$ & $\mathbf{9 0 b p}$ & \\
\hline \multirow{2}{*}{ Grupo } & Caso & $44(14,76 \%)$ & $254(85,23 \%)$ & $298(100 \%)$ \\
\cline { 2 - 5 } & Control & $50(16,55 \%)$ & $252(83,45 \%)$ & $302(100 \%)$ \\
\hline \multicolumn{2}{|c|}{ Total } & 94 & 506 & 600 \\
\hline
\end{tabular}

$(\mathrm{p}<0,05)$

No se rechaza la hipótesis de independencia.(Chi-cuadrado 0,364; p valor 0,546) No hay evidencias de que portar un determinado alelo en este SNP incremente en riesgo de padecer cáncer de pulmón. 


\section{Modelo aditivo}

Utilizando el Tests de Cochran Armitage, no se rechaza la hipótesis de que los heterocigotos tengan la mitad de riesgo de los homocigotos (Cochran Armitage -1,4085; $\mathrm{p}$ valor 0,1590$)$.

\subsection{2.- CONTROLES CON MENOS DE 65 AÑOS}

\section{I.- P53 Exón 4}

\section{Modelo general}

Tabla 90. Tabla de contingencia de los genotipos del codon 72 de p53 según grupo experimental caso o control de menos de 65 años.

\begin{tabular}{|c|c|c|c|c|c|}
\cline { 3 - 6 } \multicolumn{1}{c|}{} & \multicolumn{3}{c|}{ P53 } & \multirow{2}{*}{ Total } \\
\cline { 2 - 6 } & \multirow{2}{*}{\multicolumn{1}{c|}{ Arg/Arg }} & Pro/Pro & Arg/Pro & \\
\hline \multirow{2}{*}{ Grupo } & Caso & $77(51,67 \%)$ & $35(23,48 \%)$ & $37(24,83 \%)$ & $149(100 \%)$ \\
\cline { 2 - 6 } & \multirow{2}{*}{ Control } & $77(49,67 \%)$ & $15(9,67 \%)$ & $63(40,64 \%)$ & $155(100 \%)$ \\
\hline \multicolumn{2}{|c|}{ Total } & 154 & 50 & 100 & 304 \\
\hline
\end{tabular}

$(\mathrm{p}<0,05)$

Se rechaza la hipótesis de independencia (Chi-cuadrado 14,647; p valor 0,001) Para medir la asociación utilizamos las odds ratio parciales:

Resultan significativas las tres comparaciones. Es 2,331 veces más probable encontrar el genotipo Pro/Pro en lugar de Arg/Arg entre los casos con cáncer. Es 1,703 veces más probable encontrar el genotipo Arg/Arg en lugar de Arg/Pro entre los casos con cáncer (estamos al borde de la significación). Es 3,973 veces más probable encontrar el genotipo Pro/Pro en lugar de Arg/Pro entre los casos con cáncer.

\section{Modelo dominante / Modelo recesivo}

- Hipótesis 1: portar alelo Arg o portar genotipo Pro/Pro incrementa el riesgo 
Se rechaza la hipótesis de independencia (Chi-cuadrado 10,547; p-valor 0,001). Para cuantificar el riesgo utilizamos la odds ratio:

Si consideramos el modelo dominante, ser portador de Arg es un factor de protección o equivalentemente en el modelo recesivo, ser portador del genotipo Pro/Pro es un factor de riesgo. Es 2,865 veces más probable encontrar el genotipo Pro/Pro entre los casos de cáncer.

- Hipótesis 2: portar alelo Pro o portar genotipo Arg/Arg incrementa el riesgo

No se rechaza la hipótesis de independencia (Chi-cuadrado 0,122; p-valor 0,727). No hay evidencias de que portar el alelo Pro o equivalentemente el genotipo Arg/Arg incremente el riesgo de padecer cáncer de pulmón.

\section{$\checkmark$ Modelo multiplicativo} modelo.

No hay equilibrio en la muestra de los casos, por lo que no se prueba con este

\section{$\checkmark$ Modelo aditivo}

Utilizando el Tests de Cochran Armitage, no se rechaza la hipótesis de que los heterocigotos tengan la mitad de riesgo de los homocigotos (Cochran Armitage -1,7316; $\mathrm{p}$ valor 0,0833$)$.

\section{II.- P53 intron 3}

Recordar que en este SNP en la muestra de controles con menos de 65 años no se verifica el equilibrio de Hardy - Weinberg. 


\section{Modelo general}

Tabla 91. Estimación de las Odds ratio parciales de los diferentes genotipos del codon 72 de p53 según grupo experimental caso o control de menos de 65 años.

\begin{tabular}{|c|c|c|c|c|}
\hline & & \multirow{2}{*}{ Valor } & \multicolumn{2}{|c|}{ Intervalo de confianza al 95\% } \\
\hline & & & Inferior & Superior \\
\hline \multirow{2}{*}{ Arg/Arg vs Pro/Pro } & Odds ratio (Caso / Control) & ,429 & 217 & ,848 \\
\hline & $N$ de casos válidos & 204 & & \\
\hline \multirow{2}{*}{ Arg/Arg vs Arg/Pro } & Odds ratio (Caso / Control) & 1,703 & 1,018 & 2,848 \\
\hline & $N$ de casos válidos & 254 & & \\
\hline \multirow{2}{*}{ Pro/Pro vs Arg/Pro } & Odds ratio (Caso / Control) & 3,973 & 1,918 & 8,232 \\
\hline & $N$ de casos válidos & 150 & & \\
\hline
\end{tabular}

Tabla 92. Estimación de la odds-ratio para el alelo Arg del codon 72 de p53 en los controles menores de 65 años

\begin{tabular}{|c|c|c|c|}
\cline { 2 - 4 } \multicolumn{1}{c|}{} & \multirow{2}{*}{ Valor } & \multicolumn{2}{|c|}{ Intervalo de confianza al 95\% } \\
\cline { 3 - 4 } \multicolumn{1}{c|}{} & & Inferior & Superior \\
\hline \hline Odds ratio (Caso/Control) &, 349 &, 182 &, 671 \\
\hline N de casos válidos & 304 & & \\
\hline
\end{tabular}

Tabla 93. Tabla de contingencia de los genotipos del intrón 3 de p53 según grupo experimental caso o control de menos de 65 años.

\begin{tabular}{|c|c|c|c|c|c|}
\hline & & \multicolumn{3}{|c|}{ P53 intron 3} & \multirow{2}{*}{ Total } \\
\hline & & $106 b p$ & $90 b p$ & $106+90 b p$ & \\
\hline \multirow{2}{*}{ Grupo } & Caso & $2(1,34 \%)$ & $107(71,81 \%)$ & $40(26,84 \%)$ & $149(100 \%)$ \\
\hline & Control & $11(70,96 \%)$ & $104(67,09 \%)$ & $40(25,80 \%)$ & $155(100 \%)$ \\
\hline Total & & 13 & 211 & 80 & 304 \\
\hline
\end{tabular}

$(\mathrm{p}<0,05)$ 
Tabla 94. Estimación de las Odds ratio parciales de los diferentes genotipos del intrón 3 de p53 según grupo experimental caso o control de 65 años o más.

\begin{tabular}{|c|c|c|c|c|}
\hline & & \\
\hline & & \multirow{2}{*}{ Valor } & \multicolumn{2}{|c|}{ Intervalo de confianza 95\% } \\
\hline & & & Inferior & Superior \\
\hline \multirow{2}{*}{$106 b p$ vs $90 b p$} & Odds ratio (Caso / Control) &, 177 & ,038 & ,817 \\
\hline & N de casos válidos & 224 & & \\
\hline \multirow{2}{*}{$106 b p$ vs $106+90 b p$} & Odds ratio (Caso / Control) &, 182 &, 038 & ,873 \\
\hline & N de casos válidos & 93 & & \\
\hline \multirow{2}{*}{$90 b p$ vs $106+90 b p$} & Odds ratio (Caso / Control) & 1,029 &, 615 & 1,721 \\
\hline & N de casos válidos & 291 & & \\
\hline
\end{tabular}

Se rechaza la hipótesis de independencia (Chi-cuadrado 6,157; p valor 0,046). Para medir la asociación utilizamos las odds ratio parciales.

Resultan significativas las comparaciones entre 106bp y el resto, parece que portar el genotipo 106bp disminuye el riesgo de padecer cáncer de pulmón. Es 5,650 veces más probable encontrar el genotipo 90bp en lugar de 106bp entre los casos con cáncer. Es 5,495 veces más probable encontrar el genotipo 106+90bp en lugar de 106bp entre los casos con cáncer.

\section{Modelo dominante/Modelo recesivo}

- Hipótesis 1: portar alelo 106 bp o portar genotipo 90bp incrementa el riesgo

No se rechaza la hipótesis de independencia (Chi-cuadrado 0,796; p-valor 0,372). No hay evidencias de que portar el alelo 106bp o equivalentemente el genotipo $90 \mathrm{bp}$ incremente el riesgo de padecer cáncer de pulmón.

- Hipótesis 2: portar alelo 90bp o portar genotipo 106bp incrementa el riesgo

Se rechaza la hipótesis de independencia (Chi-cuadrado 6,146; p-valor 0,013). Para cuantificar el riesgo utilizamos la odds ratio: 
Tabla 95. Estimación de la odds-ratio para el alelo 90bp del intrón 3 de p53 en controles menores de 65 años

\begin{tabular}{|l|c|c|c|}
\cline { 2 - 4 } \multicolumn{1}{c|}{} & \multirow{2}{*}{ Valor } & \multicolumn{2}{|c|}{ Intervalo de confianza al 95\% } \\
\cline { 3 - 4 } \multicolumn{1}{c|}{} & & Inferior & Superior \\
\hline \hline Odds ratio (Caso / Control) &, 178 &, 039 &, 818 \\
\hline N de casos válidos & 304 & & \\
\hline
\end{tabular}

Si consideramos el modelo dominante, ser portador de $90 \mathrm{bp}$ es un factor de riesgo o equivalentemente en el modelo recesivo, ser portador del genotipo 106bp es un factor de protección. Es 5,618 veces más probable encontrar los genotipos 90bp y 106+90bp entre los casos de cáncer.

\section{Modelo multiplicativo}

No hay equilibrio en la muestra de los controles, por lo que no se prueba con este modelo.

\section{Modelo aditivo}

Utilizando el Tests de Cochran Armitage, no se rechaza la hipótesis de que los heterocigotos tengan la mitad de riesgo de los homocigotos (Cochran Armitage -1,1673; $\mathrm{p}$ valor 0,2431$)$.

\subsection{3.- CONTROLES TOTALES}

Consideramos los dos grupos control (menores de 65 y mayores o igual a 65 años) como un único grupo de controles.

\section{I.- P53 codon 72}

Modelo general 
Tabla 96. Tabla de contingencia de los genotipos del codon 72 de p53 según grupo experimental caso o control.

\begin{tabular}{|c|c|c|c|c|c|}
\cline { 3 - 5 } \multicolumn{2}{c|}{} & \multicolumn{3}{c|}{ P53 } & \multirow{2}{*}{ Total } \\
\cline { 3 - 6 } \multicolumn{2}{c|}{} & Arg/Arg & Pro/Pro & Arg/Pro & \\
\hline \multirow{2}{*}{ Grupo } & Caso & $77(51,67 \%)$ & $35(23,48 \%)$ & $37(24,83 \%)$ & $149(100 \%)$ \\
\cline { 2 - 6 } & Control & $167(54,57 \%)$ & $30(9,8 \%)$ & $109(35,62 \%)$ & $306(100 \%)$ \\
\hline \multicolumn{2}{|c|}{ Total } & 244 & 65 & 146 & 455 \\
\hline \hline
\end{tabular}

$(\mathrm{p}<0,05)$

Se rechaza la hipótesis de independencia (Chi-cuadrado 16,930; p valor $<0,001$ ) Para medir la asociación utilizamos las odds ratio parciales:

Tabla 97. Estimación de las Odds ratio parciales de los diferentes genotipos del codon 72 de p53 según grupo experimental caso.

\begin{tabular}{|c|c|c|c|c|}
\hline & & \\
\hline & & \multirow{2}{*}{ Valor } & \multicolumn{2}{|c|}{ Intervalo de confianza 95\% } \\
\hline & & & Inferior & Superior \\
\hline \multirow{2}{*}{ Arg/Arg vs Pro/Pro } & Odds ratio (Caso / Control) & ,395 &, 226 &, 690 \\
\hline & N de casos válidos & 309 & & \\
\hline \multirow{2}{*}{ Arg/Arg vs Arg/Pro } & Odds ratio (Caso / Control) & 1,358 &, 857 & 2,153 \\
\hline & N de casos válidos & 390 & & \\
\hline \multirow{2}{*}{ Pro/Pro vs Arg/Pro } & Odds ratio (Caso / Control) & 3,437 & 1,860 & 6,350 \\
\hline & N de casos válidos & 211 & & \\
\hline
\end{tabular}

Resultan significativas las comparaciones en las que interviene el genotipo Pro/Pro respecto al resto, parece que es más frecuente encontrar el genotipo Pro/Pro entre casos con cáncer. Es 2,532 veces más probable encontrar el genotipo Pro/Pro en lugar de Arg/Arg entre los casos con cáncer. Es 3,437 veces más probable encontrar el genotipo Pro/Pro en lugar de Arg/Pro entre los casos con cáncer. 


\section{Modelo dominante/Modelo recesivo}

- Hipótesis 1: portar alelo Arg o portar genotipo Pro/Pro incrementa el riesgo

Se rechaza la hipótesis de independencia (Chi-cuadrado 15,328; p-valor 0,001). Para cuantificar el riesgo utilizamos la odds ratio:

Tabla 98. Estimación de la odds-ratio para el alelo Arg del codon 72 de 553 en los controles totales

\begin{tabular}{|l|c|c|c|}
\cline { 2 - 4 } \multicolumn{1}{c|}{} & \multirow{2}{*}{ Valor } & \multicolumn{2}{|c|}{ Intervalo de confianza al 95\% } \\
\cline { 3 - 4 } \multicolumn{1}{c|}{} & & Inferior & Superior \\
\hline Odds ratio (Caso / Control) &, 354 &, 208 &, 604 \\
\hline$N^{\boldsymbol{o}}$ de casos válidos & 455 & & \\
\hline
\end{tabular}

Si consideramos el modelo dominante, ser portador de Arg es un factor de protección o equivalentemente en el modelo recesivo, ser portador del genotipo Pro/Pro es un factor de riesgo. Es 2,845 veces más probable encontrar el genotipo Pro/Pro entre los casos de cáncer.

- Hipótesis 2: portar alelo Pro o portar genotipo Arg/Arg incrementa el riesgo

No se rechaza la hipótesis de independencia (Chi-cuadrado 0,338; p-valor 0,561). No hay evidencias de que portar el alelo Pro o equivalentemente el genotipo Arg/Arg incremente el riesgo de padecer cáncer de pulmón.

\section{Modelo multiplicativo}

No hay equilibrio en la muestra de los casos, por lo que no se prueba este modelo.

\section{$\checkmark$ Modelo aditivo}

Utilizando el Tests de Cochran Armitage, no se rechaza la hipótesis de que los heterocigotos tengan la mitad de riesgo de los homocigotos (Cochran Armitage -0,8773; $\mathrm{p}$ valor 0,3803$)$. 


\section{II.- P53 intron 3}

Recordar que en este SNP en la muestra de controles con menos de 65 años no se verifica el equilibrio de Hardy-Weinberg.

Tabla 99. Tabla de contingencia de los genotipos del intron 3 de p53 según grupo experimental caso o control de 65 años o más.

\begin{tabular}{|c|c|c|c|c|c|}
\hline & & \multicolumn{3}{|c|}{ P53 intron 3} & \multirow{2}{*}{ Total } \\
\hline & & $106 b p$ & $90 b p$ & $106+90 b p$ & \\
\hline \multirow{2}{*}{ Grupo } & Caso & $2(1,34 \%)$ & $107(71,81 \%)$ & $40(26,84 \%)$ & $149(100 \%)$ \\
\hline & Control & $2(1,32 \%)$ & $103(68,21 \%)$ & $46(30,46 \%)$ & $151(100 \%)$ \\
\hline \multicolumn{2}{|l|}{ Total } & 4 & 210 & 86 & 300 \\
\hline
\end{tabular}

$(\mathrm{p}<0,05)$

No se rechaza la hipótesis de independencia (Fisher 0,607; p valor 0,820). No hay evidencias de que exista una asociación entre desarrollar cáncer de pulmón y ser portador de un genotipo específico en este SNP.

\section{Modelo dominante/Modelo recesivo}

- Hipótesis 1: portar alelo 106 bp o portar genotipo 90bp incrementa el riesgo

No se rechaza la hipótesis de independencia (Chi-cuadrado 0,813; p-valor 0,367). No hay evidencias de que portar el alelo 106bp o equivalentemente el genotipo 90 bp incremente el riesgo de padecer cáncer de pulmón.

- Hipótesis 2: portar alelo 90bp o portar genotipo 106bp incrementa el riesgo

No se rechaza la hipótesis de independencia (Chi-cuadrado 2,655; p-valor 0,103). No hay evidencias de que portar el alelo 90bp o equivalentemente el genotipo 106bp incremente el riesgo de padecer cáncer de pulmón. 


\section{Modelo multiplicativo}

Tabla 100. Tabla de contingencia de los alelos del intron 3 de p53 según grupo experimental caso o control.

\begin{tabular}{|c|c|c|c|c|}
\hline & & \multicolumn{2}{|c|}{ P53 intron 3} & \multirow{2}{*}{ Total } \\
\hline & & $106 b p$ & $90 b p$ & \\
\hline \multirow{2}{*}{ Grupo } & Caso & $44(14,76 \%)$ & $254(85,24 \%)$ & $298(100 \%)$ \\
\hline & Control & $112(18,3 \%)$ & $500(81,7 \%)$ & $612(100 \%)$ \\
\hline \multicolumn{2}{|l|}{ Total } & 156 & 754 & 910 \\
\hline
\end{tabular}

$(\mathrm{p}<0,05)$

No se rechaza la hipótesis de independencia.(Chi-cuadrado 1,764; $\mathrm{p}$ valor 0,184 ) No hay evidencias de que portar un determinado alelo en este SNP incremente en riesgo de padecer cáncer de pulmón.

\section{Modelo aditivo}

Utilizando el Tests de Cochran Armitage, no se rechaza la hipótesis de que los heterocigotos tengan la mitad de riesgo de los homocigotos (Cochran Armitage $0,3295$; $p$ valor 0,7418$)$. 


\section{3.- REGRESIÓN LOGÍSTICA}

Una manera más "sofisticada" de ver si existe o no asociación entre la enfermedad y el SNP es ajustar un modelo de regresión logística. Aporta beneficios a la hora de considerar varios SNP a la vez o incluir covariables.

\subsection{1.- CONTROLES CON 65 AÑOS O MÁS}

\section{I.- ERCC1}

Tabla 101. Ajuste del modelo de regresión logística para explicar la probabilidad de desarrollar cáncer en función de los diferentes genotipos de ERCC1 en los controles de 65 años ó más

\begin{tabular}{|c|c|c|c|c|c|c|c|c|}
\hline & \multirow{2}{*}{$\beta$} & \multirow{2}{*}{ E.T. } & \multirow{2}{*}{ Wald } & \multirow{2}{*}{$g l$} & \multirow{2}{*}{ Sig. } & \multirow{2}{*}{$O . R$} & \multicolumn{2}{|c|}{ I.C. $95,0 \%$ para O.R. } \\
\hline & & & & & & & Inferior & Superior \\
\hline ERCC1 & & & ,321 & 2 & ,852 & & & \\
\hline $\operatorname{ERCC1(1)}$ &, 080 & ,253 & , 100 & 1 &, 751 & 1,083 & 660 & 1,777 \\
\hline $\operatorname{ERCC1(2)}$ &,- 123 & ,367 & ,112 & 1 &, 737 &, 884 &, 431 & 1,814 \\
\hline Constante &,- 031 &, 177 &, 031 & 1 &, 860 & 969 & & \\
\hline
\end{tabular}

Ajustando el modelo de regresión logística el TRV no es significativo (chicuadrado 0,$321 ; p$-valor $=0,852$ ), es decir que no rechazamos la hipótesis de que los 3 coeficientes sean iguales y en consecuencia podemos suponer que individuos con distinto genotipos en ERCC1 tienen el mismo riesgo de padecer cáncer de pulmón.

$\beta_{0}$ no es significativamente distinta de 0 ( $\mathrm{p}$-valor $\left.=0,860\right)$. Su exp es menor que 1, es decir que tener $\mathrm{A} / \mathrm{G}$ en ERCC1 es un factor de protección frente al cáncer de pulmón, aunque no es significativo.

$\beta_{1}$ no es significativamente distinto de $0(\mathrm{p}$-valor $=0,751)$. La odds-ratio respecto de ser heterocigoto es 1,083 , es decir pacientes con A/A tienen más riesgo de padecer cáncer de pulmón que los pacientes portadores de $\mathrm{A} / \mathrm{G}$, pero no es estadísticamente significativo (IC $95 \% 0,660 ; 1,777$ ). 
$\beta_{2}$ no es significativamente distinto de 0 ( $\mathrm{p}$-valor $\left.=0,737\right)$. La odds-ratio respecto de ser heterocigoto es ,884, es decir pacientes con $\mathrm{G} / \mathrm{G}$ tienen más riesgo de padecer cáncer de pulmón que los pacientes portadores de $\mathrm{A} / \mathrm{G}$, pero no es estadísticamente significativo (IC 95\% 0,431; 1,814).

En conclusión, ERCC1 no presenta asociación con el cáncer de pulmón.

\section{II.- XRCC1}

Tabla 102. Ajuste del modelo de regresión logística para explicar la probabilidad de desarrollar cáncer en función de los diferentes genotipos de XRCC1 en los controles de 65 años ó más

\begin{tabular}{|c|c|c|c|c|c|c|c|c|}
\hline & \multirow{2}{*}{$\beta$} & \multirow{2}{*}{ E.T. } & \multirow{2}{*}{ Wald } & \multirow{2}{*}{$g l$} & \multirow{2}{*}{ Sig. } & \multirow{2}{*}{$O . R$. } & \multicolumn{2}{|c|}{ I.C. $95,0 \%$ para O.R. } \\
\hline & & & & & & & Inferior & Superior \\
\hline$X R C C 1$ & & & 1,109 & 2 & ,574 & & & \\
\hline$X R C C 1(1)$ &,- 234 &, 251 & 871 & 1 & ,351 & ,791 & ,484 & 1,294 \\
\hline$X R C C 1(2)$ &, 080 & ,399 & ,040 & 1 & 841 & 1,083 & ,496 & 2,366 \\
\hline Constante & ,114 & ,169 & ,457 & 1 & ,499 & 1,121 & & \\
\hline
\end{tabular}

Ajustando el modelo de regresión logística el TRV es significativo (chi-cuadrado $1,109 ;$ p-valor $=0,574)$, es decir que no rechazamos la hipótesis de que los 3 coeficientes sean iguales y en consecuencia podemos suponer que individuos con distinto genotipos en XRCC1 tienen el mismo riesgo de padecer cáncer de pulmón.

$\beta_{0}$ no es significativamente distinta de $0(p$-valor $=0,499)$. Su exp es mayor que 1 , es decir que tener $\mathrm{C} / \mathrm{T}$ en XRCC1 es un factor de riesgo frente al cáncer de pulmón, aunque no es significativo.

$\beta_{1}$ no es significativamente distinto de $0(\mathrm{p}$-valor $=0,351)$. La odds-ratio respecto de ser heterocigoto es 0,791 , es decir pacientes con $\mathrm{C} / \mathrm{C}$ tienen menos riesgo de padecer cáncer de pulmón que los pacientes portadores de $\mathrm{C} / \mathrm{T}$, pero no es estadísticamente significativo (IC 95\% 0,484; 1,294). 
$\beta_{2}$ no es significativamente distinto de 0 ( $\mathrm{p}$-valor $\left.=0,841\right)$. La odds-ratio respecto de ser heterocigoto es 1,083 , es decir pacientes con T/T tienen más riesgo de padecer cáncer de pulmón que los pacientes portadores de $\mathrm{C} / \mathrm{T}$, pero no es estadísticamente significativo (IC 95\% 0,496;2,366).

En conclusión, XRCC1 no presenta asociación con el cáncer de pulmón.

\section{III.- P53 codon 72}

Recordar que en este SNP en la muestra de controles con 65 años o más no se verifica el equilibrio de Hardy - Weinberg.

Tabla 103. Ajuste del modelo de regresión logística para explicar la probabilidad de desarrollar cáncer en función de los diferentes genotipos del codon 72 de p53 en los controles de 65 años ó más

\begin{tabular}{|c|c|c|c|c|c|c|c|c|}
\hline & \multirow{2}{*}{$\beta$} & \multirow{2}{*}{ E.T. } & \multirow{2}{*}{ Wald } & \multirow{2}{*}{$g l$} & \multirow{2}{*}{ Sig. } & \multirow{2}{*}{$O . R}$. & \multicolumn{2}{|c|}{ I.C. $95,0 \%$ para O.R. } \\
\hline & & & & & & & Inferior & Superior \\
\hline$p 53$ & & & 9,463 & 2 & ,009 & & & \\
\hline$p 53(1)$ &, 062 & ,270 &, 052 & 1 & 819 & 1,064 & ,627 & 1,805 \\
\hline p53(2) & 1,065 & ,379 & 7,877 & 1 &, 005 & 2,901 & 1,379 & 6,103 \\
\hline Constante &,- 218 & ,221 & ,972 & 1 &, 324 & 804 & & \\
\hline
\end{tabular}

Ajustando el modelo de regresión logística el TRV es significativo (chi-cuadrado 9,463; p-valor $=0,009)$, es decir que rechazamos la hipótesis de que los 3 coeficientes sean iguales y en consecuencia que individuos con distinto genotipos en P53 tengan el mismo riesgo de padecer cáncer de pulmón.

$\beta_{0}$ no es significativamente distinta de 0 ( $\mathrm{p}$-valor $\left.=0,324\right)$. Su exp es menor que 1, es decir que tener Arg/Pro en P53 es un factor de protección frente al cáncer de pulmón, aunque no es significativo. 
$\beta_{1}$ no es significativamente distinto de $0(\mathrm{p}$-valor $=0,819)$. La odds-ratio respecto de ser heterocigoto es 1,064, es decir pacientes con Arg/Arg tienen más riesgo de padecer cáncer de pulmón que los pacientes portadores de Arg/Pro, pero no es estadísticamente significativo (IC 95\% 0,627; 1,805).

$\beta_{2}$ es significativamente distinto de $0(\mathrm{p}$-valor $=0,005)$. La odds-ratio respecto de ser heterocigoto es 2,901, es decir pacientes con Pro/Pro tienen más riesgo de padecer cáncer de pulmón que los pacientes portadores de Arg/Pro. Este incremento de riesgo es estadísticamente significativo (IC 95\% 1,379; 6,103).

En conclusión, P53 presenta asociación con el cáncer de pulmón. Ser portador de Pro/Pro es un factor de riesgo.

\section{IV.- P53 intron 3}

Tabla 104. Ajuste del modelo de regresión logística para explicar la probabilidad de desarrollar cáncer en función de los diferentes genotipos del intrón 3 de p53 en los controles de 65 años ó más

\begin{tabular}{|c|c|c|c|c|c|c|c|c|}
\hline & \multirow{2}{*}{$\beta$} & \multirow{2}{*}{ E.T. } & \multirow{2}{*}{ Wald } & \multirow{2}{*}{$g l$} & \multirow{2}{*}{ Sig. } & \multirow{2}{*}{ O.R. } & \multicolumn{2}{|c|}{ I.C. $95,0 \%$ para $O . R$. } \\
\hline & & & & & & & Inferior & Superior \\
\hline p53_I3 & & & ,481 & 2 & ,786 & & & \\
\hline p53_I3(1) &, 140 & 1,023 & ,019 & 1 & ,891 & 1,150 &, 155 & 8,542 \\
\hline p53_I3(2) &, 178 & ,257 & ,481 & 1 & ,488 & 1,195 &, 723 & 1,975 \\
\hline Constante &,- 140 & ,216 & ,418 & 1 &, 518 & 870 & & \\
\hline
\end{tabular}

Ajustando el modelo de regresión logística el TRV no es significativo (chicuadrado 0,$481 ; p$-valor $=0,786$ ), es decir que no rechazamos la hipótesis de que los 3 coeficientes sean iguales y en consecuencia podemos suponer que individuos con distinto genotipos en el P53 Intron 3 tienen el mismo riesgo de padecer cáncer de pulmón. 
$\beta_{0}$ no es significativamente distinta de 0 ( $\mathrm{p}$-valor $\left.=0,518\right)$. Su exp es menor que 1, es decir que tener $106+90 \mathrm{bp}$ en P53 intron 3, es un factor de protección frente al cáncer de pulmón.

$\beta_{1}$ no es significativamente distinto de 0 ( $\mathrm{p}$-valor $\left.=0,891\right)$. La odds-ratio respecto de ser heterocigoto es 1,150 , es decir pacientes con $106 \mathrm{bp}$ tienen más riesgo de padecer cáncer de pulmón que los pacientes portadores de $106+90 \mathrm{bp}$, pero no es estadísticamente significativo (IC 95\% 0,155;8,542).

$\beta_{2}$ no es significativamente distinto de 0 ( $\mathrm{p}$-valor $\left.=0,488\right)$. La odds-ratio respecto de ser heterocigoto es 1,195 , es decir pacientes con $90 \mathrm{bp}$ tienen más riesgo de padecer cáncer de pulmón que los pacientes portadores de $106+90 \mathrm{bp}$, pero no es estadísticamente significativo (IC 95\% 0,$723 ; 1,975$ ).

En conclusión, P53 Intron 3 no presenta asociación con el cáncer de pulmón.

\subsection{2.- CONTROLES CON MENOS DE 65 AÑOS}

\section{I.- P53 codon 72}

Tabla 105. Ajuste del modelo de regresión logística para explicar la probabilidad de desarrollar cáncer en función de los diferentes genotipos del codon 72 de p53 en los controles menores de 65 años.

\begin{tabular}{|c|c|c|c|c|c|c|c|c|}
\hline & \multirow{2}{*}{$\beta$} & \multirow{2}{*}{ E.T. } & \multirow{2}{*}{ Wald } & \multirow{2}{*}{$g l$} & \multirow{2}{*}{ Sig. } & \multirow{2}{*}{ O.R. } & \multicolumn{2}{|c|}{ I.C. $95,0 \%$ para O.R. } \\
\hline & & & & & & & Inferior & Superior \\
\hline$p 53$ & & & 13,970 & 2 &, 001 & & & \\
\hline$p 53(1)$ & ,532 & ,262 & 4,113 & 1 & ,043 & 1,703 & 1,018 & 2,848 \\
\hline$p 53(2)$ & 1,380 & ,372 & 13,777 & 1 & ,000 & 3,973 & 1,918 & 8,232 \\
\hline Constante &,- 532 & ,207 & 6,603 & 1 & ,010 &, 587 & & \\
\hline
\end{tabular}

Ajustando el modelo de regresión logística el TRV es significativo (chi-cuadrado 13,970; $\mathrm{p}$-valor $=0,001)$, es decir que rechazamos la hipótesis de que los 3 coeficientes 
sean iguales y en consecuencia que individuos con distinto genotipos en P53 tengan el mismo riesgo de padecer cáncer de pulmón.

$\beta_{0}$ es significativamente distinta de 0 ( $\mathrm{p}$-valor $<0,010$ ). Su exp es menor que 1, es decir que tener Arg/Pro en P53 es un factor de protección frente al cáncer de pulmón.

$\beta_{1}$ es significativamente distinto de $0(\mathrm{p}$-valor $=0,043)$. La odds-ratio respecto de ser heterocigoto es 1,703, es decir pacientes con Arg/Arg tienen más riesgo de padecer cáncer de pulmón que los pacientes portadores de Arg/Pro. Este incremento de riesgo es estadísticamente significativo (IC 95\% 1,018;2,848).

$\beta_{2}$ es significativamente distinto de 0 (p-valor $\left.<0,001\right)$. La odds-ratio respecto de ser heterocigoto es 3,973, es decir pacientes con Pro/Pro tienen más riesgo de padecer cáncer de pulmón que los pacientes portadores de Arg/Pro. Este incremento de riesgo es estadísticamente significativo (IC 95\% 1,918; 8,232).

En conclusión, P53 presenta asociación con el cáncer de pulmón. Ser hetorocigoto en P53 es un factor de protección y ser homocigoto, en cualquiera de los dos casos, es un factor de riesgo.

\section{II.- P53 intron 3}

Recordar que en este SNP en la muestra de controles con menos de 65 años no se verifica el equilibrio de Hardy-Weinberg.

Tabla 106. Ajuste del modelo de regresión logística para explicar la probabilidad de desarrollar cáncer en función de los diferentes genotipos del intrón 3 de p53 en los controles menores de 65 años.

\begin{tabular}{|c|c|c|c|c|c|c|c|c|}
\hline & \multirow{2}{*}{$\beta$} & \multirow{2}{*}{ E.T. } & \multirow{2}{*}{ Wald } & \multirow{2}{*}{$g l$} & \multirow{2}{*}{ Sig. } & \multirow{2}{*}{$O . R$. } & \multicolumn{2}{|c|}{ I.C. $95,0 \%$ para $O . R$. } \\
\hline & & & & & & & Inferior & Superior \\
\hline p53_I3 & & & 4,935 & 2 & ,085 & & & \\
\hline p53_I3(1) & $-1,705$ & ,801 & 4,534 & 1 &, 033 & ,182 & ,038 & ,873 \\
\hline p53_I3(2) &, 028 & ,263 &, 012 & 1 & ,914 & 1,029 & ,615 & 1,721 \\
\hline Constante & ,000 & ,224 &, 000 & 1 & 1,000 & 1,000 & & \\
\hline
\end{tabular}

Estudio de los polimorfismos de genes reparadores en población fumadora con y sin cáncer de pulmón 
Ajustando el modelo de regresión logística el TRV no es significativo (chicuadrado 4,935; p-valor $=0,085)$, es decir que no rechazamos la hipótesis de que los 3 coeficientes sean iguales y en consecuencia podemos suponer que individuos con distinto genotipos en el P53 Intron 3 tienen el mismo riesgo de padecer cáncer de pulmón.

$\beta_{0}$ no es significativamente distinta de $0(\mathrm{p}$-valor $=1,000)$. Su exp es 1 , es decir que individuos con 106+90bp en P53 intron 3 tienen la misma probabilidad de enfermar que de no hacerlo.

$\beta_{1}$ es significativamente distinto de $0(\mathrm{p}$-valor $=0,033)$. La odds-ratio respecto de ser heterocigoto es 0,182 , es decir pacientes con 106bp tienen menos riesgo de padecer cáncer de pulmón que los pacientes portadores de 106+90bp. Este incremento es estadísticamente significativo (IC 95\% 0,038;0,873).

$\beta_{2}$ no es significativamente distinto de 0 ( $\mathrm{p}$-valor $\left.=0,914\right)$. La odds-ratio respecto de ser heterocigoto es 1,029 , es decir pacientes con $90 \mathrm{bp}$ tienen más riesgo de padecer cáncer de pulmón que los pacientes portadores de $106+90 \mathrm{bp}$, pero no es estadísticamente significativo (IC 95\% 0,615; 1,721).

En conclusión, P53 Intron 3 no presenta asociación con el cáncer de pulmón, sin embargo, pacientes que portan 106bp tienen significativamente menos riesgo que pacientes con 106+90bp. Hay que ser muy cautelosos con este resultado puesto que sólo hay 13 individuos portadores de 106bp. 


\subsection{3.- CONTROLES TOTALES}

Consideramos los dos grupos control (menores de 65 y mayores o igual a 65 años) como un único grupo de controles.

\section{I.- P53}

Tabla 107. Ajuste del modelo de regresión logística para explicar la probabilidad de desarrollar cáncer en función de los diferentes genotipos del codon 72 de 553 en todos los controles.

\begin{tabular}{|c|c|c|c|c|c|c|c|c|}
\hline & \multirow{2}{*}{$\beta$} & \multirow{2}{*}{ E.T. } & \multirow{2}{*}{ Wald } & \multirow{2}{*}{$g l$} & \multirow{2}{*}{ Sig. } & \multirow{2}{*}{$O . R}$. & \multicolumn{2}{|c|}{ I.C. $95,0 \%$ para O.R. } \\
\hline & & & & & & & Inferior & Superior \\
\hline$p 53$ & & & 16,069 & 2 &, 000 & & & \\
\hline p53(1) & ,306 & ,235 & 1,700 & 1 & 192 & 1,358 & 857 & 2,153 \\
\hline p53(2) & 1,235 & ,313 & 15,536 & 1 &, 000 & 3,437 & 1,860 & 6,350 \\
\hline Constante & $-1,080$ & ,190 & 32,245 & 1 &, 000 & ,339 & & \\
\hline
\end{tabular}

Ajustando el modelo de regresión logística el TRV es significativo (chi-cuadrado 16,069; p-valor $<0,001)$, es decir que se rechaza la hipótesis de que los 3 coeficientes sean iguales y en consecuencia que individuos con distinto genotipos tengan el mismo riesgo de padecer cáncer de pulmón.

$\beta_{0}$ es significativamente distinta de 0 (p-valor $<0,001$ ). Su exp es menor que 1 , es decir que tener Arg/Pro en P53 es un factor de protección frente al cáncer de pulmón.

$\beta_{1}$ no es significativamente distinto de 0 ( $\mathrm{p}$-valor $\left.=0,192\right)$. La odds-ratio respecto de ser heterocigoto es 1,358, es decir pacientes con Arg/Arg tiene más riesgo de padecer cáncer de pulmón que los pacientes portadores de Arg/Pro, pero no es estadísticamente significativo (IC 95\% 0,$857 ; 2,153$ ).

$\beta_{2}$ es significativamente distinto de 0 ( $\mathrm{p}$-valor $<0,001$ ). La odds-ratio respecto de ser heterocigoto es 3,437, es decir pacientes con Pro/Pro tienen más riesgo de padecer cáncer de pulmón que los pacientes portadores de Arg/Pro. Este incremento de riesgo es estadísticamente significativo (IC 95\% 1,860; 6,350). 
En conclusión, P53 presenta asociación con el cáncer de pulmón. Ser hetorocigoto en P53 es un factor de protección y ser portador de Pro/Pro es un factor de riesgo.

\section{II.- P53 intron 3}

Recordar que en este SNP en la muestra de controles con menos de 65 años no se verifica el equilibrio de Hardy - Weinberg.

Tabla 108. Ajuste del modelo de regresión logística para explicar la probabilidad de desarrollar cáncer en función de los diferentes genotipos del intrón 3 de p53 en todos los controles.

\begin{tabular}{|c|c|c|c|c|c|c|c|c|}
\hline & \multirow{2}{*}{$\beta$} & \multirow{2}{*}{ E.T. } & \multirow{2}{*}{ Wald } & \multirow{2}{*}{$g l$} & \multirow{2}{*}{ Sig. } & \multirow{2}{*}{$O . R$. } & \multicolumn{2}{|c|}{ I.C. $95,0 \%$ para O.R. } \\
\hline & & & & & & & Inferior & Superior \\
\hline p53_I3 & & & 2,601 & 2 & ,272 & & & \\
\hline p53_I3(1) & $-1,106$ &, 783 & 1,995 & 1 &, 158 & ,331 & 071 & 1,536 \\
\hline p53_I3(2) & 106 & 225 & ,219 & 1 & ,639 & 1,111 &, 714 & 1,729 \\
\hline Constante &,- 765 & ,191 & 15,997 & 1 & 000 & ,465 & & \\
\hline
\end{tabular}

Ajustando el modelo de regresión logística el TRV no es significativo (chicuadrado 2,601; $\mathrm{p}$-valor $=0,272$ ), es decir que no rechazamos la hipótesis de que los 3 coeficientes sean iguales y en consecuencia podemos suponer que individuos con distinto genotipos en el P53 Intron 3 tienen el mismo riesgo de padecer cáncer de pulmón.

$\beta_{0}$ es significativamente distinta de 0 (p-valor $\left.<0,001\right)$. Su exp es menor que 1, es decir que tener 106+90bp en P53 intron 3, es un factor de protección frente al cáncer de pulmón.

$\beta_{1}$ no es significativamente distinto de $0(\mathrm{p}$-valor $=0,158)$. La odds-ratio respecto de ser heterocigoto es 0,331 , es decir pacientes con 106bp tiene menos riesgo de padecer cáncer de pulmón que los pacientes portadores de $106+90 \mathrm{bp}$, pero no es estadísticamente significativo (IC 95\% 0,071; 1,536). 
$\beta_{2}$ no es significativamente distinto de 0 (p-valor $\left.=0,639\right)$. La odds-ratio respecto de ser heterocigoto es 1,111 , es decir pacientes con 90bp tienen más riesgo de padecer cáncer de pulmón que los pacientes portadores de $106+90 \mathrm{bp}$, pero no es estadísticamente significativo (IC 95\% 0,714; 1,729).

En conclusión, P53 Intron 3 no presenta asociación con el cáncer de pulmón.

\section{4.- TEST DE ASOCIACIÓN: MÚLTIPLES SNP}

Analizar la asociación de cada uno de los SNP por separado puede ocultar información acerca de su distribución conjunta. Por ello se analiza la asociación entre la enfermedad y todos los SNP. Ajustamos un modelo de regresión logística para todos los SNP a la vez incluyendo las interacciones entre los mismos, y empleamos un procedimiento de selección "stepwise" para determinar que SNP están más relaciones con el hecho de padecer o no cáncer de pulmón.

\subsection{1.- SÓLO VARIABLES GENÉTICAS}

\subsubsection{1.- CONTROLES CON 65 AÑOS o MÁS}


Tabla 109. Ajuste del modelo de regresión logística completo en el grupo control de 65 años o más

\begin{tabular}{|c|c|c|c|c|c|c|c|c|}
\hline & \multirow{2}{*}{$\beta$} & \multirow{2}{*}{ E.T. } & \multirow{2}{*}{ Wald } & \multirow{2}{*}{$g l$} & \multirow{2}{*}{ Sig. } & \multirow{2}{*}{ O.R. } & \multicolumn{2}{|c|}{ I.C. $95,0 \%$ para $O . R$} \\
\hline & & & & & & & Inf. & Sup. \\
\hline ERCC1 & & & 2,899 & 2 & 235 & & & \\
\hline $\operatorname{ERCC1(1)}$ &,- 712 & ,662 & 1,157 & 1 & ,282 &, 491 & 134 & 1,796 \\
\hline $\operatorname{ERCC1(2)}$ & $-1,636$ & 1,040 & 2,477 & 1 &, 116 &, 195 &, 025 & 1,494 \\
\hline$X R C C 1$ & & & ,934 & 2 & ,627 & & & \\
\hline XRCC1(1) &, 020 & ,649 & 001 & 1 &, 975 & 1,020 & ,286 & 3,643 \\
\hline$X R C C 1(2)$ & 1,850 & 1,930 &, 919 & 1 &, 338 & 6,361 & ,145 & 279,49 \\
\hline$P 53$ & & & ,958 & 2 & ,619 & & & \\
\hline P53(1) &, 077 &, 702 & 012 & 1 & ,913 & 1,080 & 273 & 4,276 \\
\hline P53(2) &, 856 &, 915 &, 876 & 1 & ,349 & 2,354 & ,392 & 14,134 \\
\hline P53i3 & & & 1,299 & 2 &, 522 & & & \\
\hline P53i3(1) & 1,327 & 1,503 &, 779 & 1 &, 377 & 3,768 & ,198 & 71,661 \\
\hline P53i3(2) &, 417 & ,648 & ,413 & 1 &, 520 & 1,517 & ,426 & 5,401 \\
\hline$E R C C 1 * X R C C 1$ & & & ,316 & 4 & ,989 & & & \\
\hline ERCC1(1) by XRCC1(1) &, 017 &, 583 &, 001 & 1 &, 977 & 1,017 &, 325 & 3,186 \\
\hline ERCC1(1) by XRCC1(2) &,- 351 &, 954 &, 135 & 1 &, 713 &, 704 & , 109 & 4,567 \\
\hline ERCC1(2) by XRCC1(1) &, 114 &, 934 &, 015 & 1 & ,903 & 1,121 &, 180 & 6,986 \\
\hline ERCC1(2) by XRCC1(2) & ,402 & 1,638 &, 060 & 1 &, 806 & 1,494 & 060 & 37,054 \\
\hline$E R C C 1 * P 53$ & & & ,922 & 4 & ,921 & & & \\
\hline ERCC1(1) by P53(1) &, 557 & 669 & 695 & 1 & ,404 & 1,746 & ,471 & 6,474 \\
\hline ERCC1(1) by P53(2) & ,205 &, 915 &, 050 & 1 &, 822 & 1,228 & 204 & 7,375 \\
\hline ERCC1(2) by P53(1) &, 736 & 1,100 &, 448 & 1 &, 503 & 2,088 & 242 & 18,024 \\
\hline ERCC1(2) by P53(2) & 21,404 & 17729,597 &, 000 & 1 & ,999 & $>>$ & 000 & . \\
\hline$E R C C 1 * P 53 i 3$ & & & 1,498 & 2 & ,473 & & & \\
\hline ERCC1(1) by P53i3(2) & ,667 & ,652 & 1,046 & 1 &, 307 & 1,948 &, 543 & 6,992 \\
\hline ERCC1(2) by P53i3(2) & 1,103 & 1,227 &, 807 & 1 &, 369 & 3,012 & ,272 & 33,379 \\
\hline$X R C C 1 * P 53$ & & & 3,717 & 4 & ,446 & & & \\
\hline XRCC1(1) by P53(1) &, 459 & ,672 &, 466 & 1 & ,495 & 1,582 & ,424 & 5,906 \\
\hline XRCC1(1) by P53(2) & $-1,029$ & 1,026 & 1,007 & 1 &, 316 & 357 & ,048 & 2,667 \\
\hline XRCC1(2) by P53(1) &,- 957 & 1,319 &, 526 & 1 &, 468 &, 384 & 029 & 5,096 \\
\hline XRCC1(2) by P53(2) & $-2,751$ & 1,766 & 2,425 & 1 &, 119 &, 064 & ,002 & 2,036 \\
\hline$X R C C 1 * P 53 i 3$ & & & 1,101 & 2 & ,577 & & & \\
\hline XRCC1(1) by P53i3(2) &,- 670 &, 653 & 1,051 & 1 & ,305 &, 512 & 142 & 1,841 \\
\hline XRCC1(2) by P53i3(2) &,- 695 & 1,537 & ,205 & 1 & ,651 & ,499 & 025 & 10,148 \\
\hline$p 53 * p 53 \_i 3$ & & & 5,234 & 3 &, 155 & & & \\
\hline p53(1) by p53_i3(1) & $-22,957$ & 40192,970 &, 000 & 1 & 1,000 &, 000 & ,000 & . \\
\hline p53(2) by p53_i3(1) &,- 920 & 699 & 1,733 & 1 &, 188 &, 399 &, 101 & 1,568 \\
\hline p53(2) by p53_i3(2) & 1,172 & 1,010 & 1,347 & 1 & ,246 & 3,230 & ,446 & 23,394 \\
\hline Constante & ,009 &, 540 & 000 & 1 & ,987 & 1,009 & & \\
\hline
\end{tabular}

Estudio de los polimorfismos de genes reparadores en población fumadora con y sin cáncer de pulmón 
Ninguna de las variables resulta estadísticamente significativa a la hora de explicar si un individuo desarrolla o no cáncer de pulmón.

Cuanto planteamos el procedimiento stepwise, el modelo se ajusta en 1 paso y se incluye el SNP P53. Se obtiene el modelo representado en la siguiente tabla:

Tabla 110. Ajuste del modelo de regresión logística a partir de la introducción/eliminación progresiva (Procedimiento stepwise) de los distintos polimorfismos del codon 72 de p53 en controles con 65 años o más

\begin{tabular}{|c|c|c|c|c|c|c|c|c|}
\hline & \multirow{2}{*}{$\beta$} & \multirow{2}{*}{ E.T. } & \multirow{2}{*}{ Wald } & \multirow{2}{*}{$g l$} & \multirow{2}{*}{ Sig. } & \multirow{2}{*}{$O . R$. } & \multicolumn{2}{|c|}{ I.C. $95,0 \%$ para O.R. } \\
\hline & & & & & & & Inferior & Superior \\
\hline$p 53$ & & & 9,463 & 2 &, 009 & & & \\
\hline p53(1) & 062 & 270 & 052 & 1 & 819 & 1,064 & 627 & 1,805 \\
\hline p53(2) & 1,065 & ,379 & 7,877 & 1 &, 005 & 2,901 & 1,379 & 6,103 \\
\hline Constante &,- 218 & 221 & 972 & 1 &, 324 & 804 & & \\
\hline
\end{tabular}

Este modelo pone de manifiesto que portar el genotipo Pro/Pro en el SNP P53, aumenta significativamente el riesgo de padecer cáncer de pulmón.

Tomando como punto de corte el 50\% (si un paciente tiene un riesgo pronosticado $>50 \%$ se considera que el modelo pronostica que desarrollará el cáncer), el modelo establecido clasifica a los pacientes según la tabla siguiente:

Tabla 111. Tabla de validez interna de los controles con 65 años o más

\begin{tabular}{|c|c|c|c|c|}
\hline \multirow{3}{*}{\multicolumn{2}{|c|}{ Observado }} & & & \multirow{3}{*}{$\begin{array}{c}\text { Porcentaje } \\
\text { correcto }\end{array}$} \\
\hline & & \multicolumn{2}{|c|}{ Desarrolla cáncer de pulmón } & \\
\hline & & No & Sí & \\
\hline \multirow{2}{*}{$\begin{array}{c}\text { Desarrolla cáncer } \\
\text { de pulmón }\end{array}$} & No & 136 & 15 & 90,1 \\
\hline & Sí & 114 & 35 & 23,5 \\
\hline \multicolumn{2}{|c|}{ Porcentaje global } & & & 57,0 \\
\hline
\end{tabular}


El modelo clasifica bien al 57\% de los pacientes, el 90,1\% de los pacientes control son bien clasificados (especificidad) y sólo el $23,5 \%$ de los casos se clasifican bien (sensibilidad). Esto pone de manifiesto que este modelo no es una buena herramienta de clasificación, especialmente para detectar el desarrollo de la enfermedad.

\subsubsection{2.- CONTROLES MENORES DE 65 AÑOS}

Tabla 112. Ajuste del modelo de regresión logística completo en el grupo control de menos de 65 años

\begin{tabular}{|c|c|c|c|c|c|c|c|c|}
\hline & \multirow{2}{*}{$\beta$} & \multirow{2}{*}{ E.T. } & \multirow{2}{*}{ Wald } & \multirow{2}{*}{$g l$} & \multirow{2}{*}{ Sig. } & \multirow{2}{*}{ O.R. } & \multicolumn{2}{|c|}{ I.C. $95,0 \%$ para O.R. } \\
\hline & & & & & & & Inferior & Superior \\
\hline p53 & --- & --- & 3,394 & 2 &, 183 & --- & --- & --- \\
\hline p53(1) & 668 &, 530 & 1,587 & 1 & ,208 & 1,950 & ,690 & 5,512 \\
\hline$p 53(2)$ & 1,012 & ,601 & 2,829 & 1 & ,093 & 2,750 & 846 & 8,939 \\
\hline p53_i3 & --- & --- &, 001 & 2 & ,999 & --- & --- & --- \\
\hline p53_i3(1) & 20,797 & 14210,361 &, 000 & 1 & ,999 &, 000 & 000 & --- \\
\hline p53_i3(2) &, 016 & ,429 &, 001 & 1 & ,970 & 1,016 & ,438 & 2,356 \\
\hline$p 53 * p 53 \_i 3$ & --- & --- & 1,066 & 4 & ,900 & - & --- & -- \\
\hline p53(1) by p53_i3(1) &,- 668 & 42631,082 &, 000 & 1 & 1,000 &, 513 & 000 & - \\
\hline p53(1) by p53_i3(2) &,- 309 & ,626 & ,244 & 1 & 621 &, 734 &, 215 & 2,503 \\
\hline p53(2) by p53_i3(1) & 20,191 & 14210,361 &, 000 & 1 & ,999 & $>>$ & 000 & --- \\
\hline p53(2) by p53_i3(2) &, 523 & ,794 &, 434 & 1 &, 510 & 1,687 & ,356 & 7,993 \\
\hline Constante &,- 405 & ,323 & 1,578 & 1 & ,209 & ,667 & & \\
\hline
\end{tabular}

Ninguna de las variables resulta estadísticamente significativa a la hora de explicar si un individuo desarrolla o no cáncer de pulmón. Cuanto planteamos el procedimiento stepwise, el modelo se ajusta en 2 pasos y se incluyen los dos SNP: P53 codon 72 y P53 intron 3. Obtenemos el modelo: 
Tabla 113. Ajuste del modelo de regresión logística a partir de la introducción/eliminación progresiva (Procedimiento stepwise) de los distintos polimorfismos del codon 72 y el intrón 3 de p53 en controles menores de 65 años

\begin{tabular}{|c|c|c|c|c|c|c|c|c|}
\hline & \multirow{2}{*}{$\beta$} & \multirow{2}{*}{$E . T}$. & \multirow{2}{*}{ Wald } & \multirow{2}{*}{$g l$} & \multirow{2}{*}{ Sig. } & \multirow{2}{*}{$O . R$. } & \multicolumn{2}{|c|}{ I.C. $95,0 \%$ para O.R. } \\
\hline & & & & & & & Inferior & Superior \\
\hline p53 & & & 14,152 & 2 &, 001 & & & \\
\hline p53(1) & ,442 & ,278 & 2,527 & 1 & ,112 & 1,555 & ,902 & 2,681 \\
\hline p53(2) & 1,452 & ,386 & 14,151 & 1 &, 000 & 4,271 & 2,005 & 9,101 \\
\hline P53i3 & & & 5,450 & 2 & ,066 & & & \\
\hline P53i3(1) & $-1,918$ &, 837 & 5,250 & 1 &, 022 &, 147 &, 028 & ,758 \\
\hline P53i3(2) &,- 013 &, 284 &, 002 & 1 & ,964 & ,987 &, 566 & 1,723 \\
\hline Constante &,- 421 &, 266 & 2,509 & 1 & ,113 &, 656 & & \\
\hline
\end{tabular}

Este modelo pone de manifiesto que

- Portar el genotipo Pro/Pro en el SNP P53, aumenta significativamente el riesgo de padecer cáncer de pulmón.

- Portar el genotipo 106bp en el SNP P53 Intron 3, disminuye significativamente el riesgo de padecer cáncer de pulmón.

Tomando como punto de corte el 50\% (si un paciente tiene un riesgo pronosticado $>50 \%$ se considera que el modelo pronostica que desarrollará el cáncer), el modelo establecido clasifica a los pacientes según la tabla:

Tabla 114. Tabla de validez interna de los controles menores de 65 años

\begin{tabular}{|c|c|c|c|c|}
\hline \multirow{3}{*}{\multicolumn{2}{|c|}{ Observado }} & & & \multirow{3}{*}{$\begin{array}{c}\text { Porcentaje } \\
\text { correcto }\end{array}$} \\
\hline & & \multicolumn{2}{|c|}{ Desarrolla cáncer de pulmón } & \\
\hline & & No & Sí & \\
\hline \multirow{2}{*}{$\begin{array}{c}\text { Desarrolla } \\
\text { cáncer de pulmón }\end{array}$} & No & 66 & 89 & 42,6 \\
\hline & Sí & 39 & 110 & 73,8 \\
\hline \multicolumn{2}{|c|}{ Porcentaje global } & & & 57,9 \\
\hline
\end{tabular}


El modelo clasifica bien al 57,9\% de los pacientes, el $42,6 \%$ de los pacientes control son bien clasificados (especificidad) y el 73,8\% de los casos se clasifican bien (sensibilidad).

\subsubsection{3.- CONTROLES TOTALES}

Tabla 115. Ajuste del modelo de regresión logística completo en el grupo control total

\begin{tabular}{|c|c|c|c|c|c|c|c|c|}
\hline & \multirow{2}{*}{$\beta$} & \multirow{2}{*}{ E.T. } & \multirow{2}{*}{ Wald } & \multirow{2}{*}{$g l$} & \multirow{2}{*}{ Sig. } & \multirow{2}{*}{$O . R$. } & \multicolumn{2}{|c|}{ I.C. $95,0 \%$ para O.R. } \\
\hline & & & & & & & Inferior & Superior \\
\hline$p 53$ & & & 4,640 & 2 &, 098 & & & \\
\hline p53(1) &, 748 & ,457 & 2,681 & 1 &, 102 & 2,113 &, 863 & 5,171 \\
\hline$p 53(2)$ & ,937 & ,494 & 3,601 & 1 &, 058 & 2,554 & ,970 & 6,725 \\
\hline$p 53 \_i 3$ & & &, 733 & 2 & 693 & & & \\
\hline p53_i3(1) & $-20,024$ & 14210,36 &, 000 & 1 & 999 & 000 &, 000 & - \\
\hline p53_i3(2) &, 331 & ,387 &, 733 & 1 & ,392 & 1,393 & ,652 & 2,974 \\
\hline$p 53 * p 53 \_i 3$ & & & 3,485 & 4 & ,480 & & & \\
\hline p53(1) by p53_i3(1) &,- 748 & 31775,33 &, 000 & 1 & 1,000 & ,473 &, 000 & - \\
\hline p53(1) by p53_i3(2) &,- 718 &, 547 & 1,725 & 1 & ,189 &, 488 &, 167 & 1,424 \\
\hline p53(2) by p53_i3(1) & 19,860 & 14210,36 &, 000 & 1 & ,999 & $>>$ &, 000 & - \\
\hline p53(2) by p53_i3(2) & ,436 & ,659 & ,437 & 1 & ,508 & 1,546 & ,425 & 5,628 \\
\hline Constante & $-1,179$ & 286 & 16,998 & 1 &, 000 & ,308 & & \\
\hline
\end{tabular}

Salvo la constante ninguna de las variables resulta estadísticamente significativa a la hora de explicar si un individuo desarrolla o no cáncer de pulmón. Cuanto planteamos el procedimiento stepwise, el modelo se ajusta en 1 paso y la única variable que interviene es el SNP P53. Obtenemos el modelo: 
Tabla 116. Ajuste del modelo de regresión logística a partir de la introducción/eliminación progresiva (Procedimiento stepwise) de los distintos polimorfismos del codon 72 de p53 en el grupo control total

\begin{tabular}{|c|c|c|c|c|c|c|c|c|}
\hline & \multirow{2}{*}{$\beta$} & \multirow{2}{*}{ E.T. } & \multirow{2}{*}{ Wald } & \multirow{2}{*}{$g l$} & \multirow{2}{*}{ Sig. } & \multirow{2}{*}{ O.R. } & \multicolumn{2}{|c|}{ I.C. $95,0 \%$ para O.R. } \\
\hline & & & & & & & Inferior & Superior \\
\hline$p 53$ & & & 16,069 & 2 &, 000 & & & \\
\hline p53(1) & ,306 &, 235 & 1,700 & 1 & ,192 & 1,358 & 857 & 2,153 \\
\hline p53(2) & 1,235 &, 313 & 15,536 & 1 &, 000 & 3,437 & 1,860 & 6,350 \\
\hline Constante & $-1,080$ &, 190 & 32,245 & 1 &, 000 & ,339 & & \\
\hline
\end{tabular}

Este modelo pone de manifiesto que portar el genotipo Pro/Pro en el SNP P53, aumenta significativamente el riesgo de padecer cáncer de pulmón.

Tomando como punto de corte el 50\% (si un paciente tiene un riesgo pronosticado $>50 \%$ se considera que el modelo pronostica que desarrollará el cáncer), el modelo establecido clasifica a los pacientes según la tabla siguiente:

Tabla 117. Tabla de validez interna de grupo control total

\begin{tabular}{|c|c|c|c|c|}
\hline \multicolumn{2}{|c|}{ Observado } & \multicolumn{2}{c|}{ Pronosticado } & \multirow{2}{*}{$\begin{array}{c}\text { Porcentaje } \\
\text { correcto }\end{array}$} \\
\cline { 3 - 5 } & \multicolumn{2}{|c|}{ Desarrolla cáncer de pulmón } & \\
\cline { 3 - 5 } & No & Sí & \\
\hline \multirow{2}{*}{$\begin{array}{c}\text { Desarrolla } \\
\text { cáncer de pulmón }\end{array}$} & No & 276 & 30 & 90,2 \\
\cline { 2 - 5 } & Sí & 114 & 35 & 23,5 \\
\hline \multicolumn{2}{|c|}{ Porcentaje global } & & & 68,4 \\
\hline
\end{tabular}

El modelo clasifica bien al 68,4\% de los pacientes, el 90,2\% de los pacientes control son bien clasificados (especificidad) y sólo el $23,5 \%$ de los casos se clasifican bien (sensibilidad). Esto pone de manifiesto que este modelo no es una buena herramienta de clasificación, especialmente para detectar el desarrollo de la enfermedad. 


\subsection{2.- INCLUYENDO VARIABLES NO GENÉTICAS}

\subsubsection{1.- RELACIÓN ENTRE LAS VARIABLES NO GENÉTICAS CON LOS SNP}

\section{I.- ERCC1}

\section{Edad}

Tabla 118. Tabla de contingencia según intervalos de edad y los genotipos de ERCC1

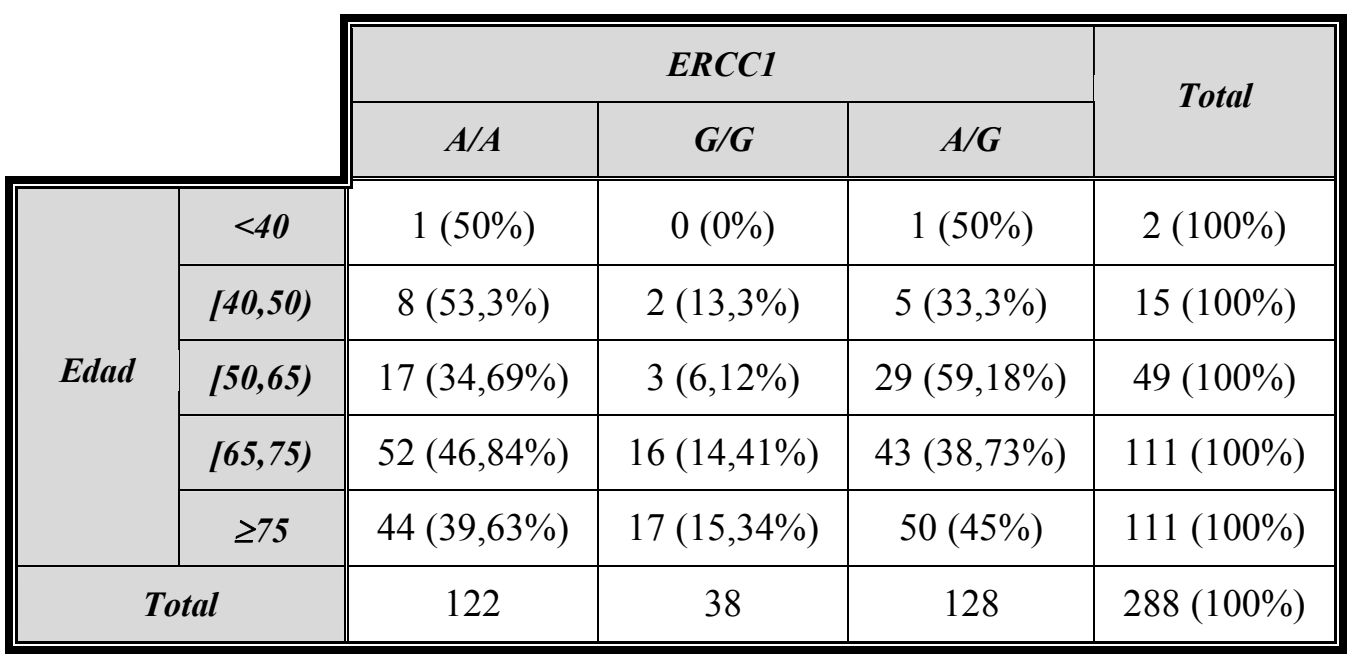

$(\mathrm{p}<0,05)$

No se rechaza la hipótesis de independencia (Razón de verosimilitud 8,682; p valor 0,370$)$. No hay evidencias de que exista una asociación entre el grupo de edad y ser portador de un genotipo específico en este SNP.

\section{Número de paquetes/día}

Tabla 119. Tabla de contingencia según número de paquetes/día y los genotipos de ERCC1

\begin{tabular}{|c|c|c|c|c|c||}
\cline { 3 - 6 } \multicolumn{1}{c|}{} & \multicolumn{3}{c|}{ ERCC1 } & \multirow{2}{*}{ Total } \\
\cline { 2 - 6 } \multicolumn{2}{c|}{} & $\boldsymbol{A} / \boldsymbol{A}$ & $\boldsymbol{G} / \boldsymbol{G}$ & $\boldsymbol{A} / \boldsymbol{G}$ & \\
\hline \multirow{2}{*}{ Paq./día } & $\leq \mathbf{1}$ & $63(42 \%)$ & $22(14,66 \%)$ & $65(43,33 \%)$ & $150(100 \%)$ \\
\cline { 2 - 6 } & $>\mathbf{1}$ & $60(43,16 \%)$ & $17(12,23 \%)$ & $62(44,6 \%)$ & $139(100 \%)$ \\
\hline \multicolumn{2}{|c|}{ Total } & 123 & 39 & 127 & 289 \\
\hline
\end{tabular}

$$
(\mathrm{p}<0,05)
$$


No se rechaza la hipótesis de independencia (Chi-cuadrado 0,367; $\mathrm{p}$ valor 0,832 ). No hay evidencias de que exista una asociación entre el número de paquetes fumados al día y ser portador de un genotipo específico en este SNP.

\section{Número de años fumando}

Tabla 120. Tabla de contingencia según número de años fumando y los genotipos de ERCC1

\begin{tabular}{|c|c|c|c|c|c|}
\hline & & \multicolumn{3}{|c|}{ ERCC1 } & \multirow{2}{*}{ Total } \\
\hline & & $A / A$ & $G / G$ & $A / G$ & \\
\hline \multirow{2}{*}{$\begin{array}{c}\text { Años } \\
\text { fumando }\end{array}$} & $<38$ años & $39(39 \%)$ & $14(14 \%)$ & $47(47 \%)$ & $100(100 \%)$ \\
\hline & $\geq 38$ años & $84(44,21 \%)$ & $25(13,15 \%)$ & $81(42,63 \%)$ & $190(100 \%)$ \\
\hline \multicolumn{2}{|c|}{ Total } & 123 & 39 & 128 & 290 \\
\hline
\end{tabular}

$(\mathrm{p}<0,05)$

No se rechaza la hipótesis de independencia (Chi-cuadrado 0,737 ; p valor 0,692 ). No hay evidencias de que exista una asociación entre el número de años fumados y ser portador de un genotipo específico en este SNP.

\section{II.- XRCC1}

\section{Edad}

Tabla 121. Tabla de contingencia según intervalos de edad y los genotipos de XRCCI

\begin{tabular}{|c|c|c|c|c|c|}
\hline & & \multicolumn{3}{|c|}{$X R C C 1$} & \multirow{2}{*}{ Total } \\
\hline & & $C / C$ & $T / T$ & $C / T$ & \\
\hline \multirow{5}{*}{ Edad } & $<40$ & $1(50 \%)$ & $0(0 \%)$ & $1(50 \%)$ & $2(100 \%)$ \\
\hline & {$[40,50)$} & $6(40 \%)$ & $0(0 \%)$ & $9(60 \%)$ & $15(100 \%)$ \\
\hline & {$[50,65)$} & $21(41,17 \%)$ & $4(7,8 \%)$ & $26(51 \%)$ & $51(100 \%)$ \\
\hline & {$[65,75)$} & $40(36 \%)$ & $18(16,21 \%)$ & $53(47,75 \%)$ & $111(100 \%)$ \\
\hline & $\geq 75$ & $49(45,8 \%)$ & $9(8,4 \%)$ & $49(45,8 \%)$ & $107(100 \%)$ \\
\hline \multicolumn{2}{|c|}{ Total } & 117 & 31 & 138 & 286 \\
\hline
\end{tabular}

$(\mathrm{p}<0,05)$ 
No se rechaza la hipótesis de independencia (Razón de verosimilitud 0,282; p valor 0,319). No hay evidencias de que exista una asociación entre el grupo de edad y ser portador de un genotipo específico en este SNP.

\section{Número de paquetes/día}

Tabla 122. Tabla de contingencia según número de paquetes/día y los genotipos de XRCC1

\begin{tabular}{|c|c|c|c|c|c||}
\cline { 3 - 6 } \multicolumn{2}{c|}{} & \multicolumn{3}{c||}{ XRCC1 } & \multirow{2}{*}{ Total } \\
\cline { 2 - 6 } \multicolumn{2}{c|}{} & $\boldsymbol{C} \boldsymbol{C}$ & $\boldsymbol{T} / \boldsymbol{T}$ & $\boldsymbol{C} \boldsymbol{T}$ & \\
\hline \multirow{3}{*}{ Paq./día } & $\leq 1$ & $65(43,62 \%)$ & $13(8,72 \%)$ & $71(47,65 \%)$ & $149(100 \%)$ \\
\cline { 2 - 6 } & $>1$ & $52(37,7 \%)$ & $18(13 \%)$ & $68(49,3 \%)$ & $138(100 \%)$ \\
\hline \multicolumn{2}{|r|}{ Total } & 117 & 31 & 139 & 287 \\
\hline
\end{tabular}

$(\mathrm{p}<0,05)$

No se rechaza la hipótesis de independencia (Chi-cuadrado 1,897; p valor 0,387). No hay evidencias de que exista una asociación entre el número de paquetes fumados al día y ser portador de un genotipo específico en este SNP.

\section{Número de años fumando}

Tabla 123. Tabla de contingencia según número de años fumando y los genotipos de XRCC1

\begin{tabular}{|c|c|c|c|c|c||}
\cline { 3 - 6 } \multicolumn{2}{c|}{} & \multicolumn{3}{c|}{ XRCC1 } & \multirow{2}{*}{ Total } \\
\cline { 3 - 7 } \multicolumn{2}{c|}{} & $\boldsymbol{C} / \boldsymbol{C}$ & $\boldsymbol{T} / \boldsymbol{T}$ & $\boldsymbol{C} \boldsymbol{T}$ & \\
\hline \multirow{2}{*}{$\begin{array}{c}\text { Años } \\
\text { fumando }\end{array}$} & $<38$ años & $38(36,9 \%)$ & $8(7,76 \%)$ & $57(53,34 \%)$ & $103(100 \%)$ \\
\cline { 2 - 6 } & $\geq 38$ años & $79(42,7 \%)$ & $23(12,44 \%)$ & $83(44,86 \%)$ & $185(100 \%)$ \\
\hline \multicolumn{2}{|c|}{ Total } & 117 & 31 & 140 & 288 \\
\hline
\end{tabular}

$(\mathrm{p}<0,05)$

No se rechaza la hipótesis de independencia (Chi-cuadrado 3,381; p valor 0,184). No hay evidencias de que exista una asociación entre el número de años fumados y ser portador de un genotipo específico en este SNP. 


\section{III.- P53 codon 72}

\section{Edad}

Tabla 124. Tabla de contingencia según intervalos de edad y los genotipos del codon 72 de p53

\begin{tabular}{|c|c|c|c|c|c|}
\hline & & \multicolumn{3}{|c|}{ P53 } & \multirow{2}{*}{ Total } \\
\hline & & Arg/Arg & Pro/Pro & Arg/Pro & \\
\hline \multirow{5}{*}{ Edad } & $<40$ & $30(47,6 \%)$ & $8(12,7 \%)$ & $25(39,7 \%)$ & $63(100 \%)$ \\
\hline & {$[40,50)$} & $40(55,55 \%)$ & $6(8,34 \%)$ & $26(36,1 \%)$ & $72(100 \%)$ \\
\hline & {$[50,65)$} & $37(43 \%)$ & $21(24,4 \%)$ & $28(32,6 \%)$ & $86(100 \%)$ \\
\hline & {$[65,75)$} & $72(62,6 \%)$ & $14(12,17 \%)$ & $29(25,23 \%)$ & $115(100 \%)$ \\
\hline & $\geq 75$ & $61(53 \%)$ & $16(14 \%)$ & $38(33 \%)$ & $115(100 \%)$ \\
\hline \multicolumn{2}{|c|}{ Total } & 240 & 65 & 146 & 451 \\
\hline
\end{tabular}

$(\mathrm{p}<0,05)$

No se rechaza la hipótesis de independencia (Chi-cuadrado 15,586; $p$ valor 0,049 ).

Sin embargo estamos al borde de la significación. Estudiamos esta asociación más detalladamente. Para ello particionamos la tabla de contingencia original en 8 tablas de contingencia $2 \times 2$ y cuantificamos la asociación utilizando las odds-ratio correspondientes para determinar en que intervalo de edad se encuentra la asociación.

\section{$\underline{\text { Tabla } 1}$}

Tabla 125. Tabla de contingencia para los genotipos del codon 72 de $553 \mathrm{Arg} / \mathrm{Arg}$ vs Pro/Pro en pacientes menores de 40 vs intervalo de edad de 40-50 años.

\begin{tabular}{|c|c|c|c|c|}
\hline & & \multicolumn{2}{|c|}{ P53 } & \multirow{2}{*}{ Total } \\
\hline & & Arg/Arg & Pro/Pro & \\
\hline \multirow{2}{*}{ Edad } & $<40$ & $30(83,33 \%)$ & $6(16,67 \%)$ & $36(100 \%)$ \\
\hline & {$[40,50)$} & $38(77,55 \%)$ & $11(22,45 \%)$ & $49(100 \%)$ \\
\hline \multicolumn{2}{|c|}{ Total } & 68 & 17 & 85 \\
\hline
\end{tabular}

$(\mathrm{p}<0,05)$ 
No se rechaza la hipótesis de independencia entre las dos variables (Chi-cuadrado $0,434$; $\mathrm{p}$ valor 0,510$)$.

\section{$\underline{\text { Tabla } 2}$}

Tabla 126. Tabla de contingencia para los genotipos del codon 72

de p53 Arg/Arg vs Pro/Pro en pacientes menores de 50 vs intervalo de edad de 50-65 años.

\begin{tabular}{|c|c|c|c|c|}
\hline & & \multicolumn{2}{|c|}{ P53 } & \multirow{2}{*}{ Total } \\
\hline & & Arg/Arg & Pro/Pro & \\
\hline \multirow{2}{*}{ Edad } & $<50$ & $68(79 \%)$ & $18(21 \%)$ & $86(100 \%)$ \\
\hline & {$[50,65)$} & $40(78,44 \%)$ & $11(21,56 \%)$ & $51(100 \%)$ \\
\hline \multicolumn{2}{|c|}{ Total } & 108 & 29 & 137 \\
\hline
\end{tabular}

$(\mathrm{p}<0,05)$

No se rechaza la hipótesis de independencia entre las dos variables (Chi-cuadrado $0,008$; $p$ valor 0,930$)$.

\section{$\underline{\text { Tabla } 3}$}

Tabla 127. Tabla de contingencia para los genotipos del codon 72

de 53 Arg/Arg vs Pro/Pro en pacientes menores de 65 vs intervalo de edad de 65-75 años.

\begin{tabular}{|c|c|c|c|c|}
\hline & & \multicolumn{2}{|c|}{ P53 } & \multirow{2}{*}{ Total } \\
\hline & & Arg/Arg & Pro/Pro & \\
\hline \multirow{2}{*}{ Edad } & $<65$ & $108(78,83 \%)$ & $29(21,17 \%)$ & $137(100 \%)$ \\
\hline & {$[65,75)$} & $67(76,13 \%)$ & $21(23,87 \%)$ & $88(100 \%)$ \\
\hline \multicolumn{2}{|c|}{ Total } & 175 & 50 & 225 \\
\hline
\end{tabular}

$(\mathrm{p}<0,05)$

No se rechaza la hipótesis de independencia entre las dos variables (Chi-cuadrado $0,225$; $p$ valor 0,635$)$. 


\section{Tabla 4}

Tabla 128. Tabla de contingencia para los genotipos del codon 72 de p53 Arg/Arg vs Pro/Pro en pacientes menores de 75 vs $>75$ años.

\begin{tabular}{|c|c|c|c|c|}
\hline & & \multicolumn{2}{|c|}{ P53 } & \multirow{2}{*}{ Total } \\
\hline & & Arg/Arg & Pro/Pro & \\
\hline \multirow{2}{*}{ Edad } & $<75$ & $179(78,5 \%)$ & $49(21,5 \%)$ & $228(100 \%)$ \\
\hline & $\geq 75$ & $61(79,22 \%)$ & $16(20,73 \%)$ & $77(100 \%)$ \\
\hline \multicolumn{2}{|c|}{ Total } & 240 & 65 & 305 \\
\hline
\end{tabular}

$(\mathrm{p}<0,05)$

No se rechaza la hipótesis de independencia entre las dos variables (Chi-cuadrado $0,017$; $p$ valor 0,895$)$.

\section{$\underline{\text { Tabla } 5}$}

Tabla 129. Tabla de contingencia para los genotipos del codon 72 de p53 Homocigotos vs Heterocigotos en pacientes menores de 40 vs intervalo de edad de 40-50 años.

\begin{tabular}{|c|c|c|c|c|}
\cline { 3 - 5 } \multicolumn{2}{|c|}{} & \multicolumn{2}{c|}{ P53 } & \multirow{2}{*}{ Total } \\
\cline { 3 - 5 } \multicolumn{2}{|c|}{} & Homocigoto & Heterocigoto & \\
\hline \multirow{2}{*}{ Edad } & $<40$ & $36(58 \%)$ & $26(42 \%)$ & $62(100 \%)$ \\
\cline { 2 - 5 } & T40,50) & $49(68 \%)$ & $23(32 \%)$ & $72(100 \%)$ \\
\hline \multicolumn{2}{|c|}{ Total } & 85 & 49 & 134 \\
\hline
\end{tabular}

$(\mathrm{p}<0,05)$

No se rechaza la hipótesis de independencia entre las dos variables (Chi-cuadrado 1,434; $\mathrm{p}$ valor 0,231$)$. 


\section{Tabla 6}

Tabla 130. Tabla de contingencia para los genotipos del codon 72 de p53

Homocigotos vs Heterocigotos en pacientes menores de 50 vs intervalo de edad de 50-65 años.

\begin{tabular}{|c|c|c|c|c||}
\cline { 3 - 5 } \multicolumn{2}{c|}{} & \multicolumn{2}{c|}{ P53 } & \multirow{2}{*}{ Total } \\
\cline { 3 - 6 } \multicolumn{2}{c|}{} & Homocigoto & Heterocigoto & \\
\hline \multirow{2}{*}{ Edad } & $<\mathbf{5 0}$ & $86(63,7 \%)$ & $49(36,3 \%)$ & $135(100 \%)$ \\
\cline { 2 - 5 } & $\mathbf{5 0 , 6 5 )}$ & $51(59,3 \%)$ & $35(40,7 \%)$ & $86(100 \%)$ \\
\hline \multicolumn{2}{|c|}{ Total } & 137 & 84 & 221 \\
\hline
\end{tabular}

$(\mathrm{p}>0,05)$

No se rechaza la hipótesis de independencia entre las dos variables (Chi-cuadrado $0,432$; $p$ valor 0,511$)$.

\section{$\underline{\text { Tabla } 7}$}

Tabla 131. Tabla de contingencia para los genotipos del codon 72 de p53

Homocigotos vs Heterocigotos en pacientes menores de 65 vs intervalo de edad de 65-75 años.

\begin{tabular}{|c|c|c|c|c|}
\hline & & \multicolumn{2}{|c|}{$P 53$} & \multirow{2}{*}{ Total } \\
\hline & & Homocigoto & Heterocigoto & \\
\hline \multirow{2}{*}{ Edad } & $<65$ & $137(62 \%)$ & $84(38 \%)$ & $221(100 \%)$ \\
\hline & {$[65,75)$} & $88(76,5 \%)$ & $27(23,5 \%)$ & $115(100 \%)$ \\
\hline Total & & 225 & 111 & 336 \\
\hline
\end{tabular}

$(\mathrm{p}<0,05)$

Se rechaza la hipótesis de independencia entre las dos variables (Chi-cuadrado 7,219; p valor 0,007$)$. 
Tabla 132. Estimación de la Odds-ratio para los genotipos del codon 72 de p53 Homocigotos vs Heterocigotos en pacientes menores de 65 vs intervalo de edad de 65-75 años.

\begin{tabular}{|l|c|c|c|}
\cline { 3 - 4 } \multicolumn{1}{c|}{} & \multirow{2}{*}{ Valor } & \multicolumn{2}{|c|}{ Intervalo de confianza al 95\% } \\
\cline { 3 - 4 } \multicolumn{1}{c|}{} & & Inferior & Superior \\
\hline Odds-ratio para Edad $(<65 / \mathbf{6 5 , 7 5 ) )}$ &, 500 &, 301 &, 833 \\
\hline Para la cohorte P53 = Homocigoto &, 810 &, 701 &, 936 \\
\hline Para la cohorte P53 = Hetocigoto & 1,619 & 1,118 & 2,345 \\
\hline N de casos válidos & 336 & & \\
\hline
\end{tabular}

En la muestra de individuos con edades entre los 65 y los 75 años, es significativamente más frecuente encontrar homocigotos que en la muestra de individuos menores de 65 años.

\section{Tabla 8}

Tabla 133. Tabla de contingencia para los genotipos del codon 72 de p53

Homocigotos vs Heterocigotos en pacientes menores de $<75$ vs $>75$ años.

\begin{tabular}{|c|c|c|c|c||}
\cline { 3 - 5 } \multicolumn{2}{c|}{} & \multicolumn{2}{c|}{ P53 } & \multirow{2}{*}{ Total } \\
\cline { 3 - 5 } \multicolumn{2}{c|}{} & Homocigoto & Heterocigoto & \\
\hline \multirow{2}{*}{ Edad } & $<75$ & $228(67,85 \%)$ & $108(32,15 \%)$ & $336(100 \%)$ \\
\cline { 2 - 5 } & $\geq 75$ & $77(67 \%)$ & $38(33 \%)$ & $115(100 \%)$ \\
\hline \multicolumn{2}{|c|}{ Total } & 305 & 146 & 451 \\
\hline
\end{tabular}

$(\mathrm{p}<0,05)$

No se rechaza la hipótesis de independencia entre las dos variables (Chi-cuadrado $0,032$; p valor 0,859$)$. 


\section{Número de paquetes/día}

Tabla 134. Tabla de contingencia según número de paquetes/día y los genotipos del codon 72 de p53

\begin{tabular}{|c|c|c|c|c|c||}
\cline { 3 - 6 } \multicolumn{1}{c||}{} & \multicolumn{3}{c|}{ P53 } & \multirow{2}{*}{ Total } \\
\cline { 2 - 5 } \multicolumn{1}{c|}{} & Arg/Arg & Pro/Pro & Arg/Pro & \\
\hline \multirow{2}{*}{ Paq./día } & $\leq 1$ & $125(55,44 \%)$ & $37(15,22 \%)$ & $81(33,33 \%)$ & $243(100 \%)$ \\
\cline { 2 - 6 } & $>1$ & $116(55,5 \%)$ & $28(13,4 \%)$ & $65(31,1 \%)$ & $209(100 \%)$ \\
\hline \multicolumn{2}{|c|}{ Total } & 241 & 65 & 146 & 452 \\
\hline
\end{tabular}

$(\mathrm{p}<0,05)$

No se rechaza la hipótesis de independencia (Chi-cuadrado 0,783 ; $\mathrm{p}$ valor 0,676 ). No hay evidencias de que exista una asociación entre el número de paquetes fumados al día y ser portador de un genotipo específico en este SNP.

Número de años fumando

Tabla 135. Tabla de contingencia según número de años fumando $y$ los genotipos del codon 72 de p53

\begin{tabular}{|c|c|c|c|c|c|}
\hline & & \multicolumn{3}{|c|}{ P53 } & \multirow{2}{*}{ Total } \\
\hline & & Arg/Arg & Pro/Pro & Arg/Pro & \\
\hline \multirow{2}{*}{$\begin{array}{c}\text { Años } \\
\text { fumando }\end{array}$} & $<38$ años & $133(54,56 \%)$ & $34(13,43 \%)$ & $86(34 \%)$ & $253(100 \%)$ \\
\hline & $\geq 38$ años & $109(54,5 \%)$ & $31(15,5 \%)$ & $60(30 \%)$ & $200(100 \%)$ \\
\hline \multicolumn{2}{|c|}{ Total } & 242 & 65 & 146 & 453 \\
\hline
\end{tabular}

$(\mathrm{p}<0,05)$

No se rechaza la hipótesis de independencia (Chi-cuadrado 0,961 ; $p$ valor 0,618). No hay evidencias de que exista una asociación entre el número de años fumando y ser portador de un genotipo específico en este SNP. 


\section{IV.-P53 Intron 3}

\section{Edad}

Tabla 136. Tabla de contingencia según intervalos de edad y los genotipos del Intrón 3 de p53

\begin{tabular}{|c|c|c|c|c|c|}
\hline & & \multicolumn{3}{|c|}{ P53 Intron 3} & \multirow{2}{*}{ Total } \\
\hline & & $106 \mathrm{bp}$ & $90 \mathrm{bp}$ & $106+90 b p$ & \\
\hline \multirow{5}{*}{ Edad } & $<40$ & $3(4,76 \%)$ & $42(66,66 \%)$ & $18(28,57 \%)$ & $63(100 \%)$ \\
\hline & {$[40,50)$} & $7(9,72 \%)$ & $49(68,05 \%)$ & $16(22,22 \%)$ & $72(100 \%)$ \\
\hline & {$[50,65)$} & $0(0 \%)$ & $61(71 \%)$ & $25(29 \%)$ & $86(100 \%)$ \\
\hline & {$[65,75)$} & $3(2,6 \%)$ & $76(66,1 \%)$ & $36(31,3 \%)$ & $115(100 \%)$ \\
\hline & $\geq 75$ & $1(0,86 \%)$ & $83(72,17 \%)$ & $31(26,9 \%)$ & $115(100 \%)$ \\
\hline \multicolumn{2}{|c|}{ Total } & 14 & 311 & 126 & 451 \\
\hline
\end{tabular}

$(\mathrm{p}<0,05)$

Se rechaza la hipótesis de independencia entre las dos variables (Razón de verosimilitud 16,$819 ; \mathrm{p}$ valor 0,032 ).

Estudiamos esta asociación más detalladamente. Para ello particionamos la tabla de contingencia original en 8 tablas de contingencia $2 \times 2$ y cuantificamos la asociación utilizando las odds-ratio correspondientes.

\section{$\underline{\text { Tabla } 1}$}

Tabla 137. Tabla de contingencia para los genotipos del Intrón 3 de p53 106bp vs 90 bp en pacientes menores de 40 años vs intervalo de edad de 40-50 años.

\begin{tabular}{|c|c|c|c|c|}
\hline & & \multicolumn{2}{|c|}{ P53 Intron 3} & \multirow[t]{2}{*}{ Total } \\
\hline & & $106 b p$ & $90 b p$ & \\
\hline \multirow{2}{*}{ Edad } & $<40$ & $9(19,2 \%)$ & $38(88,8 \%)$ & $47(100 \%)$ \\
\hline & {$[40,50)$} & $2(3,27 \%)$ & $59(96,72 \%)$ & $61(100 \%)$ \\
\hline \multicolumn{2}{|c|}{ Total } & 11 & 97 & 108 \\
\hline
\end{tabular}

$$
(\mathrm{p}<0,05)
$$

Estudio de los polimorfismos de genes reparadores en población fumadora con y sin cáncer de pulmón 
Se rechaza la hipótesis de independencia entre las dos variables (Razón de verosimilitud 7,$581 ; p$ valor 0,006$)$

Tabla 138. Estimación del riesgo para los genotipos del intrón 3 de p53 106bp vs 90 bp en pacientes menores de 40 vs intervalo de edad de 40-50 años.

\begin{tabular}{|c|c|c|c|}
\hline & \multirow{2}{*}{ Valor } & \multicolumn{2}{|c|}{ Intervalo de confianza al 95\% } \\
\hline & & Inferior & Superior \\
\hline Odds-ratio para Edad $(<40 /[40,50))$ & 6,987 & 1,431 & 34,107 \\
\hline Para la cohorte P53 Intron $3=106 \mathrm{bp}$ & 5,840 & 1,324 & 25,765 \\
\hline Para la cohorte P53 Intron 3=90bp & 836 &, 722 & ,968 \\
\hline$N$ de casos válidos & 108 & & \\
\hline
\end{tabular}

En la muestra de individuos con edades entre los 40 y los 50 años, es significativamente más frecuente encontrar homocigotos del tipo 90bp en lugar de 106bp, que en la muestra de individuos menores de 40 años.

\section{Tabla 2}

Tabla 139. Tabla de contingencia para los genotipos del Intrón 3 de p53 106bp vs 90 bp en pacientes menores de 50 años vs intervalo de edad de 50-65 años.

\begin{tabular}{|c|c|c|c|c|}
\hline & & \multicolumn{2}{|c|}{ P53 Intron 3} & \multirow{2}{*}{ Total } \\
\hline & & $106 b p$ & $90 b p$ & \\
\hline \multirow{2}{*}{ Edad } & $<50$ & $11(10,2 \%)$ & $97(89,8 \%)$ & $108(100 \%)$ \\
\hline & {$[50,65)$} & $0(0 \%)$ & $56(56 \%)$ & $56(100 \%)$ \\
\hline \multicolumn{2}{|c|}{ Total } & 11 & 153 & 164 \\
\hline
\end{tabular}

$(p<0,05)$

Se rechaza la hipótesis de independencia entre las dos variables (Razón de verosimilitud 9,596; $p$ valor 0,002 ) 
Tabla 140. Estimación del riesgo para los genotipos del intrón 3 de p53 106bp vs 90 bp en pacientes menores de 40 vs intervalo de edad de 50-65 años.

\begin{tabular}{|l|c|c|c|}
\cline { 3 - 4 } \multicolumn{1}{c|}{} & \multirow{2}{*}{ Valor } & \multicolumn{2}{|c|}{ Intervalo de confianza al 95\% } \\
\cline { 3 - 4 } \multicolumn{1}{c|}{} & & Inferior & Superior \\
\hline Para la cohorte P53 Intron 3=90bp &, 898 &, 843 &, 957 \\
\hline N de casos válidos & 164 & & \\
\hline
\end{tabular}

No hay individuos portadores de 106bp en la muestra de individuos con edades entre los 50 y los 65 años.

\section{Tabla 3}

Tabla 141. Tabla de contingencia para los genotipos del Intrón 3 de p53 106bp vs 90 bp en pacientes menores de 65 años vs intervalo de edad de 65-75 años.

\begin{tabular}{|c|c|c|c|c|}
\cline { 3 - 5 } \multicolumn{2}{c|}{} & \multicolumn{2}{c|}{ P53 Intron 3 } & \multirow{2}{*}{ Total } \\
\cline { 3 - 5 } \multicolumn{2}{c|}{} & $\mathbf{1 0 6 b p}$ & $\mathbf{9 0 b p}$ & \\
\hline \multirow{2}{*}{ Edad } & $<65$ & $11(6,7 \%)$ & $153(93,3 \%)$ & $164(100 \%)$ \\
\cline { 2 - 5 } & $\mathbf{I 6 5 , 7 5 )}$ & $4(4,87 \%)$ & $78(95,13 \%)$ & $82(100 \%)$ \\
\hline \multicolumn{2}{|c|}{ Total } & 15 & 231 & 246 \\
\hline
\end{tabular}

$(\mathrm{p}<0,05)$

No se rechaza la hipótesis de independencia entre las dos variables. (Chi-cuadrado 0,$319 ; \mathrm{p}$ valor 0,572 )

\section{Tabla 4}

Tabla 142. Tabla de contingencia para los genotipos del Intrón 3 de p53 106bp vs 90 bp en pacientes menores de 75 años vs $>75$ años.

\begin{tabular}{|c|c|c|c|c||}
\cline { 3 - 5 } \multicolumn{2}{c|}{} & \multicolumn{2}{c||}{ P53 Intron 3 } & \multirow{2}{*}{ Total } \\
\cline { 3 - 5 } \multicolumn{2}{c|}{} & \multicolumn{1}{c|}{$\mathbf{1 0 6 b p}$} & $\mathbf{9 0 b p}$ & \\
\hline \hline \multirow{2}{*}{ Edad } & $<75$ & $13(5,4 \%)$ & $228(94,6 \%)$ & $241(100 \%)$ \\
\cline { 2 - 5 } & & $1(1,2 \%)$ & $83(98,8 \%)$ & $84(100 \%)$ \\
\hline \multicolumn{2}{|c|}{ Total } & 14 & 311 & 325 \\
\hline
\end{tabular}

$$
(\mathrm{p}<0,05)
$$

Estudio de los polimorfismos de genes reparadores en población fumadora con y sin cáncer de pulmón 
No se rechaza la hipótesis de independencia entre las dos variables. (Razón de verosimilitud 3,$390 ; p$ valor 0,066 )

\section{$\underline{\text { Tabla } 5}$}

Tabla 143. Tabla de contingencia para los genotipos del intrón 3 de p53

Homocigotos vs Heterocigotos en pacientes menores de 40 vs intervalo de edad de 40-50 años.

\begin{tabular}{|c|c|c|c|c|}
\hline & & \multicolumn{2}{|c|}{ P53 Intron 3} & \multirow{2}{*}{ Total } \\
\hline & & Homocigoto & Heterocigoto & \\
\hline \multirow{2}{*}{ Edad } & $<40$ & $47(75,8 \%)$ & $15(24,2 \%)$ & $62(100 \%)$ \\
\hline & {$[40,50)$} & $61(84,7 \%)$ & $11(15,3 \%)$ & $72(100 \%)$ \\
\hline \multicolumn{2}{|c|}{ Total } & 108 & 26 & 134 \\
\hline
\end{tabular}

$(\mathrm{p}<0,05)$

No se rechaza la hipótesis de independencia entre las dos variables. (Chi-cuadrado 1,693 ; p valor 0,193 )

\section{Tabla 6}

Tabla 144. Tabla de contingencia para los genotipos del intrón 3 de p53

Homocigotos vs Heterocigotos en pacientes menores de 50 vs intervalo de edad de 50-65 años.

\begin{tabular}{|c|c|c|c|c|}
\hline & & \multicolumn{2}{|c|}{ P53 Intron 3} & \multirow{2}{*}{ Total } \\
\hline & & Homocigoto & Heterocigoto & \\
\hline \multirow{2}{*}{ Edad } & $<50$ & $108(80 \%)$ & $27(20 \%)$ & $135(100 \%)$ \\
\hline & {$[50,65)$} & $56(65 \%)$ & $30(35 \%)$ & $86(100 \%)$ \\
\hline \multicolumn{2}{|c|}{ Total } & 164 & 57 & 221 \\
\hline
\end{tabular}

$(\mathrm{p}<0,05)$

Se rechaza la hipótesis de independencia entre las dos variables (Chi-cuadrado 6,080; p valor 0,014). 
Tabla 145. Estimación del riesgo para los genotipos del intrón 3 de p53 Homocigotos vs Heterocigotos en pacientes menores de 50 vs intervalo de edad de 50-65 años.

\begin{tabular}{|l|c|c|c||}
\cline { 3 - 4 } \multicolumn{1}{l|}{} & \multirow{2}{*}{ Valor } & \multicolumn{2}{c|}{ Intervalo de confianza al 95\% } \\
\cline { 3 - 4 } & & Inferior & Superior \\
\hline \hline Odds-ratio para Edad (<50 / [50,65)) & 2,143 & 1,162 & 3,952 \\
\hline Para la cohorte P53 Intron 3= Homocigoto & 1,229 & 1,030 & 1,465 \\
\hline Para la cohorte P53 Intron 3= Heterocigoto &, 573 &, 368 &, 894 \\
\hline N de casos válidos & 221 & & \\
\hline
\end{tabular}

En la muestra de individuos menores de 50 años, es significativamente más frecuente encontrar homocigotos, que en la muestra de individuos cuya edad este en el intervalo 50-65 años.

\section{$\underline{\text { Tabla } 7}$}

Tabla 146. Tabla de contingencia para los genotipos del intrón 3 de p53 Homocigotos vs Heterocigotos en pacientes menores de 65 vs intervalo de edad de 65-75 años.

\begin{tabular}{||c|c|c|c|c||}
\cline { 3 - 4 } \multicolumn{2}{|c|}{} & \multicolumn{2}{c|}{ P53 Intron 3 } & \multirow{2}{*}{ Total } \\
\cline { 3 - 4 } \multicolumn{2}{|c|}{} & Homocigoto & Heterocigoto & \\
\hline \hline \multirow{2}{*}{ Edad } & $<\mathbf{6 5}$ & $164(74,2 \%)$ & $57(25,8 \%)$ & $221(100 \%)$ \\
\cline { 2 - 5 } & $\mathbf{I 6 5 , 7 5 )}$ & $82(71,3 \%)$ & $33(28,7 \%)$ & $115(100 \%)$ \\
\hline \multicolumn{2}{|c|}{ Total } & 246 & 90 & 336 \\
\hline
\end{tabular}

$(\mathrm{p}<0,05)$

No se rechaza la hipótesis de independencia entre las dos variables (Chi-cuadrado $0,325$; $\mathrm{p}$ valor 0,568$)$. 


\section{Tabla 8}

Tabla 147. Tabla de contingencia para los genotipos del intrón 3 de p53 Homocigotos vs Heterocigotos en pacientes menores de 75 vs $>75$ años.

\begin{tabular}{|c|c|c|c|c|}
\hline & & \multicolumn{2}{|c|}{ P53 Intron 3} & \multirow{2}{*}{ Total } \\
\hline & & Homocigoto & Heterocigoto & \\
\hline \multirow{2}{*}{ Edad } & $<75$ & $241(71,7 \%)$ & $95(28,3 \%)$ & $336(100 \%)$ \\
\hline & $\geq 75$ & $84(73 \%)$ & $31(27 \%)$ & $115(100 \%)$ \\
\hline \multicolumn{2}{|c|}{ Total } & 325 & 126 & 451 \\
\hline
\end{tabular}

$(\mathrm{p}<0,05)$

No se rechaza la hipótesis de independencia entre las dos variables (Chi-cuadrado 0,074; p valor 0,786$)$.

Número de paquetes/día

Tabla 148. Tabla de contingencia según número de paquetes/día y los genotipos del Intrón 3 de p53

\begin{tabular}{|c||c|c|c|c|c||}
\cline { 2 - 5 } \multicolumn{1}{|c|}{} & \multicolumn{4}{c||}{ P53 Intron 3 } & \multirow{2}{*}{ Total } \\
\cline { 2 - 6 } & $\mathbf{1 0 6 b p}$ & $\mathbf{9 0 b p}$ & $\mathbf{1 0 6 + 9 0 b p}$ & \\
\hline \multirow{2}{*}{ Paq./día } & $\leq 1$ & $10(4,1 \%)$ & $\begin{array}{c}164 \\
(67,5 \%)\end{array}$ & $69(28,4 \%)$ & $243(100 \%)$ \\
\cline { 2 - 6 } & $>1$ & $4(1,9 \%)$ & $\begin{array}{c}148 \\
(70,8 \%)\end{array}$ & $57(27,3 \%)$ & $209(100 \%)$ \\
\hline \multicolumn{2}{|c|}{ Total } & 14 & 312 & 126 & 452 \\
\hline
\end{tabular}

$(\mathrm{p}<0,05)$

Tabla 149. Tests de asociación

\begin{tabular}{||c|c|c|c|}
\cline { 2 - 4 } \multicolumn{1}{c|}{} & Valor & gl & Sig. asintótica (bilateral) \\
\hline Chi-cuadrado de Pearson & $1,989(\mathrm{a})$ & 2 &, 370 \\
\hline Razón de verosimilitud & 2,062 & 2 &, 357 \\
\hline $\boldsymbol{N}$ de casos válidos & 452 & & \\
\hline \hline
\end{tabular}

(a) 0 casillas (,0\%) tienen una frecuencia esperada inferior a 5. La frecuencia mínima esperada es 6,47. 
No se rechaza la hipótesis de independencia entre las dos variables (Chi-cuadrado 1,989; $p$ valor 0,370$)$. No hay evidencias de que exista una asociación entre el número de paquetes fumados al día y ser portador de un genotipo específico en este SNP.

Número de años fumando

Tabla 150. Tabla de contingencia según número de años fumando para el Intrón 3 de p53

\begin{tabular}{|c|c|c|c|c|c|}
\hline & \multicolumn{3}{|c|}{ P53 Intron 3} & \multirow{2}{*}{ Total } \\
\hline & & $106 b p$ & $90 b p$ & $106+90 b p$ & \\
\hline \multirow{2}{*}{$\begin{array}{c}\text { Años } \\
\text { fumando }\end{array}$} & $<38$ años & $11(4,4 \%)$ & $172(68 \%)$ & $70(27,6 \%)$ & $253(100 \%)$ \\
\hline & $\geq 38$ años & $3(1,5 \%)$ & $\begin{array}{c}141 \\
(70,5 \%)\end{array}$ & $56(28 \%)$ & $200(100 \%)$ \\
\hline \multicolumn{2}{|c|}{ Total } & 14 & 313 & 126 & 453 \\
\hline
\end{tabular}

$(\mathrm{p}<0,05)$

Tabla 151. Tests de asociación

\begin{tabular}{|l|c|c|c||}
\cline { 2 - 4 } \multicolumn{1}{c|}{} & Valor & $\boldsymbol{g l}$ & Sig. asintótica (bilateral) \\
\hline \hline Chi-cuadrado de Pearson & $3,038(\mathrm{a})$ & 2 &, 219 \\
\hline Razón de verosimilitud & 3,279 & 2 &, 194 \\
\hline N de casos válidos & 453 & & \\
\hline
\end{tabular}

(a) 0 casillas (,0\%) tienen una frecuencia esperada inferior a 5. La frecuencia mínima esperada es 6,18.

No se rechaza la hipótesis de independencia entre las dos variables (Chi-cuadrado 3,038; $p$ valor 0,219). No hay evidencias de que exista una asociación entre el número de años fumados y ser portador de un genotipo específico en este SNP.

\subsubsection{2.- RIESGO DE PADECER CANCER CONSIDERANDO ESTAS VARIABLES}

Planteamos modelos de regresión logística que intenten explicar el riesgo que tiene un individuo de desarrollar cáncer de pulmón en función de cada SNP junto con cada una de estas variables no genéticas. En primer lugar planteamos el modelo en el 
que intervienen como variables explicativas el SNP, cada una de estas variables no genéticas y su interacción. Posteriormente utilizamos el procedimiento stepwise para elegir el modelo que mejor se ajusta utilizando todas las variables a la vez.

\section{I.- ERCC1}

\section{Edad}

Tabla 152. Ajuste de el modelo de regresión logística en función de ERCC1 y la Edad

\begin{tabular}{|c|c|c|c|c|c|c|c|c|}
\hline & \multirow[t]{2}{*}{$\beta$} & \multirow{2}{*}{ E.T. } & \multirow{2}{*}{ Wald } & \multirow{2}{*}{$g l$} & \multirow{2}{*}{ Sig. } & \multirow{2}{*}{ O.R. } & \multicolumn{2}{|c|}{$\begin{array}{l}\text { I.C. } 95,0 \% \\
\text { para O.R. }\end{array}$} \\
\hline & & & & & & & Inf. & Sup. \\
\hline ERCC1 & & & 4,343 & 2 &, 114 & & & \\
\hline $\operatorname{ERCC1(1)}$ & 1,053 &, 520 & 4,095 & 1 &, 043 & 2,867 & 1,034 & 7,950 \\
\hline $\operatorname{ERCC1}(2)$ & ,940 & ,670 & 1,965 & 1 &, 161 & 2,560 & ,688 & 9,524 \\
\hline Edad & & & 12,071 & 4 &, 017 & & & \\
\hline $\operatorname{Edad}(1)$ & 23,018 & 40193 &, 000 & 1 & 1,000 & $>>$ &, 000 & . \\
\hline $\operatorname{Edad}(2)$ & 23,018 & 17974,8 & 000 & 1 & ,999 & $>>$ &, 000 & . \\
\hline Edad(3) & 23,018 & 7463,65 &, 000 & 1 & ,998 & $>>$ &, 000 & . \\
\hline $\operatorname{Edad}(4)$ & 1,769 & ,509 & 12,071 & 1 &, 001 & 5,864 & 2,162 & $\begin{array}{c}15,90 \\
4\end{array}$ \\
\hline ERCC1 by Edad & & & 4,133 & 7 & ,764 & & & \\
\hline ERCC1(1) by Edad (1) & $-1,053$ & 56841,4 & ,000 & 1 & 1,000 & ,349 &, 000 & . \\
\hline ERCC1(1) by Edad (2) & $-1,053$ & 22913,5 &, 000 & 1 & 1,000 & ,349 &, 000 & . \\
\hline ERCC1(1) by Edad (3) & $-1,053$ & 12277,4 &, 000 & 1 & 1,000 & ,349 &, 000 & . \\
\hline ERCC1(1) by Edad (4) & $-1,317$ & 665 & 3,916 & 1 &, 048 & ,268 &, 073 & ,987 \\
\hline ERCC1(2) by Edad (2) &,- 940 & 33627,9 &, 000 & 1 & 1,000 & ,391 &, 000 & . \\
\hline ERCC1(2) by Edad (3) &,- 940 & 24376,2 &, 000 & 1 & 1,000 &, 391 &, 000 & . \\
\hline ERCC1(2) by Edad (4) & $-1,145$ & ,892 & 1,645 & 1 & ,200 & ,318 &, 055 & 1,830 \\
\hline Constante & $-1,815$ & ,408 & 19,838 & 1 &, 000 &, 163 & & \\
\hline
\end{tabular}


El único caso en el que el TRV es significativo es en la variable edad (chicuadrado 12,071; $\mathrm{p}$-valor $=0,017)$, es decir que rechazamos que individuos pertenecientes a distintos grupos de edad tengan el mismo riesgo de padecer cáncer de pulmón. El único coeficiente significativo es el correspondiente al grupo de edad $[65,75)$, en el que la OR correspondiente es $>1$, es decir que individuos pertenecientes a este grupo de edad tienen más riesgo de padecer cáncer de pulmón.

\section{Número de paquetes/día}

Tabla 153. Ajuste del modelo de regresión logística en función de ERCC1 y el número de paquetes/día.

\begin{tabular}{|c|c|c|c|c|c|c|c|c|}
\hline & \multirow[t]{2}{*}{$\beta$} & \multirow[t]{2}{*}{ E.T. } & \multirow[t]{2}{*}{ Wald } & \multirow[t]{2}{*}{$g l$} & \multirow[t]{2}{*}{ Sig. } & \multirow[t]{2}{*}{$O . R$. } & \multicolumn{2}{|c|}{$\begin{array}{l}\text { I.C. } 95,0 \% \\
\text { para } O . R .\end{array}$} \\
\hline & & & & & & & Inf. & Sup. \\
\hline ERCC1 & & & 4,041 & 2 & ,133 & & & \\
\hline $\operatorname{ERCC1(1)}$ &, 221 & ,371 & ,354 & 1 &, 552 & 1,247 & ,602 & 2,584 \\
\hline $\operatorname{ERCC1(2)}$ &,- 932 & ,569 & 2,680 & 1 &, 102 & ,394 & ,129 & 1,202 \\
\hline Paquetes / día (1) &,- 731 & ,361 & 4,098 & 1 &, 043 & ,481 & ,237 & ,977 \\
\hline ERCC1 by Paq & & & 5,455 & 2 &, 065 & & & \\
\hline ERCC1(1) by Paq(1) &,- 234 & ,518 & ,205 & 1 &, 651 & ,791 &, 287 & 2,184 \\
\hline ERCC1(2) by Paq(1) & 1,519 & ,756 & 4,041 & 1 &, 044 & 4,569 & 1,039 & 20,099 \\
\hline Constante &, 325 & 257 & 1,599 & 1 & ,206 & 1,385 & & \\
\hline
\end{tabular}

La única variable que resulta significativa es el número de paquetes al día que se fuma. La OR es $<1$, es decir que fumar más de un paquete al día es un factor de riesgo. 


\section{Número de años fumando}

Tabla 154. Ajuste de el modelo de regresión logística en función de ERCC1 y el número de años fumando

\begin{tabular}{|c|c|c|c|c|c|c|c|c|}
\hline & \multirow[t]{2}{*}{$\beta$} & \multirow[t]{2}{*}{ E.T. } & \multirow[t]{2}{*}{ Wald } & \multirow[t]{2}{*}{$g l$} & \multirow[t]{2}{*}{ Sig. } & \multirow[t]{2}{*}{$O . R}$. & \multicolumn{2}{|c|}{$\begin{array}{l}\text { I.C. } 95,0 \% \\
\text { para O.R. }\end{array}$} \\
\hline & & & & & & & Inf. & Sup. \\
\hline ERCC1 & & & ,436 & 2 &, 804 & & & \\
\hline $\operatorname{ERCC1(1)}$ &, 138 &, 317 &, 191 & 1 & ,662 & 1,148 &, 617 & 2,136 \\
\hline $\operatorname{ERCC1}(2)$ &,- 149 & ,475 & ,099 & 1 &, 753 &, 861 &, 340 & 2,184 \\
\hline NAños (1) & $\begin{array}{c}1,08 \\
7 \\
\end{array}$ & ,383 & 8,076 & 1 &, 004 & 2,967 & 1,401 & 6,280 \\
\hline ERCC1 by NAños & & & ,009 & 2 & 995 & & & \\
\hline ERCC1(1) by NAños(1) &, 011 &, 562 &, 000 & 1 & ,985 & 1,011 & ,336 & 3,039 \\
\hline ERCC1(2) by NAños(1) &, 076 & ,794 & ,009 & 1 & ,924 & 1,079 &, 227 & 5,118 \\
\hline Constante &,- 426 & ,227 & 3,514 & 1 &, 061 & ,653 & & \\
\hline
\end{tabular}

La única variable que resulta significativa es el número de años fumando. La OR es $>1$, es decir que haber fumado más de 38 años es un factor de riesgo. 


\section{General}

El modelo de regresión logística ajustado al aplicar el procedimiento stepwise tras 6 pasos se muestra en la siguiente tabla.

Tabla 155. Ajuste del modelo de regresión logística a partir de la introducción/eliminación progresiva de las variables genotipos en ERCC1, Edad, Número de paquetes/día y Número de años fumando.

\begin{tabular}{|c|c|c|c|c|c|c|c|c|}
\hline & \multirow[t]{2}{*}{$\beta$} & \multirow[t]{2}{*}{ E.T. } & \multirow[t]{2}{*}{ Wald } & \multirow[t]{2}{*}{$g l$} & \multirow[t]{2}{*}{ Sig. } & \multirow[t]{2}{*}{ O.R. } & \multicolumn{2}{|c|}{$\begin{array}{r}\text { I.C. } 95,0 \% \\
\text { para } O . R .\end{array}$} \\
\hline & & & & & & & Inf. & Sup. \\
\hline Edad & & & 11,354 & 4 &, 023 & & & \\
\hline $\operatorname{Edad}(1)$ & 10,387 & 70,450 & ,022 & 1 &, 883 & 32444,6 &, 000 & $>>$ \\
\hline $\operatorname{Edad}(2)$ & 10,387 & 25,725 & , 163 & 1 & ,686 & 32444,6 &, 000 & $>>$ \\
\hline $\operatorname{Edad}(3)$ & 10,387 & 14,235 & ,532 & 1 & ,466 & 32444,6 &, 000 & $>>$ \\
\hline $\operatorname{Edad}(4)$ & ,966 & ,295 & 10,711 & 1 & ,001 & 2,626 & 1,473 & 4,682 \\
\hline Constante & $-1,185$ & ,224 & 27,937 & 1 &, 000 & ,306 & & \\
\hline
\end{tabular}

La única variable que interviene es la edad y la única OR significativamente distinta de 1 es la correspondiente al intervalo de edad [65,75], siendo $>1$. Es decir que individuos pertenecientes a este grupo de edad tienen más riesgo de padecer cáncer de pulmón. 


\section{II.- XRCC1}

\section{Edad}

Tabla 156. Ajuste de el modelo de regresión logística en función de XRCC1 y la Edad

\begin{tabular}{|c|c|c|c|c|c|c|c|c|}
\hline & \multirow[t]{2}{*}{$\beta$} & \multirow[t]{2}{*}{ E.T. } & \multirow[t]{2}{*}{ Wald } & \multirow[t]{2}{*}{$g l$} & \multirow[t]{2}{*}{ Sig. } & \multirow[t]{2}{*}{$O . R}$. & \multicolumn{2}{|c|}{$\begin{array}{l}\text { I.C. } 95,0 \% \\
\text { para } O . R .\end{array}$} \\
\hline & & & & & & & Inf. & Sup. \\
\hline$X R C C 1$ & & &, 518 & 2 & ,772 & & & \\
\hline$X R C C 1(1)$ &,- 342 & ,480 & ,509 & 1 & ,476 &, 710 & ,277 & 1,819 \\
\hline$X R C C 1(2)$ &,- 234 & ,865 &, 073 & 1 & ,786 &, 791 &, 145 & 4,308 \\
\hline Edad & & & 3,123 & 4 &, 538 & & & \\
\hline $\operatorname{Edad}(1)$ & $\begin{array}{c}22,22 \\
1 \\
\end{array}$ & 40192,97 & ,000 & 1 & 1,000 & $>>$ &, 000 & . \\
\hline $\operatorname{Edad}(2)$ & $\begin{array}{c}22,22 \\
1\end{array}$ & 13397,66 &, 000 & 1 & ,999 & $>>$ &, 000 & . \\
\hline $\operatorname{Edad}(3)$ & $\begin{array}{c}22,22 \\
1 \\
\end{array}$ & 7882,490 &, 000 & 1 & ,998 & $>>$ &, 000 & . \\
\hline $\operatorname{Edad}(4)$ &, 753 & ,426 & 3,123 & 1 & 077 & 2,123 & 921 & 4,893 \\
\hline XRCC1 by Edad & & & ,910 & 6 & ,989 & & & \\
\hline XRCC1(1) by Edad(1) &, 342 & 56841,44 &, 000 & 1 & 1,000 & 1,408 &, 000 & . \\
\hline XRCC1(1) by Edad(2) & ,342 & 21183,56 &, 000 & 1 & 1,000 & 1,408 &, 000 & . \\
\hline XRCC1(1) by Edad(3) &, 342 & 11792,41 &, 000 & 1 & 1,000 & 1,408 &, 000 & . \\
\hline XRCC1(1) by Edad(4) & ,306 & ,640 & ,228 & 1 & ,633 & 1,358 & ,387 & 4,759 \\
\hline XRCC1(2) by Edad(3) &, 234 & 21587,09 & 000 & 1 & 1,000 & 1,264 &, 000 & . \\
\hline XRCC1(2) by Edad(4) &, 952 & 1,029 &, 856 & 1 &, 355 & 2,591 &, 345 & 19,453 \\
\hline Constante & $-1,019$ &, 324 & 9,909 & 1 & 002 & ,361 & & \\
\hline
\end{tabular}

Ninguna de las variables resulta significativa. 


\section{Número de paquetes/día}

Tabla 157. Ajuste de el modelo de regresión logística en función de XRCC1 y el número de paquetes/día

\begin{tabular}{|c|c|c|c|c|c|c|c|c|}
\hline & \multirow[t]{2}{*}{$\beta$} & \multirow[t]{2}{*}{ E.T. } & \multirow[t]{2}{*}{ Wald } & \multirow[t]{2}{*}{$g l$} & \multirow[t]{2}{*}{ Sig. } & \multirow[t]{2}{*}{$O . R}$. & \multicolumn{2}{|c|}{$\begin{array}{l}\text { I.C. } 95,0 \% \text { para } \\
\text { O.R. }\end{array}$} \\
\hline & & & & & & & Inf. & Sup. \\
\hline$X R C C 1$ & & & ,539 & 2 & ,764 & & & \\
\hline$X R C C 1(1)$ &, 014 &, 373 &, 001 & 1 & ,970 & 1,014 & ,488 & 2,105 \\
\hline$X R C C 1(2)$ & ,397 &, 557 & ,508 & 1 & ,476 & 1,487 & 499 & 4,429 \\
\hline Paquetes / día (1) &,- 381 &, 341 & 1,244 & 1 & ,265 & ,683 & ,350 & 1,334 \\
\hline XRCC1 by Paq & & & 1,182 & 2 &, 554 & & & \\
\hline$X R C C 1(1)$ by Paq(1) &,- 399 &, 510 & 612 & 1 & ,434 & 671 & ,247 & 1,823 \\
\hline$X R C C 1(2)$ by $P a q(1)$ &,- 782 &, 832 & 885 & 1 &, 347 & ,457 & ,090 & 2,334 \\
\hline Constante & ,296 & ,245 & 1,460 & 1 & ,227 & 1,345 & & \\
\hline
\end{tabular}

Ninguna variable resulta estadísticamente significativa.

Número de años fumando

Tabla 158. Ajuste del modelo de regresión logística en función de XRCCI y el número de años fumando.

\begin{tabular}{|c|c|c|c|c|c|c|c|c|}
\hline & \multirow[t]{2}{*}{$\beta$} & \multirow[t]{2}{*}{ E.T. } & \multirow{2}{*}{ Wald } & \multirow[t]{2}{*}{$g l$} & \multirow[t]{2}{*}{ Sig. } & \multirow[t]{2}{*}{ O.R. } & \multicolumn{2}{|c|}{$\begin{array}{l}\text { I.C. } 95,0 \% \\
\text { para } O . R .\end{array}$} \\
\hline & & & & & & & Inf. & Sup. \\
\hline$X R C C 1$ & & & 1,360 & 2 &, 507 & & & \\
\hline$X R C C 1(1)$ & ,134 & ,321 & , 174 & 1 & ,676 & 1,143 & 610 & 2,144 \\
\hline$X R C C 1(2)$ &, 553 & ,474 & 1,359 & 1 & ,244 & 1,739 & ,686 & 4,406 \\
\hline NAños (1) & 1,496 & ,376 & 15,829 & 1 &, 000 & 4,462 & 2,136 & 9,324 \\
\hline XRCC1 by NAños & & & 2,953 & 2 & ,228 & & & \\
\hline XRCC1(1) by NAños(1) &,- 845 & ,549 & 2,370 & 1 &, 124 & ,430 &, 146 & 1,260 \\
\hline XRCC1(2) by NAños(1) & $-1,072$ & ,921 & 1,353 & 1 & ,245 & ,342 & 056 & 2,083 \\
\hline Constante &,- 466 & ,226 & 4,272 & 1 & 039 & ,627 & & \\
\hline
\end{tabular}


La única variable que resulta significativa es el número de años fumando. La OR es $>1$, es decir que haber fumado más de 38 años es un factor de riesgo.

\section{General}

El modelo de regresión logística ajustado al aplicar el procedimiento stepwise tras 7 pasos se muestra en la siguiente tabla.

Tabla 159. Ajuste del modelo de regresión logística a partir de la introducción/eliminación progresiva de las variables genotipos en XRCC1, Edad, $N^{o}$ de paquetes/día y $N^{o}$ de años fumando.

\begin{tabular}{|c|c|c|c|c|c|c|c|c|}
\hline & \multirow[t]{2}{*}{$\beta$} & \multirow[t]{2}{*}{ E.T. } & \multirow[t]{2}{*}{ Wald } & \multirow[t]{2}{*}{$g l$} & \multirow[t]{2}{*}{ Sig. } & \multirow[t]{2}{*}{ O.R. } & \multicolumn{2}{|c|}{$\begin{array}{l}\text { I.C. } 95,0 \% \\
\text { para } O . R .\end{array}$} \\
\hline & & & & & & & Inf. & Sup. \\
\hline Edad & & & 12,036 & 4 &, 017 & & & \\
\hline Edad (1) & 10,391 & 70,450 &, 022 & 1 &, 883 & $\begin{array}{l}32551 \\
5\end{array}$ &, 000 & $>>$ \\
\hline Edad (2) & 10,391 & 25,726 &, 163 & 1 & ,686 & $\begin{array}{l}32551 \\
5\end{array}$ &, 000 & $>>$ \\
\hline Edad (3) & 10,391 & 13,953 &, 555 & 1 &, 456 & $\begin{array}{c}32551 \\
5\end{array}$ &, 000 & $>>$ \\
\hline Edad (4) & 1,006 & ,298 & 11,378 & 1 &, 001 & 2,733 & 1,524 & 4,903 \\
\hline Constante & $-1,188$ & ,228 & 27,033 & 1 &, 000 &, 305 & & \\
\hline
\end{tabular}

La única variable que interviene es la edad y la única OR significativamente distinta de 1 es la correspondiente al intervalo de edad [65,75), siendo $>1$. Es decir que individuos pertenecientes a este grupo de edad tienen más riesgo de padecer cáncer de pulmón. 


\section{III.- P53 codon 72}

\section{Edad}

Tabla 160. Ajuste del modelo de regresión logística en función del codon 72 de p53 y la Edad

\begin{tabular}{|c|c|c|c|c|c|c|c|c|}
\hline & \multirow[t]{2}{*}{$\beta$} & \multirow{2}{*}{ E.T. } & \multirow{2}{*}{ Wald } & \multirow[t]{2}{*}{$g l$} & \multirow{2}{*}{ Sig. } & \multirow{2}{*}{$O . R}$. & \multicolumn{2}{|c|}{$\begin{array}{c}\text { I.C. } 95,0 \% \\
\text { para O.R. }\end{array}$} \\
\hline & & & & & & & Inf. & Sup. \\
\hline$P 53$ & & & 1,051 & 2 &, 591 & & & \\
\hline P53(1) & 277 & ,518 & ,286 & 1 &, 592 & 1,319 & ,478 & 3,637 \\
\hline P53(2) &, 700 & 683 & 1,050 & 1 & ,305 & 2,013 &, 528 & 7,672 \\
\hline Edad & & & 20,235 & 4 &, 000 & & & \\
\hline $\operatorname{Edad}(1)$ & $-1,690$ & 1,103 & 2,347 & 1 & ,126 &, 185 & ,021 & 1,603 \\
\hline $\operatorname{Edad}(2)$ &,- 997 & 847 & 1,386 & 1 & ,239 & ,369 &, 070 & 1,940 \\
\hline Edad(3) & 1,345 &, 565 & 5,676 & 1 & 017 & 3,838 & 1,269 & 11,605 \\
\hline $\operatorname{Edad}(4)$ & 1,419 & ,560 & 6,430 & 1 &, 011 & 4,133 & 1,380 & 12,379 \\
\hline P53 by Edad & & & 4,904 & 8 & ,768 & & & \\
\hline P53(1) by Edad(1) & $-18,302$ & 7338,199 &, 000 & 1 & ,998 &, 000 &, 000 & . \\
\hline P53(1) by Edad(2) & 1,109 & ,971 & 1,305 & 1 & ,253 & 3,032 &, 452 & 20,336 \\
\hline P53(1) by Edad(3) & ,249 &, 724 &, 119 & 1 & ,731 & 1,283 & ,311 & 5,298 \\
\hline P53(1) by Edad(4) &,- 602 & 681 & ,781 & 1 & ,377 &, 548 &, 144 & 2,081 \\
\hline P53(2) by Edad(1) & ,533 & 1,628 & ,107 & 1 & ,744 & 1,703 &, 070 & 41,407 \\
\hline P53(2) by Edad(2) & 1,785 & 1,294 & 1,904 & 1 &, 168 & 5,961 & ,472 & 75,296 \\
\hline P53(2) by Edad(3) & ,607 & ,934 & ,422 & 1 &, 516 & 1,834 & ,294 & 11,438 \\
\hline P53(2) by Edad(4) & ,286 & 977 &, 086 & 1 &, 770 & 1,331 & ,196 & 9,026 \\
\hline Constante & $-1,488$ & 418 & 12,645 & 1 &, 000 & 226 & & \\
\hline
\end{tabular}

El único caso en el que el TRV es significativo es en la variable edad (chicuadrado 20,235; p-valor < 0,001), es decir que rechazamos que individuos pertenecientes a distintos grupos de edad tengan el mismo riesgo de padecer cáncer de pulmón. Son significativos los coeficientes correspondientes a los grupos de edad $[50,65)$ y $[65,75)$. En ambos casos la OR es $>1$, es decir que individuos pertenecientes a estos grupos de edad tienen más riesgo de padecer cáncer de pulmón. 


\section{Número de paquetes/día}

Tabla 161. Ajuste del modelo de regresión logística en función del codon 72 de p53 y el número de paquetes/día.

\begin{tabular}{|c|c|c|c|c|c|c|c|c|}
\hline & \multirow[t]{2}{*}{$\beta$} & \multirow[t]{2}{*}{ E.T. } & \multirow[t]{2}{*}{ Wald } & \multirow[t]{2}{*}{$g l$} & \multirow[t]{2}{*}{ Sig. } & \multirow[t]{2}{*}{ O.R. } & \multicolumn{2}{|c|}{$\begin{array}{l}\text { I.C. } 95,0 \% \\
\text { para } 0 . R .\end{array}$} \\
\hline & & & & & & & Inf. & Sup. \\
\hline P53 & & & 13,237 & 2 &, 001 & & & \\
\hline P53(1) & ,392 &, 333 & 1,383 & 1 & ,240 & 1,480 &, 770 & 2,842 \\
\hline P53(2) & 1,800 & ,499 & 13,000 & 1 &, 000 & 6,053 & 2,274 & 16,107 \\
\hline Paquetes / día (1) &,- 369 &, 382 & ,932 & 1 &, 334 & ,692 &, 327 & 1,462 \\
\hline P53 by Paq & & & 2,067 & 2 &, 356 & & & \\
\hline P53(1) by Paq(1) &,- 206 &, 474 & , 189 & 1 & 664 & 814 &, 322 & 2,060 \\
\hline P53(2) by Paq(1) &,- 931 & ,658 & 2,001 & 1 & , 157 & ,394 & ,109 & 1,432 \\
\hline Constante &,- 884 & ,273 & 10,512 & 1 &, 001 & ,413 & & \\
\hline
\end{tabular}

Resulta significativo el SNP P53 (chi-cuadrado 13,237; p-valor =0,001). La OR que resulta significativa es la correspondiente al genotipo Pro/Pro, que resulta ser un factor de riesgo. 
Número de años fumando

Tabla 162. Ajuste del modelo de regresión logistica en función del codon 72 de p53 y el número de años fumando.

\begin{tabular}{|c|c|c|c|c|c|c|c|c|}
\hline & \multirow[t]{2}{*}{$\beta$} & \multirow[t]{2}{*}{ E.T. } & \multirow[t]{2}{*}{ Wald } & \multirow[t]{2}{*}{$g l$} & \multirow[t]{2}{*}{ Sig. } & \multirow[t]{2}{*}{ O.R. } & \multicolumn{2}{|c|}{$\begin{array}{l}\text { I.C. } 95,0 \% \\
\text { para } O . R .\end{array}$} \\
\hline & & & & & & & Inf. & Sup. \\
\hline$P 53$ & & & 7,636 & 2 &, 022 & & & \\
\hline P53(1) &, 224 &, 341 & ,430 & 1 &, 512 & 1,251 & ,641 & 2,442 \\
\hline P53(2) & 1,229 &, 462 & 7,088 & 1 &, 008 & 3,417 & 1,383 & 8,442 \\
\hline NAños (1) &,- 560 &, 384 & 2,129 & 1 &, 145 &, 571 & ,269 & 1,212 \\
\hline P53 by NAños & & &, 148 & 2 & ,929 & & & \\
\hline P53(1) by NAños(1) & 152 &, 474 & ,103 & 1 &, 749 & 1,164 & ,460 & 2,944 \\
\hline P53(2) by NAños(1) &,- 017 & ,633 & ,001 & 1 & ,978 & ,983 &, 284 & 3,402 \\
\hline Constante &,- 769 & 278 & 7,680 & 1 &, 006 & ,463 & & \\
\hline
\end{tabular}

Resulta significativo el SNP P53 (chi-cuadrado 7,636; p-valor =0,022). La OR que resulta significativa es la correspondiente al genotipo Pro/Pro, que resulta ser un factor de riesgo. 


\section{General}

El modelo de regresión logística ajustado al aplicar el procedimiento stepwise tras 5 pasos se muestra en la siguiente tabla.

Tabla 163. Ajuste del modelo de regresión logística a partir de la introducción/eliminación progresiva de las variables genotipos en el codon 72 de p53, Edad, Núm. de paquetes/día y Núm. de años fumando.

\begin{tabular}{|c|c|c|c|c|c|c|c|c|}
\hline & \multirow[t]{2}{*}{$\beta$} & \multirow[t]{2}{*}{ E.T. } & \multirow[t]{2}{*}{ Wald } & \multirow[t]{2}{*}{$g l$} & \multirow[t]{2}{*}{ Sig. } & \multirow[t]{2}{*}{$O . R$. } & \multicolumn{2}{|c|}{$\begin{array}{c}\text { I.C. } 95,0 \% \\
\text { para } O . R .\end{array}$} \\
\hline & & & & & & & Inf. & Sup \\
\hline Edad & & & 49,897 & 4 &, 000 & & & \\
\hline $\operatorname{Edad}(1)$ & $-2,217$ &, 759 & 8,539 & 1 &, 003 & , 109 &, 025 & ,482 \\
\hline $\operatorname{Edad}(2)$ &,- 129 &, 375 & ,119 & 1 &, 730 & ,879 & ,421 & 1,833 \\
\hline $\operatorname{Edad}(3)$ & 1,523 &, 323 & 22,287 & 1 &, 000 & 4,587 & 2,437 & 8,632 \\
\hline $\operatorname{Edad}(4)$ & 1,057 & ,300 & 12,388 & 1 &, 000 & 2,878 & 1,597 & 5,184 \\
\hline Paq./día (1) &,- 599 & ,228 & 6,907 & 1 & ,009 &, 550 & ,352 & 859 \\
\hline P53 & & & 12,395 & 2 &, 002 & & & \\
\hline P53(1) & ,181 & ,259 & ,490 & 1 & ,484 & 1,199 & ,722 & 1,990 \\
\hline P53(2) & 1,196 &, 353 & 11,457 & 1 &, 001 & 3,307 & 1,654 & 6,610 \\
\hline
\end{tabular}

Las variables que resultan significativas son:

- Edad: Ser menor de 40 años es un factor de protección y tener entre 50 y 75 años es un factor de riesgo

- Número de paquetes al día fumados: fumar más de un paquete al día es un factor de riesgo

- SNP P53: ser portador del genotipo Pro/Pro es un factor de riesgo 


\section{IV.- P53 Intron 3}

\section{Edad}

Tabla 164. Ajuste del modelo de regresión logística en función del intrón 3 de p53 y la Edad

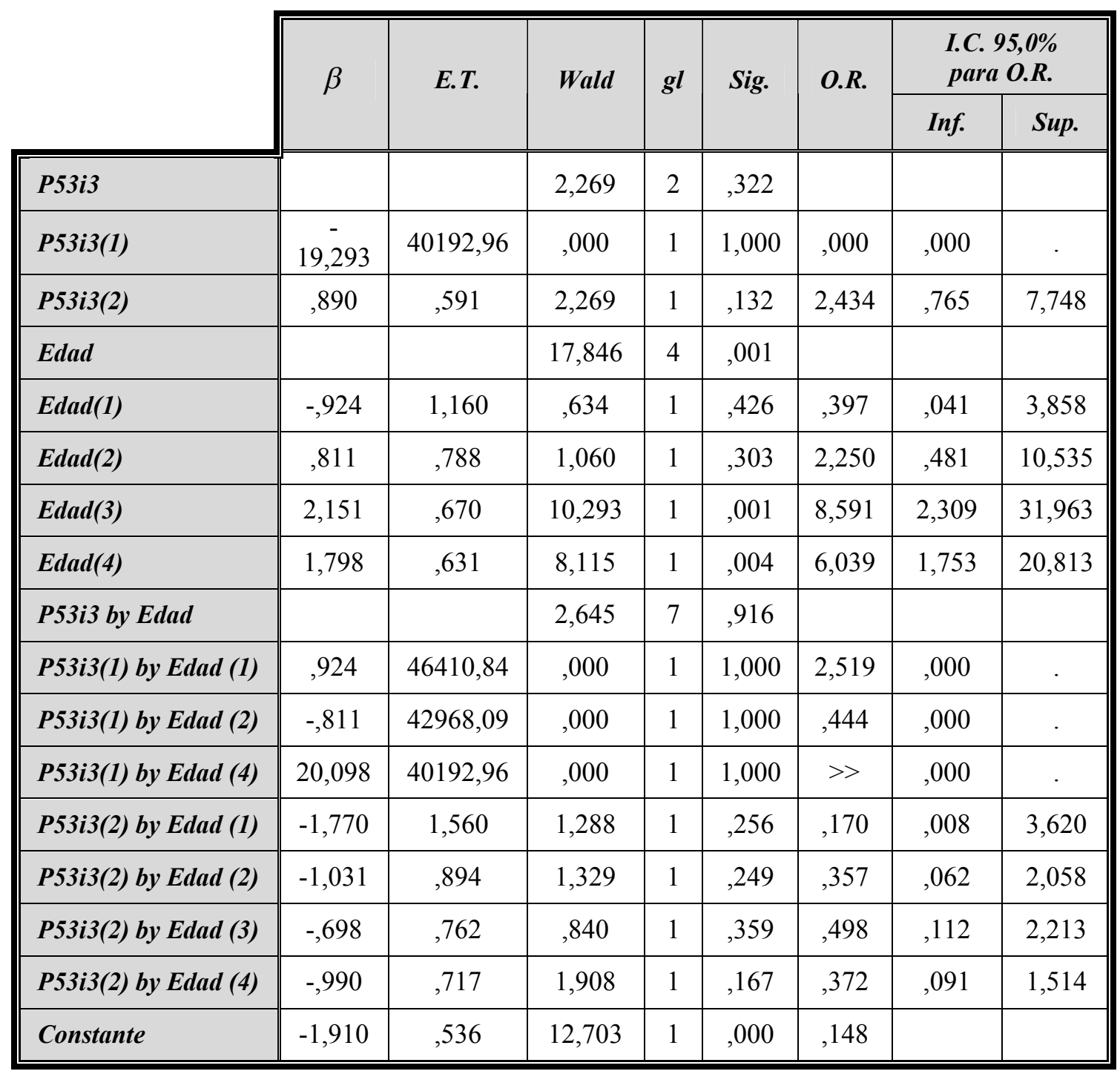

El único caso en el que el TRV es significativo es en la variable edad (chicuadrado 17,846; p-valor $=0,001$ ), es decir que rechazamos que individuos pertenecientes a distintos grupos de edad tengan el mismo riesgo de padecer cáncer de pulmón. Son significativos los coeficientes correspondientes a los grupos de edad $[50,65)$ y $[65,75)$. En ambos casos la OR es $>1$, es decir que individuos pertenecientes a estos grupos de edad tienen más riesgo de padecer cáncer de pulmón. 


\section{Número de paquetes/día}

Tabla 165. Ajuste del modelo de regresión logística en función del Intrón 3 de p53 y el número de paquetes/día.

\begin{tabular}{|c|c|c|c|c|c|c|c|c|}
\hline & \multirow[t]{2}{*}{$\beta$} & \multirow[t]{2}{*}{ E.T. } & \multirow[t]{2}{*}{ Wald } & \multirow[t]{2}{*}{$g l$} & \multirow[t]{2}{*}{ Sig. } & \multirow[t]{2}{*}{$O . R$. } & \multicolumn{2}{|c|}{$\begin{array}{l}\text { I.C. } 95,0 \% \\
\text { para } O . R .\end{array}$} \\
\hline & & & & & & & Inf. & Sup. \\
\hline P53i3 & & & 391 & 2 & 823 & & & \\
\hline P53i3(1) & $-5,735$ & 11,123 & ,266 & 1 & ,606 &, 003 &, 000 & $>>$ \\
\hline P53i3(2) & , 109 & ,319 & ,117 & 1 & ,732 & 1,115 &, 597 & 2,085 \\
\hline Paquetes / día (1) &,- 577 & ,386 & 2,233 & 1 &, 135 &, 561 & ,263 & 1,197 \\
\hline P53i3 by Paq & & & ,244 & 2 & 885 & & & \\
\hline P53i3(1) by Paq(1) & 5,391 & 11,155 & ,234 & 1 & ,629 & 219,32 &, 000 & $>>$ \\
\hline P53i3(2) by Paq(1) &,- 040 & ,456 & ,008 & 1 & ,930 & 961 & ,393 & 2,347 \\
\hline Constante &,- 464 & ,272 & 2,912 & 1 & ,088 & 629 & & \\
\hline
\end{tabular}

No hay ninguna variable que resulte estadísticamente significativa.

Número de años fumando

Tabla 166. Ajuste del modelo de regresión logística en función del Intrón 3 de p53 y el número de años fumando.

\begin{tabular}{|c|c|c|c|c|c|c|c|c|}
\hline & \multirow[t]{2}{*}{ 促 } & \multirow[t]{2}{*}{ E.T. } & \multirow[t]{2}{*}{ Wald } & \multirow[t]{2}{*}{$g l$} & \multirow[t]{2}{*}{ Sig. } & \multirow[t]{2}{*}{ O.R. } & \multicolumn{2}{|c|}{$\begin{array}{l}\text { I.C. } 95,0 \% \\
\text { para O.R. }\end{array}$} \\
\hline & & & & & & & Inf. & Sup. \\
\hline P53i3 & & & 5,352 & 2 &, 069 & & & \\
\hline P53i3(1) & 1,699 & 1,261 & 1,814 & 1 &, 178 & 5,467 & ,461 & 64,774 \\
\hline P53i3(2) &, 734 & ,346 & 4,496 & 1 &, 034 & 2,084 & 1,057 & 4,109 \\
\hline NAños (1) & ,418 &, 392 & 1,138 & 1 & ,286 & 1,519 &, 705 & 3,271 \\
\hline P53i3 by NAños & & & 6,741 & 2 &, 034 & & & \\
\hline P53i3(1) by NAños(1) & $-8,313$ & 11,127 &, 558 & 1 & ,455 &, 000 &, 000 & $>>$ \\
\hline P53i3(2) by NAños(1) & $-1,154$ & ,460 & 6,289 & 1 &, 012 &, 315 &, 128 & ,777 \\
\hline Constante & $-1,006$ & ,302 & 11,104 & 1 &, 001 & ,366 & & \\
\hline
\end{tabular}


Resulta significativa la interacción del SNP P53 intron 3 con el número de años fumando (chi-cuadrado 6,741; p-valor $=0,034$ ). La OR que resulta significativa es la correspondiente a haber fumado más de 38 años y portar el genotipo $90 \mathrm{bp}$, que resulta ser un factor de protección.

\section{General}

El modelo de regresión logística ajustado al aplicar el procedimiento stepwise tras 5 pasos se muestra en la siguiente tabla.

Tabla 167. Ajuste del modelo de regresión logística a partir de la introducción/eliminación progresiva de las variables genotipos en el intrón 3 de p53, Edad, Número de paquetes/día y Número de años fumando.

\begin{tabular}{|c|c|c|c|c|c|c|c|c|}
\hline & \multirow[t]{2}{*}{$\beta$} & \multirow[t]{2}{*}{ E.T. } & \multirow[t]{2}{*}{ Wald } & \multirow[t]{2}{*}{$g l$} & \multirow[t]{2}{*}{ Sig. } & \multirow[t]{2}{*}{$O . R$. } & \multicolumn{2}{|c|}{$\begin{array}{l}\text { I.C. } 95,0 \% \\
\text { para } O . R .\end{array}$} \\
\hline & & & & & & & Inf. & Sup. \\
\hline Edad & & & 49,619 & 4 &, 000 & & & \\
\hline $\operatorname{Edad}(1)$ & $-1,958$ &, 765 & 6,550 & 1 &, 010 &, 141 &, 031 & ,632 \\
\hline $\operatorname{Edad}(2)$ & , 104 & ,403 & ,067 & 1 & ,796 & 1,110 &, 504 & 2,445 \\
\hline $\operatorname{Edad}(3)$ & 1,673 & ,328 & 26,005 & 1 &, 000 & 5,328 & 2,801 & 10,134 \\
\hline $\operatorname{Edad}(4)$ & 1,043 & ,295 & 12,519 & 1 &, 000 & 2,839 & 1,593 & 5,059 \\
\hline Paq./día (1) &,- 518 & ,225 & 5,317 & 1 &, 021 & ,596 &, 384 & ,925 \\
\hline Constante &,- 879 & ,258 & 11,637 & 1 &, 001 & ,415 & & \\
\hline
\end{tabular}

Las variables que resultan significativas son:

- Edad: Ser menor de 40 años es un factor de protección y tener entre 50 y 75 años es un factor de riesgo

- Número de paquetes al día fumados: fumar más de un paquete al día es un factor de riesgo 


\section{5.- DISCUSIÓN}




\section{1.- Estudio de las variables no genéticas. Influencia de los factores de riesgo en el desarrollo de cáncer de pulmón.}

El $90 \%$ de los pacientes con cáncer de pulmón incluidos en este estudio presentaban tumores de estirpe histológica compatible con carcinoma no microcítico y un $10 \%$ compatible con carcinoma microcítico (Tabla 16), datos concordantes con los estudios epidemiológicos de distribución de subtipos histológicos ${ }^{246}$. Dentro de los subtipos histológicos de la variante no microcítica llama la atención la alta incidencia de tumores epidermoides. Esto se puede explicar por el hecho de que la mayoría de los pacientes eran varones y fumadores y el subtipo epidermoide es el más común en el varón y el más relacionado con el tabaco. Respecto a los otros dos subtipos, el Adenocarcinoma y el Carcinoma de Células Grandes, la proporción está acorde con lo referido en la literatura. Por último, en relación con la histología, observamos que los pacientes con cáncer no microcítico de pulmón comienzan a fumar más jóvenes que aquellos con cáncer microcítico (Tabla 25). Dada la desproporción de la muestra - 116 casos de cáncer no microcítico frente a 14 de cáncer microcítico- no podemos extrapolar ninguna conclusión de este resultado.

La media de edad al diagnóstico del tumor -63 años- se corresponde con el promedio descrito en población española, ya que es una patología que afecta sobre todo a personas mayores de 50 años, siendo el promedio de edad al diagnóstico de 60 años (Tabla 17).En relación con el riesgo ocupacional, observamos que la enfermedad pulmonar obstructiva crónica (EPOC) es el doble de frecuente en los pacientes con profesiones de riesgo (Tabla 19). El hecho de que la existencia de enfermedades pulmonares subyacentes se relacione con un mayor riesgo de desarrollar cáncer de pulmón puede explicar el mayor riesgo de cáncer de pulmón en los pacientes que realizan profesiones de riesgo ${ }^{25-29}$. Nuestros resultados muestran, como era de esperar, que los pacientes con antecedentes de EPOC fuman más paquetes al día (Tabla 21), pues el tabaco se ha demostrado como el principal factor de riesgo para desarrollar esta 
enfermedad ${ }^{30,31}$. El que en nuestro estudio los pacientes con antecedentes familiares oncológicos dejen de fumar a edades más tempranas (Tabla 23), puede reafirmar el hecho de que el riesgo a desarrollar cáncer de pulmón tras exposición a una sustancia carcinogénica está influenciado por la susceptibilidad genética de las personas, ya que los individuos no fumadores con familiares con cáncer de pulmón tienen un riesgo dos o tres veces mayor de desarrollar cáncer de pulmón que aquellos sin historia familiar ${ }^{21-24}$.

El análisis del grupo de fumadores sin cáncer de pulmón mostró una mayor incidencia de antecedentes de EPOC entre los individuos con profesiones de riesgo (Tabla 29), lo que concuerda con el hecho de que la bronquitis crónica es más frecuente en los trabajadores expuestos a polvos orgánicos o inorgánicos y a gases nocivos, que se incrementa en los trabajadores que también son fumadores ${ }^{247}$. Igualmente, en nuestra muestra es más frecuente que sujetos que viven en el medio urbano tengan antecedentes de EPOC (Tabla 28). Es sabido que existen más bronquíticos crónicos y enfisematosos en áreas urbanas muy industrializadas. No obstante, la mayoría de los pacientes de nuestro estudio eran residentes en la ciudad de Salamanca cuya industria y grado de polución atmosférica no se corresponde con el de áreas urbanas muy industrializadas como pueden ser Madrid, Barcelona, etc... La contaminación atmosférica y el consumo del tabaco tienen un efecto sinérgico nocivo sobre las vías aéreas y todo parece indicar que la primera incrementa el riesgo de los fumadores a desarrollar una EPOC. Aunque su importancia es muy inferior al tabaco, vivir en zonas donde existe un incremento en la atmósfera de partículas o gases anómalos, especialmente por dióxidos de azufre o nitrógeno, hidrocarburos y monóxidos de carbono generados por la combustión de los automóviles, calefacciones o la industria, produce un efecto irritativo bronquial que aumenta la aparición de síntomas respiratorios y de bronquitis crónica ${ }^{248-250}$.

La comparación entre los pacientes con cáncer de pulmón y los controles puso en evidencia que hay más mujeres entre los controles que entre los casos (9,40 vs $24,67 \%)$ principalmente a expensas de los controles fumadores menores de 65 años. Esto traduce la tendencia al alza de las mujeres jóvenes en el hábito tabáquico y muestra la 
necesidad de una estrategia eficaz en la lucha antitabáquica dirigida de forma específica a la población femenina. La observación de que cuanto mayor es el número de años que se lleva fumando y cuanto más es el número de paquetes de tabaco que se fuman al día, mayor es el riesgo de padecer cáncer de pulmón (Tabla 41), coincide con los resultados de numerosos estudios epidemiológicos que han establecido la relación entre el consumo de tabaco y el cáncer de pulmón ${ }^{82,87-89}$. No obstante, cuando comparamos el subgrupo de controles mayores de 65 años con los pacientes con cáncer de pulmón, se observa que al aumentar la edad de la población, disminuye el riesgo de paceder cáncer de pulmón y a medida que aumenta el número de años que se lleva fumando, también disminuye el riesgo de padecer cáncer de pulmón (Tabla 55). Este dato puede traducir una "selección natural” de la muestra: los pacientes más mayores son los que más años han fumado sin desarrollar cáncer por, entre otros factores, su mayor capacidad de reparación al daño del DNA producido por el tabaco. Por el contrario, aquellos pacientes más susceptibles y con menor capacidad de reparación del DNA desarrollarán cáncer, pasando a formar parte del grupo de los casos.

\section{2.- Estudio del Polimorfismo en el codon 72 del Exón 4 de p53.}

Dado que únicamente un pequeño porcentaje de las personas fumadoras desarrollan cáncer de pulmón, otros factores, entre los que se incluye la susceptibilidad genética, deben ser importantes en la determinación del riesgo del cáncer de pulmón ${ }^{50}$. El gen supresor de tumores p53 aparece mutado en muchos tipos de carcinomas humanos, teniendo una implicación fundamental en el desarrollo tumoral, pues se encuentra mutado en aproximadamente el 50\% de los tumores malignos ${ }^{174}$, de forma que, en situaciones de daño al DNA no se detiene el ciclo celular favoreciendo la proliferación de células mutadas ${ }^{154,176}$.

De los 393 codones distribuidos en 11 exones que constituyen el gen TP53, se ha descrito un polimorfismo en el codón 72 del exón 4, que codifica dos tipos de alelos, arginina (CGC) o prolina (CCC). Este polimorfismo, al igual que en otros exones de 
p53, se ha asociado con una mayor susceptibilidad para desarrollar cáncer, y entre ellos el cáncer de pulmón ${ }^{194,219-224}$. Sin embargo, no todos los estudios han sido consistentes, y esta asociación continua siendo controvertida ${ }^{194,217}$.

El tipo de daño genético en el cáncer de pulmón difiere del que ocurre en otros tumores sólidos, y ha sido asociado a la carcinogénesis del humo del tabaco. Los hidrocarburos policíclicos aromáticos presentes en el humo de los cigarros se unen a determinados lugares que han sido correlacionados con diversos "puntos calientes" mutacionales descritos en el gen TP53 ${ }^{181,251,252}$. Esto sumado a la menor capacidad que presentan algunos pacientes con cáncer de pulmón de reparar el daño inducido al DNA por los carcinogenos del tabaco ${ }^{236}$, constituye un punto crucial en el proceso de mutagénesis ${ }^{253-255}$. La prevalencia global de mutaciones en TP53 está igualmente incrementada en aquellos casos de cáncer de pulmón de pacientes fumadores respecto a no fumadores ${ }^{256}$.

El gen TP53 juega un importante papel en la apoptosis, el control del ciclo celular y la reparación del DNA, y estas funciones difieren entre las diferentes proteínas codificadas por los alelos arginina o prolina. Muchas de las diferencias funcionales entre estos dos alelos podrían resultar en un incremento del daño mutacional en el gen TP53 derivado de la exposición carcinógena del tabaco. Wu [et al.] demostraron una disminución de la apoptosis tras daño radiactivo al DNA y una menor capacidad para reparar el DNA tras exposición a benzopirenos (carcinógeno del tabaco) en líneas celulares linfoblásticas que contenían el alelo prolina ${ }^{231}$. De esta manera, la perdida funcional del gen TP53 produce una disminución en la reparación global del DNA tras la exposición a carcinógenos del tabaco como los benzopirenos ${ }^{257}$.

El alelo prolina es menos efectivo en la inducción de apoptosis que el alelo arginina. La proteína codificada por el alelo arginina se une a MDM-2 con mayor afinidad, y esto produce un aumento del trasporte de la proteína p53 a la mitocondria ${ }^{258}$. Por otra parte, el alelo prolina puede ser menos activo a la hora de producir la 
parada del ciclo celular propia del gen TP53 como respuesta al daño producido en el DNA. La forma arginina de TP53 es más potente en la inducción de la expresión de p21 WAF1, inhibición del ciclo celular, y supresión del crecimiento de células mutadas ${ }^{227}$.

Varios estudios han sugerido que el alelo arginina del codon 72 se encuentra mutado con más frecuencia en las formas heterozigóticas Arg/Pro que en las homocigóticas Arg/Arg, adquiriendo una mayor ventaja de crecimiento en función de la proporción de alelos arginina y prolina mutados en el tumor ${ }^{259,} 260$.

Diversos estudios han investigado la implicación de este polimorfismo y el riesgo para desarrollar diferentes tipos de cáncer. Así, hay estudios en los que se ha observado una asociación estadísticamente significativa entre la variante arginina de este polimorfismo y el riesgo de desarrollar cáncer de mama ${ }^{259,261,48}$, y otros en los que este riesgo se ha visto asociado a la variante prolina ${ }^{262}$. Estos resultados pueden estar condicionados por el hecho de que se han estudiado poblaciones de mujeres de diferente raza, lo cual apoya la hipótesis de que en el carcinoma de pulmón la relación del riesgo se modifica según el origen étnico del paciente ${ }^{50,263,264}$.

Respecto a otros tumores, como el cáncer de próstata, hay estudios en los que se sugiere que la variante prolina confiere un mayor riesgo de desarrollar dicho tumor ${ }^{265}$, y otros en los que no se ha encontrado una asociación estadísticamente significativa ${ }^{266}$. Lo mismo ocurre con otros tumores genitourinarios, como el cáncer de vejiga ${ }^{267-269}$, el carcinoma de cervix ${ }^{270-272}$, el carcinoma de endometrio ${ }^{273}$, y el de ovario ${ }^{274,275}$.

En otros muchos tipos histológicos de tumores se ha estudiado la posible implicación de este polimorfismo, como el carcinoma gástrico ${ }^{276,277}$, tumores del Sistema Nervioso Central como el meningioma ${ }^{278}$, tumores de la piel ${ }^{279}$, etc... encontrándose resultados diversos.

Respecto al Cáncer de Pulmón, al igual que en el resto de tumores, la mayoría de los estudios epidemiológicos han sido de casos-controles, observándose una asociación 
positiva, incrementando el riesgo, tanto para el genotipo homocigoto prolina ${ }^{194,}$ 217, 219, 220, 222-224, como para el genotipo heterocigoto arginina/prolina ${ }^{194,222}$. Igualmente se han publicado estudios en los que no se ha demostrado un incremento del riesgo de desarrollar cáncer de pulmón con dichas variantes genotípicas ${ }^{219,226-229, ~} 245$.

El polimorfismo en el codon 72 de gen p53 ha sido igualmente evaluado como factor pronóstico y marcador predictivo en el cáncer de pulmón, encontrándose en algunos estudios una menor supervivencia en pacientes con la variante Prolina ${ }^{218,280}$.

El hecho de que este polimorfismo juegue un papel más importante en el carcinoma de pulmón que en otros tumores, como el de vejiga, mama, colorectal, etc... puede deberse a que el papel del gen TP53 es importante en la reparación del daño al DNA expuesto a la carcinogénesis inducida por el tabaco.

Existen datos que apuntan a que los diferentes genotipos del polimorfismo de TP53 incrementan el riesgo de desarrollar determinados subtipos histológicos del carcinoma no microcítico de pulmón, especialmente la variedad de adenocarcinoma ${ }^{194,}$ 218, 221, 224 . También se ha descrito un aumento de riesgo de cáncer entre los pacientes con el alelo Prolina en función del número de paquetes-año fumados ${ }^{194}$, si bien otros estudios no encontraron diferencias entre grandes y pequeños fumadores ${ }^{218}$.

En nuestro trabajo hemos encontrado en los test de asociación una serie de resultados significativos, si bien hemos de ser cautos a la hora de interpretar los datos ya que en este polimorfismo no se cumple el Equilibrio de Hardy-Weinberg en el grupo de controles de 65 años o más (Tabla 65) y en el grupo de pacientes con cáncer (Tabla 79) donde resultan significativas las comparaciones entre Pro/Pro y el resto. En el primer grupo -controles de 65 años o más-, portar el genotipo Pro/Pro aumenta el riesgo de padecer cáncer de pulmón, siendo 2,725 veces más probable encontrar el genotipo Pro/Pro en lugar de Arg/Arg y 2,901 veces en lugar de Arg/Pro entre los casos con cáncer (Tabla 86). En el grupo de control global los resultados son similares, siendo 2,532 veces más probable encontrar el genotipo Pro/Pro en lugar de Arg/Arg y 3,437 
veces más probable encontrar el genotipo Pro/Pro en lugar de Arg/Pro entre los casos con cáncer (Tabla 97). Así pues, considerando como control los exfumadores con 65 años o más, los exfumadores con menos de 65 años y los dos grupos de edad a la vez, portar el genotipo Pro/Pro en el SNP P53, aumenta el riesgo de padecer cáncer de pulmón. Ser portador del alelo Arg en este caso, es un factor de protección (Tabla 98).

El hecho de que este polimorfismo no cumpla el Equilibrio de Hardy-Weinberg en el grupo de controles de 65 años o más, donde resultan significativas las comparaciones entre Pro/Pro y el resto de genotipos, refuerza aun más la posibilidad de que el alelo Arginina proteja frente al cáncer de pulmón, dado que hemos sesgado la población a estudio al incluir solo fumadores y no población general. Hemos realizado una "selección natural”: los controles que tienen menos alelos arginina y más alelos prolina serían más susceptibles a desarrollar cáncer de pulmón y mueren. Esto explica que haya más alelos arginina en los controles mayores de 65 años, al ser los fumadores con mayor protección frente al cáncer de pulmón y, consecuentemente, no se cumpla el Equilibrio de Hardy-Weinberg. En las siguiente dos tablas podemos ver cómo el porcentaje de los genotipos Arg/Arg aumenta en los controles mayores de 65 años respecto a los menores de 65 años (59,6\% vs 49,67\%), y permanece igual en el grupo de los casos (51,67\% vs 51,67\%).

Tabla 168. Tabla de contingencia de los genotipos del codon 72 de p53 según grupo experimental caso o control de menos y más de 65 años.

\begin{tabular}{|c|c|c|c|c|c||}
\cline { 3 - 5 } \multicolumn{1}{c|}{} & \multicolumn{3}{c|}{ P53 } & \multirow{2}{*}{ Total } \\
\cline { 3 - 5 } \multicolumn{1}{c|}{} & Arg/Arg & Pro/Pro & Arg/Pro & \\
\hline \multirow{2}{*}{ Casos } & $<\mathbf{6 5}$ años & $51,67 \%$ & $23,48 \%$ & $24,83 \%$ & $100 \%$ \\
& $>\mathbf{6 5}$ años & $51,67 \%$ & $23,48 \%$ & $24,83 \%$ & $100 \%$ \\
\hline \multirow{2}{*}{ Controles } & $<\mathbf{6 5}$ años & $49,6 \%$ & $9,6 \%$ & $40,6 \%$ & $100 \%$ \\
& $>\mathbf{6 5}$ años & $59,6 \%$ & $9,93 \%$ & $30,46 \%$ & $100 \%$ \\
\hline
\end{tabular}

$(\mathrm{p}<0,05)$ 
En los estudios de regresión logística observamos que en los controles mayores de 65 años, el ser portador del genotipo Pro/Pro es un factor de riesgo. La odds-ratio respecto de ser heterocigoto es 2,901, es decir, pacientes con Pro/Pro tienen más riesgo de padecer cáncer de pulmón que los pacientes portadores de Arg/Pro (Tabla 103). Este incremento de riesgo es estadísticamente significativo (IC 95\% 1,379 ; 6,103).

Cuando estudiamos la relación entre las variables no genéticas, en el caso de la edad en la muestra de individuos con edades entre los 65 y los 75 años, es significativamente más frecuente encontrar homocigotos que en la muestra de individuos menores de 65 años (Tabla 132). En el número de paquetes / día no hay evidencias de que exista una asociación entre el número de paquetes fumados al día y ser portador de un genotipo específico en este SNP (Tabla 134). Respecto al número de años fumando no hay evidencias de que exista una asociación entre el número de años fumando y ser portador de un genotipo específico en este SNP (Tabla 135).

Cuando planteamos modelos de regresión logística que intenten explicar el riesgo que tiene un individuo de desarrollar cáncer de pulmón en función de cada SNP junto con cada una de estas variables no genéticas, el único caso en el que el TRV es significativo es en la variable edad (chi-cuadrado 20,235; p-valor < 0,001). Rechazamos que individuos pertenecientes a distintos grupos de edad tengan el mismo riesgo de padecer cáncer de pulmón. Son significativos los coeficientes correspondientes a los grupos de edad [50-65] y [65-75]. En ambos casos la OR es $>1$, es decir que individuos pertenecientes a estos grupos de edad tienen más riesgo de padecer cáncer de pulmón (Tabla 160). Cuando estudiamos el número de paquetes / día la asociación resulta significativa (chi-cuadrado 13,237; p-valor =0,001). La OR que resulta significativa es la correspondiente al genotipo Pro/Pro, que resulta ser un factor de riesgo (Tabla 160). Cuando estudiamos el número de años fumando la asociación resulta significativa (chi-cuadrado 7,636; p-valor $=0,022$ ). La OR que resulta significativa es la correspondiente al genotipo Pro/Pro, que resulta ser un factor de riesgo (Tabla 162). 
Así pues, podemos concluir que en nuestro trabajo observamos que el alelo Prolina se asocia de forma significativa con un mayor riesgo de desarrollar cáncer de pulmón, y que el alelo Arginina se asocia de forma significativa con un efecto protector, al encontrarse con mayor frecuencia en el grupo control fumador. Por otra parte, nuestro estudio es el primero que se realiza incluyendo un grupo control de personas fumadoras que no desarrollen cáncer de pulmón, lo cual nos permite discriminar un factor causal tan crucial en el cáncer de pulmón como es el tabaco, pudiendo realizar una asociación más precisa. En el estudio de asociación genética ser portador del genotipo Pro/Pro y/o fumar más de un paquete al día y/o tener entre 50 y 75 años resultaron factores de riesgo. Ser menor de 40 años resulto ser un factor de protección. Se encontró asociación entre el SNP P53 y el grupo de edad, siendo más frecuente encontrar homocigotos (Arg/Arg o Pro/Pro) en individuos cuya edad está entre los 65 y los 75 años, que en individuos con menos de 65. Estos datos concuerdan con la mayoría de los publicados en la literatura y comentados con anterioridad.

En este sentido, mostramos por primera vez que los individuos fumadores que no desarrollan cáncer de pulmón son portadores del alelo Arg con más frecuencia que la población general, lo que sugiere que el ser portador de este alelo podría proteger frente al desarrollo de cáncer de pulmón en fumadores. Es necesario hacer el estudio en una serie más grande para confirmar los resultados.

\section{3.- Estudio del Polimorfismo en el intrón 3 de p53.}

La repetición única de 16 nucleótidos en el intrón 3 de p53 se describió por primera vez en 1993 en la población caucásica, observándose un 28\% de heterocigosidad en los 82 pacientes estudiados ${ }^{230}$. Dos estudios han examinado la asociación entre el polimorfismo en el intrón 3 y el riesgo de cáncer de pulmón. En uno de ellos no se detectó asociación significativa entre este polimorfismo y el riesgo de cáncer de pulmón, con una OR 1.24 (95\% CI 0.37士4.20) para la variante alela homocigota y 0.74 (95\% CI $0.46 \pm 1.18$ ) para los potadores ${ }^{229}$. En otro estudio se 
observó un incremento del riesgo de cáncer de pulmón para los homocigotos (OR ajustada 2.37, 95\% CI 0.76 \pm 7.39 ) y para los portadores de los genotipos con el alelo variante $(1.77,95 \%$ CI 1.24 \pm 2.52$)$ en la raza caucásica e hispano-americanos. Esta asociación no se observo en la raza afroamericana ${ }^{231}$. La OR común para la variante alela homocigota y los genotipos portadores fue 1.50 (95\% CI 0.76 2.97$)$ y 1.11 (95\% CI $0.53 \pm 2.35$ ) respectivamente.

Este polimorfismo ha sido estudiado en otros tipos de tumores. En el cáncer de ovario un estudio encontró un mayor riesgo de desarrollar el cáncer en los pacientes con la variante genotípica ${ }^{281}$. Sin embargo otros dos estudios no encontraron dicha asociación ${ }^{282,283}$.

En nuestro trabajo hemos encontrado en los test de asociación una serie de resultados significativos, si bien hemos de ser cautos a la hora de interpretar los datos ya que en este polimorfismo no se cumple el Equilibrio de Hardy-Weinberg en el grupo de controles de menos de 65 años donde resultan significativas las comparaciones entre 106bp y el resto (Tabla 71), donde parece que portar el genotipo 106bp disminuye el riesgo de padecer cáncer de pulmón. En el grupo control de 65 años o más, es 5,650 veces más probable encontrar el genotipo 90bp en lugar de 106bp y 5,495 veces más probable encontrar el genotipo 106+90bp en lugar de 106bp entre los casos con cáncer (Tabla 94). En el grupo control de menos de 65 años es 5,618 veces más probable encontrar los genotipos 90bp y 106+90bp entre los casos de cáncer (Tabla 95). Estos resultados difieren con los de $\mathrm{Wu}$ [et al.] en donde se observo un incremento del riesgo de cáncer de pulmón para los pacientes homocigotos y para los portadores de los genotipos con el alelo variante en la raza caucásica e hispano-americanos ${ }^{231}$. Si embargo, cuando consideramos los dos grupos control (menores de 65 y mayores o igual a 65 años) como un único grupo de controles, no hay evidencias de que portar el alelo 90bp o equivalentemente el genotipo 106bp incremente el riesgo de padecer cáncer de pulmón. No hay evidencias de que portar un determinado alelo en este SNP incremente en riesgo de padecer cáncer de pulmón (Tabla 100). 
Cuando planteamos modelos de regresión logística que intenten explicar el riesgo que tiene un individuo de desarrollar cáncer de pulmón en función de cada SNP junto con cada una de estas variables no genéticas, ningún grupo control presenta asociación con el cáncer de pulmón, si bien en el grupo control de menos de 65 años (donde no se verifica el equilibrio de Hardy - Weinberg) los pacientes que portan 106bp tienen significativamente menos riesgo que pacientes con 106+90bp. Hay que ser muy cautelosos con este resultado puesto que sólo hay 13 individuos portadores de 106bp (Tabla 106).

Cuando estudiamos la relación entre las variables no genéticas, en el caso de la edad, en la muestra de individuos con edades entre los 40 y los 50 años, es significativamente más frecuente encontrar homocigotos del tipo 90bp en lugar de 106bp, que en la muestra de individuos menores de 40 años (Tabla 138). No hay individuos portadores de 106bp en la muestra de individuos con edades entre los $50 \mathrm{y}$ los 65 años (Tabla 139). En la muestra de individuos menores de 50 años, es significativamente más frecuente encontrar homocigotos, que en la muestra de individuos cuya edad este en el intervalo 50-65 años (Tabla 145). En las variables número de paquetes / día y número de años fumando no hay evidencias de que exista una asociación entre el número de paquetes fumados al día y el número de años fumados con ser portador de un genotipo específico en este SNP (Tablas 149 y 151).

Cuando planteamos modelos de regresión logística que intenten explicar el riesgo que tiene un individuo de desarrollar cáncer de pulmón en función de cada SNP junto con cada una de estas variables no genéticas, el único caso en el que el TRV es significativo es en la variable edad (Chi-cuadrado 17,846; p-valor =0,001). Es decir, que rechazamos que individuos pertenecientes a distintos grupos de edad tengan el mismo riesgo de padecer cáncer de pulmón. Son significativos los coeficientes correspondientes a los grupos de edad [50-65] y [65-75]. En ambos casos la OR es >1, es decir que individuos pertenecientes a estos grupos de edad tienen más riesgo de padecer cáncer de pulmón (Tabla 164). Igualmente resulta significativa la interacción 
del SNP P53 intron 3 con el número de años fumando (Chi-cuadrado 6,741; p-valor = 0,034). La OR que resulta significativa es la correspondiente a haber fumado más de 38 años y portar el genotipo 90bp, que resulta ser un factor de protección (Tabla 166).

Así pues, resultan significativas 2 variables: edad y número de paquetes que se fuma al día, de forma que fumar más de un paquete al día y/o tener entre 50 y 75 años son factores de riesgo. Además ser menor de 40 es un factor de protección. La interacción del SNP P53 intron 3 con el número de años fumando es significativa en el modelo sencillo, de forma que portar el genotipo 90bp y haber fumado más de 38 años es un factor de protección. Estos datos no los podemos comparar con los de otros estudios debido a la falta de estratificación por estas variables en los estudios publicados.

\section{4.- Estudio del Polimorfismo en el Gen XRCC1}

Se han identificado un gran número de polimorfismos (SNPs) en genes de

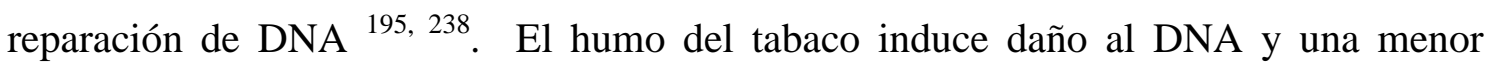
capacidad para reparar el DNA se ha asociado con un mayor riesgo de cáncer de pulmón ${ }^{233-237}$. Estos estudios sugieren que una menor capacidad de actuación en varios mecanismos de reparación del DNA predisponen individualmente al cáncer de pulmón. Los polimorfismos en los genes de reparación del DNA se pueden asociar con diferencias en la reparación del DNA dañado, pudiendo influir en el riesgo individual de cáncer de pulmón debido a que la variante genotípica en ese polimorfismo puede destruir o alterar la función reparadora.

XRCC1 juega un importante papel en el proceso de reparación de escisión de nucleótidos. El hecho de que polimorfismos en estos genes reparadores disminuyen la capacidad para la reparación del daño causado al DNA por el tabaco queda reflejado en trabajos que demuestran que polimorfismos en XRCC1 pueden modificar el riesgo de cáncer de pulmón en función del numero de paquetes/año fumados 201, 239-241. 
El gen XRCC1 expresa una proteína involucrada en la adecuada reparación de los puentes de unión en el DNA producidos por la exposición a radiaciones ionizantes y agentes alquilantes. Esta proteína interactúa con la DNA ligasa III, DNA polimerasa beta, APE, polinucleótido kinasa y poil(ADP-ribosa) polimerasa, participando en la vía de reparación por escisión de bases. Puede jugar un papel en el procesamiento del DNA en las células germinales. El gen de XRCC1 se localiza en el cromosoma19q13.2. Está formado por 17 exones y codifica una proteína de 633 aminoácidos. Los polimorfismos de nucleótido único (SNP) más ampliamente estudiados en trabajos epidemiológicos de cáncer son Arg280His localizado en el exón 9, Arg399Gln localizado en el exón 10 y Arg194Trp localizado en el exón 6 y que es el polimorfismo estudiado en nuestro trabajo doctoral.

Se han encontrado asociaciones entre polimorfismos en XRCC1 y mutaciones en el gen p53 que pudieran explicar el papel de XRCC1 en el daño al DNA inducido por el tabaco en pacientes con cáncer de pulmón ${ }^{243}$. En XRCC1 existen estudios a favor ${ }^{284-}$ ${ }^{286}$ y en contra ${ }^{287}$ de la asociación a una mayor susceptibilidad a desarrollar cáncer de pulmón. Igualmente se han encontrado asociaciones entre polimorfismos en XRCC1 y una mayor susceptibilidad a padecer determinados subtipos histológicos de cáncer de pulmón ${ }^{241,288}$.

Estudios epidemiológicos que relacionan riesgo de desarrollar cáncer de pulmón en función de los polimorfismos en los genes reparadores de tumores han demostrado una diferente susceptibilidad según el tipo de raza. Así, un reciente meta-análisis demuestra un incremento en el riesgo de desarrollar cáncer de pulmón en la población asiática que presentaba el genotipo 399Gln/Gln del polimorfismo de XRCC1 Arg399Gln, pero no entre la población caucásica ${ }^{289}$. También se han observado diferencias en función del sexo, encontrándose un efecto protector del polimorfismo 399Gln de XRCC1 frente al cáncer de pulmón en mujeres no fumadoras ${ }^{290}$. Polimorfismos en XRCC1 se han visto implicados en una mayor respuesta a los tratamientos quimioterápicos instaurados para el tratamiento del cáncer de pulmón 
debido a la mayor dificultad para la reparación del daño inducido al DNA ${ }^{291}$, pero también en un peor pronóstico y supervivencia ${ }^{292}$.

El polimorfismo Arg399Gln de XRCC1 es la secuencia más frecuente entre los tres polimorfismos. En un meta-análisis con 11 estudios no se encontró asociación entre este polimorfismo y un mayor riesgo de desarrollar cáncer de pulmón ${ }^{289}$,si bien el genotipo 399Gln/Gln se asoció con un incremento del cáncer de pulmón entre la población asiática (OR=1.34, 95\% CI:1.16-1.54). El alelo Gln de XRCC1 Arg399Gln se ha asociado con un incremento de los niveles de DNA dañado y eso puede ser debido a una disminución en la capacidad de reparación del DNA como se refleja en diferentes estudios que muestran un aumento de los niveles de aductos en el DNA, variantes de la glycoporina A y sensibilidad a la bleomicina así como cambios en la frecuencia de cromátidas. En el estudio con mayor número de población caucásica la OR del polimorfismo Arg399Gln de XRCC1 fue de 1.3. Un análisis estratificado reveló que la OR disminuía al aumentar el número de paquetes-año. Para no fumadores la OR fue de 2.4 mientras que para grandes fumadores (>55 paquetes-año) la OR descendió a $0.5^{293}$. Cinco estudios fueron publicados después del meta-análisis ${ }^{240}$. En ellos tampoco se encontró asociación entre este polimorfismo y el cáncer de pulmón, si bien el modelo recesivo de el análisis multivariante stepwise reveló un efecto protector del genotipo 399Gln/Gln ${ }^{294}$. El polimorfismo Arg399Gln de XRCC1 ha sido asociado con un mayor riesgo de cáncer de mama entre la población afro-americana pero no entre la caucásica ${ }^{295,296}$, indicando que este polimorfismo puede estar asociado a otra mutación biológicamente efectiva. Otras razones para esta aparente diferencia de riesgo entre diferentes poblaciones étnicas no son todavía conocidas, pudiendo ser debidas a otros factores genéticos ó ambientales.

Respecto al polimorfismo Arg280His de XRCC1, hay resultados diversos. En un estudio, los genotipos combinados Arg/His y His/His se asociaron con un incremento del riesgo de cáncer de pulmón ${ }^{53}$. Sin embargo otros estudios no han encontrado dicha asociación ${ }^{58,31}$. En un meta-análisis de estos tres estudios no se encontró asociación 
entre el polimorfismo y un mayor riesgo de cáncer de pulmón (genotipos combinados Arg/His y His/His frente al genotipo Arg/Arg) ${ }^{240}$. Cuatro estudios sobre este polimorfismo han sido publicados con posterioridad al meta-análisis. Uno de ellos fue en población danesa, no encontrándose asociación ${ }^{287}$. En otro realizado en población germana, los pacientes que portaban al menos un alelo 280His no mostraban un aumento del riesgo ${ }^{297}$. Igualmente, los genotipos combinados Arg/His y His/His no se asociaron con un incremento del riesgo en la población china y noruega ${ }^{298,299 .}$

En cuanto al polimorfismo a estudio en este trabajo doctoral (Arg194Trp), recientes estudios han encontrado una ligera asociación entre el genotipo 194 Trp/Trp y el riesgo de desarrollar cáncer de pulmón en determinadas razas como la hindú ${ }^{300}$. En este trabajo, al estudiar a la población no fumadora, sólo el genotipo 194 Arg/Trp se asoció positivamente con el cáncer de pulmón. Una revisión que incluía 16 estudios con 4895 casos y 5977 controles, encontró un efecto protector de este polimorfismo en los cánceres relacionados con el tabaco (OR=0.86, 95\% CI: 0.77, 0.95), incluyendo cáncer de pulmón, tracto aéreodigestivo superior, vejiga, estómago, hígado, páncreas y leucemia mieloide crónica ${ }^{240}$. Esto es compatible con la evidencia de la baja capacidad mutagénica de este alelo.

Un meta-análisis basado en ocho estudios con 9 poblaciones étnicas diferentes mostró que no existía asociación entre el polimorfismo Arg194Try y riesgo de cáncer de pulmón. El efecto del alelo Try fue escaso y sin variaciones entre las diferentes poblaciones ${ }^{289}$. Ratnasinghe [et al.] observaron una disminución no significativa del riesgo de cáncer de pulmón asociada con el genotipo 194Trp/Trp entre la población china ${ }^{301}$. David-Beabes y London observaron una disminución estadísticamente significativa del riesgo de cáncer de pulmón con el genotipo 194Arg/Try respecto al genotipo 194Arg/Arg en población afro-americana, si bien el escaso número de genotipos Try/Try no permitió hacer estimaciones precisas en esta categoría. A diferencia de la afro-americana, en este estudio no se observó ninguna asociación entre la población caucásica ${ }^{302}$. Por el contrario, Chen [et al.] encontraron un discreto 
aumento del riesgo con el genotipo 194Try/Try en la población asiática ${ }^{303}$. Otro estudio en población caucásica mostró que los pacientes con cáncer de pulmón que portaban al menos un alelo 194 Try no presentaban un aumento del riesgo ${ }^{297}$. Igualmente no se observó asociación entre el polimorfismo Arg194Try y riesgo de cáncer de pulmón en otros dos estudios con población caucásica ${ }^{294,299 .}$

Respecto a los otros tumores relacionados con el tabaco los resultados son parecidos. En el cáncer de la vía aéreodigestiva superior los estudios de casos y controles muestran diferentes asociaciones, incrementándose el riesgo en los pacientes fumadores y bebedores con genotipos Trp/Trp y Arg/Trp ${ }^{304,305}$, y no encontrándose esta asociación en otros estudios ${ }^{306-308}$. En el cáncer de vejiga se encontró un cierto efecto protector en los pacientes que presentaban al menos una copia de la variante alélica respecto a los que eran homocigóticos para el alelo común ${ }^{309}$. En el cáncer colorectal un estudio muestra un aumento del riesgo para los genotipos Arg/Trp, llamando la atención una mayor asociación en pacientes menores de 40 años y con residencia urbana 310. En el caso del cáncer gástrico y de próstata, no se han encontrado datos concluyentes.

Polimorfismos en Arg194Trp de XRCC1 se han estudiado en otros tipos de tumores no relacionados con el tabaco, encontrándose resultados diversos. Así en el cáncer de mama, un estudio en la población americana no encontró dicha asociación 311 . Otro estudio realizado en mujeres posmenopáusicas estadounidense observó una asociación inversa significativa entre las formas que incluían Trp (Trp/Trp y Trp/Arg) comparadas con las que no incluían Trp (Arg/Arg), siendo esta asociación discretamente mayor entre las mujeres fumadoras ${ }^{312}$. Otro estudio realizado por el MD Anderson Cancer Centre tampoco encontró asociación entre este polimorfismo y un mayor riesgo para desarrollar cáncer de mama ${ }^{313}$.

En nuestro trabajo doctoral al analizar los resultados ajustados a un modelo de regresión logística incluyendo el propio SNP, las 3 variables no genéticas y sus 
interacciones, se encuentra que en el modelo general la única variable que resulta significativa es la edad, de forma que individuos con edades comprendidas entre los 65 y 75 años tienen más riesgo de padecer cáncer de pulmón (Tabla 159). Cuando consideramos cada variable por separado, la edad no resulta significativo, pero sí el número de años fumando, de forma que fumar más de 38 años es un factor de riesgo (Tabla 158). Esto puede deberse a la relación que existe entre la edad y el número de años fumando. Los resultados de nuestro estudio concuerdan con la mayoría de los publicados en la literatura, si bien existen algunas diferencias con los datos de otros trabajos realizados en poblaciones de diferente etnia como la asiática. Esto ocurre de forma similar con otros estudios comentados previamente. Aunque las razones para la inconsistencia en las diferentes publicaciones no es clara, son dos las posibles explicaciones: 1) la baja frecuencia del genotipo de "riesgo" y 2) el pequeño tamaño muestral de los estudios realizados. Respecto a las diferencias étnicas, estas pueden estar causadas por las interacciones gen-gen, las diferentes conexiones entre los polimorfismos o los diferentes estilos de vida.

\section{5.- Estudio del Polimorfismo en el Gen ERCC1}

Desde hace ya más de una década es bien sabido que el mecanismo de reparación por escisión de nucleótidos está involucrado en la resistencia a la quimioterapia en ciertos tipos de tumores, incluyendo las sales de platino. En 2006, Olaussen [et al.] publicaron que la ausencia de evidencia inmunohistoquímica de la proteína ERCC1 en los tumores se asociaba a un beneficio en la supervivencia en los carcinomas no microcíticos de pulmón tratados con quimioterapia basada en cisplatino ${ }^{141 .}$ ERCC1 es una proteína altamente conservada esencial para la vida. Si bien es solo una de las múltiples proteínas implicadas en la reparación por escisión de nucleótidos, juega un papel limitante de función. Forma un complejo con otra proteína, XPF, y el heterodímero realiza el último de los pasos iniciales en la vía de reparación por escisión de nucleótidos - la escisión del extremo 5’ de la hebra de DNA en el lugar del DNA dañado. La expresión de ERCC1 está influenciada por complejos factores, incluyendo 
polimorfismos y uniones alternativas.

Los dos polimorfismos de ERCC1 más estudiados en cáncer de pulmón son el 3’ UTR (C8092A, dbSNP no. rs3212986) y el codon 118 (Asn118Asn, T19007C, dbSNP no. Rs11615).

Respecto al polimorfismo T19007 C (Asn118Asn), aunque el genotipo T/T produce la secuencia de triple codon menos frecuentemente asociada que codifica el aminoácido, ha sido denominada "la variante" por consenso. Este genotipo se ha observado que aparece en grandes frecuencias. El genotipo del polimorfismo C/C de T19007C se asocio con un descenso significativo del riesgo de cáncer de pulmón $(\mathrm{OR}=0.32$, 95\% $\mathrm{CI}=$ 0.19-0.55) en la población noruega ${ }^{299}$. Una falta de asociación entre este polimorfismo y el riesgo de cáncer de pulmón se observo en la población danesa ${ }^{314}$, la población americana ${ }^{242}$, la población china ${ }^{315}$, y la población europea no fumadora ${ }^{294}$.

Los estudios realizados en población americana y china estudiaron la asociación entre este polimorfismo y el humo del tabaco. Cuando estratificaron por el hábito tabáquico, la interacción entre el tabaco y el polimorfismo no fue estadísticamente significativa. En el estudio chino también se estudió la interacción del polimorfismo con los diferentes subtipos de cáncer de pulmón, no encontrando diferencias estadísticamente significativas en el riesgo de acuerdo con los diferentes tipos histológicos. Igualmente no se observó asociación entre el polimorfismo C8092A y el riesgo de cáncer de pulmón en noruegos y americanos.

T19007 C (Asn118Asn) se ha estudiado en otros tipos de tumores, como el melanoma en el que no se encontró un mayor riesgo de desarrollar dicho tumor ${ }^{316}$, ó en los tumores cerebrales en donde si se ha encontrado asociación significativa ${ }^{317}$.

En nuestro estudio no se ha encontrado un mayor riesgo de cáncer de pulmón en función de las variantes del polimorfismo A19886G (Thr75) de ERCC1 (Tabla 101). Esto concuerda con los resultados de otros estudios en los que no se ha demostrado dicha asociación ${ }^{242}$, si bien en este estudio se estudiaron los dos polimorfismos 
comentados anteriormente, y el riesgo de asociación en los no fumadores era el doble respecto a los fumadores, indicando que polimorfismos en ERCC1 disminuyen la capacidad para la reparación del daño causado al DNA por el tabaco, modificando el riesgo de padecer cáncer de pulmón en función del numero de paquetes/año fumados.

De forma similar, existen estudios epidemiológicos que relacionan riesgo de desarrollar cáncer de pulmón en función de los polimorfismos en ERCC1 en función del tipo de raza, como ocurre con el polimorfismo Asn118Asn (G19007A) de ERCC1, asociado a un mayor riesgo de cáncer entre la raza caucásica, pero no a un mayor riesgo de cáncer de pulmón en la raza china ${ }^{318}$. Respecto al sexo, también se han encontrado diferencias, existiendo polimorfismos en ERCC1 asociados con un mayor riesgo de cáncer de pulmón especialmente en mujeres ${ }^{319}$.

En nuestro trabajo, al estudiar la relación entre las variables no genéticas -edad, número de paquetes / día y número de años fumando-, no hubo ninguna que se asociara con el ser portador de un genotipo específico en este SNP (Tablas 118-120). Estos dos últimos resultados concuerdan con los estudios de Zhou y Yin realizados en población americana y china, en donde la asociación entre el polimorfismo y el hábito tabáquico no fue estadísticamente significativa ${ }^{242,315}$.

Hemos determinado el riesgo de padecer cáncer considerando las variables anteriores. En la edad, el único coeficiente significativo es el correspondiente al grupo de edad [65-75], en el que la OR correspondiente es $>1$, es decir que individuos pertenecientes a este grupo de edad tienen más riesgo de padecer cáncer de pulmón (Tabla 152). En función del número de paquetes / día la única variable que resulta significativa es el número de paquetes al día que se fuma. La OR es $<1$, es decir que fumar más de un paquete al día es un factor de riesgo (Tabla 153). Considerando el número de años fumando la única variable que resulta significativa es el número de años fumando. La OR es >1, es decir que haber fumado más de 38 años es un factor de riesgo (Tabla 154). 
Al realizar el ajuste del modelo de regresión logística a partir de la introducción/eliminación progresiva de las variables genotipos en ERCC1: edad, número de paquetes/día y número de años fumando, la única variable que interviene es la edad y la única OR significativamente distinta de 1 es la correspondiente al intervalo de edad [65-75], siendo $>1$. Es decir, que individuos pertenecientes a este grupo de edad tienen más riesgo de padecer cáncer de pulmón (Tabla 155). Esto puede deberse a la relación que existe entre la edad y el número de años fumando.

Teniendo en cuenta todo lo dicho hasta ahora, podríamos considerar que uno de los problemas más importante frente a la investigación en cáncer de pulmón es identificar a las personas de alto riesgo para poder implantar programas de vigilancia, de prevención y de seguimiento. Las vías de reparación del DNA juegan un importante papel en el riesgo de cáncer de pulmón, y variaciones genéticas pueden contribuir a una menor capacidad para reparar el DNA y mayor susceptibilidad al cáncer de pulmón. Si bien el menor o mayor riesgo asociado con los SNPs es pequeño si lo comparamos con el producido por los genes de alta penetrancia, su implicación en la salud publica puede ser grande debido a su alta frecuencia en la población general. Es esencial que los estudios epidemiológicos sobre polimorfismos reparadores del DNA tengan un diseño adecuado. Desafortunadamente un buen número de estudios están limitados por su pequeño tamaño muestral y consecuentemente por el escaso poder para detectar efectos que pueden realmente existir. Igualmente los controles deberían de ser escogidos de tal manera que si fueran casos (por aparición del tumor), pudieran ser cruzados al grupo de casos. Es apropiado controlar los factores de confusión, especialmente la raza y el grupo étnico. Otra particularidad mayor es el grupo de genotipos para calcular la Odds Ratio (OR). Sin datos que nos permitan imponer cual es el grupo de genotipos, parece prudente calcular dos ORs por polimorfismo (uno para heterocigotos frente al alelo común homocigoto y otro para el alelo raro homocigoto frente al alelo común homocigoto) que nos permitan determinar el modelo dominante, codominante o recesivo. 
Los efectos de los polimorfismos están mejor representados por sus haplotipos. Datos de múltiples polimorfismos en un mismo gen pueden combinarse para crear haplotipos, el grupo de múltiples alelos en un mismo cromosoma. Ninguno de los estudios revisados informa asociación de haplotipos, incluso cuando varios de ellos analizan varios polimorfismos en un mismo gen. El análisis de haplotipos puede incrementar el poder para detectar asociaciones entre el polimorfismo y la enfermedad debido a la alta heterocigosidad y la escasa conexión entre las mutaciones que causan la enfermedad. Además, el análisis de haplotipos ofrece la ventaja de no asumir que ninguno de los genotipos polimórficos es funcional. Más allá, esto permite la posibilidad de una variante funcional no genotípica en desequilibrio con el polimorfismo.

En nuestro trabajo de tesis doctoral hemos tenido en cuenta todas estas particularidades a la hora de diseñar el estudio con el objetivo de minimizar al máximo todos los posibles factores de confusión y conseguir unos datos que nos permitieran extraer unos resultados consistentes. Aun así en dos polimorfismos del gen p53 (exón 4 e intron 3), al estratificar por edad no se cumple el equilibrio de Hardy-Weinberg. En el caso del exón 4 al tratarse de la muestra de casos podría ocurrir, como se comento anteriormente, que este polimorfismo estuviese alterado por la enfermedad. 


\section{6.- CONCLUSIONES}




\section{O N C L U S I O N E S}

1. La edad, el número de paquetes/día fumados y el número de años fumando son las variables no genéticas que se asocian a un mayor riesgo para desarrollar cáncer de pulmón.

2. Nuestros resultados muestran que el ser portador del alelo Arg en el codon 72 del gen TP53 disminuye la susceptibilidad a desarrollar cáncer de pulmón, mientras que ser portador del alelo Pro favorece el desarrollo de cáncer de pulmón a lo largo de la vida.

3. El ser portador del alelo 106bp del SNP P53 intrón 3 disminuye el riesgo de desarrollar cáncer de pulmón en individuos menores de 65 años.

4. En nuestro trabajo no hemos demostrado que este exista un mayor riesgo de desarrollar cáncer de pulmón en función de las diferentes variantes de los genes reparadores del ADN, XRCC1 y ERCC1. 


\section{7.- BIBLIOGRAFÍA}


1. Linnoila I. Pathology of non-small cell lung cancer. New diagnostic approaches. Hematol Oncol Clin North Am. 1990; 4(6): 1027-51.

2. Roggli V, Volmer R, Greenberg S. Lung cancer heterogeneity: a blinded and randomized study of 100 consecutive cases. Hum Pathol. 1985; 16: 569.

3. Travis W, Brambilla E, Müller-Hermelink H. Pathology and Genetics: Tumours of the Lung, Pleura, Thymus and Heart. Lyon: IARC; 2004.

4. Clayton F. The spectrum and significance of bronchioloalveolar carcinomas. Pathol Annu. 1988; 23 (Pt 2): 361-94.

5. Robert J, Everett E, Kenneth R. Non-Small Lung Cancer. In: DeVita C, Hellman S, Rosenberg S, eds. Cancer: Principles and practice of oncology. 6th ed. Philadelphia: Lippincott-Raven Publishers; 2001. p.925-982.

6. Parkin DM, Sankaranarayanan R. Overview on small cell lung cancer in the world: industrialized countries, Third World, Eastern Europe. Anticancer Res. 1994; 14(1B): 277-82.

7. U.S. Department of Health and Human Services. Reducing the health consequences of smoking: 25 years of progress. A report of the Surgeon General. Rockville: Center for Chronic Disease Prevention and Health Promotion, Office on Smoking and Health; 1989.

8. Guinee DG, Jr., Fishback NF, Koss MN, Abbondanzo SL, Travis WD. The spectrum of immunohistochemical staining of small-cell lung carcinoma in specimens from transbronchial and open-lung biopsies. Am J Clin Pathol. 1994; 102(4): 406-14. 
9. Travis WD, Linder J, Mackay B. Classification, histology, cytology, and electron microscopy. In: Pass HI, Mitchell JB, Johnson DH, et al., eds. Lung cancer: principles and practice. 2th ed. Philadelphia: Lippincott-Raven Publishers; 1996. p.231-240.

10. Agustí García-Navarro, R. Rosell Costa, E. Felip Fonti. Tumores Broncopulmonares. En: P. Farreras Valenti and C. Rozman editores. Medicina Interna.15th edición. Madrid: Elsevier; 2004. 1: p.780-792.

11. Parkin DM, Pisani P, Ferlay J. Global cancer statistics. CA Cancer J Clin. 1999; 49(1): 33-64.

12. Cancer facts and figures. Atlanta: American Cancer Society; 2000.

13. Coleman MP, Gatta G, Verdecchia A, Estève J, Sant M, Storm H, et al. EUROCARE-3 summary: cancer survival in Europe at the end of the 20th century. Annals of Oncology. 2003; 14 (Suppl 5): S128-149.

14. Berrino F, Gatta G, Chessa E, Valente F, Capocaccia R. The EUROCARE II study. Eur J Cancer. 1998; 34(14): 2139-53.

15. Centro Nacional Epidemiología. Mortalidad por Cáncer en España. Madrid: Área de Epidemiología Ambiental y Cáncer. Centro Nacional Epidemiología. Instituto de Salud Carlos III; 2000.

16. Lopez-Abente G, Pollan M, Aragones N, Perez Gomez B, Hernandez Barrera V, Lope V, et al. [State of cancer in Spain: incidence]. An Sist Sanit Navar. 2004; 27(2): 165-73. 
17. López - Abente Ortega G, Pollán Santamaría M, Aragonés Sanz N, Gómez Pérez B, Hernández Barrera V, Lope Carvajal V, et al. Informe sobre la salud de los españoles. Cáncer. Madrid: Área de epidemiología ambiental y cáncer. Centro nacional de epidemiología. Instituto de Salud Carlos III; 2003.

18. Wingo PA, Ries LA, Giovino GA, Miller DS, Rosenberg HM, Shopland DR, et al. Annual report to the nation on the status of cancer, 1973-1996, with a special section on lung cancer and tobacco smoking. J Natl Cancer Inst. 1999; 91(8): 675-90.

19. Castonguay A, Stoner GD, Schut HA, Hecht SS. Metabolism of tobacco-specific N-nitrosamines by cultured human tissues. Proc Natl Acad Sci U S A. 1983; 80(21): 6694-7.

20. Hecht SS, Hoffman D. Tobacco-specific nitrosamines: an important group of carcinogens in tobacco and tobacco smoke. Carcinogenesis. 1988; 9: 875.

21. Florin I, Rutberg L, Curvall M, Enzell CR. Screening of tobacco smoke constituents for mutagenicity using the Ames' test. Toxicology. 1980; 15(3): 21932.

22. Janerich DT, Thompson WD, Varela LR, Greenwald P, Chorost S, Tucci C, et al. Lung cancer and exposure to tobacco smoke in the household. N Engl J Med. 1990; 323(10): 632-6.

23. Phillips DH, Hewer A, Martin CN, Garner RC, King MM. Correlation of DNA adduct levels in human lung with cigarette smoking. Nature. 1988; 336(6201): 790-2.

24. Slebos RJ, Hruban RH, Dalesio O, Mooi WJ, Offerhaus GJ, Rodenhuis S. Relationship between K-ras oncogene activation and smoking in adenocarcinoma of the human lung. J Natl Cancer Inst. 1991; 83(14): 1024-7. 
25. Boots AW, Haenen GR, Bast A. Oxidant metabolism in chronic obstructive pulmonary disease. Eur Respir J Suppl. 2003; 46: 14-27.

26. Greenberg RA, Haley NJ, Etzel RA, Loda FA. Measuring the exposure of infants to tobacco smoke. Nicotine and cotinine in urine and saliva. N Engl J Med. 1984; 310(17): 1075-8.

27. Loganathan RS, Stover DE, Shi W, Venkatraman E. Prevalence of COPD in women compared to men around the time of diagnosis of primary lung cancer. Chest. 2006; 129(5): 1305-12.

28. Papi A, Casoni G, Caramori G, Guzzinati I, Boschetto P, Ravenna F, et al. COPD increases the risk of squamous histological subtype in smokers who develop nonsmall cell lung carcinoma. Thorax. 2004; 59(8): 679-81.

29. Wald NJ, Nanchahal K, Thompson SG, Cuckle HS. Does breathing other people's tobacco smoke cause lung cancer? Br Med J (Clin Res Ed). 1986; 293(6556): 1217-22.

30. Bartal M. COPD and tobacco smoke. Monaldi Arch Chest Dis. 2005; 63(4): 21325.

31. Yanbaeva DG, Dentener MA, Creutzberg EC, Wesseling G, Wouters EF. Systemic effects of smoking. Chest. 2007; 131(5): 1557-66.

32. The effect of vitamin $\mathrm{E}$ and beta carotene on the incidence of lung cancer and other cancers in male smokers. The Alpha-Tocopherol, Beta Carotene Cancer Prevention Study Group. N Engl J Med. 1994; 330(15): 1029-35.

33. Knekt P, Aromaa A, Maatela J, Alfthan G, Aaran RK, Hakama M, et al. Serum selenium and subsequent risk of cancer among Finnish men and women. J Natl Cancer Inst. 1990; 82(10): 864-8. 
34. Kvale G, Bjelke E, Gart JJ. Dietary habits and lung cancer risk. Int J Cancer. 1983; 31(4): 397-405.

35. Lippman SM, Benner SE, Hong WK. Cancer chemoprevention. J Clin Oncol. 1994; 12(4): 851-73.

36. Menkes MS, Comstock GW, Vuilleumier JP, Helsing KJ, Rider AA, Brookmeyer R. Serum beta-carotene, vitamins A and E, selenium, and the risk of lung cancer. N Engl J Med. 1986; 315(20): 1250-4.

37. Bolla M, Lefur R, Ton Van J, Domenge C, Badet JM, Koskas Y, et al. Prevention of second primary tumours with etretinate in squamous cell carcinoma of the oral cavity and oropharynx. Results of a multicentric double-blind randomised study. Eur J Cancer. 1994; 30A(6): 767-72.

38. Clark LC, Combs GF, Jr., Turnbull BW, Slate EH, Chalker DK, Chow J, et al. Effects of selenium supplementation for cancer prevention in patients with carcinoma of the skin. A randomized controlled trial. Nutritional Prevention of Cancer Study Group. JAMA. 1996; 276(24): 1957-63.

39. Greenberg ER, Sporn MB. Antioxidant vitamins, cancer, and cardiovascular disease. N Engl J Med. 1996; 334(18): 1189-90.

40. Hennekens CH, Buring JE, Manson JE, Stampfer M, Rosner B, Cook NR, et al. Lack of effect of long-term supplementation with beta carotene on the incidence of malignant neoplasms and cardiovascular disease. N Engl J Med. 1996; 334(18): 1145-9.

41. Lee JS, Lippman SM, Benner SE, Lee JJ, Ro JY, Lukeman JM, et al. Randomized placebo-controlled trial of isotretinoin in chemoprevention of bronchial squamous metaplasia. J Clin Oncol. 1994; 12(5): 937-45. 
42. Omenn GS, Goodman GE, Thornquist MD, Balmes J, Cullen MR, Glass A, et al. Effects of a combination of beta carotene and vitamin A on lung cancer and cardiovascular disease. N Engl J Med. 1996; 334(18): 1150-5.

43. Salonen JT, Alfthan G, Huttunen JK, Puska P. Association between serum selenium and the risk of cancer. Am J Epidemiol. 1984; 120(3): 342-9.

44. Shekelle RB, Lepper M, Liu S, Maliza C, Raynor WJ, Jr., Rossof AH, et al. Dietary vitamin A and risk of cancer in the Western Electric study. Lancet. 1981; 2(8257): 1185-90.

45. Stahelin HB, Gey KF, Eichholzer M, Ludin E. Beta-carotene and cancer prevention: the Basel Study. Am J Clin Nutr. 1991; 53(1 Suppl): S265-9.

46. Virtamo J. Vitamins and lung cancer. Proc Nutr Soc. 1999; 58(2): 329-33.

47. Willett WC, Polk BF, Underwood BA, Stampfer MJ, Pressel S, Rosner B, et al. Relation of serum vitamins $A$ and $E$ and carotenoids to the risk of cancer. $N$ Engl J Med. 1984; 310(7): 430-4.

48. Liu BQ, Peto R, Chen ZM, Boreham J, Wu YP, Li JY, et al. Emerging tobacco hazards in China: 1. Retrospective proportional mortality study of one million deaths. BMJ. 1998; 317(7170): 1411-22.

49. Masironi R, Rothwell K. Trends in and effects of smoking in the world. World Health Stat Q. 1988; 41(3-4): 228-41.

50. Pierce LM, Sivaraman L, Chang W, Lum A, Donlon T, Seifried A, et al. Relationships of TP53 codon 72 and HRAS1 polymorphisms with lung cancer risk in an ethnically diverse population. Cancer Epidemiol Biomarkers Prev. 2000; 9(11): 1199-204. 
51. Berry G, Newhouse ML, Antonis P. Combined effect of asbestos and smoking on mortality from lung cancer and mesothelioma in factory workers. Br J Ind Med. 1985; 42(1): 12-8.

52. Selikoff IJ, Seidman H, Hammond EC. Mortality effects of cigarette smoking among amosite asbestos factory workers. J Natl Cancer Inst. 1980; 65(3): 507-13.

53. Steenland K. Age specific interactions between smoking and radon among United States uranium miners. Occup Environ Med. 1994; 51(3): 192-4.

54. Peto R, López AD, Boreham J, Thun M, Heath C. Mortality from smoking in developed countries 1950-2000. Oxford: Oxford University Press; 1993.

55. Murray CJL, López AD. Alternative projections of mortality and disability by cause 1990-2020: Global Burden of Disease Study. Lancet. 1997; 349: 1498-504.

56. Tercer Plan de Actuación para una Europa sin Tabaco 1997-2001. Madrid: OMS (Oficina Regional para Europa) y Ministerio de Sanidad y Consumo; 1999.

57. Doll R, Peto R, Wheatley K, Gray R, Sutherland I. Mortality in relation to smoking: 40 years' observations on male British doctors. BMJ. 1994; 309(6959): 901-11.

58. Peto R. Smoking and death: the past 40 years and the next 40. BMJ. 1994; 309(6959): 937-9.

59. Ministerio de Sanidad y Consumo. Encuesta Nacional de Salud de España 1997. Madrid: Subdirección General de Epidemiología, Promoción y Educación para la Salud. Dirección General de Salud Pública. MSC; 1999.

60. Graham H. Smoking Prevalence among Women in the European Community 1950-1990. Soc Sci Med 1996; 43: 243-253. 
61. World Health Organization. The tobacco epidemic: a global public health emergency. Tobacco alert. Geneva: WHO; 1998.

62. Pardell Alentà H. Importancia social y sanitaria del tabaquismo. En: Organización Médica Colegial. Madrid. Manejo del fumador en la clínica. Recomendaciones para el médico español. Barcelona: Medicina stm Editores (Ars Medica); 2002. p.150-156.

63. Wyser C, Bolliger C. Smoking-Related disorders. The Tobacco Epidemic Prog Respir Res Basel Karger. 1997; 28: 78-106.

64. Banegas Banegas J, Díez Gañán L, Rodríguez-Artalejo F, González Enríquez J, Graciani Pérez-Regadera A, Villar Álvarez F. Mortalidad atribuible al tabaquismo en España en 1998. Med Clin (Barc). 2001; 117: 692-4.

65. González Enríquez J, Villar Álvarez F, Banegas Banegas J, Rodríguez Artalejo F, Martín Moreno J. Tendencia de la mortalidad atribuible al tabaquismo en España, 1978-1992: 600.000 muertes 15 años. Med Clin (Barc). 1997; 109: 577-82.

66. Cayuela A, Rodriguez-Dominguez S, Lopez-Campos JL, Vigil E, Otero R. Lung Cancer Mortality Trends in Spain Between 1980 and 2005. Arch Bronconeumol. 2008; 44(2): 70-4.

67. Nerín de la Puerta I, Guillén Gil D, Más Sánchez A. El tabaquismo como problema de salud pública. En: Barrueco Ferrero M, Hernández Mezquita MA (eds.). Manual de Prevención y Tratamiento del Tabaquismo. Madrid: Ergón ; 2003. p. 68-73.

68. World Health Organization. Tobacco or Health: A global status report. Geneva: WHO; 1997.

69. US Department of Health and Human Services. The health consequences of smoking cancer and chronic lung disease in the workplace. A report of the Surgeon General. Rockville: Office on smoking and health; 1985. 
70. Redmond DE, Jr. Tobacco and cancer: the first clinical report, 1761. N Engl J Med. 1970; 282(1): 18-23.

71. Fraser R. Enfermedad neoplásica de los pulmones. En: Fraser RG, Paré JP, Fraser RS, Paré PD, Eneraux G (eds.). Diagnóstico de las enfermedades del tórax. Buenos Aires: 3TM; 1992; 2: 1251.

72. Ochsner A, DeBakey M. Carcinoma of the lung. Arch Surg. 1941; 42: 209.

73. Lombard. Lombard HL, Doering CR. Cancer studies in Massachusetts: habits, characteristics, and environment of individuals with and without cancer. $\mathrm{N}$ Engl J Med. 1928; 198: 481.

74. Reagan R. Memorial to Dr. Alton Ochsner. J Thorac Cardiovasc Surg. 1982; 84(1): 3-10.

75. Doll R, Hill AB. Lung cancer and other causes of death in relation to smoking: second report on mortality of British doctors. Br Med J. 1956; 2: 1071.

76. Wynder EL, Graham EA. Tobacco smoking as a possible etiologic factor in bronchogenic carcinoma. JAMA. 1950; 143: 329.

77. Hammond EL, Horn D. Smoking and death rates: report on forty-four months of follow-up of 187,783 men. JAMA 1958; 166: 1294.

78. US Department of Health, Education, and Welfare. Smoking and health: report of the Advisory Committee to the Surgeon General. Atlanta: Centers for Disease Control (Public Health Service); 1964.

79. Grupo de trabajo de la SEPAR. Patología producida por el Consumo de Tabaco. En: Manuales SEPAR Vol. 1. Tabaquismo. Madrid: Grupo Aula Médica SA; 1995. 
80. Cardesa A. Carcinogenesi química i prevenció del cáncer. Real Academia de Medicina de Catalunya. Barcelona; 1993.

81. Hernández JR. Epidemiología. Carcinógenos (tabaco) y clasificación anatomopatológica. En: Carcinoma Broncogénico. Curso SEPAR. San Lorenzo de El Escorial; 1993.

82. Hecht SS. Tobacco smoke carcinogens and lung cancer. J Natl Cancer Inst. 1999; 91(14): 1194-210.

83. Uramoto H, Osaki T, Inoue M, Taga S, Takenoyama M, Hanagiri T, et al. Fas expression in non-small cell lung cancer: its prognostic effect in completely resected stage III patients. Eur J Cancer. 1999; 35(10): 1462-5.

84. Koh H, Geller AC. Cancer prevention: preventing tobacco-related cancers. In: DeVita C, Hellman S, Rosenberg S, eds. Cancer: Principles and practice of oncology. 7th ed. Philadelphia: Lippincott-Raven Publishers; 2005. p.493-506.

85. US Department of Health, Education, and Welfare. Smoking and health: a report of the surgeon general. Washington, DC: Public Health Service, Office of the Assistant Secretary for Health, Office on Smoking and Health; 1979.

86. Koh H, Kannler C, Geller A. Cancer prevention: preventing tobacco-related cancers. In: DeVita C, Hellman S, Rosenberg S, eds. Cancer: Principles and practice of oncology, 6th ed. Philadelphia: Lippincott-Raven Publishers; 2001. p. 490-503.

87. Mucha L, Stephenson J, Morandi N, Dirani R. Meta-analysis of disease risk associated with smoking, by gender and intensity of smoking. Gend Med. 2006; 3(4): 279-91.

88. Ozlu T, Bulbul Y. Smoking and lung cancer. Tuberk Toraks. 2005; 53(2): 200-9. 
89. Levi F. Cáncer Prevention: Epidemiology and Perspectives. Eur H Cancer. 1999; 35: 1912-1924.

90. Hofer I, Nil R, Wyss F, Battig K. The contributions of cigarette yield, consumption, inhalation and puffing behaviour to the prediction of smoke exposure. Clin Investig. 1992; 70(3-4): 343-51.

91. Sobradillo Peña V, Barrenechea Benguria JI. Patología relacionada con el tabaco. En: Jiménez Ruiz (ed.). Aproximación al tabaquismo en España. Madrid: Ergon; 1997.

92. Harris CC. Interindividual variation among humans in carcinogen metabolism, DNA adduct formation and DNA repair. Carcinogenesis. 1989; 10(9): 1563-6.

93. US Department of Health and Human Services. The health consequences of involuntary smoking: a report of the surgeon general. Washington, DC: Public Health Service, Centers for Disease Control, Office on Smoking and Health, Department of Health and Human Services; 1986. Pub. No. (CDC)87-8398.

94. Brownson RC, Eriksen MP, Davis RM, Warner KE. Environmental tobacco smoke: health effects and policies to reduce exposure. Annu Rev Public Health. 1997; 18: 163-85.

95. Carrion Valero F, Hernandez Hernandez JR. [Passive smoking in adults]. Arch Bronconeumol. 2002; 38(3): 137-46.

96. California Environmental Protection Agency. Health effects of exposure to environmental tobacco smoke. Tob Control. 1997; 6: 346.

97. Davis RM. Exposure to environmental tobacco smoke: identifying and protecting those at risk. JAMA. 1998; 280(22): 1947-9. 
98. US Environmental Protection Agency. Respiratory health effects of passive smoking: lung cancer and other disorders. Washington, DC: Environmental Protection Agency, Office of Air and Radiation; 1992. Pub. EPA/600/6-90/006F.

99. Taylor R, Najafi F, Dobson A. Meta-analysis of studies of passive smoking and lung cancer: effects of study type and continent. Int J Epidemiol. 2007; 36(5): 1048-59.

100. International Early Lung Cancer Program Investigators. An update of CT screening for lung cancer. Semin Ultrasound CT MR. 2005; 26(5): 348-56.

101. Alongi F, Ragusa P, Montemaggi P, Bona CM. Combining independent studies of diagnostic fluorodeoxyglucose positron-emission tomography and computed tomography in mediastinal lymph node staging for non-small cell lung cancer. Tumori. 2006; 92(4): 327-33.

102. Mountain CF. Revisions in the International System for Staging Lung Cancer. Chest. 1997; 111(6): 1710-7.

103. Graziano SL. Non-small cell lung cancer: clinical value of new biological predictors. Lung Cancer. 1997; 17 Suppl 1: S37-58.

104. Kwiatkowski DJ, Harpole DH, Jr., Godleski J, Herndon JE, 2nd, Shieh DB, Richards W, et al. Molecular pathologic substaging in 244 stage I non-small-cell lung cancer patients: clinical implications. J Clin Oncol. 1998; 16(7): 2468-77.

105. Linnoila RI, Piantadosi S, Ruckdeschel JC. Impact of neuroendocrine differentiation in non-small cell lung cancer. The LCSG experience. Chest. 1994; 106(6 Suppl): S367-71.

106. Mehdi SA, Tatum AH, Newman NB, Gamble GP, Etzell JE, Weidner N, et al. Prognostic markers in resected stage I and II non small-cell lung cancer: an analysis of 260 patients with 5 year follow-up. Clin Lung Cancer. 1999; 1(1): 5967; discussion 8-9.

Estudio de los polimorfismos de genes reparadores en población fumadora con y sin cáncer de pulmón 
107. Harpole DH, Jr., Herndon JE, 2nd, Wolfe WG, Iglehart JD, Marks JR. A prognostic model of recurrence and death in stage I non-small cell lung cancer utilizing presentation, histopathology, and oncoprotein expression. Cancer Res. 1995; 55(1): 51-6.

108. Salgia R, Skarin AT. Molecular abnormalities in lung cancer. J Clin Oncol. 1998; 16(3): 1207-17.

109. Strauss GM, Kwiatkowski DJ, Harpole DH, Lynch TJ, Skarin AT, Sugarbaker DJ. Molecular and pathologic markers in stage I non-small-cell carcinoma of the lung. J Clin Oncol. 1995; 13(5): 1265-79.

110. Volm M, Hahn EW, Mattern J, Muller T, Vogt-Moykopf I, Weber E. Five-year follow-up study of independent clinical and flow cytometric prognostic factors for the survival of patients with non-small cell lung carcinoma. Cancer Res. 1988; 48(10): 2923-8.

111. Zimmerman PV, Hawson GA, Bint MH, Parsons PG. Ploidy as a prognostic determinant in surgically treated lung cancer. Lancet. 1987; 2(8558): 530-3.

112. Chute CG, Greenberg ER, Baron J, Korson R, Baker J, Yates J. Presenting conditions of 1539 population-based lung cancer patients by cell type and stage in New Hampshire and Vermont. Cancer. 1985; 56(8): 2107-11.

113. Albain KS, Crowley JJ, LeBlanc M, Livingston RB. Determinants of improved outcome in small-cell lung cancer: an analysis of the 2,580-patient Southwest Oncology Group data base. J Clin Oncol. 1990; 8(9): 1563-74.

114. Dearing MP, Steinberg SM, Phelps R, Anderson MJ, Mulshine JL, Ihde DC, et al. Outcome of patients with small-cell lung cancer: effect of changes in staging procedures and imaging technology on prognostic factors over 14 years. J Clin Oncol. 1990; 8(6): 1042-9. 
115. Fizazi K, Cojean I, Pignon JP, Rixe O, Gatineau M, Hadef S, et al. Normal serum neuron specific enolase (NSE) value after the first cycle of chemotherapy: an early predictor of complete response and survival in patients with small cell lung carcinoma. Cancer. 1998; 82(6): 1049-55.

116. Jorgensen LG, Osterlind K, Genolla J, Gomm SA, Hernandez JR, Johnson PW, et al. Serum neuron-specific enolase (S-NSE) and the prognosis in small-cell lung cancer (SCLC): a combined multivariable analysis on data from nine centres. $\mathrm{Br} \mathrm{J}$ Cancer. 1996; 74(3): 463-7.

117. Osterlind K, Andersen PK. Prognostic factors in small cell lung cancer: multivariate model based on 778 patients treated with chemotherapy with or without irradiation. Cancer Res. 1986; 46(8): 4189-94.

118. Churchill E, Sweet R, Sutter L, al. e. Churchill ED, Sweet RH, Sutter L, et al. The surgical management of carcinoma of the lung: the study of cases treated at the Massachusetts General Hospital from 1930-50. J Thorac Cardiovasc Surg. 1950; 20:349.

119. Ginsberg RJ, Rubinstein LV. Randomized trial of lobectomy versus limited resection for T1 N0 non-small cell lung cancer. Lung Cancer Study Group. Ann Thorac Surg. 1995; 60(3): 615-22; discussion 22-3.

120. Martini N, Flehinger BJ. The role of surgery in N2 lung cancer. Surg Clin North Am. 1987; 67(5): 1037-49.

121. Naruke T, Goya T, Tsuchiya R, Suemasu K. The importance of surgery to nonsmall cell carcinoma of lung with mediastinal lymph node metastasis. Ann Thorac Surg. 1988; 46(6): 603-10.

122. Chemotherapy in non-small cell lung cancer: a meta-analysis using updated data on individual patients from 52 randomised clinical trials. Non-small Cell Lung Cancer Collaborative Group. BMJ. 1995; 311(7010): 899-909. 
123. Clinical practice guidelines for the treatment of unresectable non-small-cell lung cancer. Adopted on May 16, 1997 by the American Society of Clinical Oncology. J Clin Oncol. 1997; 15(8): 2996-3018.

124. Bunn PA, Jr., Kelly K. New chemotherapeutic agents prolong survival and improve quality of life in non-small cell lung cancer: a review of the literature and future directions. Clin Cancer Res. 1998; 4(5): 1087-100.

125. Grilli R, Oxman AD, Julian JA. Chemotherapy for advanced non-small-cell lung cancer: how much benefit is enough? J Clin Oncol. 1993; 11(10): 1866-72.

126. Johnson DH. Treatment strategies for metastatic non small-cell lung cancer. Clin Lung Cancer. 1999; 1(1): 34-41.

127. Marino P, Pampallona S, Preatoni A, Cantoni A, Invernizzi F. Chemotherapy vs supportive care in advanced non-small-cell lung cancer. Results of a metaanalysis of the literature. Chest. 1994; 106(3): 861-5.

128. Marino P, Preatoni A, Cantoni A. Randomized trials of radiotherapy alone versus combined chemotherapy and radiotherapy in stages IIIa and IIIb nonsmall cell lung cancer. A meta-analysis. Cancer. 1995; 76(4): 593-601.

129. Souquet PJ, Chauvin F, Boissel JP, Cellerino R, Cormier Y, Ganz PA, et al. Polychemotherapy in advanced non small cell lung cancer: a meta-analysis. Lancet. 1993; 342(8862): 19-21.

130. Vokes EE, Bitran JD. Non-small-cell lung cancer. Toward the next plateau. Chest. 1994; 106(3): 659-61.

131. Solomon B, Bunn PA, Jr. Adjuvant chemotherapy for non-small cell lung cancer. Cancer Invest. 2007; 25(4): 217-25. 
132. Delbaldo C, Michiels S, Syz N, Soria JC, Le Chevalier T, Pignon JP. Benefits of adding a drug to a single-agent or a 2-agent chemotherapy regimen in advanced non-small-cell lung cancer: a meta-analysis. JAMA. 2004; 292(4): 470-84.

133. Schiller JH, Harrington D, Belani CP, Langer C, Sandler A, Krook J, et al. Comparison of four chemotherapy regimens for advanced non-small-cell lung cancer. N Engl J Med. 2002; 346(2): 92-8.

134. Fossella FV, DeVore R, Kerr R. Phase II trial of docetaxel $100 \mathrm{mg} / \mathrm{m} 2$ or 75 $\mathrm{mg} / \mathrm{m} 2$ vs vinorelbine/ifosfamide for non-small cell lung cancer (NSCLC) previously treated with platinum-based chemotherapy (PBC). Proc Am Soc Clin Oncol. 1999; 18(abst 1776).

135. Shepherd F, Ramlau R, Mattson K. Randomized study of Taxotere (TAX) versus best supportive care (BSC) in non-small cell lung cancer (NSCLC) patients previously treated with platinum-based chemotherapy. Proc Am Soc Clin Oncol. 1999; 18:463a(abst 1784).

136. Siegfried JM, Weissfeld LA, Singh-Kaw P, Weyant RJ, Testa JR, Landreneau RJ. Association of immunoreactive hepatocyte growth factor with poor survival in resectable non-small cell lung cancer. Cancer Res. 1997; 57(3): 433-9.

137. Lynch TJ, Bell DW, Sordella R, Gurubhagavatula S, Okimoto RA, Brannigan $\mathrm{BW}$, et al. Activating mutations in the epidermal growth factor receptor underlying responsiveness of non-small-cell lung cancer to gefitinib. N Engl J Med. 2004; 350(21): 2129-39.

138. Rosell R, Cecere F, Cognetti F, Cuello M, Sanchez JM, Taron M, et al. Future directions in the second-line treatment of non-small cell lung cancer. Semin Oncol. 2006; 33(1 Suppl 1): S45-51.

139. Ruttinger D, Winter H, van den Engel NK, Hatz RA, Schlemmer M, Pohla H, et al. Immunotherapy of lung cancer: an update. Onkologie. 2006; 29(1-2): 33-8. 
140. Alverola V. ¿Es posible el tratamieto individualizado en el CPNM? Revisiones en Cáncer. 2005; 19(1): 81-85.

141. Olaussen KA, Dunant A, Fouret P, Brambilla E, Andre F, Haddad V, et al. DNA repair by ERCC1 in non-small-cell lung cancer and cisplatin-based adjuvant chemotherapy. N Engl J Med. 2006; 355(10): 983-91.

142. Pignon JP, Arriagada R, Ihde DC, Johnson DH, Perry MC, Souhami RL, et al. A meta-analysis of thoracic radiotherapy for small-cell lung cancer. N Engl J Med. 1992; 327(23): 1618-24.

143. Warde P, Payne D. Does thoracic irradiation improve survival and local control in limited-stage small-cell carcinoma of the lung? A meta-analysis. J Clin Oncol. 1992; 10(6): 890-5.

144. Turrisi AT, 3rd, Kim K, Blum R, Sause WT, Livingston RB, Komaki R, et al. Twice-daily compared with once-daily thoracic radiotherapy in limited small-cell lung cancer treated concurrently with cisplatin and etoposide. $\mathrm{N}$ Engl J Med. 1999; 340(4): 265-71.

145. Arriagada R. Re: Prophylactic cranial irradiation for patients with small-cell lung cancer. J Natl Cancer Inst. 1995; 87(10): 766; author reply 7.

146. Auperin A, Arriagada R, Pignon JP, Le Pechoux C, Gregor A, Stephens RJ, et al. Prophylactic cranial irradiation for patients with small-cell lung cancer in complete remission. Prophylactic Cranial Irradiation Overview Collaborative Group. N Engl J Med. 1999; 341(7): 476-84.

147. Girling DJ. Comparison of oral etoposide and standard intravenous multidrug chemotherapy for small-cell lung cancer: a stopped multicentre randomised trial. Medical Research Council Lung Cancer Working Party. Lancet. 1996; 348(9027): 563-6. 
148. Souhami RL, Spiro SG, Rudd RM, Ruiz de Elvira MC, James LE, Gower NH, et al. Five-day oral etoposide treatment for advanced small-cell lung cancer: randomized comparison with intravenous chemotherapy. J Natl Cancer Inst. 1997; 89(8): 577-80.

149. Murren J, Glatstein E, Pass HI. Small Cell Lung Cancer. In: DeVita C, Hellman S, Rosenberg S, eds. Cancer: Principles and practice of oncology. 6th ed. Philadelphia: Lippincott-Raven Publishers; 2001. p.983-1018.

150. Noda K, Nishiwaki Y, Kawahara M, Negoro S, Sugiura T, Yokoyama A, et al. Irinotecan plus cisplatin compared with etoposide plus cisplatin for extensive small-cell lung cancer. N Engl J Med. 2002; 346(2): 85-91.

151. Hanna N, Bunn PA, Jr., Langer C, Einhorn L, Guthrie T, Jr., Beck T, et al. Randomized phase III trial comparing irinotecan/cisplatin with etoposide/cisplatin in patients with previously untreated extensive-stage disease small-cell lung cancer. J Clin Oncol. 2006; 24(13): 2038-43.

152. Hanahan D, Weinberg RA. The hallmarks of cancer. Cell. 2000; 100(1): 57-70.

153. Lukashev ME, Werb Z. ECM signalling: orchestrating cell behaviour and misbehaviour. Trends Cell Biol. 1998; 8(11): 437-41.

154. Levine AJ. p53, the cellular gatekeeper for growth and division. Cell. 1997; 88(3): 323-31.

155. Wright WE, Pereira-Smith OM, Shay JW. Reversible cellular senescence: implications for immortalization of normal human diploid fibroblasts. Mol Cell Biol. 1989; 9(7): 3088-92.

156. Stetler-Stevenson WG. Matrix metalloproteinases in angiogenesis: a moving target for therapeutic intervention. J Clin Invest. 1999; 103(9): 1237-41. 
157. Varner JA, Cheresh DA. Integrins and cancer. Curr Opin Cell Biol. 1996; 8(5): 724-30.

158. Christofori G, Semb H. The role of the cell-adhesion molecule E-cadherin as a tumour-suppressor gene. Trends Biochem Sci. 1999; 24(2): 73-6.

159. Chambers AF, Matrisian LM. Changing views of the role of matrix metalloproteinases in metastasis. J Natl Cancer Inst. 1997; 89(17): 1260-70.

160. Powell WC, Matrisian LM. Complex roles of matrix metalloproteinases in tumor progression. Curr Top Microbiol Immunol. 1996; 213 (Pt 1): 1-21.

161. Stetler-Stevenson WG, Yu AE. Proteases in invasion: matrix metalloproteinases. Semin Cancer Biol. 2001; 11(2): 143-52.

162. Boyer B, Valles AM, Thiery JP. Model systems of carcinoma cell dispersion. Curr Top Microbiol Immunol. 1996; 213 (Pt 1): 179-94.

163. Silletti S, Raz A. Regulation of autocrine motility factor receptor expression in tumor cell locomotion and metastasis. Curr Top Microbiol Immunol. 1996; 213 (Pt 2): 137-69.

164. Rusch V, Klimstra D, Venkatraman E, Pisters PW, Langenfeld J, Dmitrovsky E. Overexpression of the epidermal growth factor receptor and its ligand transforming growth factor alpha is frequent in resectable non-small cell lung cancer but does not predict tumor progression. Clin Cancer Res. 1997; 3(4): 51522.

165. Tsai CM, Chang KT, Wu LH, Chen JY, Gazdar AF, Mitsudomi T, et al. Correlations between intrinsic chemoresistance and HER-2/neu gene expression, p53 gene mutations, and cell proliferation characteristics in non-small cell lung cancer cell lines. Cancer Res. 1996; 56(1): 206-9. 
166. Kelley MJ, Linnoila RI, Avis IL, Georgiadis MS, Cuttitta F, Mulshine JL, et al. Antitumor activity of a monoclonal antibody directed against gastrin-releasing peptide in patients with small cell lung cancer. Chest. 1997; 112(1): 256-61.

167. Richardson GE, Johnson BE. The biology of lung cancer. Semin Oncol. 1993; 20(2): 105-27.

168. Rosell R, Li S, Skacel Z, Mate JL, Maestre J, Canela M, et al. Prognostic impact of mutated K-ras gene in surgically resected non-small cell lung cancer patients. Oncogene. 1993; 8(9): 2407-12.

169. Graziano SL, Gamble GP, Newman NB, Abbott LZ, Rooney M, Mookherjee S, et al. Prognostic significance of K-ras codon 12 mutations in patients with resected stage I and II non-small-cell lung cancer. J Clin Oncol. 1999; 17(2): 66875.

170. Huncharek M, Muscat J, Geschwind JF. K-ras oncogene mutation as a prognostic marker in non-small cell lung cancer: a combined analysis of 881 cases. Carcinogenesis. 1999; 20(8): 1507-10.

171. Rodenhuis S, Boerrigter L, Top B, Slebos RJ, Mooi WJ, van't Veer L, et al. Mutational activation of the K-ras oncogene and the effect of chemotherapy in advanced adenocarcinoma of the lung: a prospective study. J Clin Oncol. 1997; 15(1): 285-91.

172. Sekido Y, Fong KM, Minna JD. Progress in understanding the molecular pathogenesis of human lung cancer. Biochim Biophys Acta. 1998; 1378(1): 2159.

173. Wang SS, Esplin ED, Li JL, Huang L, Gazdar A, Minna J, et al. Alterations of the PPP2R1B gene in human lung and colon cancer. Science. 1998; 282(5387): 284-7. 
174. Allred DC, Elledge R, Clark GM, Fuqua SA. The p53 tumor-suppressor gene in human breast cancer. Cancer Treat Res. 1994; 71: 63-77.

175. van Oijen MG, Slootweg PJ. Gain-of-function mutations in the tumor suppressor gene p53. Clin Cancer Res. 2000; 6(6): 2138-45.

176. Cox LS, Lane DP. Tumour suppressors, kinases and clamps: how p53 regulates the cell cycle in response to DNA damage. Bioessays. 1995; 17(6): 501-8.

177. Elledge RM, Lee WH. Life and death by p53. Bioessays. 1995; 17(11): 923-30.

178. Chen X. The p53 family: same response, different signals? Mol Med Today. 1999; 5(9): 387-92.

179. Bennett WP, Hussain SP, Vahakangas KH, Khan MA, Shields PG, Harris CC. Molecular epidemiology of human cancer risk: gene-environment interactions and p53 mutation spectrum in human lung cancer. J Pathol. 1999; 187(1): 8-18.

180. Tammemagi MC, McLaughlin JR, Bull SB. Meta-analyses of p53 tumor suppressor gene alterations and clinicopathological features in resected lung cancers. Cancer Epidemiol Biomarkers Prev. 1999; 8(7): 625-34.

181. Denissenko MF, Pao A, Tang M, Pfeifer GP. Preferential formation of benzo[a]pyrene adducts at lung cancer mutational hotspots in P53. Science. 1996; 274(5286): 430-2.

182. Lubin R, Zalcman G, Bouchet L, Tredanel J, Legros Y, Cazals D, et al. Serum p53 antibodies as early markers of lung cancer. Nat Med. 1995; 1(7): 701-2.

183. Zalcman G, Schlichtholz B, Tredaniel J, Urban T, Lubin R, Dubois I, et al. Monitoring of p53 autoantibodies in lung cancer during therapy: relationship to response to treatment. Clin Cancer Res. 1998; 4(6): 1359-66. 
184. Mitsudomi T, Suzuki S, Yatabe Y, Nishio M, Kuwabara M, Gotoh K, et al. Clinical implications of p53 autoantibodies in the sera of patients with non-smallcell lung cancer. J Natl Cancer Inst. 1998; 90(20): 1563-8.

185. Roth JA, Nguyen D, Lawrence DD, Kemp BL, Carrasco CH, Ferson DZ, et al. Retrovirus-mediated wild-type p53 gene transfer to tumors of patients with lung cancer. Nat Med. 1996; 2(9): 985-91.

186. Swisher SG, Roth JA, Nemunaitis J, Lawrence DD, Kemp BL, Carrasco CH, et al. Adenovirus-mediated p53 gene transfer in advanced non-small-cell lung cancer. J Natl Cancer Inst. 1999; 91(9): 763-71.

187. Hainaut P, Hollstein M. p53 and human cancer: the first ten thousand mutations. Adv Cancer Res. 2000; 77: 81-137.

188. Soussi T, Caron de Fromentel C, May P. Structural aspects of the p53 protein in relation to gene evolution. Oncogene. 1990; 5(7): 945-52.

189. Dittmer D, Pati S, Zambetti G, Chu S, Teresky AK, Moore M, et al. Gain of function mutations in p53. Nat Genet. 1993; 4(1): 42-6.

190. Iggo R, Gatter K, Bartek J, Lane D, Harris AL. Increased expression of mutant forms of p53 oncogene in primary lung cancer. Lancet. 1990; 335(8691): 675-9.

191. Greenblatt MS, Bennett WP, Hollstein M, Harris CC. Mutations in the p53 tumor suppressor gene: clues to cancer etiology and molecular pathogenesis. Cancer Res. 1994; 54(18): 4855-78.

192. Hollstein M, Rice K, Greenblatt MS, Soussi T, Fuchs R, Sorlie T, et al. Database of p53 gene somatic mutations in human tumors and cell lines. Nucleic Acids Res. 1994; 22(17): 3551-5.

193. Wood RD, Mitchell M, Lindahl T. Human DNA repair genes, 2005. Mutat Res. 2005; 577(1-2): 275-83. 
194. Fan R, Wu MT, Miller D, Wain JC, Kelsey KT, Wiencke JK, et al. The p53 codon 72 polymorphism and lung cancer risk. Cancer Epidemiol Biomarkers Prev. 2000; 9(10): 1037-42.

195. Shen MR, Jones IM, Mohrenweiser H. Nonconservative amino acid substitution variants exist at polymorphic frequency in DNA repair genes in healthy humans. Cancer Res. 1998; 58(4): 604-8.

196. Cleaver JE. Defective repair replication of DNA in xeroderma pigmentosum. Nature. 1968; 218(5142): 652-6.

197. de Boer J, Hoeijmakers JH. Nucleotide excision repair and human syndromes. Carcinogenesis. 2000; 21(3): 453-60.

198. Bignami M, Casorelli I, Karran P. Mismatch repair and response to DNAdamaging antitumour therapies. Eur J Cancer. 2003; 39(15): 2142-9.

199. Lindahl T, Wood RD. Quality control by DNA repair. Science. 1999; 286(5446): 1897-905.

200. Matullo G, Guarrera S, Carturan S, Peluso M, Malaveille C, Davico L, et al. DNA repair gene polymorphisms, bulky DNA adducts in white blood cells and bladder cancer in a case-control study. Int J Cancer. 2001; 92(4): 562-7.

201. Haber JE. Partners and pathwaysrepairing a double-strand break. Trends Genet. 2000; 16(6): 259-64.

202. Khanna KK, Jackson SP. DNA double-strand breaks: signaling, repair and the cancer connection. Nat Genet. 2001; 27(3): 247-54.

203. de Laat WL, Jaspers NG, Hoeijmakers JH. Molecular mechanism of nucleotide excision repair. Genes Dev. 1999; 13(7): 768-85. 
204. Friedberg EC. How nucleotide excision repair protects against cancer. Nat Rev Cancer. 2001; 1(1): 22-33.

205. Park CH, Mu D, Reardon JT, Sancar A. The general transcription-repair factor TFIIH is recruited to the excision repair complex by the XPA protein independent of the TFIIE transcription factor. J Biol Chem. 1995; 270(9): 4896-902.

206. Iyer N, Reagan MS, Wu KJ, Canagarajah B, Friedberg EC. Interactions involving the human RNA polymerase II transcription/nucleotide excision repair complex TFIIH, the nucleotide excision repair protein XPG, and Cockayne syndrome group B (CSB) protein. Biochemistry. 1996; 35(7): 2157-67.

207. Bennett P. Demystified. microsatellites. Mol Pathol. 2000; 53(4): 177-83.

208. Botstein D, White RL, Skolnick M, Davis RW. Construction of a genetic linkage map in man using restriction fragment length polymorphisms. Am J Hum Genet. 1980; 32(3): 314-31.

209. Schork NJ, Fallin D, Lanchbury JS. Single nucleotide polymorphisms and the future of genetic epidemiology. Clin Genet. 2000; 58(4): 250-64.

210. Sunyaev S, Ramensky V, Koch I, Lathe W, 3rd, Kondrashov AS, Bork P. Prediction of deleterious human alleles. Hum Mol Genet. 2001; 10(6): 591-7.

211. Willems PM, Meyerink JP, van de Locht LT, Smetsers TF, de Vries N, Mensink EJ. PCR detection of a BglII polymorphism in intron I of the human p53 gene (TP53). Nucleic Acids Res. 1992; 20(5): 1172.

212. Felley-Bosco E, Weston A, Cawley HM, Bennett WP, Harris CC. Functional studies of a germ-line polymorphism at codon 47 within the p53 gene. Am J Hum Genet. 1993; 53(3): 752-9. 
213. Thomas R, Kaplan L, Reich N, Lane DP, Levine AJ. Characterization of human p53 antigens employing primate specific monoclonal antibodies. Virology. 1983; 131(2): 502-17.

214. Matlashewski GJ, Tuck S, Pim D, Lamb P, Schneider J, Crawford LV. Primary structure polymorphism at amino acid residue 72 of human p53. Mol Cell Biol. 1987; 7(2): 961-3.

215. McDaniel T, Carbone D, Takahashi T, Chumakov P, Chang EH, Pirollo KF, et al. The MspI polymorphism in intron 6 of p53 (TP53) detected by digestion of PCR products. Nucleic Acids Res. 1991; 19(17): 4796.

216. Lehman TA, Haffty BG, Carbone CJ, Bishop LR, Gumbs AA, Krishnan S, et al. Elevated frequency and functional activity of a specific germ-line p53 intron mutation in familial breast cancer. Cancer Res. 2000; 60(4): 1062-9.

217. Papadakis ED, Soulitzis N, Spandidos DA. Association of p53 codon 72 polymorphism with advanced lung cancer: the Arg allele is preferentially retained in tumours arising in Arg/Pro germline heterozygotes. Br J Cancer. 2002; 87(9): 1013-8.

218. Hu Y, McDermott MP, Ahrendt SA. The p53 codon 72 proline allele is associated with p53 gene mutations in non-small cell lung cancer. Clin Cancer Res. 2005; 11(7): 2502-9.

219. Irarrazabal CE, Rojas C, Aracena R, Marquez C, Gil L. Chilean pilot study on the risk of lung cancer associated with codon 72 polymorphism in the gene of protein p53. Toxicol Lett. 2003; 144(1): 69-76.

220. Kawajiri K, Nakachi K, Imai K, Watanabe J, Hayashi S. Germ line polymorphisms of p53 and CYP1A1 genes involved in human lung cancer. Carcinogenesis. 1993; 14(6): 1085-9. 
221. Liu G, Miller DP, Zhou W, Thurston SW, Fan R, Xu LL, et al. Differential association of the codon 72 p53 and GSTM1 polymorphisms on histological subtype of non-small cell lung carcinoma. Cancer Res. 2001; 61(24): 8718-22.

222. Miller DP, Liu G, De Vivo I, Lynch TJ, Wain JC, Su L, et al. Combinations of the variant genotypes of GSTP1, GSTM1, and p53 are associated with an increased lung cancer risk. Cancer Res. 2002; 62(10): 2819-23.

223. Ueda M, Hung YC, Terai Y, Kanda K, Takehara M, Yamashita H, et al. Glutathione S-transferase GSTM1, GSTT1 and p53 codon 72 polymorphisms in human tumor cells. Hum Cell. 2003; 16(4): 241-51.

224. Weston A, Perrin LS, Forrester K, Hoover RN, Trump BF, Harris CC, et al. Allelic frequency of a p53 polymorphism in human lung cancer. Cancer Epidemiol Biomarkers Prev. 1992; 1(6): 481-3.

225. Biros E, Kalina I, Biros I, Kohut A, Bogyiova E, Salagovic J, et al. Polymorphism of the p53 gene within the codon 72 in lung cancer patients. Neoplasma. 2001; 48(5): 407-11.

226. Malcolm EK, Baber GB, Boyd JC, Stoler MH. Polymorphism at codon 72 of p53 is not associated with cervical cancer risk. Mod Pathol. 2000; 13(4): 373-8.

227. Su L, Sai Y, Fan R, Thurston SW, Miller DP, Zhou W, et al. P53 (codon 72) and P21 (codon 31) polymorphisms alter in vivo mRNA expression of p21. Lung Cancer. 2003; 40(3): 259-66.

228. Zhang JH, Li Y, Wang R, Wen DG, Wu ML, He M. [p53 gene polymorphism with susceptibility to esophageal cancer and lung cancer in Chinese population]. Zhonghua Zhong Liu Za Zhi. 2003; 25(4): 365-7.

229. Birgander R, Sjalander A, Rannug A, Alexandrie AK, Sundberg MI, Seidegard J, et al. P53 polymorphisms and haplotypes in lung cancer. Carcinogenesis. 1995; 16(9): 2233-6. 
230. Lazar V, Hazard F, Bertin F, Janin N, Bellet D, Bressac B. Simple sequence repeat polymorphism within the p53 gene. Oncogene. 1993; 8(6): 1703-5.

231. Wu X, Zhao H, Amos CI, Shete S, Makan N, Hong WK, et al. p53 Genotypes and Haplotypes Associated With Lung Cancer Susceptibility and Ethnicity. J Natl Cancer Inst. 2002; 94(9): 681-90.

232. Matakidou A, Eisen T, Houlston RS. TP53 polymorphisms and lung cancer risk: a systematic review and meta-analysis. Mutagenesis. 2003; 18(4): 377-85.

233. Berwick M, Vineis P. Markers of DNA repair and susceptibility to cancer in humans: an epidemiologic review. J Natl Cancer Inst. 2000; 92(11): 874-97.

234. Lippman SM, Spitz MR. Lung cancer chemoprevention: an integrated approach. J Clin Oncol. 2001; 19(18 Suppl): S74-82.

235. Rajaee-Behbahani N, Schmezer P, Risch A, Rittgen W, Kayser KW, Dienemann $\mathrm{H}$, et al. Altered DNA repair capacity and bleomycin sensitivity as risk markers for non-small cell lung cancer. Int J Cancer. 2001; 95(2): 86-91.

236. Wei Q, Cheng L, Amos CI, Wang LE, Guo Z, Hong WK, et al. Repair of tobacco carcinogen-induced DNA adducts and lung cancer risk: a molecular epidemiologic study. J Natl Cancer Inst. 2000; 92(21): 1764-72.

237. Wei Q, Cheng L, Hong WK, Spitz MR. Reduced DNA repair capacity in lung cancer patients. Cancer Res. 1996; 56(18): 4103-7.

238. Ford BN, Ruttan CC, Kyle VL, Brackley ME, Glickman BW. Identification of single nucleotide polymorphisms in human DNA repair genes. Carcinogenesis. 2000; 21(11): 1977-81.

239. Hung RJ, Brennan P, Canzian F, Szeszenia-Dabrowska N, Zaridze D, Lissowska $\mathrm{J}$, et al. Large-scale investigation of base excision repair genetic polymorphisms 
and lung cancer risk in a multicenter study. J Natl Cancer Inst. 2005; 97(8): 56776.

240. Hung RJ, Hall J, Brennan P, Boffetta P. Genetic polymorphisms in the base excision repair pathway and cancer risk: a HuGE review. Am J Epidemiol. 2005; 162(10): 925-42.

241. Park JY, Lee SY, Jeon HS, Bae NC, Chae SC, Joo S, et al. Polymorphism of the DNA repair gene XRCC1 and risk of primary lung cancer. Cancer Epidemiol Biomarkers Prev. 2002; 11(1): 23-7.

242. Zhou W, Liu G, Park S, Wang Z, Wain JC, Lynch TJ, et al. Gene-smoking interaction associations for the ERCC1 polymorphisms in the risk of lung cancer. Cancer Epidemiol Biomarkers Prev. 2005; 14(2): 491-6.

243. Casse C, Hu YC, Ahrendt SA. The XRCC1 codon 399 Gln allele is associated with adenine to guanine p53 mutations in non-small cell lung cancer. Mutat Res. 2003; 528(1-2): 19-27.

244. Yu JJ, Mu C, Lee KB, Okamoto A, Reed EL, Bostick-Bruton F, et al. A nucleotide polymorphism in ERCC1 in human ovarian cancer cell lines and tumor tissues. Mutat Res. 1997; 382(1-2): 13-20.

245. To-Figueras J, Gene M, Gomez-Catalan J, Galan C, Firvida J, Fuentes M, et al. Glutathione-S-Transferase M1 and codon 72 p53 polymorphisms in a northwestern Mediterranean population and their relation to lung cancer susceptibility. Cancer Epidemiol Biomarkers Prev. 1996; 5(5): 337-42.

246. SEER Cancer statistics review [sede Web]. Maryland: National Cancer Institute; 2005 [acceso el 21 de Noviembre de 2007]. Lung and bronchus cancer (invasive). Trends in SEER incidencea and U.S mortality using the joinpoint regression program, 1975-2004 with up to three joinpoints by race and sex. Disponible en: http://seer.cancer.gov/csr/1975_2004/results_merged/sect_15_lung_bronchus.pdf 
247. Blanc PD, Toren K. Occupation in chronic obstructive pulmonary disease and chronic bronchitis: an update. Int J Tuberc Lung Dis. 2007; 11(3): 251-7.

248. Rohde G. [The effects of air pollution and climate change on pulmonary diseases]. Dtsch Med Wochenschr. 2008; 133(14): 733-6.

249. Sint T, Donohue JF, Ghio AJ. Ambient air pollution particles and the acute exacerbation of chronic obstructive pulmonary disease. Inhal Toxicol. 2008; 20(1): 25-9.

250. Viegi G, Maio S, Pistelli F, Baldacci S, Carrozzi L. Epidemiology of chronic obstructive pulmonary disease: health effects of air pollution. Respirology. 2006; 11(5): 523-32.

251. Chen JX, Zheng Y, West M, Tang MS. Carcinogens preferentially bind at methylated CpG in the p53 mutational hot spots. Cancer Res. 1998; 58(10): 20705.

252. Smith LE, Denissenko MF, Bennett WP, Li H, Amin S, Tang M, et al. Targeting of lung cancer mutational hotspots by polycyclic aromatic hydrocarbons. J Natl Cancer Inst. 2000; 92(10): 803-11.

253. Chou KM, Cheng YC. An exonucleolytic activity of human apurinic/apyrimidinic endonuclease on 3' mispaired DNA. Nature. 2002; 415(6872): 655-9.

254. Hussain SP, Amstad P, Raja K, Sawyer M, Hofseth L, Shields PG, et al. Mutability of p53 hotspot codons to benzo(a)pyrene diol epoxide (BPDE) and the frequency of p53 mutations in nontumorous human lung. Cancer Res. 2001; 61(17): 6350-5.

255. Nilsen H, Krokan HE. Base excision repair in a network of defence and tolerance. Carcinogenesis. 2001; 22(7): 987-98. 
256. Ahrendt SA, Chow JT, Yang SC, Wu L, Zhang MJ, Jen J, et al. Alcohol consumption and cigarette smoking increase the frequency of p53 mutations in non-small cell lung cancer. Cancer Res. 2000; 60(12): 3155-9.

257. Lloyd DR, Hanawalt PC. p53-dependent global genomic repair of benzo[a]pyrene-7,8-diol-9,10-epoxide adducts in human cells. Cancer Res. 2000; 60(3): 517-21.

258. Dumont P, Leu JI, Della Pietra AC, 3rd, George DL, Murphy M. The codon 72 polymorphic variants of p53 have markedly different apoptotic potential. Nat Genet. 2003; 33(3): 357-65.

259. Langerod A, Bukholm IR, Bregard A, Lonning PE, Andersen TI, Rognum TO, et al. The TP53 codon 72 polymorphism may affect the function of TP53 mutations in breast carcinomas but not in colorectal carcinomas. Cancer Epidemiol Biomarkers Prev. 2002; 11(12): 1684-8.

260. Tada M, Furuuchi K, Kaneda M, Matsumoto J, Takahashi M, Hirai A, et al. Inactivate the remaining p53 allele or the alternate p73? Preferential selection of the Arg72 polymorphism in cancers with recessive p53 mutants but not transdominant mutants. Carcinogenesis. 2001; 22(3): 515-7.

261. Kalemi TG, Lambropoulos AF, Gueorguiev M, Chrisafi S, Papazisis KT, Kotsis A. The association of p53 mutations and p53 codon 72, Her 2 codon 655 and MTHFR C677T polymorphisms with breast cancer in Northern Greece. Cancer Lett. 2005; 222(1): 57-65.

262. Huang XE, Hamajima N, Katsuda N, Matsuo K, Hirose K, Mizutani M, et al. Association of p53 codon Arg72Pro and p73 G4C14-to-A4T14 at exon 2 genetic polymorphisms with the risk of Japanese breast cancer. Breast Cancer. 2003; 10(4): 307-11. 
263. Weston A, Ling-Cawley HM, Caporaso NE, Bowman ED, Hoover RN, Trump $\mathrm{BF}$, et al. Determination of the allelic frequencies of an L-myc and a p53 polymorphism in human lung cancer. Carcinogenesis. 1994; 15(4): 583-7.

264. Weston A, Godbold JH. Polymorphisms of H-ras-1 and p53 in breast cancer and lung cancer: a meta-analysis. Environ Health Perspect. 1997; 105 Suppl 4: 91926.

265. Wu HC, Chang CH, Chen HY, Tsai FJ, Tsai JJ, Chen WC. p53 gene codon 72 polymorphism but not tumor necrosis factor-alpha gene is associated with prostate cancer. Urol Int. 2004; 73(1): 41-6.

266. Huang SP, Wu WJ, Chang WS, Wu MT, Chen YY, Chen YJ, et al. p53 Codon 72 and p21 codon 31 polymorphisms in prostate cancer. Cancer Epidemiol Biomarkers Prev. 2004; 13(12): 2217-24.

267. Chen YC, Xu L, Guo YL, Su HJ, Smith TJ, Ryan LM, et al. Polymorphisms in GSTT1 and p53 and urinary transitional cell carcinoma in south-western Taiwan: a preliminary study. Biomarkers. 2004; 9(4-5): 386-94.

268. Mabrouk I, Baccouche S, El-Abed R, Mokdad-Gargouri R, Mosbah A, Said S, et al. No evidence of correlation between p53 codon 72 polymorphism and risk of bladder or breast carcinoma in Tunisian patients. Ann N Y Acad Sci. 2003; 1010: 764-70.

269. Furihata M, Takeuchi T, Matsumoto M, Kurabayashi A, Ohtsuki Y, Terao N, et al. p53 mutation arising in Arg72 allele in the tumorigenesis and development of carcinoma of the urinary tract. Clin Cancer Res. 2002; 8(5): 1192-5.

270. Kucera E, Tong D, Reinthaller A, Leodolter S, Zeillinger R, Sliutz G. p53 polymorphism at codon 72--does it constitute a risk for squamous intraepithelial lesions and invasive cancer of the cervix in Central Europeans? Wien Klin Wochenschr. 2000; 112(18): 817-20. 
271. Sifuentes Alvarez A, Reyes Romero M. [Risk factors for cervico-uterine cancer associated to HPV: p53 codon 72 polymorphism in women attending hospital care]. Ginecol Obstet Mex. 2003; 71: 12-5.

272. Wu MT, Liu CL, Ho CK, Wu TN. Genetic polymorphism of p53 and XRCC1 in cervical intraepithelial neoplasm in Taiwanese women. J Formos Med Assoc. 2004; 103(5): 337-43.

273. Roh JW, Kim JW, Park NH, Song YS, Park IA, Park SY, et al. p53 and p21 genetic polymorphisms and susceptibility to endometrial cancer. Gynecol Oncol. 2004; 93(2): 499-505.

274. Hogdall EV, Hogdall CK, Christensen L, Glud E, Blaakaer J, Bock JE, et al. Distribution of p53 codon 72 polymorphisms in ovarian tumour patients and their prognostic significance in ovarian cancer patients. Anticancer Res. 2002; 22(3): 1859-64.

275. Pegoraro RJ, Moodley M, Rom L, Chetty R, Moodley J. P53 codon 72 polymorphism and BRCA 1 and 2 mutations in ovarian epithelial malignancies in black South Africans. Int J Gynecol Cancer. 2003; 13(4): 444-9.

276. Shepherd T, Tolbert D, Benedetti J, Macdonald J, Stemmermann G, Wiest J, et al. Alterations in exon 4 of the p53 gene in gastric carcinoma. Gastroenterology. 2000; 118(6): 1039-44.

277. Wu MT, Chen MC, Wu DC. Influences of lifestyle habits and p53 codon 72 and p21 codon 31 polymorphisms on gastric cancer risk in Taiwan. Cancer Lett. 2004; 205(1): 61-8.

278. Verheijen FM, Sprong M, Kloosterman JM, Blaauw G, Thijssen JH, Blankenstein MA. TP53 mutations in human meningiomas. Int J Biol Markers. 2002; 17(1): 42-8. 
279. de Oliveira WR, Rady PL, Grady J, Hughes TK, Neto CF, Rivitti EA, et al. Association of p53 arginine polymorphism with skin cancer. Int J Dermatol. 2004; 43(7): 489-93.

280. Wang YC, Chen CY, Chen SK, Chang YY, Lin P. p53 codon 72 polymorphism in Taiwanese lung cancer patients: association with lung cancer susceptibility and prognosis. Clin Cancer Res. 1999; 5(1): 129-34.

281. Runnebaum IB, Tong XW, Konig R, Zhao H, Korner K, Atkinson EN, et al. p53based blood test for p53PIN3 and risk for sporadic ovarian cancer. Lancet. 1995; 345(8955): 994.

282. Campbell IG, Eccles DM, Dunn B, Davis M, Leake V. p53 polymorphism in ovarian and breast cancer. Lancet. 1996; 347(8998): 393-4.

283. Lancaster JM, Brownlee HA, Wiseman RW, Taylor J. p53 polymorphism in ovarian and bladder cancer. Lancet. 1995; 346(8968): 182.

284. Hao B, Miao X, Li Y, Zhang X, Sun T, Liang G, et al. A novel T-77C polymorphism in DNA repair gene XRCC1 contributes to diminished promoter activity and increased risk of non-small cell lung cancer. Oncogene. 2006; 25(25): 3613-20.

285. Hu Z, Ma H, Lu D, Zhou J, Chen Y, Xu L, et al. A promoter polymorphism ($77 \mathrm{~T}>\mathrm{C}$ ) of DNA repair gene XRCC1 is associated with risk of lung cancer in relation to tobacco smoking. Pharmacogenet Genomics. 2005; 15(7): 457-63.

286. Zhang X, Miao X, Liang G, Hao B, Wang Y, Tan W, et al. Polymorphisms in DNA base excision repair genes ADPRT and XRCC1 and risk of lung cancer. Cancer Res. 2005; 65(3): 722-6.

287. Vogel U, Nexo BA, Wallin H, Overvad K, Tjonneland A, Raaschou-Nielsen O. No association between base excision repair gene polymorphisms and risk of lung cancer. Biochem Genet. 2004; 42(11-12): 453-60. 
288. Divine KK, Gilliland FD, Crowell RE, Stidley CA, Bocklage TJ, Cook DL, et al. The XRCC1 399 glutamine allele is a risk factor for adenocarcinoma of the lung. Mutat Res. 2001; 461(4): 273-8.

289. Kiyohara C, Takayama K, Nakanishi Y. Association of genetic polymorphisms in the base excision repair pathway with lung cancer risk: a meta-analysis. Lung Cancer. 2006; 54(3): 267-83.

290. Ryk C, Kumar R, Thirumaran RK, Hou SM. Polymorphisms in the DNA repair genes XRCC1, APEX1, XRCC3 and NBS1, and the risk for lung cancer in neverand ever-smokers. Lung Cancer. 2006; 54(3): 285-92.

291. Wang ZH, Miao XP, Tan W, Zhang XR, Xu BH, Lin DX. [Single nucleotide polymorphisms in XRCC1 and clinical response to platin-based chemotherapy in advanced non-small cell lung cancer]. Ai Zheng. 2004; 23(8): 865-8.

292. Gurubhagavatula S, Liu G, Park S, Zhou W, Su L, Wain JC, et al. XPD and XRCC1 genetic polymorphisms are prognostic factors in advanced non-small-cell lung cancer patients treated with platinum chemotherapy. J Clin Oncol. 2004; 22(13): 2594-601.

293. Zhou W, Liu G, Miller DP, Thurston SW, Xu LL, Wain JC, et al. Polymorphisms in the DNA repair genes XRCC1 and ERCC2, smoking, and lung cancer risk. Cancer Epidemiol Biomarkers Prev. 2003; 12(4): 359-65.

294. Matullo G, Dunning AM, Guarrera S, Baynes C, Polidoro S, Garte S, et al. DNA repair polymorphisms and cancer risk in non-smokers in a cohort study. Carcinogenesis. 2006; 27(5): 997-1007.

295. Duell EJ, Millikan RC, Pittman GS, Winkel S, Lunn RM, Tse CK, et al. Polymorphisms in the DNA repair gene XRCC1 and breast cancer. Cancer Epidemiol Biomarkers Prev. 2001; 10(3): 217-22. 
296. Nexo BA, Vogel U, Olsen A, Ketelsen T, Bukowy Z, Thomsen BL, et al. A specific haplotype of single nucleotide polymorphisms on chromosome 19q13.23 encompassing the gene RAI is indicative of post-menopausal breast cancer before age 55. Carcinogenesis. 2003; 24(5): 899-904.

297. Schneider J, Classen V, Bernges U, Philipp M. XRCC1 polymorphism and lung cancer risk in relation to tobacco smoking. Int J Mol Med. 2005; 16(4): 709-16.

298. Shen M, Berndt SI, Rothman N, Mumford JL, He X, Yeager M, et al. Polymorphisms in the DNA base excision repair genes APEX1 and XRCC1 and lung cancer risk in Xuan Wei, China. Anticancer Res. 2005; 25(1B): 537-42.

299. Zienolddiny S, Campa D, Lind H, Ryberg D, Skaug V, Stangeland L, et al. Polymorphisms of DNA repair genes and risk of non-small cell lung cancer. Carcinogenesis. 2006; 27(3): 560-7.

300. Pachouri SS, Sobti RC, Kaur P, Singh J. Contrasting impact of DNA repair gene XRCC1 polymorphisms Arg399Gln and Arg194Trp on the risk of lung cancer in the north-Indian population. DNA Cell Biol. 2007; 26(3): 186-91.

301. Ratnasinghe D, Yao SX, Tangrea JA, Qiao YL, Andersen MR, Barrett MJ, et al. Polymorphisms of the DNA repair gene XRCC1 and lung cancer risk. Cancer Epidemiol Biomarkers Prev. 2001; 10(2): 119-23.

302. David-Beabes GL, London SJ. Genetic polymorphism of XRCC1 and lung cancer risk among African-Americans and Caucasians. Lung Cancer. 2001; 34(3): 333-9.

303. Chen S, Tang D, Xue K, Xu L, Ma G, Hsu Y, et al. DNA repair gene XRCC1 and XPD polymorphisms and risk of lung cancer in a Chinese population. Carcinogenesis. 2002; 23(8): 1321-5. 
304. Xing D, Qi J, Miao X, Lu W, Tan W, Lin D. Polymorphisms of DNA repair genes XRCC1 and XPD and their associations with risk of esophageal squamous cell carcinoma in a Chinese population. Int J Cancer. 2002; 100(5): 600-5.

305. Olshan AF, Watson MA, Weissler MC, Bell DA. XRCC1 polymorphisms and head and neck cancer. Cancer Lett. 2002; 178(2): 181-6.

306. Lee JM, Lee YC, Yang SY, Yang PW, Luh SP, Lee CJ, et al. Genetic polymorphisms of XRCC1 and risk of the esophageal cancer. Int J Cancer. 2001; 95(4): 240-6.

307. Varzim G, Monteiro E, Silva RA, Fernandes J, Lopes C. CYP1A1 and XRCC1 gene polymorphisms in SCC of the larynx. Eur J Cancer Prev. 2003; 12(6): 4959.

308. Yu HP, Zhang XY, Wang XL, Shi LY, Li YY, Li F, et al. DNA repair gene XRCC1 polymorphisms, smoking, and esophageal cancer risk. Cancer Detect Prev. 2004; 28(3): 194-9.

309. Stern MC, Umbach DM, van Gils CH, Lunn RM, Taylor JA. DNA repair gene XRCC1 polymorphisms, smoking, and bladder cancer risk. Cancer Epidemiol Biomarkers Prev. 2001; 10(2): 125-31.

310. Abdel-Rahman SZ, Soliman AS, Bondy ML, Omar S, El-Badawy SA, Khaled HM, et al. Inheritance of the 194Trp and the 399Gln variant alleles of the DNA repair gene XRCC1 are associated with increased risk of early-onset colorectal carcinoma in Egypt. Cancer Lett. 2000; 159(1): 79-86.

311. Thyagarajan B, Anderson KE, Folsom AR, Jacobs DR, Jr., Lynch CF, Bargaje A, et al. No association between XRCC1 and XRCC3 gene polymorphisms and breast cancer risk: Iowa Women's Health Study. Cancer Detect Prev. 2006; 30(4): 313-21. 
312. Patel AV, Calle EE, Pavluck AL, Feigelson HS, Thun MJ, Rodriguez C. A prospective study of XRCC1 (X-ray cross-complementing group 1) polymorphisms and breast cancer risk. Breast Cancer Res. 2005; 7(6): 1168-73.

313. Brewster AM, Jorgensen TJ, Ruczinski I, Huang HY, Hoffman S, Thuita L, et al. Polymorphisms of the DNA repair genes XPD (Lys751Gln) and XRCC1 (Arg399Gln and Arg194Trp): relationship to breast cancer risk and familial predisposition to breast cancer. Breast Cancer Res Treat. 2006; 95(1): 73-80.

314. Vogel U, Laros I, Jacobsen NR, Thomsen BL, Bak H, Olsen A, et al. Two regions in chromosome 19q13.2-3 are associated with risk of lung cancer. Mutat Res. 2004; 546(1-2): 65-74.

315. Yin J, Vogel U, Guo L, Ma Y, Wang H. Lack of association between DNA repair gene ERCC1 polymorphism and risk of lung cancer in a Chinese population. Cancer Genet Cytogenet. 2006; 164(1): 66-70.

316. Winsey SL, Haldar NA, Marsh HP, Bunce M, Marshall SE, Harris AL, et al. A variant within the DNA repair gene XRCC3 is associated with the development of melanoma skin cancer. Cancer Res. 2000; 60(20): 5612-6.

317. Chen P, Wiencke J, Aldape K, Kesler-Diaz A, Miike R, Kelsey K, et al. Association of an ERCC1 polymorphism with adult-onset glioma. Cancer Epidemiol Biomarkers Prev. 2000; 9(8): 843-7.

318. Shen M, Berndt SI, Rothman N, Demarini DM, Mumford JL, He X, et al. Polymorphisms in the DNA nucleotide excision repair genes and lung cancer risk in Xuan Wei, China. Int J Cancer. 2005; 116(5): 768-73.

319. Vogel U, Sorensen M, Hansen RD, Tjonneland A, Overvad K, Wallin H, et al. Gene-environment interactions between smoking and a haplotype of RAI, ASE-1 and ERCC1 polymorphisms among women in relation to risk of lung cancer in a population-based study. Cancer Lett. 2007; 247(1): 159-65. 